MARCOS LUIZ PAGLIARINI BREFE

\title{
Estudo sobre a integração entre design industrial e engenharia no processo de desenvolvimento de produtos em empresas brasileiras de pequeno porte
}

Dissertação apresentada à Escola de Engenharia de São Carlos, da Universidade de São Paulo, como parte dos requisitos para a obtenção do título de Mestre em Engenharia Mecânica.

Área de Concentração: Projeto Mecânico

Orientador: Prof. Dr. Jonas de Carvalho 
AUTORIZO A REPRODUÇÃO E DIVULGAÇÃO TOTAL OU PARCIAL DESTE TRABALHO, POR QUALQUER MEIO CONVENCIONAL OU ELETRÔNICO, PARA FINS DE ESTUDO E PESQUISA, DESDE QUE CITADA A FONTE.

Ficha catalográfica preparada pela Seção de Tratamento da Informação do Serviço de Biblioteca - EESC/USP

\begin{tabular}{|c|c|}
\hline \multirow[t]{3}{*}{ B832e } & $\begin{array}{l}\text { Brefe, Marcos Luiz Pagliarini } \\
\text { Estudo sobre a integração entre design industrial e } \\
\text { engenharia no processo de desenvolvimento de produtos em } \\
\text { empresas brasileiras de pequeno porte / Marcos Luiz } \\
\text { Pagliarini Brefe; orientador Jonas de Carvalho. -- São } \\
\text { Carlos, } 2008 \text {. }\end{array}$ \\
\hline & $\begin{array}{l}\text { Dissertação (Mestrado-Programa de Pós-Graduação em } \\
\text { Engenharia Mecânica e Área de Concentração: Projeto } \\
\text { Mecânico) -- Escola de Engenharia de São Carlos da } \\
\text { Universidade de São Paulo, } 2008 \text {. }\end{array}$ \\
\hline & $\begin{array}{l}\text { 1. Desenvolvimento do produto. } 2 \text {. Design industrial. } \\
\text { 3. Engenharia integrada. I. Titulo. }\end{array}$ \\
\hline
\end{tabular}




\section{FOLHA DE JULGAMENTO}

\section{Candidato: Licenciado MARCOS LUIZ PAGLIARINI BREFE}

Dissertação defendida e julgada em 30/06/2008 perante a Comissão Julgadora:
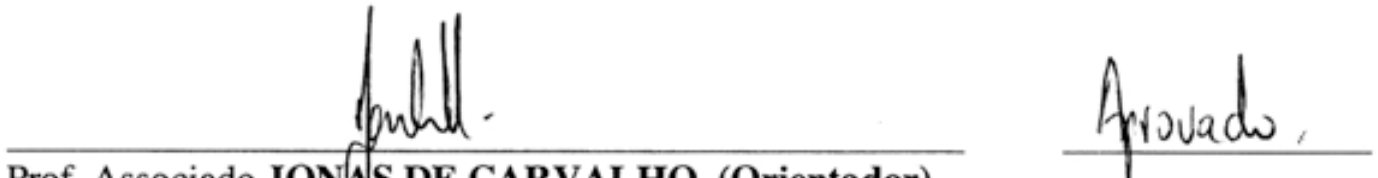

Prof. Associado JONAS DE CARVALHO (Orientador)

(Escola de Engenharia/de São Carlos/USP)
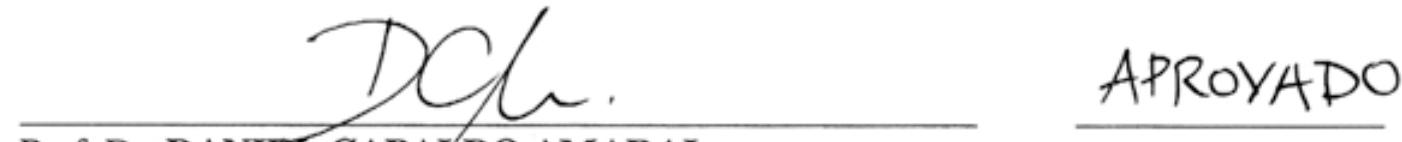

Prof. Dr. DANIEL CAPALDO AMARAL

(Escola de Engenharia dé São Carlos/USP)

Civiteo Nualoguli

Prof . Dr". CYNTIA SANTOS MALAGUTTI DE SOUZA

Apraado

(Centro Universitário Belas Artes)

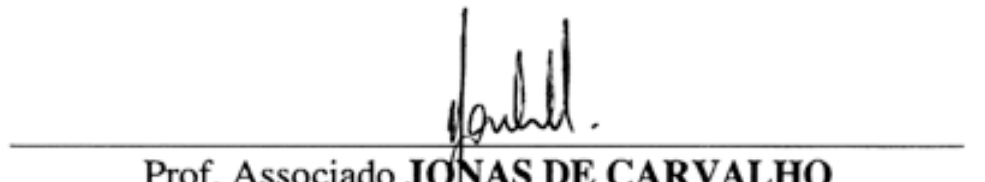

Prof. Associado JONAS DE CARVALHO

Coordenador do Programa de Pós-Graduação em

Engenharia Mecânica

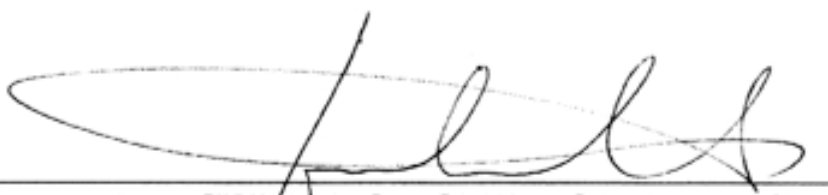

Prof. Associado GERALDO ROBERTO MARTINS DA COSTA

Presidente da Comissão da Pós-Graduação da EESC 
Dedico este trabalho à minha esposa $\mathrm{e}$ ao meu filho. Além de motivadores primordiais deste trabalho, compreenderam minhas longas horas de ausência como marido e pai, dedicadas à realização deste esforço científico. 


\section{AGRADECIMENTOS}

Ao Prof. Dr. Jonas de Carvalho, meu orientador, pela coragem e visão de apoiar um estudo sobre design industrial em um departamento de engenharia e pela orientação, paciência e confiança despendidas.

À Fundação Parqtec e seus dirigentes, pelo apoio e incentivo à realização deste trabalho. Aos designers e engenheiros do Instituto Parqtec de Design, do Núcleo de Engenharia e Prototipagem do Parqtec e das empresas que mantive contato, pelo acompanhamento, incentivo, contribuição e participação direta ou indireta neste trabalho.

Ao Prof. Dr. Carlos Alberto Fortulan, que sempre me incentivou a sistematizar o conhecimento, e ao Dr. João Morais da Silva Neto, um dos engenheiros de espírito mais aberto que já conheci.

Aos meus pais, irmãs, familiares e amigos, que sempre incentivaram meus questionamentos e ouviram minhas intermináveis elucubrações sobre o assunto. 
"Opposition by engineers to employing industrial designers is evidently fairly widespread. Because engineers have a central role in technological innovation, their attitude towards industrial design is crucial. There is cause for concern if the progress of technological innovation is impeded by the prejudice of engineers.” - Stanley Moody 


\section{RESUMO}

BREFE, M.L.P. (2008). Estudo sobre a integração entre design industrial e engenharia no processo de desenvolvimento de produtos em empresas brasileiras de pequeno porte. São Carlos, 2008. 202 p. Dissertação (Mestrado) - Escola de Engenharia de São Carlos, Universidade de São Paulo.

Existe uma comprovada correlação positiva entre a utilização de design e o desempenho comercial das empresas. Portanto, é desejável que o design industrial seja integrado à engenharia no processo de desenvolvimento de produtos (PDP). Este trabalho investiga a integração entre design industrial e engenharia no PDP, com ênfase em empresas brasileiras de pequeno porte, pois existem evidências de negligência desta abordagem integradora e dificuldades práticas, uma vez optado pela integração. Foram propostos um framework, que buscou estabelecer as classes de fatores ou dimensões que podem ter alguma influência no fenômeno, e um conjunto de "Boas Práticas", que pudesse ser utilizado como parâmetro comparativo para a realidade e para a aplicação prática em estudos de caso. Também foram levantados, na revisão bibliográfica, e utilizados um "Modelo de Maturidade de Design" e uma "Ferramenta de Auditoria do Produto". A pesquisa de campo, do tipo pesquisa-ação, utilizou uma amostra de 180 empresas e 10 estudos de caso em profundidade, envolvendo visitas às empresas, entrevistas com empresários e participantes do processo de desenvolvimento, análise documental e participação ativa em casos reais de desenvolvimento de produtos. Os resultados demonstram que a grande maioria das empresas de pequeno porte brasileiras situa-se nos dois níveis mais baixos, entre os quatro possíveis, do modelo de maturidade, o que é uma situação indesejável. A distribuição das empresas de base tecnológica é muito semelhante, o que torna ainda mais preocupante o quadro, pois este tipo de empresa é considerado um instrumento para transformação de conhecimento em riqueza. Os estudos de caso de desenvolvimento de produtos, com ênfase na integração precoce do design industrial à engenharia no PDP, permitem afirmar que os produtos desenvolvidos desta forma tendem a obter melhor desempenho tanto na performance técnica quanto de interface, o que potencialmente melhora suas chances de competição no mercado atual. Foram identificados benefícios e barreiras, adaptações nas "Boas Práticas" propostas para sua aplicação nas especificidades das pequenas empresas e implicações da situação observada.

Palavras-Chave: Desenvolvimento de Produto. Design Industrial. Engenharia Integrada 


\begin{abstract}
BREFE, M.L.P. (2008). Study of the integration between industrial design and engineering design in product development process on Brazilian small businesses. São Carlos, 2008. 202 p. Dissertation (Master Degree) - Escola de Engenharia de São Carlos, Universidade de São Paulo.
\end{abstract}

There is a proved positive correlation between design use and business performance. Therefore, it is desirable to integrate industrial design to engineering design in product development process (PDP). This study investigates the integration between industrial design and engineering design in PDP, giving emphasis on Brazilian small businesses. There is evidence about the neglect of this integrated approach and difficulties in practice. It has been proposed a framework - trying to stablish the classes of factors or dimensions that have influence on the phenomenon - and a set of "Best Practices" - to use as a comparative parameter to empirical data and to pratical aplication on case studies. Also, it has been used a "Design Maturity Model" and a "Product Audit Tool", based on the literature review. The field research - action-research type - used a sample of 180 companies and 10 case studies, involving visit to businesses, interviews with business owners and product development process participants, documental analysis and active participation on real cases of product development. The results show that most of Brazilian small businesses take place on the two lower levels, among four possible, what is an undesirable situation. The technology-based business distribution on the model is very similar, becoming more concerning this situation, because this kind of enterprise is considered as an instrument to transform knowledge in wealth. The product development case studies with emphasis on early integration of industrial design in the PDP allow to state that products that were developed with this approach tend to gain better results on both technical and human interface performance, what potentially improve the chances to compete in actual market. It was identified benefits and barries, adaptations in proposed "Best Practices" for aplication on small businesses and consequences of the observed situation.

Keywords: Product Development. Industrial Design. Integrated Engineering. 


\section{LISTA DE FIGURAS}

Figura 2.1 - Desempenho de empresas que investem em design vs. empresas em geral...... 45

Figura 2.2 - O "produto ampliado".

Figura 2.3 - Exemplos de diagramas para estudo e adaptação da ergonomia física...........67

Figura 2.4 - Exemplos ilustrativos relacionados à ergonomia cognitiva...............................68

Figura 2.5 - Exemplo ilustrativo de um "quadro de estilo de vida" ...............................68

Figura 2.6 - Visão geral / Modelo de Referência do PDP....................................................72

Figura 2.7 - Visão genérica do New Product Development - IfM........................................76

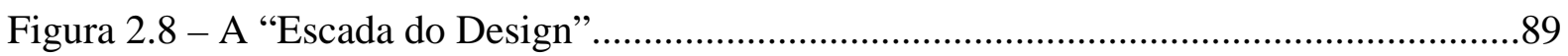

Figura 2.9 - Distribuição das empresas dinamarquesas na "Escada do Design”...................90

Figura 2.10 - Distribuição das empresas dinamarquesas na "Escada do Design" de acordo com o porte.........................................................................

Figura 2.11 - Distribuição das empresas austríacas na "Escada do Design" em relação às

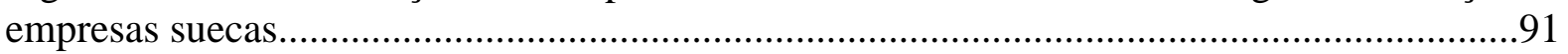

Figura 2.12 - Duas culturas: departamento de design (à direita) e departamento de engenharia de indústria automobilística.

Figura 2.13 - Exemplos de sketches de projeto reais que expressam "pensamento visual" e

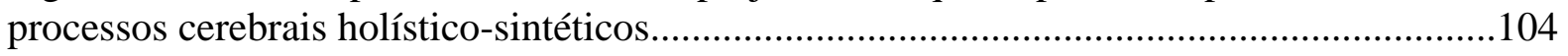

Figura 2.14 - Exemplos técnicas de projeto típicas da engenharia.........................106

Figura 2.15 - Exemplos de técnicas de projeto típicas do design industrial.................106

Figura 2.16 - "Lógica invertida" dos designers e engenheiros............................................109

Figura 2.17 - Representação gráfica dos processos de pensamento e lados do cérebro......109

Figura 3.1 - Framework proposto para o estudo do fenômeno da integração entre engenharia e

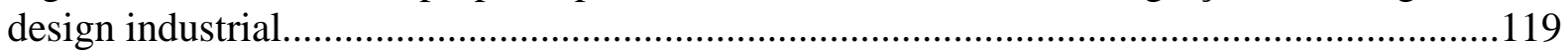

Figura 3.2 - Representação do nível de maturidade de design vs. à fase do PDP............122

Figura 3.3 - Programa do Mech-E/MIT para integração do design..........................134

Figura 4.1 - Tentativa de representação gráfica da dinâmica do framework observada.......167

Figura 4.2 - Representação gráfica da aplicação das "Boas Práticas" ao PDP................173 


\section{LISTA DE TABELAS}

Tabela 4.1 - Distribuição das empresas da amostra no modelo de "Maturidade de

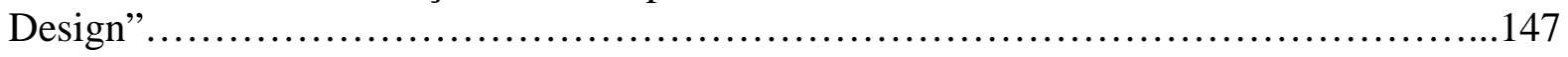

Tabela 4.2 - Comparativo da distribuição da amostra com estudos similares.................149

Tabela 4.3 - "Auditoria do Produto" nos produtos das empresas do Nível II - projetos

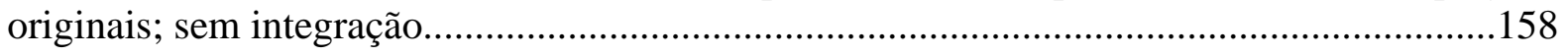

Tabela 4.4 - "Auditoria do Produto" nos produtos das empresas do Nível II após novo PDP com integração precoce do design industrial............................................ 158

Tabela 4.5 - "Auditoria do Produto" nos produtos das empresas do Nível III - projeto desenvolvidos com integração precoce do design originalmente.........................159 


\section{LISTA DE QUADROS}

Quadro 1.1 - Modelo de "Maturidade de Design"

Quadro 1.2 - Dimensões-chave para avaliação da performance. .30

Quadro 1.3 - Importância para os usuários/consumidores.................................32

Quadro 1.4 - Quadro da dimensão Qualidade de Engenharia.................................33

Quadro 1.5 - Quadro de compilação final............................................ 34

Quadro 1.6 - Correlação entre as dimensões da ferramenta e as macro-dimensões...............36

Quadro 2.1 - Modelo de "Maturidade de Design"...............................................................8

Quadro 2.2 - Diferenças entre ciência, tecnologia e design..............................108

Quadro 2.3 - Fases do PDP e respectivos problemas comuns............................114

Quadro 3.1 - Conjunto de "Boas Práticas” inferidas das referências ..........................144

Quadro 4.1 - Características de entorno dos projetos de produto selecionados...............155

Quadro 4.2 - Seleção de empresas/produtos de base tecnológica..............................155 


\section{SUMÁRIO}

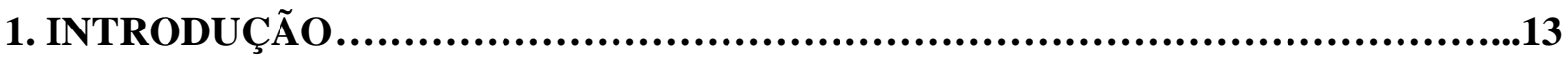

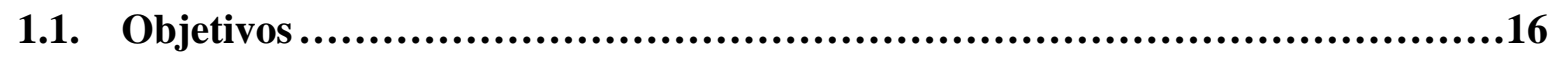

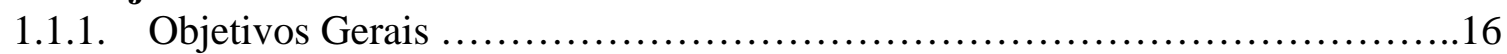

1.1.2. Objetivos Específicos ................................................. 16

1.2. Método ......................................................................17

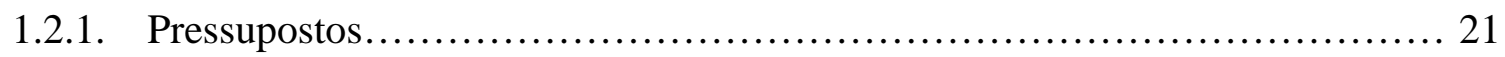

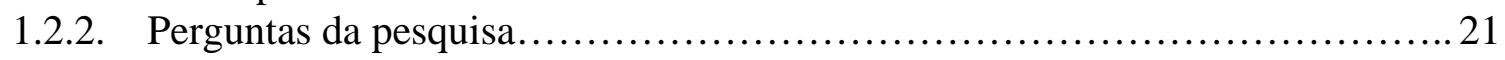

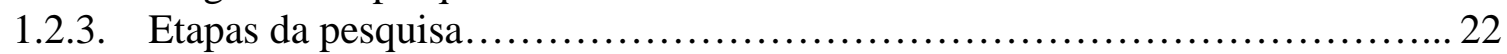

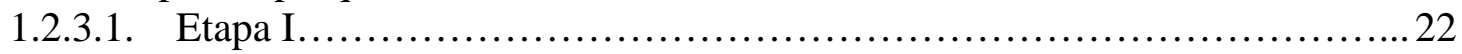

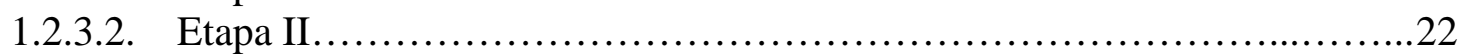

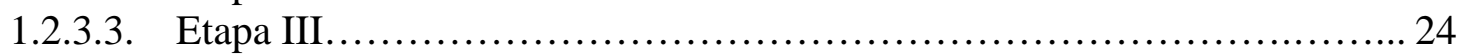

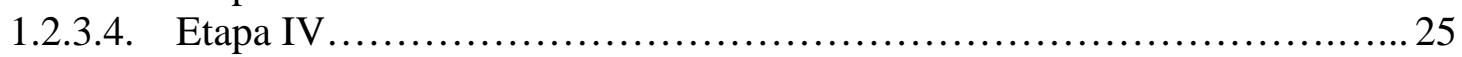

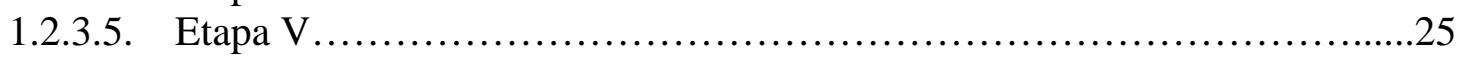

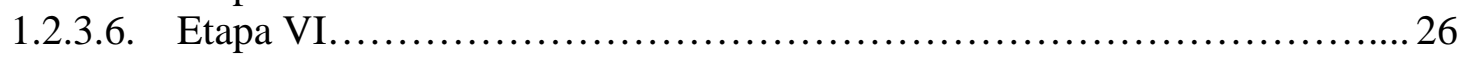

1.2.4. "Ferramenta de Auditoria do Produto"...................................... 27

1.2.4.1. Descrição da "Ferramenta de Auditoria do Produto"........................ 27

1.2.4.2. A visão do usuário sobre qualidade do produto......................... 28

1.2.4.3. A visão da empresa sobre qualidade do produto...........................29

1.2.4.4. Aplicação................................................................ 30

1.2.4.5. Pontuação........................................................ 31

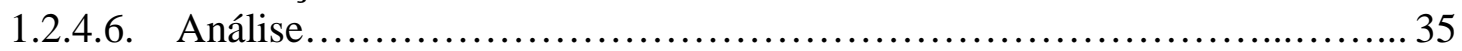

1.2.5. Materiais e instalações.................................................. 37

1.3. Estrutura do Trabalho............................................................... 38

2. REVISÃO BIBLIOGRÁFICA E FUNDAMENTAÇÃO TEÓRICA ..................41

2.1. Fundamentos do Design e da Engenharia para a Competitividade............. 41

2.1.1. A importância internacional do design...................................... 42

2.1.1.1. Estudos sobre a eficácia do design para a competitividade................. 44

2.1.2. Performance técnica e performance de interface.............................. 49

2.1.2.1. O conceito de "Bom Design"..........................................54

2.1.3. Dois tipos de design: engineering design e industrial design.................... 57

2.1.3.1. Aspectos relacionados ao design industrial no projeto de produtos.........6 63

2.1.4. Processo de Desenvolvimento de Produtos (PDP)......................... 70

2.2. Contornos do Fenômeno da Integração entre Design e Engenharia............. 77

2.2.1. As especificidades das pequenas empresas................................. 79

2.2.1.1. Utilização do design na perspectiva de um modelo de maturidade............ 85

2.2.1.2. As empresas de pequeno porte no Brasil........................... 92

2.2.2. Problemas e limitações inerentes ao PDP.................................. 93

2.2.3. A lacuna cultural entre engenheiros e designers...............................95

2.2.3.1. Delineando a lacuna cultural........................................... 98

2.2.3.2. Diferenças na natureza dos problemas e objetivos de projeto...............99

2.2.3.3. Diferenças nas metodologias e técnicas de projeto.........................101

2.2.3.4. Diferenças nos critérios de aprovação e indicadores de sucesso .............107 
2.2.3.5. Diferenças psico-fisiológicas e cognitivas.............................. 108

2.2.3.6. Consequências gerais ...............................................110

\section{PROPOSTAS PARA O ESTUDO E A PRÁTICA: FRAMEWORK E "BOAS}

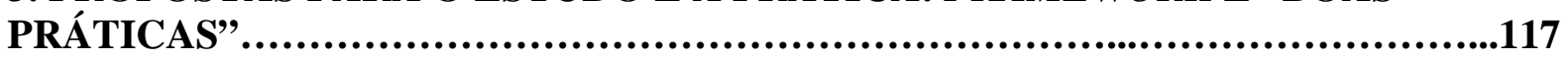

3.1. Framework para estudo do fenômeno da integração design e engenharia ......118

3.2. "Boa Prática" Primária - Integração Precoce ...................................119

3.3. "Boas Práticas" Secundárias ...............................................123

3.3.1. IDEO ................................................................ 124

3.3.2. Apple ................................................................ 127

3.3.3. Philips ................................................................. 130

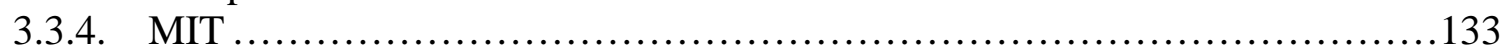

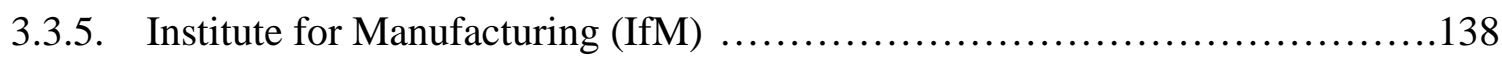

3.3.5.1. Princípios orientadores do bom (processo de) design .................... 139

3.4. Conjunto de "Boas Práticas" ............................................142

4. APRESENTAÇÃO E ANÁLISE DOS RESULTADOS............................145

4.1. Empresas de pequeno porte em relação ao modelo de Maturidade de Design 146

4.1.1. Observações qualitativas em relação à "Maturidade de Design" da amostra....151

4.2. Estudos de Caso .................................................................153

4.2.1. Aplicação da "Ferramenta de Auditoria do Produto" ..........................156

4.2.2. Novo desenvolvimento de produtos para as empresas do Nível II .............156

4.2.3. Desenvolvimento de produtos para as empresas do Nível III ..................159

4.2.4. Considerações qualitativas sobre os estudos de caso.........................159

4.3. Observações através da perspectiva do framework proposto $\ldots . . \ldots \ldots \ldots . . . \ldots . . .163$

4.4. Análise dos resultados na perspectiva das perguntas de pesquisa $\ldots . . \ldots \ldots \ldots . . .168$

4.4.1. Sobre a integração precoce do design à engenharia no PDP ...................168

4.4.2. Sobre os benefícios potenciais da integração precoce para a competitividade..168

4.4.3. Sobre as barreiras para a integração precoce do design ao PDP.................169

4.4.4. Sobre a implicações das barreiras ao PDP das empresas e a competitividade ..173

5. CONSIDERAÇÕES FINAIS

5.1. Implicações para a teoria, prática e limitações

REFERÊNCIAS BIBLIOGRÁFICAS

ANEXO A - IMAGENS DOS ESTUDOS DE CASO ......................................................191

APÊNDICE A - PLANILHAS "FERRAMENTA DE AUDITORIA DO PRODUTO" 195 



\section{INTRODUÇÃO}

A competição atual entre as empresas depende, em grande parte, da sua capacidade de desenvolvimento de produtos, resultando numa tendência à concentração das atividades relacionadas ao projeto e sua gestão e ao deslocamento da produção para qualquer ponto do globo que ofereça melhores condições e vantagens. No paradigma da Produção em Massa, em última instância, o objetivo era produzir os produtos com o menor custo possível de forma que quase todos pudessem adquiri-lo e, assim, retro-alimentar um sistema baseado na economia de escala. No paradigma da Customização Maciça, que vem substituindo o anterior, o objetivo é ter flexibilização produtiva de tal ordem que permita um nível de variedade e personalização para que a maior parte dos consumidores encontrem exatamente aquilo que desejam.

Neste cenário, que promove a personalização e, portanto, a segmentação, é essencial desenvolver produtos que atendam adequadamente às necessidades específicas de grupos de consumidores. Um aspecto relevante - tanto mais quanto mais íntima a relação produtousuário - é o deslocamento da avaliação dos produtos pelos consumidores para os atributos mais intangíveis, o que pressupõe a satisfação de necessidades - e desejos - que vão além da solução técnica que o produto proporciona. Uma ampla gama de produtos com tecnologia, qualidade e desempenho técnico similares nas diversas faixas de preço possíveis, permite que os consumidores possam escolher com maior liberdade de forma a satisfazer suas necessidades psicológicas, desejos e aspirações de cunho social com motivações variadas algumas, inclusive, latentes e/ou desconhecidas. Observa-se, assim, a necessidade da participação de diferentes "tipos de design" no desenvolvimento de produtos, especialmente o engineering design - engenharia de produto, ou, simplesmente, engenharia - e o industrial design - design industrial, ou, simplesmente, design - como são internacionalmente 
conhecidos. Ambas as áreas são dedicadas ao projeto de produtos, porém, através de perspectivas diferentes, como será explorado ao longo deste trabalho.

Uma vez que o projeto das características dos produtos relacionadas à sua interface com os seres humanos nos níveis funcionais, estético e simbólico é o objeto de estudo e prática do design industrial, é essencial que as empresas o incorporem ao seu processo de desenvolvimento de produtos, tradicionalmente orientado de forma predominante pelas engenharias. Estudos acadêmicos e a observação das práticas de empresas de sucesso permitem afirmar com razoável segurança que os fabricantes de produtos destinados ao consumo de maior sucesso da atualidade, mais do que desenvolver e embarcar tecnologia, se preocupam em como disponibilizar esta tecnologia adequadamente para os seres humanos usuários e consumidores, adaptando-os tanto às suas necessidades físicas quanto psicológicas e sociais. A competição se desloca em grande parte da tecnologia para a qualidade da interface desta para com os seres humanos. Ignorar este fato dificulta as chances de sucesso comercial das empresas, bem como das aspirações de qualquer nação que tenha como meta transformar conhecimento em tecnologia e esta em produtos comercializados com sucesso no mercado global, fechando o ciclo da inovação.

Este trabalho busca investigar a integração entre o design industrial e engenharia no processo de desenvolvimento de produtos (PDP), com ênfase em identificar a situação atual deste tipo de prática em empresas brasileiras de pequeno porte. Existem evidências na literatura indicando que as empresas deste porte, mundialmente, têm dificuldade em integrar o design industrial ao seu PDP, bem como existem evidências sobre grandes dificuldades práticas na adoção deste tipo de abordagem integradora nas empresas brasileiras de pequeno porte. A despeito disto, há uma carência de literatura relacionada. 
O tema surgiu a partir do trabalho de projeto de produtos para micro e pequenas empresas desenvolvido pelo pesquisador no Instituto Parqtec de Design e no Núcleo de Engenharia e Prototipagem Rápida, ambos da Fundação Parque de Alta Tecnologia São Carlos. Com o objetivo de oferecer às empresas nascentes suporte para o desenvolvimento de produtos mais competitivos, desenvolveu-se metodologia para inserção do design industrial nos empreendimentos brasileiros, baseando-se nas premissas de que o design industrial é essencial para a competitividade dos produtos na atualidade e que este tipo de abordagem ainda é deficiente no Brasil - conforme diagnosticado pelo Programa Brasileiro de Design e Sebrae. A prática, desde 1999, com centenas de atendimentos às pequenas empresas, vários diagnósticos e algumas dezenas de produtos desenvolvidos, fornece evidências que apontam para deficiências na integração entre a engenharia de produto e o design industrial, com o desenvolvimento de produtos realizado essencialmente pela ótica das engenharias, a negligência ou ignorância da importância da interface dos produtos com os usuários nos âmbitos físico e psicológico, a falta de diálogo entre engenheiros e designers industriais, entre outros aspectos.

Este trabalho é ambicioso, pois ao mesmo tempo em que se propõe a investigar se o design industrial está sendo integrado adequadamente à engenharia nas empresas de brasileiras de pequeno porte, o faz através da proposição de um framework para o estudo deste tipo de fenômeno e da aplicação de "Boas Práticas" em estudos de caso. De forma similar, os estudos de caso são utilizados tanto como base para uma investigação de natureza descritiva - no sentido de utilizar parâmetros desejáveis e confrontá-los com a situação atual quanto com o objetivo de demonstrar as barreiras, as vantagens e a viabilidade da integração entre design e engenharia na realidade das empresas de pequeno porte brasileiras, tendo assim certa natureza prescritiva. Estes aspectos estão em consonância com a sua natureza exploratória. 
Espera-se que este estudo tenha impacto positivo na academia, estimulando os departamentos de engenharia a abrirem suas portas para a integração com o design industrial, à semelhança dos seus equivalentes internacionais. Também espera-se que tenha impacto no setor produtivo, seja fornecendo ferramentas para a compreensão e modificação da realidade nas empresas, seja ampliando a pouca discussão sobre o assunto no Brasil, essencial para a competitividade das empresas.

Especialmente, espera-se trazer o assunto à luz através da perspectiva das empresas de pequeno porte, que representam aproximadamente $98 \%$ das empresas constituídas e $67 \%$ dos postos de trabalho no setor privado no Brasil e, apesar da sua importância cabal para a saúde da economia nacional, enfrentam dificuldades específicas deste porte de empresa e carecem de estudos e ferramentas adequadas para a sua realidade.

\subsection{OBJETIVOS}

\subsubsection{Objetivos Gerais}

Propor, baseado na literatura e no estudo do PDP de empresas de referência, um conjunto de "Boas Práticas" para a integração do design industrial à engenharia no processo de desenvolvimento de produtos e aplicá-las em estudos de caso oriundos de empresas brasileiras de pequeno porte, de forma a obter evidências sobre possíveis disfunções na integração e, ao mesmo tempo, observar a sua aplicabilidade nas condições específicas deste porte de empresa.

\subsubsection{Objetivos Específicos}

Estabelecer pressupostos, baseados na revisão da literatura, que fundamentem a importância de estudar o assunto e a sua dinâmica geral; 
- $\quad$ Propor um framework que permita orientar esta investigação exploratória e ser aprimorado em trabalhos futuros;

Identificar e utilizar ferramentas mais robustas para a investigação de fenômenos ligados à área de design industrial;

Avaliar os resultados na perspectiva das perguntas de pesquisa, das "Boas Práticas" propostas e do framework proposto, de forma a construir um panorama da situação atual do fenômeno nas empresas de pequeno porte e suas implicações para a teoria e a prática, de forma a servir de base mais robusta para o desenvolvimento de trabalhos futuros.

\subsection{MÉTODO}

Esta introdução descreve as questões gerais em relação à natureza deste trabalho, tipo de pesquisa e outros aspectos relacionados, bem como medidas tomadas para lidar com as limitações e riscos inerentes.

O objetivo último deste estudo é similar ao exposto por SELLTIZ et. al. (1974, p.59) na sua proposta de quatro agrupamentos de objetivos de pesquisa: "familiarizar-se com o fenômeno ou conseguir nova compreensão deste, frequentemente para poder formular um problema mais preciso de pesquisa ou criar novas hipóteses". Este tipo de estudo é normalmente denominado exploratório.

Os estudos exploratórios têm por objetivo buscar maiores informações sobre determinado assunto de estudo, geralmente pouco explorado e conhecido, visando, em última instância, permitir um maior conhecimento para a formulação de hipóteses frutíferas para estudos mais aprofundados (CERVO e BERVIAN, 1996); proporcionar maior familiaridade 
com o problema, com vistas a torná-lo mais explícito ou permitir construir hipóteses (GIL, 1991).

A abordagem predominante neste tipo de estudo é qualitativa, embora não exclua a quantitativa. Os métodos qualitativos e quantitativos são estratégias alternativas e possuem vantagens e fraquezas, mas não são excludentes. STRAUSS e CORBIN (1990) colocam que a pesquisa qualitativa denomina pesquisas cujos resultados não foram obtidos através de procedimentos estatísticos ou outros meios de quantificação; alguns dados podem ser quantificados, mas a análise propriamente dita é qualitativa. Este estudo tem abordagem predominantemente qualitativa, mas busca utilizar métodos quantitativos onde pertinente, como forma de completar, enriquecer e robustecer a análise qualitativa, sem descaracterizar a profundidade e a riqueza de detalhes que esta abordagem oferece.

Segundo GIL (1991) a pesquisa exploratória pode envolver um levantamento bibliográfico, entrevistas com pessoas que tiveram experiências práticas com o problema pesquisado e análise de exemplos que estimulem a compreensão do problema. Este estudo utiliza-se de um levantamento bibliográfico, da construção de um referencial teórico, de entrevistas com participantes de processos de desenvolvimento de produto e de análise de casos reais de desenvolvimento de produtos.

Segundo YIN (1981), o estudo de caso se caracteriza como sendo uma estratégia de pesquisa, que busca examinar um fenômeno contemporâneo dentro do seu contexto. Coloca ainda (YIN, 1994, p.10) que estudos de caso, enquanto experimentos, são generalizáveis para proposições teóricas e não para populações e universos". Pode, segundo STAKE (1994), ser realizado na forma de um estudo único ou múltiplo. No caso desta pesquisa foram realizados estudos de caso múltiplos. Concorda-se com STAKE (1994, p.237) sobre estudos de caso 
coletivos “[...] onde pesquisadores podem estudar um número de casos conjugadamente de forma a obter informações sobre o fenômeno, população ou condição geral”.

YIN (1994) coloca que, em relação à lógica da ligação dos dados às proposições e os critérios para interpretação dos resultados, isto é, o que deve ser feito depois da coleta de dados, o atual estado-da-arte ainda não oferece detalhamentos a respeito dos procedimentos a serem adotados. Conforme descrito nas seções subseqüentes deste capítulo, foram utilizadas ferramentas para permitir uma análise e interpretação dos dados mais robusta, como a proposta original de um framework - com as classes ou dimensões que influenciar no fenômeno da integração do design à engenharia no PDP - e um conjunto de "Boas Práticas", bem como a utilização de um modelo de "Maturidade de Design" ( do tipo "Escada do Design") e uma "Ferramenta de Auditoria do Produto", ferramentas levantadas na literatura e utilizadas para a interpretação dos dados. Os estudos de caso foram selecionados, tanto quanto possível, de forma a homogeneizar o máximo possível as condições de contorno, motivo pelo qual foram selecionados produtos de empresas de base tecnológica de porte pequeno e com características similares quanto ao tipo de interação entre design e engenharia, equipe das empresas, região, entre outros aspectos.

O estudo de caso permite a obtenção de informações de diversas maneiras, seja através do exame de registros existentes, entrevistas, observação participante ou de alguma outra abordagem (SELLTIZ et. al., 1974). Este trabalho se utilizou de todas as maneiras citadas, com o pesquisador tendo estreita convivência com o grupo estudado e com intensa observação da unidade de estudo, inclusive interferindo, no caso da aplicação de "Boas Práticas", com objetivo explícito de avaliar o impacto no fenômeno para análise comparativa.

As limitações e riscos estão relacionados às próprias limitações dos métodos empregados e da estratégia de pesquisa adotada, como a dependência do pesquisador na 
captação e interpretação dos resultados, a dificuldade em realizar generalizações, a possibilidade de abandono do ideal científico, a possibilidade de influência nos entrevistados e participantes, a parcialidade, a subjetividade na interpretação dos dados, entre outros. Esta limitações e riscos foram considerados desde o início e buscou-se compensar com objetividade e rigor científico, bem como a adoção de diversas ferramentas conceituais e práticas que permitissem minimizar as desvantagens e riscos e maximizar as vantagens do tipo de estudo escolhido. Buscou-se uma revisão bibliográfica que definisse de forma clara e precisa os termos e a construção de um referencial teórico apropriado que delineasse os contornos do fenômeno e oferecesse um arcabouço para suportar melhor a generalização. Buscou-se construir, na falta de um referencial mais robusto e claro, um framework original que orientasse a investigação. Buscou-se conjugar a observação participante com entrevistas mais formais. Buscou-se classificar as empresas através de um modelo de maturidade levantado na literatura, aplicado em pesquisas por grupos independentes e em diversas condições de contorno. Buscou-se avaliar os resultados mais subjetivos do desenvolvimento de produto com uma ferramenta mais quantitativa.

Finalmente, ciente das limitações deste trabalho, espera-se que os resultados atingidos, bem como o processo utilizado, possam ser utilizados como base inicial para pesquisas futuras mais delimitadas e que possam estabelecer correlações mais precisas entre as dimensões que influenciam o fenômeno em questão. Assim sendo, o objetivo desta pesquisa exploratória terá obtido êxito.

A seguir são detalhados os pressupostos, as perguntas e etapas de pesquisa e ferramentas analíticas utilizadas. 


\subsubsection{Pressupostos}

(1) Existe uma correlação positiva entre a utilização de design industrial e o desempenho comercial e financeiro das empresas.

(2) Os produtos precisam conciliar performance técnica e performance de interface para competir adequadamente nas características do mercado atual.

(3) A engenharia é responsável pelo projeto das características relacionadas à performance técnica e o design industrial pelas características de performance de interface dos produtos.

(4) O processo de desenvolvimento de produtos deve integrar a engenharia e o design industrial, além das outras as áreas do conhecimento tradicionalmente envolvidas.

\subsubsection{Perguntas da pesquisa}

(1) A integração precoce entre design industrial e engenharia de produto ocorre nas empresas de base tecnológica brasileiras?

(2) A integração precoce entre design industrial e engenharia de produto pode trazer benefícios (potencialmente) para a competitividade dos produtos desenvolvidos?

(3) Quais são possíveis as barreiras para que esta integração ocorra?

(4) Quais as implicações destas barreiras para o PDP das empresas e sua competitividade? 


\subsubsection{Etapas da pesquisa}

\subsubsection{Etapa I}

Compilação de informações que indiquem a dinâmica das empresas de pequeno porte em relação ao PDP e à integração entre design industrial e engenharia.

Objetivos: vislumbrar os problemas comuns às empresas de pequeno porte na realidade do PDP no Brasil, de forma a relacioná-los com as "Boas Práticas" propostas e adaptá-las para melhor desempenho no PDP, integrando design e engenharia.

Técnicas de coleta e análise de dados: entrevistas e visitas às empresas; acompanhamento do PDP, através da observação presencial em reuniões, atuação no processo, análise documental e entrevistas com os participantes.

\subsubsection{Etapa II}

Classificação de amostra de empresas através de um modelo de "Maturidade de Design", com base nos aspectos observados (ex.: estágio do desenvolvimento de produto que procuram a contribuição do design industrial) e as características esperadas em cada nível do modelo.

A amostra será obtida a partir das empresas contactadas nas atividades do Núcleo de Design Industrial e do Núcleo de Engenharia e Prototipagem Rápida, ambos do Parqtec São Carlos. A amostra, portanto, não será estratificada de acordo com as proporções observadas no universo geral de empresas em relação ao porte, setor, segmento etc. A classificação quanto ao porte será feita a partir do critério operacional utilizado pelo SEBRAE (1991): micro e pequenas empresas (MPEs) são estabelecimentos com até 49 empregados no comércio e serviços e com até 99 empregados na indústria; estabelecimentos com 50 ou mais empregados no comércio e serviços e com 100 ou mais na indústria são considerados médias 
e grandes empresas (MGEs). As micro e pequenas empresas serão chamadas neste trabalho de empresas de pequeno porte (EPPs).

Objetivos: identificar em qual estágio do PDP as empresas mais procuram a contribuição do design industrial, entre outras características. Esta informação pode ser utilizada para análises sobre o estágio de maturidade das empresas em relação à inserção do design industrial e sua preparação para a competitividade no mercado atual, considerando que o estágio em que procura este tipo de serviço é um reflexo da sua cultura, estratégia, compreensão e visão em relação à sua importância para o PDP e para a empresa. Paralelamente, podem ser observados outros aspectos, através das entrevistas semiestruturadas, como: porte, mercado, características do staff de desenvolvimento de produtos, utilização de pesquisas com usuários, orientação market pull ou technology push etc.

Técnicas de coleta e análise de dados: análise documental dos formulários e entrevistas semi-estruturadas preenchidas pela equipe da instituição.

A classificação em relação ao estágio se baseará no modelo de maturidade exposto no Quadro 1.1.

Quadro 1.1 - Modelo de "Maturidade de Design"

\begin{tabular}{|c|c|c|c|}
\hline Nível I & Nível II & Nível III & Nível IV \\
\hline $\begin{array}{c}\text { Design } \\
\text { Silencioso }\end{array}$ & $\begin{array}{c}\text { Maquiagem } \\
\text { de Produto }\end{array}$ & $\begin{array}{c}\text { Inovação Orientada } \\
\text { pelo Design }\end{array}$ & $\begin{array}{c}\text { Design } \\
\text { Estratégico }\end{array}$ \\
\hline $\begin{array}{c}\text { Designers são vistos } \\
\text { como caros e não- } \\
\text { práticos. Estética não é } \\
\text { percebida como } \\
\text { importante e/ou a } \\
\text { aparência dos produtos é } \\
\text { tipicamente } \\
\text { desenvolvida por } \\
\text { engenheiros ou outros } \\
\text { profissionais não- } \\
\text { especializados. }\end{array}$ & $\begin{array}{c}\text { A expertise de designers são } \\
\text { profissionais é útil em } \\
\text { alguns projetos, mas } \\
\text { primordialmente } \\
\text { utilizada para "maquiar" } \\
\text { o produto. }\end{array}$ & $\begin{array}{c}\text { Designers profissionais } \\
\text { são elementos-chave } \\
\text { para a inovação e } \\
\text { sempre participam desde } \\
\text { o estágio da idéia. }\end{array}$ & $\begin{array}{c}\text { propulsores essenciais } \\
\text { da inovação e } \\
\text { participam desde o } \\
\text { estágio de pré-projeto. } \\
\text { Design é uma peça } \\
\text { fundamental da cultura } \\
\text { organizacional. }\end{array}$ \\
\hline
\end{tabular}




\subsubsection{Etapa III}

Seleção de produtos de base tecnológica dentro da amostra de empresas classificadas no "Nível II" e aplicação da "Ferramenta de Auditoria do Produto".

Objetivos: mensurar o grau de atendimento das exigências do mercado, em relação às macro dimensões performance técnica e performance de interface, de produtos desenvolvidos por empresas de base tecnológica. A utilização de empresas classificadas no "Nível II", que apresenta como característica o desenvolvimento de produtos sem a integração do design ao processo ou utilização superficial, é essencial para uma análise comparativa que pretende avaliar quais são as conseqüências desta abordagem para a competitividade potencial dos produtos. A seleção de produtos de empresas de base tecnológica para os estudos de caso visa aumentar a capacidade de generalização da análise, buscando homogeneizar ao máximo as condições de contorno do objeto estudado.

Técnicas de coletas e análise de dados: Aplicação da "Ferramenta de Auditoria do Produto" para cada produto selecionado no "Nível II", de acordo com a metodologia própria da ferramenta, detalhada no item 1.2.4. As empresas classificadas no Nível II já possuem protótipos dos produtos que desenvolveram, normalmente colocados no mercado sem a intervenção do design industrial. Desta forma, é possível avaliar o potencial de sucesso do produto, uma vez estabelecidos os critérios performance técnica e performance de interface como desejáveis para a competição salutar no mercado atual. A "Ferramenta de Auditoria do Produto" abarca estas duas macro-dimensões a partir de várias subdimensões, o que permitirá, além de observar o potencial de sucesso do produto no mercado, avaliar o grau de utilização de design industrial da empresa no processo de desenvolvimento de produtos. 


\subsubsection{Etapa IV}

Condução de novo processo de desenvolvimento de produtos para empresas classificadas no "Nível II" e aplicação da "Ferramenta de Auditoria do Produto" nos novos produtos desenvolvidos

Objetivos: mensurar se os produtos submetidos a um novo processo de desenvolvimento, com ênfase nas "Boas Práticas" propostas, atendem melhor às dimensões performance técnica e performance de interface do que os anteriores e avaliar benefícios e barreiras para a integração precoce do design ao PDP.

Técnicas de coleta e análise de dados: acompanhamento do PDP, através da observação presencial em reuniões, atuação no processo, análise documental e entrevistas com os participantes; aplicação da "Ferramenta de Auditoria dos Produtos" aos novos produtos desenvolvidos. Serão observados:

- Recursos despendidos para o novo desenvolvimento (tempo, pessoal, equipamentos, material, protótipos etc);

- Intensidade das mudanças necessárias no projeto mecânico, mecatrônico, materiais, etc (performance técnica) para atender a especificações relacionadas à performance de interface (design industrial);

- Melhorias implementadas no produto, não apenas as mais evidentes, bem como as intangíveis

\subsubsection{Etapa $V$}

Desenvolvimento dos produtos classificados no "Nível III" e aplicação da "Ferramenta de Auditoria do Produto" nos produtos desenvolvidos 
Objetivos: mensurar se nos produtos onde a integração do design industrial ao PDP é feita precocemente - no início do PDP - através das "Boas Práticas", as dimensões performance técnica e performance de interface são atendidas prontamente; avaliar benefícios e barreiras para a integração precoce do design ao PDP.

Técnicas de coleta e análise de dados: acompanhamento do PDP, através da observação presencial em reuniões, atuação no processo, análise documental e entrevistas com os participantes; aplicação da "Ferramenta de Auditoria dos Produtos" aos novos produtos desenvolvidos. Serão observados:

- Recursos despendidos para o desenvolvimento (tempo, pessoal, equipamentos, material, protótipos, etc);

- Melhorias implementadas no produto, não apenas as mais evidentes, bem como as intangíveis

\subsubsection{Etapa $V I$}

Comparações entre os resultados.

Objetivos: primordialmente, avaliar se a integração precoce do design industrial no PDP é benéfica, quais seriam estes benefícios e quais são as possíveis barreiras existentes. Secundariamente, coletar evidências sobre como as empresas estão desenvolvendo seus produtos, se estão potencialmente preparados ao mercado atual e aspectos da dinâmica da integração entre designers e engenheiros no processo e sua problemática.

Técnicas de análise de dados: análise comparativa entre os resultados da "Ferramenta de Auditoria do Produto", articulação de possíveis correlações qualitativas entre diversos 
aspectos da integração design industrial e engenharia, sua relação com o setor empresarial brasileiro e sua problemática.

\subsection{4. "Ferramenta de Auditoria do Produto"}

A "Ferramenta de Auditoria do Produto" é uma adaptação da ferramenta "Design Audit Tool" apresentada no workbook Assessing and improving product design capability (MOULTRIE; FRASER, 2004, p.03-28), resultado do programa Good Design Pratice do Institute for Manufaturing (IfM) e Engineering Design Centre - ambos do Departamento de Engenharia da Universidade de Cambridge - e Industrial Design Engineering Group do Royal College of Art - ambas universidades do Reino Unido.

\subsubsection{Descrição da "Ferramenta de Auditoria do Produto"}

A auditoria do produto permite ao time de projeto avaliar a performance relativa da oferta de produtos atual em relação a um número de dimensões-chave: utilidade/benefícios centrais, qualidade de engenharia, usabilidade, desejabilidade, novidade/originalidade, produtibilidade, lucratividade e diferenciação de produtos atuais.

Esta análise oferece ao time de projeto indicadores sobre as forças e fraquezas do produto, permitindo priorizar iniciativas de melhoria.

A auditoria de produto é um precursor ideal para uma avaliação do processo de design e embasa tanto o planejamento de projeto quanto a melhoria do processo.

A ferramenta desenvolvida pode ser aplicada por pessoas da própria equipe, que normalmente terá uma gama de visões sobre a importância do "bom design" e até mesmo do

\footnotetext{
${ }^{1}$ Optou-se por traduzir "design" como "produto", considerando que o termo refere-se ao resultado do processo de design, no caso, um produto.
} 
que é o "bom design". Elas terão uma gama de visões sobre o quanto os produtos atuais são bem desenvolvidos e quão efetivamente os projetos são gerenciados. Um dos principais objetivos da ferramenta é conjugar visões diferentes e oferecer uma estrutura para discussão, debate e melhoria. Idealmente, deve existir uma perspectiva multifuncional em todos os estágios.

\subsubsection{A visão do usuário sobre qualidade do produto}

Embora "bom design" seja difícil de definir, algum tema comum se mantém através de setores industriais e tipos de produto. Da perspectiva do usuário/consumidor, produtos bem projetados tendem a combinar as seguintes qualidades:

- Benefício central / Utilidade - Funciona bem e tem desempenho de acordo com o prometido, satisfazendo um nível de performance mínimo ou apropriado.

- Qualidade de engenharia - O produto é bem projetado: robusto, confiável, durável e eficiente.

- Usabilidade - Tem ergonomia apropriada e interface com usuário eficaz que é simples de entender e operar.

- Desejabilidade - É bonito! Tipicamente, consumidores pagarão um preço "Premium" se o seu desejo for maior que a sua necessidade do produto. Desejabilidade é uma forte influência na decisão de compra, especialmente quando a performance e preços de produtos alternativos são semelhantes. A estética de um produto deve ser apropriada para o mercado pretendido, os usuários e o ambiente de utilização. Esta qualidade subjetiva do produto pode ser melhor avaliada quando confrontada com produtos concorrentes ou complementares. 
- Novidade/Originalidade - Em geral, há uma expectativa que novo corresponde a melhor. Abordagens originais podem ser aplicadas para todos os elementos do design $\operatorname{mix}^{2}$ e o consumidor vai procurar, na maioria das vezes, soluções que incorporam abordagens inovadoras ou criativas para solucionar problemas de formas mais eficientes e eficazes.

Estes elementos se aplicam tanto para bens de consumo quanto para produtos industriais, embora a importância relativa possa variar.

\subsubsection{A visão da empresa sobre qualidade do produto}

Da perspectiva do fabricante, "bom design" pode ser visto como uma ferramenta estratégica para melhorar a posição de mercado, oferecer sucesso comercial de longo-prazo e construir orgulho da empresa para a gama de produtos. Da perspectiva do fabricante, produtos bem projetados tendem a combinar as seguintes qualidades:

- Produtibilidade - O produto pode ser produzido economicamente em escala, utilizando métodos de produção apropriados, considerando o impacto de novos componentes, montagens e processos para a organização. Um efetivo Design for Manufacture (DfM) envolve otimização da arquitetura do produto, montagem e processos.

- Diferenciação - A empresa procura diferenciar sua oferta de produtos pelo oferecimento de originalidade em ou mais elementos do design mix. Diferenciação pode ser obtida através da satisfação de benefícios centrais para usuários de novas formas, pela entrega de excelência em um dos atributos físicos dos produtos ou pela oferta de serviços de apoio excepcionais.

\footnotetext{
${ }^{2}$ Design Mix: o conjunto dos atributos e características dos produtos, incluindo os atributos tangíveis, baseados nas engenharias e que são na maioria das vezes quantificáveis e mensuráveis - como dimensões, componentes, peso, eficiência energética, materiais, força, precisão, margem de erro etc - e os intangíveis, atributos focados nos usuários e que são na maioria das vezes qualitativos e subjetivos - como usabilidade, aparência, estilo, valores simbólicos, feel etc. (IFM; 2007).
} 
- Lucratividade - Produtos que são claramente diferenciados, que atendem a necessidades reais e podem ser produzidos eficientemente serão normalmente lucrativos. Um produto não pode ser considerado realmente bem projetado a menos que também consiga recompensas suficientes ao negócio, medida em termos de fatia de mercado, margem de lucro, faturamento ou volume de vendas. Recompensas financeiras instantâneas podem ser complementadas por outros benefícios aos negócios, como presença de mercado, desenvolvimento de mercado ou desenvolvimento da marca.

\subsubsection{Aplicação}

A "Ferramenta de Auditoria do Produto" tem por objetivo oferecer uma revisão rápida da performance do projeto de produtos existentes, observando dimensões-chave (ver Quadro 1.2).

\section{Quadro 1.2 - Dimensões-chave para avaliação da performance}

\begin{tabular}{|c|c|}
\hline \multirow{5}{*}{ 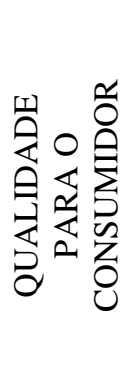 } & Benefício central / Utilidade \\
\hline & Qualidade de engenharia \\
\hline & Usabilidade \\
\hline & Desejabilidade \\
\hline & Novidade/Originalidade \\
\hline \multirow{3}{*}{ 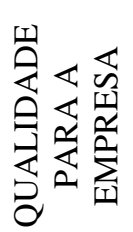 } & Produtibilidade \\
\hline & Diferenciação \\
\hline & Lucratividade \\
\hline
\end{tabular}

FONTE: adaptado de MOULTRIE e FRASER, 2004.

Cada dimensão da qualidade para o consumidor é avaliada e relacionada com a importância de cada dimensão para o consumidor. Desta forma pode-se avaliar como a performance do produto existente atende (potencialmente) às expectativas dos usuários e 
consumidores, o que, em última instância, é um bom indicador do seu futuro desempenho comercial. Também será um bom indicador sobre como o processo de desenvolvimento abarcou estas considerações, oferecendo a possibilidade de inferir possíveis disfunções e barreiras.

As dimensões de qualidade para a empresa também são avaliadas, embora não sejam confrontadas com nenhum indicador. A ferramenta original não oferece os parâmetros para comparação.

Para este trabalho, as dimensões produtibilidade e lucratividade não serão avaliadas, por que: (i) verificou-se, através da aplicação preliminar desta ferramenta, que as empresas de pequeno porte têm certa dificuldade de responder às questões relacionadas à adequada avaliação destas dimensões; (ii) alguns produtos não foram desenvolvidos completamente ou ainda não chegaram ao mercado, o que impossibilitaria a avaliação.

\subsubsection{Pontuação}

Na primeira etapa, para cada dimensão da "Qualidade para o Consumidor" (ver Quadro 1.3) deve ser atribuído um valor de 1 a 4 , sendo 1 pouco importante e 4 muito importante. Esta discussão deve ser alvo de muitos conflitos e é natural que seja assim. Os participantes tendem, de acordo com a sua formação, julgar certos aspectos como mais relevantes. Desta forma, é importante que diversas áreas sejam representadas, incluindo até mesmo representantes do público-alvo. Recomenda-se utilizar de produtos concorrentes, similares, estudos, artigos, anúncios publicitários e quaisquer outras ferramentas necessárias para se estabelecer paralelos. 


\begin{tabular}{|c|c|c|c|c|c|c|}
\hline \multicolumn{7}{|c|}{ I mportância para os Usuários/ Consumidores } \\
\hline $\begin{array}{l}\text { Benefícios } \\
\text { Centrais }\end{array}$ & Poucos benefícios reais gerais & 1 & 2 & 3 & 4 & Benefícios gerais relevantes \\
\hline $\begin{array}{l}\text { Qualidade de } \\
\text { Engenharia }\end{array}$ & $\begin{array}{l}\text { Qualidade de engenharia geral } \\
\text { não é importante }\end{array}$ & 1 & 2 & 3 & 4 & $\begin{array}{l}\text { Qualidade de engenharia geral } \\
\text { importante }\end{array}$ \\
\hline Usabilidade & Usabilidade não é importante & 1 & 2 & 3 & 4 & Usabilidade muito importante \\
\hline Desejabilidade & $\begin{array}{r}\text { Desejabilidade não é } \\
\text { importante }\end{array}$ & 1 & 2 & 3 & 4 & $\begin{array}{l}\text { Desejabilidade é muito } \\
\text { importante }\end{array}$ \\
\hline Novidade & Novidade não é importante & 1 & 2 & 3 & 4 & Novidade é muito importante \\
\hline $\begin{array}{l}\text { Diferenciadores } \\
\text { principais } \\
\text { requisitados... }\end{array}$ & & & & & & \\
\hline
\end{tabular}

FONTE: adaptado de MOULTRIE e FRASER, 2004.

$\mathrm{Na}$ segunda etapa, cada dimensão-chave, como "Qualidade de Engenharia”, é decomposta em um número de aspectos mais detalhadas, como "confiabilidade" ou “qualidade de construção" (ver exemplo em Quadro 1.4 - todas as tabelas podem ser encontradas no Anexo A).

Para cada aspecto deverá ser atribuído um valor, numa escala de 1 a 4 , onde tipicamente 1 representa baixa performance e 4 excelente performance.

A avaliação é feita em grupo, com o maior número possível de representantes de diversas áreas e expertise. Mais do que atribuir um valor de acordo com a sua própria opinião, cada aspecto deve ser discutido até se atingir certo consenso sobre o valor. Isto encoraja o debate e fornece pontos que podem ser anotados para discussão mais aprofundada.

Depois de pontuar cada aspecto da dimensão, deve-se discutir e pontuar a performance geral da dimensão, ao invés de fazer uma simples média da pontuação de cada aspecto. Esta pontuação deve ser discutida até a concordância de todos os participantes. 
Quadro 1.4 - Exemplo: quadro da dimensão "Qualidade de Engenharia" e seus aspectos decompostos

\begin{tabular}{|c|r|c|c|c|c|c|c|}
\hline Qualidade de Engenharia... \\
\hline Questão & Baixa Performance & \multicolumn{3}{|c|}{ Pontuação } & \multicolumn{1}{|c|}{ Excelente Performance } \\
\hline Performance & $\begin{array}{r}\text { Promessas demais e } \\
\text { performance de menos }\end{array}$ & 1 & 2 & 3 & 4 & $\begin{array}{l}\text { Performance excede } \\
\text { expectativas }\end{array}$ \\
\hline Confiabilidade & $\begin{array}{r}\text { Não-confiável - falha } \\
\text { regularmente em trabalhar } \\
\text { corretamente }\end{array}$ & 1 & 2 & 3 & 4 & $\begin{array}{l}\text { Um cavalo de trabalho - 100\% } \\
\text { confiável }\end{array}$ \\
\hline $\begin{array}{r}\text { Qualidade de } \\
\text { Construção }\end{array}$ & $\begin{array}{r}\text { Construção pobre - parece-se e } \\
\text { percebe-se como barato }\end{array}$ & 1 & 2 & 3 & 4 & $\begin{array}{l}\text { Construído solidamente e } \\
\text { com boa engenharia }\end{array}$ \\
\hline Durabilidade & $\begin{array}{r}\text { Durabilidade pobre - tendência a } \\
\text { quebrar ou parar de trabalhar }\end{array}$ & 1 & 2 & 3 & 4 & $\begin{array}{l}110 \% \text { durável - irá superar a } \\
\text { concorrência }\end{array}$ \\
\hline & $\begin{array}{r}\text { Qualidade de engenharia } \\
\text { pobre - geral }\end{array}$ & $\mathbf{1}$ & $\mathbf{2}$ & $\mathbf{3}$ & $\mathbf{4}$ & $\begin{array}{l}\text { Qualidade de engenharia } \\
\text { excelente - geral }\end{array}$ \\
\hline
\end{tabular}

FONTE: adaptado de MOULTRIE e FRASER, 2004.

A terceira etapa consiste na compilação de todas as dimensões em um quadro, bem como a importância atribuída pelos usuários/consumidores para cada dimensão (ver Quadro $1.5)$.

Este quadro permitirá a construção de um gráfico, onde as coordenadas de cada dimensão são constituídas pelo valor atribuído de importância para o consumidor e o valor atribuído ao produto atual. Desta forma, elementos que são de alta importância para os consumidores mas foram executados pobremente, potencialmente necessitam de melhorias. Também podem indicar aspectos do processo, como a observância apenas dos aspectos de performance técnica, relegando para um segundo plano os aspectos de performance de interface - o que do ponto de vista deste trabalho seria uma disfunção não desejável. 
Quadro 1.5 - Quadro de compilação final - dimensões vs. importância para usuário/consumidor

\begin{tabular}{|c|c|c|c|c|c|c|}
\hline \multicolumn{6}{|c|}{ Resumo da Auditoria do Produto } & \multirow[t]{2}{*}{ Produto } \\
\hline \multicolumn{6}{|c|}{ Performance do Produto } & \\
\hline Questão & Baixa Performance & \multicolumn{4}{|c|}{ Pontuação } & Excelente Performance \\
\hline Produtibilidade & Produtibilidade geral pobre & 1 & 2 & 3 & 4 & Produtibilidade geral boa \\
\hline Lucratividade & Lucratividade geral pobre & 1 & 2 & 3 & 4 & Lucratividade geral boa \\
\hline $\begin{array}{l}\text { Benefícios } \\
\text { Centrais }\end{array}$ & Poucos benefícios reais & 1 & 2 & 3 & 4 & Benefícios gerais relevantes \\
\hline $\begin{array}{l}\text { Qualidade de } \\
\text { Engenharia }\end{array}$ & $\begin{array}{r}\text { Qualidade de engenharia geral } \\
\text { pobre }\end{array}$ & 1 & 2 & 3 & 4 & $\begin{array}{l}\text { Qualidade de engenharia } \\
\text { geral excelente }\end{array}$ \\
\hline Usabilidade & Usabilidade geral pobre & 1 & 2 & 3 & 4 & Usabilidade geral boa \\
\hline Desejabilidade & Desejabilidade geral baixa & 1 & 2 & 3 & 4 & Desejabilidade geral alta \\
\hline Novidade & Pouca novidade geral & 1 & 2 & 3 & 4 & Boa novidade geral \\
\hline \multicolumn{7}{|l|}{$\begin{array}{l}\text { Diferenciadores } \\
\text { principais } \\
\text { oferecidos... }\end{array}$} \\
\hline \multicolumn{7}{|c|}{ I mportância para os Usuários/ Consumidores } \\
\hline $\begin{array}{l}\text { Benefícios } \\
\text { Centrais }\end{array}$ & Poucos benefícios reais gerais & 1 & 2 & 3 & 4 & Benefícios gerais relevantes \\
\hline $\begin{array}{l}\text { Qualidade de } \\
\text { Engenharia }\end{array}$ & $\begin{array}{l}\text { Qualidade de engenharia geral } \\
\text { não é importante }\end{array}$ & 1 & 2 & 3 & 4 & $\begin{array}{l}\text { Qualidade de engenharia } \\
\text { geral importante }\end{array}$ \\
\hline Usabilidade & Usabilidade não é importante & 1 & 2 & 3 & 4 & Usabilidade muito importante \\
\hline Desejabilidade & Desejabilidade não é importante & 1 & 2 & 3 & 4 & $\begin{array}{l}\text { Desejabilidade é muito } \\
\text { importante }\end{array}$ \\
\hline Novidade & Novidade não é importante & 1 & 2 & 3 & 4 & Novidade é muito importante \\
\hline $\begin{array}{l}\text { Diferenciadores } \\
\text { principais } \\
\text { requisitados... }\end{array}$ & & & & & & \\
\hline
\end{tabular}

FONTE: adaptado de MOULTRIE e FRASER, 2004.

Neste trabalho não será utilizado um gráfico com quadrantes como proposto originalmente para a apresentação dos resultados, mas um gráfico de barras. Ao invés disso, para a análise da situação de cada dimensão, será utilizado um fator, obtido a partir da razão entre o valor atribuído pela equipe na avaliação do produto (situação atual) e o valor que representa a importância dada à dimensão pelo usuário (situação desejável). Valores menores 
que 1 indicam necessidade de melhoria; valores maiores que 1 indicam performance acima da média. Esta forma de tratamento dos dados permitirá uma forma mais quantitiva de análise, tornando possível observar o desvio em relação do fator de performance ótima, bem como permitirá uma visualização de múltiplos casos em um mesmo gráfico, melhorando a apresentação dos dados.

A ferramenta original prevê outra fase, onde é construída tabela de forças e fraquezas nas diversas dimensões, detalhando-as num nível onde é possível desenvolver plano de ação de curto, médio e longo prazo. Devido ao propósito deste trabalho, esta etapa não será realizada.

A ferramenta também prevê a pontuação de um produto concorrente, para efeito de comparação. Para este trabalho, os produtos concorrentes foram considerados numa pesquisa prévia por todos os participantes, mas por motivos legais não serão apresentados.

Participaram da pontuação designers industriais, engenheiros mecânicos, mecatrônicos, materiais, profissionais de marketing, publicitários e representantes dos usuários, de acordo com a disponibilidade e tipo de produto - tanto da equipe interna de projeto quanto da empresa.

\subsubsection{Análise}

Para este trabalho, as dimensões elencadas pela ferramenta original são relacionadas com as macro-dimensões performance técnica e performance de interface, de acordo com o Quadro 1.6. Esta relação foi construída a partir da atribuição das responsabilidade das áreas de engenharia de produto e design industrial, de acordo com seu corpo teórico, seus métodos e objetivos de projeto. Obviamente, a dimensões são interrelacionadas e decisões de uma área influenciam na outra, tornando complexo realizar esta divisão. Cabe ressaltar que a percepção 
de qualidade do ponto de vista do consumidor não acontece de forma analítica, decompondo as partes e analisando conscientemente cada uma em separado, mas num processo global e holístico, onde o todo é mais do que a soma das partes. Desta forma, a divisão aqui utilizada se presta a um método analítico necessário a este trabalho.

Quadro 1.6 - Correlação entre as dimensões da ferramenta e as macro-dimensões de
performance técnica e de interface
\begin{tabular}{|l|c|c|}
\hline \multicolumn{1}{|c|}{ Dimensão } & Tipo de Performance \\
\hline Benefício central / Utilidade & técnica & interface \\
\hline Qualidade de engenharia & TÉCNICA & interface \\
\hline Usabilidade & técnica & INTERFACE \\
\hline $\begin{array}{l}\text { Desejabilidade } \\
\text { * As dimensócnica }\end{array}$ & INTERFACE \\
\hline $\begin{array}{l}\text { Novidade/Originalidade } \\
\text { técnica }\end{array}$ & interface \\
\hline
\end{tabular}
influência predominante da dimensão na performance.

O produto existente fornecerá algumas indicações da eficácia do PDP, ou seja, seu resultado. Um PDP eficaz, de acordo com os pressupostos deste trabalho, é aquele que entrega um produto que atenda tanto às necessidades de performance técnica quanto de performance de interface, estabelecidas como essenciais para competir no mercado atual. $\mathrm{O}$ mapeamento da performance atual do produto vs. importância para o consumidor permitirá observar pontos de melhoria e inferir se os produtos atuais desenvolvidos pela empresas de base tecnológica possuem as características necessárias para obterem, potencialmente, sucesso no mercado atual. Permitirá, após novo desenvolvimento, comparar a nova performance com a performance original, após a integração do design industrial no início no processo, oferecendo um indicador dos benefícios.

O produto existente também fornecerá algumas indicações sobre o próprio processo de desenvolvimento de produtos. Desta forma, é possível, a partir da avaliação do produto, 
realizar inferências sobre características deste processo, como o estágio e a forma de integração do design, valorização dos aspectos de performance técnica em detrimento da performance de interface, ou vice-versa, entre outras características.

\subsubsection{Materiais $\boldsymbol{e}$ instalações}

Foram utilizadas as instalações da Fundação Parque de Alta Tecnologia São Carlos (Parqtec), mais especificamente dos seus Núcleos de Design Industrial (Instituto Parqtec de Design - IPD) e de Engenharia e Prototipagem Rápida (NEPR). Estes núcleos possuem boa estrutura para o desenvolvimento de projetos integrados de produtos, considerando que se destinam a esta atividade.

Uma importante vantagem da utilização desta estrutura, mais do que os equipamentos, é a existência de uma equipe ampla, composta por designers industriais e engenheiros com boa formação acadêmica e prática, experiência no desenvolvimento de produtos para micro e pequenas empresas e uma visão integradora das diferentes áreas no PDP. Estes núcleos já atuam desde 1999 no diagnóstico, análise e inserção do processo de desenvolvimento de produtos em incubadoras, Arranjos Produtivos Locais e outros tipos de grupos de empresas em diversas cidades do interior de São Paulo, tendo desenvolvido e aplicado metodologia que abarca desde a conscientização do empresariado à prestação de serviços de desenvolvimento de produtos em si.

A parceria e os convênios com diversas agências de fomento (Sebrae - Serviço Brasileiro de Apoio às Micro e Pequenas Empresas, Finep - Financiadora de Estudos e Projetos, CNPq - Conselho Nacional de Desenvolvimento Científico e Tecnológico, ISCB Intenacional Council for Small Business e outros), com universidades e centros de pesquisa (USP - Univesidade de São Paulo, Unesp - Univesidade Estadual Paulista "Júlio de 
Mesquista Filho", UFSCar - Universidade Federal de São Carlos, Belas Artes - Centro Univesitário Belas Artes São Paulo, NUMA - Núcleo de Manufatura Avançada / Instituto Fábrica do Milênio, entre outros) e o fato dos núcleos integrarem a estrutura do Parqtec - que implantou a primeira incubadora de empresas de alta tecnologia da América Latina, em 1984, e hoje desenvolve diversas atividades no Estado de São Paulo - permitem o contato constante e profundo dos núcleos com empresas de diversos setores e portes espalhadas pelo Estado de São Paulo, especialmente nascentes, e com políticas de fomento que visam compreender e potencializar o empreendedorismo no Brasil, constituindo então um ambiente altamente privilegiado para os objetivos de investigação deste estudo.

\subsection{ESTRUTURA DO TRABALHO}

Este trabalho está estruturado em 5 capítulos. O capítulo 1 apresenta o tema, sua problemática e relevância, os objetivos e o método utilizado. No capítulo 2 é apresentada a revisão da literatura e fundamentação teórica. A primeira parte tem por objetivo estabelecer um panorama de fundo sobre a integração do design industrial à engenharia, levantar evidências sobre a real eficácia deste tipo de prática e definir a terminologia utilizada ao longo deste trabalho. A segunda parte é realizada de forma crítica, articulando diversas fontes numa tentativa de delinear os aspectos de contorno do fenômeno da integração do design industrial à engenharia no processo de desenvolvimento de produtos e explicitar as bases sobre as quais se fundamentam este trabalho. No capítulo 3 são apresentadas propostas do autor para a abordagem teórica e prática do assunto: um framework, baseado na literatura e na prática, para orientar o estudo deste tipo de fenômeno, uma vez que foi observada uma carência na literatura deste tipo de ferramenta conceitual específica; um conjunto de "Boas Práticas", dividido em primária e secundárias, inferidos de práticas de empresas de sucesso reconhecidas por sua utilização intensa de design industrial e de grupos de pesquisa 
relacionados ao tema. As "Boas Práticas" foram aplicadas a estudos de caso, tanto com o objetivo de oferecer um diálogo teórico-empírico quanto para melhorar a própria prática. No capítulo 4 são apresentados os resultados através dos estudos de caso, seguindo-se uma análise orientada pelas perguntas da pesquisa e uma análise orientada pelo framework proposto. No capítulo 5 são feitas as considerações finais e uma breve discussão das implicações teóricas e práticas deste estudo. 


\section{REVISÃO BIBLIOGRÁFICA E FUNDAMENTAÇÃO TEÓRICA}

\subsection{FUNDAMENTOS DO DESIGN E DA ENGENHARIA PARA A COMPETITIVIDADE}

A competição entre as empresas foi modificada drasticamente no final do século XX. A computação ubíqua a evolução e disseminação da tecnologia da informação, os métodos de produção enxuta, a terceirização da produção e a personalização dos produtos são alguns dos fatores que influenciaram o deslocamento do paradigma da Produção em Massa para a Customização Maciça ${ }^{3}$.

FASCIONI (2003, p.1) comenta que "a popularização das tecnologias microeletrônicas e dos processos de qualidade tem tornado os bens de consumo cada vez mais semelhantes e com capacidades e funcionalidades análogas." Sobre esta questão, PETERS (2002* apud FASCIONI, 2003, p.1) conclui que o sucesso de métodos como o Seis Sigma, entre outros, transformou a qualidade em commodity, não sendo mais determinante como diferencial no processo de compra. Ainda, afirma que o design é "a diferença" num mundo carregado de objetos parecidos.

\footnotetext{
3 "Enquanto os praticantes da Produção em Série [Massa] partilham metas comuns de desenvolvimento, produção, comercialização e entrega de mercadorias e serviços a preços baixos o suficiente para que quase todos tenham acesso a eles, os praticantes da Customização Maciça partilham metas de desenvolvimento, produção, comercialização e entrega de produtos e serviços disponíveis com suficiente variedade e personalização para que quase todos encontrem exatamente o que eles querem. A lógica da Produção em Série, que Henry Ford descobriu e colocou em prática, foi a de que preços mais baixos resultam em grandes vendas; grandes vendas resultam em maiores volumes; maiores volumes resultam em custos mais baixos; e custos mais baixos, retomando ao início do ciclo, permitem preços ainda mais baixos; e assim por diante. Os pioneiros da Customização Maciça descobriram uma nova lógica, mais adequada a um mundo no qual estabilidade e controle não podem ser mantidos por muito tempo. Aqui, uma companhia que melhor satisfaça as vontades e necessidades de seus consumidores individuais terá maiores vendas. Com maiores lucros, bem como com um melhor entendimento das exigências dos consumidores, a companhia pode proporcionar maior variedade e personalização, o que posteriormente fragmentará ainda mais o mercado. Por estar distanciando os concorrentes quanto à variedade e à personalização, a fragmentação do mercado permite, mais uma vez, a maior satisfação das vontades e necessidades dos consumidores, e assim por diante." (PINE II, 1994)

* PETERS, T. Management guru Tom Peters on design. Issue Journal, Corporate Design Foundation. Disponível em <http//www.cdf.org/tompeters/tompeters.html>. Acesso em: 30 abr. 2002.
} 


\subsubsection{A importância internacional do design}

Nos países desenvolvidos, a importância do design para a competitividade das empresas é vista a partir da perspectiva de integração entre design industrial e engenharia de produto, como resposta ao paradigma atual de competição. Este fenômeno parece ser mais claro às empresas e estudado com maior profundidade e interdisciplinaridade na academia dos países desenvolvidos do que no Brasil.

No âmbito acadêmico internacional, a discussão é bastante ativa, permeando publicações relacionadas não apenas à área de design industrial, mas também às áreas de engenharia mecânica, engenharia de produção, administração, negócios e inovação. Boa parte das publicações são feitas por pesquisadores dos departamentos de engenharia, que tomaram para si a responsabilidade de discutir o assunto da integração com o design industrial.

No Brasil, por sua vez, a discussão em torno do assunto parece carecer de amplitude, profundidade e interdisciplinaridade. Artigos publicados sobre o assunto por departamentos de engenharia são muito escassos. Boa parte dos estudos encontrados é realizado e publicado por designers, e não engenheiros ${ }^{4}$, nos departamentos de engenharia de produção e discorrem, na maioria das vezes, sobre gestão do design. Pouquíssimos artigos foram encontrados especificamente sobre integração entre design e engenharia, tocando em pontos críticos deste assunto. Desta forma, serão utilizados como base essencialmente referências internacionais.

\footnotetext{
${ }^{4}$ Este comentário foi feito pois parece relevante que, nos países desenvolvidos, boa parte dos estudos e publicações são realizadas por iniciativa de departamentos de engenharia e realizados por engenheiros, demonstrando que o assunto não está restrito aos departamentos de design industrial. Isto fornece evidências da relevância do tema e da sua capilaridade para outras áreas. Da mesma forma, muitos estudos são realizados em escolas de administração e negócios. No Brasil, o assunto parece muito concentrado nas mãos dos designers e nos departamentos de design, embora boa parte dos mestrados e doutorados encontrados tenham sido feitos em departamentos de engenharia de produção, fenômeno que talvez possa ser atribuído mais pela ausência, até recentemente, de cursos de pós-graduação nos departamentos de design, do que pela iniciativa dos departamentos de engenharia em estudar o tema.
} 
Um exemplo da capilaridade e da importância dada à integração do design industrial à engenharia nos países desenvolvidos, já há algum tempo, pode ser percebido em VOSS (1994), que entrevistou os membros do comitê editorial do Journal of Product Innovation Management sobre as mudanças e oportunidades que influenciariam a área de gerenciamento da inovação dos produtos na próxima década. Foi identificado o crescente reconhecimento da interdependência de uma variedade de processos de negócio: inovação de produto, desenvolvimento de produto, inovação de processo, aquisição de tecnologia, design industrial, gerenciamento da qualidade total e desdobramento da função qualidade (QFD); indicando a necessidade de estabelecer ligações mais estreitas entre estes importantes elementos para um programa de novos produtos de sucesso.

Os cursos de graduação e pós-graduação que possuem iniciativas integradoras em relação à engenharia mecânica, principalmente, e o design industrial (ex.: MechE Mechanical Engineering Department / Massachusetts Institute of Technology; Imperial College-London; Institute for Manufacturing (IfM), Mechanical Engineering Department / Cambridge; Industrial Design Engineering Department, Delft, Holanda, entre outros) e seus respectivos centros de pesquisa dedicados a esta aproximação; as ações governamentais para inserção do design industrial às empresas, especialmente as de menor porte (Design Council UK; Danish Design Center; Finnish Design Center, entre outros); os centros de desenvolvimento multidisciplinares das grandes empresas (Apple; Philips; Nokia; Sony; IDEO); os cada vez mais frequentes artigos de revistas técnicas e comerciais, livros e pesquisas que falam sobre "design estratégico", "user-centred design", "design-led innovation", "empresa focada no design", por exemplo, fornecem evidências da importância atribuída ao assunto nos países desenvolvidos e a proficuidade das suas discussões e aplicações práticas, indicando um movimento cada vez mais forte em direção à total integração entre as áreas - um movimento que já vem acontecendo há algum tempo. 
Nas grandes empresas, a consideração do design industrial estratégico é levada tão seriamente que, segundo BONSIEPE (1997, p. 22), “as grandes empresas começam a criar o cargo de vice-presidente de design". Sobre o mesmo assunto, LOBACH (2001) detalha casos das empresas Rosenthal, Olympia, Opel e Krupp, que muito cedo perceberam a importância estratégica do design industrial e criaram departamentos independentes de design subordinados diretamente à direção geral da empresa.

O design industrial, desta forma, é tratado como assunto estratégico, sendo colocado no centro do processo de decisões de grandes empresas, oferecido às pequenas empresas através de programas governamentais massivos, integrado à grade curricular e linhas de pesquisa dos cursos superiores em diversas áreas.

\subsubsection{Estudos sobre a eficácia do design para a competitividade}

Diversos estudos comprovam a importância de possuir um processo maduro de desenvolvimento de produtos, que permita a adequada integração do design industrial às engenharias, para aumentar a chance de sucesso comercial e financeiro das empresas.

O Design Council britânico conduziu o estudo The Impact of Design on Stock Market Performance: an analysis of UK quoted companies (DESIGN COUNCIL, 2004), com o objetivo de avaliar o impacto da utilização do design (visto de forma integrada: design industrial e engenharia de produto) na performance financeira das empresas. Para isso, acompanhou durante 10 anos o desempenho no mercado de ações de dois grupos de empresas, diferenciados pela intensidade de utilização do design. A principal conclusão da pesquisa é que as empresas que investiram continuamente em design - orientadas pelo design ${ }^{5}$ - obtiveram desempenho $200 \%$ maior do que a média geral de desempenho do FTSE 100 e

\footnotetext{
${ }^{5}$ No original: design-led companies
} 
FTSE All-Share ${ }^{7}$ (ver Figura 2.1). O apêndice do mesmo estudo apresenta outros 5 estudos similares que corroboram esta conclusão.

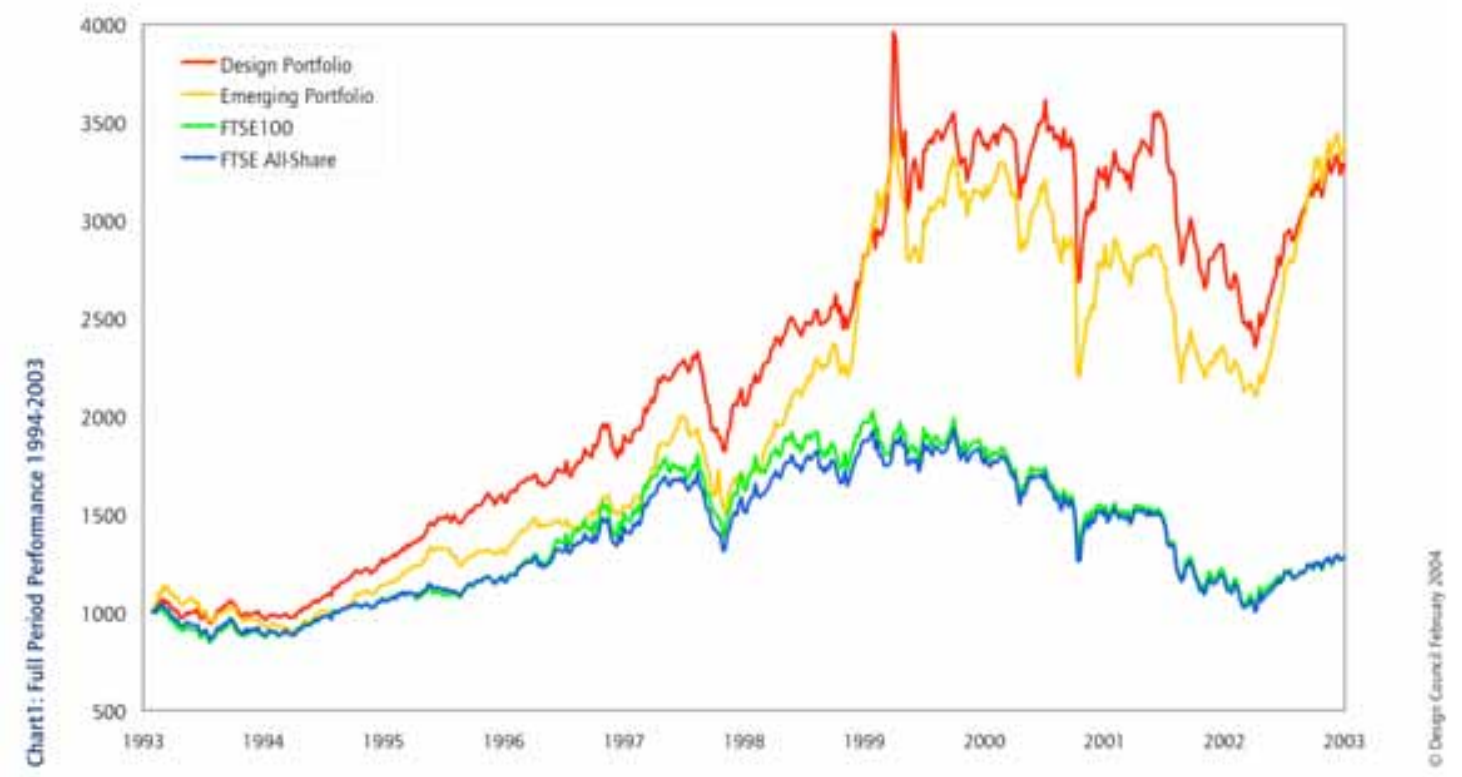

Figura 2.1 - Desempenho comparativo do portfolio de empresas que investem em design em relação às empresas em geral

FONTE: DESIGN COUNCIL, 2004. As linhas vermelha e amarela representam o desempenho do valor das ações das empresas que investem continuamente em design em relação à média geral das outras empresas.

Outro importante estudo em profundidade e com grande repercussão na Europa é o The Economics Effects of Design (NAEH \& DDC, 2003) realizado por duas agências dinamarquesas. O estudo desenvolveu um modelo de maturidade, referente à intensidade que a empresa insere o design em suas atividades, denominado "Escada do Design" ${ }^{8}$, com quatro níveis ou, analogamente, quatro degraus. Este modelo, proposto no estudo, se tornou uma espécie de padrão e diversos estudos similares foram conduzidos em diferentes países. A

\footnotetext{
${ }^{6}$ Tanto no "Bull" quanto no "Bear Market". Bull Market é uma situação de mercado caracterizada pela subida generalizada dos preços dos títulos cotados (acompanhada de certo otimismo generalizado). Bear Market é a situação inversa, caracterizada pela queda generalizada dos preços dos títulos (acompanhada de certo pessimismo generalizado).

${ }^{7}$ Financial Times Stock Exchange Authority (FTSE). É de propriedade da London Stock Exchange e Financial Times. O "FTSE 100 Share Index" é um indexador do mercado de ações composto pelas 100 maiores empresas britânicas em termos de capitalização de mercado.

${ }^{8}$ No original: Design Ladder
} 
principal conclusão é que as empresas que adotam uma abordagem de design ampla - isto é, quanto mais alto a empresa estiver na "Escada do Design" - faturam mais e geram mais exportações do que empresas que não utilizam design. Complementando,

\begin{abstract}
"as análises indicam uma ligação muito clara entre utilização de design e o sucesso econômico que as empresas atingem que por sua vez beneficia a sociedade como um todo. A correlação é tão evidente que não pode ser desconsiderada ou questionada. A correlação é especialmente evidente para empresas que adotam uma abordagem de design ampla. [...] Estas empresas experimentam um aumento no crescimento que é estatisticamente significante. Seu aumento na receita de exportação e performance de faturamento corresponde ao grau de adoção de uma abordagem ampla de design [...]." (NAEH \& DDC, 2003, p. 34).
\end{abstract}

HERTENSTEIN et al. (2005) realizaram estudo sobre o impacto do design industrial na performance financeira corporativa, utilizando 93 empresas divididas em dois grupos, classificadas de acordo com a intensidade de uso de design industrial. O desempenho financeiro, acompanhado através de indicadores tradicionais e no mercado de ações, foi acompanhado no período de 1995 a 2001. A conclusão é que existem fortes evidências relacionando boa performance financeira e no mercado de ações ao "bom design industrial"; além disso, os padrões de performance financeira ao longo do período de sete anos sugerem que estes efeitos são duradouros.

GEMSER e LEENDERS (2001) estudaram como e quando integrar o design industrial ao processo de desenvolvimento de produtos pode melhorar a performance da empresa, utilizando dados de 47 empresas holandesas. A conclusão é que a intensidade com que a empresa integra o design industrial no processo de desenvolvimento de novos produtos tem impacto positivo e significante na performance da empresa, especialmente quando a estratégia de investir em design é relativamente nova para o setor industrial.

O estudo Design as a force for development, realizado em 2002 pela Swedish Industrial Design Foundation para o Ministério da Indústria, Emprego e Comunicação da 
Suécia, gerou um programa para investimento governamental em design. O resultado deste programa foi avaliado por pesquisadores da School of Management and Economics da Universidade de Vaxto, Suécia. O relatório da avaliação foi publicado em $2006^{9}$ (JOHANSSON, 2006), concluindo que apoiar o programa foi um investimento de sucesso do governo. Como resultado direto, as empresas que participaram do programa experimentaram aumento nas vendas. O sucesso financeiro de $10 \%$ das empresas no programa empatou o total do investimento feito pelo governo. Como efeito secundário, mas não menos importante, dois terços das empresas no programa pretendem aumentar o investimento futuro em design.

A pesquisa The design difference (CENTRE FOR DESIGN INNOVATION, 2007), realizada pelo Institute of Technology da Irlanda, tem como conclusões centrais: empresas irlandesas que utilizam design têm mais sucesso que aquelas que não utilizam; design, inovação e crescimento estão interligados - pequenas e médias empresas que utilizam design são mais inovadoras que aquelas que não utilizam, saindo da competição apenas pelo preço e sendo mais competitivas globalmente; as empresas que estão crescendo mais rapidamente são aquelas que estão investindo em design.

O governo austríaco encomendou pesquisa The Austrian Design Ladder (GMBH, 2006) para determinar a consciência e a importância dada ao design pelas suas empresas, comparando-as com estudo similar conduzido com empresas na Suécia (SWEDISH INDUSTRIAL DESIGN FOUNDATION; SWEDISH ENGINEERING INDUSTRIES, 2004). Foram pesquisadas mais de 1000 empresas, em março de 2006, a grande maioria das pequenas e médias empresas, considerando que $98 \%$ das empresas deste país são deste porte. Os resultados apontam, demonstrados em comparação com pesquisa similar conduzida na Suécia, que: $50 \%$ das empresas austríacas utilizam o design sem consciência alguma (não-

\footnotetext{
${ }^{9}$ Com autoria de Ulla Johnson, Ph.D., professor da School of Management and Economics, Vaxto University, Suécia.
} 
design; design silencioso) ou como maquiagem de produto, o que indica que se deve realizar um esforço para as empresas subirem os "degraus da escada"; as empresas lucram com o design, considerando que $72 \%$ das empresas afirmaram que "design aumenta a lucratividade", comprovando, assim como na Suécia, que empresas que aplicam o design como estratégia são mais competitivas, mais abertas, mais inovadoras e demonstram melhor desempenho nas exportações.

O estudo Management of creativity and design within the firm (WHYTE; BESSANT; NEELY, 2005), realizado pelo Imperial College London e Advanced Institute for Management, ambos da Inglaterra, buscou investigar como a criatividade e o design podem ser utilizados para catalisar a inovação e serem utilizados como recursos estratégicos dos negócios. No caso, design foi visto como um processo de conjugar a compreensão de três dimensões: necessidades dos usuários (latentes ou expressas), forma (styling) e função obviamente além da visão simplista relacionada apenas à estética ou imagem. Segundo este estudo, há vastas evidências para apoiar a visão que o uso adequado de criatividade e design para permitir a inovação tem grande impacto na performance da empresa. Estas evidências estão compiladas em tabela, constituindo-se de 14 estudos conduzidos em diferentes continentes, e, embora variem a metodologia e a profundidade, a conclusão cabal é que design e inovação fazem a diferença.

KRISTENSEN et. al (2007) realizaram uma análise crítica dos principais estudos e artigos publicados que apontam para uma correlação entre utilização de design industrial e desempenho financeiro, realizando apontamentos críticos sobre as metodologias utilizadas e as conclusões. Após isso, realizaram sua própria pesquisa, utilizando dados financeiros de diversas naturezas de 27 das 100 maiores empresas dinamarquesas, no período 2000-2005, de 
diversos setores. A conclusão é que existe correlação positiva entre o "Bom Design" e desempenho financeiro.

Os estudos apresentados demonstram de forma contundente a correlação positiva entre a utilização de design e a performance comercial e financeira empresarial. Indicam também que, quando maior o grau de integração do design às atividades da empresa, maior o potencial de desempenho - evidenciados pela "Escada do Design". Faz-se necessário, então, aprofundar-se nas bases em que esta correlação se sustenta.

\subsubsection{Performance técnica e performance de interface}

Fruto da competição acirrada, o consumidor tem acesso a uma ampla variedade de produtos com funções equivalentes, qualidade comparável e preços similares, possuindo uma liberdade de escolha sem precedentes. Este fenômeno influenciou a noção de qualidade dos produtos, uma vez que entre produtos similares em diversos aspectos, a escolha se desloca razoavelmente para os atributos intangíveis dos produtos. A qualidade passa a ser, além da qualidade intrínseca do produto, influenciada por aspectos fisiológicos, psico-perceptivos, cognitivos, simbólicos, sociais - que pode ser denominada como qualidade "percebida".

\footnotetext{
“O objetivo da inovação tecnológica é vender lucrativamente o produto de um empreendimento industrial. Este objetivo pode ser alcançado somente se houverem consumidores desejosos. Se as características de um produto, além daquelas estritamente técnicas, são significantes em induzir a desejabilidade para adquiri-lo, omiti-las das especificações, dá-las pouca prioridade no desenvolvimento, lidá-las como um pensamento posterior ou executar estes aspectos do projeto sem expertise, irá reduzir as vendas potenciais do produto.”(MOODY, 1980, p.331).
} 
Um influente relatório publicado em 1979 (CORFIELD, 1979* apud. WHYTE; BESSANT; NEELY, 2005, p. 4) pelo National Economic Development Office da GrãBretanha, conclui que

\begin{abstract}
"a diferença entre as empresas e países aparentemente mais bem sucedidos e aqueles menos não está na quantidade de trabalho realizado, mas na qualidade; não no volume de produção final, mas no valor agregado a matéria-prima básica. Este valor é determinado mais pela qualidade do design e a forma como este atende às necessidades dos consumidores do que por outros fatores".
\end{abstract}

Como CLARK e FUJIMOTO e outros colocam (1990* apud. WHYTE; BESSANT; NEELY, 2005, p. 5), a revolução do paradigma de produção não foi confinada apenas ao lado produtivo da manufatura. O processo de design foi também alvo de grandes mudanças, com considerável esforço aplicado no campo de envolvimento altamente integrado. O resultado não foram apenas produtos projetados para qualidade, confiabilidade e manufatura limpa, mas também produtos cujos projetos capturassem a atenção e os "talões de cheque" dos consumidores.

Vários estudos confirmam empiricamente a importância de conciliar o desempenho técnico com o atendimento das necessidades físicas e psicológicas dos usuários (PETERS; WATERMAN, 1982; HOLT; GESCHKA e PETERLONGO, 1984; JUHLER, 1986; MCBURNIE e CLUTTERBUCK, 1987; DESIGN COUNCIL, 2004) demonstrando através de critérios de retorno de capital, desempenho comercial, na bolsa de valores, entre outros, que as empresas de maior sucesso são aquelas que adequadamente investigaram estas necessidades e desenvolveram uma interface nos seus produtos que às atendam adequadamente.

\footnotetext{
${ }^{*}$ CORFIELD, K. (1979) Product design. London, National Economic Development Office.

CLARK, K. and FUJIMOTO, T. (1990) 'The power of product integrity', Harvard Business Review (November-December): 107-118.
} 


\begin{abstract}
"Alguma luz é jogada na situação dos Estados Unidos por Peters e Waterman. Eles estudaram 62 empresas, representando um corte transversal na indústria americana. Por meio de critérios refletindo crescimento, criação de riqueza de longo prazo, retorno de capital, retorno de vendas e capacidade de inovação, eles selecionaram 21 empresas, posteriormente nomeadas 'as empresas de excelência', para estudos em profundidade. Uma de suas conclusões principais é que, em mais lugares do que o desejado ${ }^{10}$, os usuários são considerados uma inconveniência, a despeito de todo o discurso dado a orientação para o mercado. As 'empresas de excelência' são exceções: elas consideram de vital importância manter contato próximo com o usuário para obter informações adequadas sobre suas necessidades e preferências. Na Europa a situação parece ser a mesma". (HOLT, 1989, p.1645 , grifo nosso).
\end{abstract}

BAXTER (1998, p.21) coloca como conceito-chave que os novos produtos devem ser desenvolvidos orientando-se ao consumidor, tendo mais chances de sucesso se conseguirem interpretar as necessidades, sonhos, desejos, valores e expectativas do consumidor. Afirma que orientar os produtos ao atendimento das necessidades dos usuários resulta em cinco vezes mais chances de sucesso no mercado.

YAMAMOTO e LAMBERT (1994) realizaram um estudo sobre o impacto da estética do produto na avaliação de produtos industriais. Por avaliação deve-se entender a avaliação que as pessoas fazem de um produto e que gera um valor intangível, influenciando sua percepção de qualidade total do produto. A conclusão foi que, apesar do fato da aparência dos produtos normalmente não ser vista como algo que influencia na performance (técnica), foram encontradas evidências que a aparência de um produto industrial pode ter impacto sobre sua avaliação, em algumas circunstâncias excedendo a própria performance ou atributos de preço. Sugerem que dar a devida atenção à aparência do produto pode resultar em maior desempenho comercial.

MOODY (1980, p.338) argumenta que, a despeito do senso comum que o design tem impacto apenas nos produtos de consumo geral,

\footnotetext{
${ }^{10}$ No original: in too many places.
} 
"[...] é evidente que a apresentação do produto desempenha um importante papel na inovação tecnológica. Este papel é estabelecido principalmente por clientes demandando elegância em produtos e por pressão da competição exterior; outras razões relacionam-se com categorias de produtos particulares, mas são todas orientadas aos usuários/compradores. Não há dúvida que a aparência e a configuração dos produtos inflenciam o julgamento dos usuários e compradors. Desta forma, a apresentação do produto tem influência direta no sucesso comercial da inovação tecnológica. Enquanto é conhecimento comum que a apresentação afeta diretamente o sucesso comercial de produtos domésticos, as evidências sugerem que isto também é verdadeiro para produtos de base científica utilizados para propósitos industriais e profissionais.”

A aparência de um produto faz parte dos aspectos relacionados (deve-se registrar desde já que não é o único) à interface deste com seres humanos, principalmente aqueles ligados à percepção estética. Um produto não é avaliado pelos usuários/consumidores apenas pela função técnica que supre, nem somente pelo seu desempenho técnico com que o faz. Desta forma, parece pertinente adotar uma definição de produto mais ampla, englobando características mais intangíveis e, posteriormente, adotar um processo de desenvolvimento de produtos que contemple estas dimensões. O conceito das necessidades que o produto deve atender é ampliado. O "produto ampliado"11 apresenta as seguintes características (Fig. 2.2):

(i) A camada interna representa os benefícios básicos que são oferecidos aos consumidores e usuários;

(ii) A camada intermediária significa os atributos do produto que podem ser divididos em atributos tangíveis, que podem ser mensuráveis e quantificáveis (as características de performance física), e atributos intangíveis, aquelas qualidades subjetivas que são normalmente vistas como baseadas em opinião - como aparência, estilo, sentimentos, caráter e facilidade de uso;

\footnotetext{
11 O conceito de "produto ampliado", "extendido" ou com outras denominações similares é amplamente discutido na literatura relacionada ao Marketing. Neste estudo, pareceu desnecessário uma ampla discussão com embasamento neste tipo de literatura, pelo risco de desviar-se muito dos seus objetivos. Pareceu adequado adotar uma visão similar, mas com origem num grupo de pesquisa em engenharia, mais pertinente aos objetivos deste estudo e com o efeito de demonstrar que este tipo de abordagem, mais próxima das ciências sociais aplicadas, também é utilizada nesta área nos países desenvolvidos.
} 
(iii) A camada final representa os atributos de negócio e mercado que são essenciais para promover, vender e sustentar o produto.

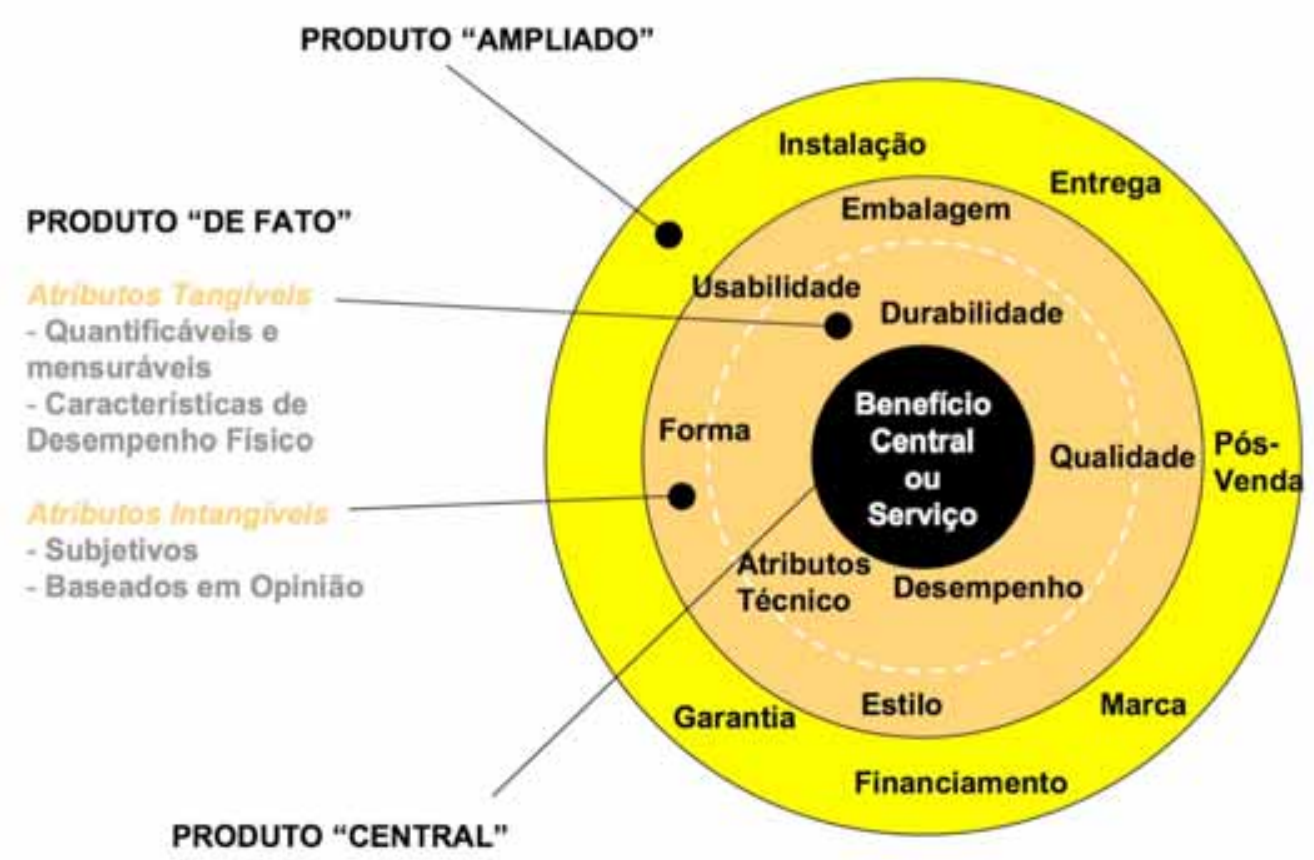

Figura 2.2 - O "produto ampliado"

FONTE: adaptado de IFM (Institute for Manufacturing), 2007

As características projetadas para que o desempenho do produto atenda às necessidades que tendem aos atributos mais intangíveis (mas não exclusivamente) serão denominadas neste trabalho PERFORMANCE DE INTERFACE com os seres humanos. Esta terminologia é equivalente ao termo conhecido como user-centred design e, por este motivo, também poderá ser utilizado ao longo deste trabalho.

As características projetadas para que o desempenho do produto atenda às necessidades que tendem aos atributos mais tangíveis serão denominadas neste trabalho PERFORMANCE TÉCNICA. 


\subsubsection{O conceito de "Bom Design"}

Existem diversas tentativas, ao longo da história, para definir o que é "Bom Design", no sentido de um conceito ou conjunto de critérios sobre "como o produto deveria ser". Este termo já foi utilizado para estabelecer parâmetros do que seria desejável nos produtos produzidos industrialmente, como o movimento Good Design americano e o movimento Gute Form $^{12}$ alemão, ambos referenciados nas experiências da Bauhaus (1919-1939). Estes conceitos foram se transformando ao longo do tempo.

O Institute for Manufacturing ${ }^{13}$ (IFM, 2007) analisa que, embora seja quase impossível definir o que é "Bom Design", temas comuns se manifestam através de setores industriais e tipos de produto - se referindo ao que seria um "Bom Design" tanto para a empresa, quanto para o consumidor. Um "Bom Design" de produto tende a combinar as seguintes qualidades:

(a) Útil - funciona bem e executa as funções conforme prometido; faz o que é esperado e satisfaz um nível mínimo e apropriado de performance;

(b) Utilizável ${ }^{14}$ - possui ergonomia e interface com o usuário apropriados, considerando como, onde, com que frequência e quem estará utilizando;

(c) Desejável ${ }^{15}$ - é bonito! O que é bonito depende da natureza do mercado, do estilo de vida, da cultura, da idade, do sexo, da educação, da ocupação e do cenário de uso; depende também de outros produtos concorrentes e complementares; de maneira geral, é importante

\footnotetext{
${ }^{12}$ Maiores informações sobre estes movimentos podem ser obtidos, por exemplo, em SOUZA, P. L. P. Notas para uma história do design, 2000.

${ }^{13}$ A sigla IFM neste trabalho será utilizada para designar o Institute for Manufacturing, Department of Engineering, University of Cambridge. Esta nota visa evitar a confusão entre a instituição inglesa e o Instituto Fábrica do Milênio, pelo fato da coincidência de possuirem a mesma sigla. Este último é parte do Departamento de Engenharia de Produção da Escola de Engenharia de São Carlos / Universidade de São Paulo, com sede na mesma cidade (São Carlos) e universidade (USP) onde este trabalho foi elaborado e defendido.

${ }^{14}$ No original: usable

${ }^{15}$ No original: desirable
} 
para a estética do produto que seja apropriado ao mercado, aos usuários e ao ambiente de uso; um bom teste é se os consumidores estão dispostos a pagar um prêmio [valor] porque o desejam;

(d) Produtível ${ }^{16}$ - deve ser econômico para manufatura em escala utilizando métodos apropriados de produção e considerando o impacto na organização de novos componentes, montagens e processos; deve combinar otimização de montagem e manufatura com modularidade e plataformas estratégicas;

(e) Lucrativo - deve resultar em recompensas suficientes ao negócio, mensuradas em termos de fatia de mercado, margem de lucro, empate, montante ou volume de vendas; recompensas financeiras também podem ser suplementadas por outros benefícios aos negócios;

(f) Diferenciado - os benefícios do "Bom Design" são vistos nos produtos que são claramente diferenciados; diferenciação que pode ser obtida através da satisfação de benefícios básicos dos usuários de novas formas, através da entrega de excelência em um dos atributos físicos dos produtos ou oferecendo serviços de suporte complementar aos benefícios físicos.

Neste sentido, a utilização do termo "Bom Design" neste trabalho não tenta ser normativa e estabelecer alguns produtos ou objetos como referências, como foi feito nos movimentos anteriormente citados (Good Design e Gute Form). O termo "Bom Design", como o entendido neste trabalho, refere-se às qualidades gerais de certas dimensões do produto, que deveriam ser avaliadas para, potencialmente, um produto ser bem sucedido.

\footnotetext{
${ }^{16}$ No original: producible. Relacionado à manufaturabilidade do produto, ou seja, a otimização do produto para as condições de produção disponíveis (ex.: DfMA - Design for Manufacturing and Assembly).
} 
Presta-se mais a um papel analítico que permita, justamente, sair do campo do bom gosto e das opiniões de certos grupos.

É possível considerar estas características esperadas em bons produtos como dimensões-chave, que podem então ser utilizadas para avaliar analiticamente o potencial de sucesso de um produto: benefícios centrais, qualidade da engenharia, usabilidade, desejabilidade, originalidade, produtibilidade, lucratividade ${ }^{17}$ (MOULTRIE e FRASER, 2004).

As dimensões "usabilidade" e "desejabilidade" são relacionadas diretamente ao que pode ser chamado de macro-dimensão PERFORMANCE DE INTERFACE. As dimensões “qualidade da engenharia" e "produtibilidade" são essencialmente relacionadas ao que pode ser chamado de macro-dimensão PERFORMANCE TÉCNICA. As dimensões "benefícios centrais", "originalidade" e "lucratividade" são relacionadas aos dois tipos de performance de tal forma que é difícil atribuir a uma ou outra maior ou menor influência, embora para alguns tipos de produtos isto seja possível. De qualquer forma, este tipo de relacionamento se deve mais a avaliação analítica do que a qualquer outro propósito, uma vez que, enquanto fenômeno de percepção por parte do usuário, acontece de forma global.

A discussão realizada até o momento permite argumentar, com razoável segurança, que para competir saudavelmente nas condições do mercado atual, é desejável que os produtos sejam projetados objetivando tanto a performance técnica quanto a performance de interface com seres humanos. Isto pressupõe que, no processo de desenvolvimento de produtos (PDP), estejam representadas as áreas do conhecimento que respondem pelo projeto destas macro-dimensões dos produtos.

\footnotetext{
${ }^{17}$ No original, respectivamente: core benefits, engineering quality, usability, desirability, novelty, producibility, profitability.
} 


\subsubsection{Dois tipos de design: engineering design e industrial design}

Design é um termo da língua inglesa com significado amplo, causando confusão terminológica. É tanto um verbo, indicando a ação de projetar, configurar, agir intencionalmente para atingir um objetivo, como um substantivo, designando o resultado do processo de projeto, o produto, a configuração final.

Atualmente, o cognato design já foi incorporado aos dois maiores dicionários da língua portuguesa, na falta de um termo nesta língua que compreenda adequadamente seu significado $^{18}$. A despeito disso, para maior precisão terminológica, deve-se fugir no significado dado ao termo na linguagem coloquial no Brasil, onde design é entendido como sinônimo de beleza, como um tratamento cosmético superficial, como algo que se adiciona ao produto - como na expressão coloquial comum "produto com design" - ou como em expressões do tipo "hair designer" ou "cake designer", estranhas mesmo na língua inglesa, que podem ser vista em letreiros de estabelecimentos comerciais espalhados pelo Brasil.

Na perspectiva deste trabalho, o termo se aplica às diversas áreas do conhecimento e profissional (bem como ao departamento e função na empresa) especialmente àquelas que têm por objetivo primário projetar o ambiente artificial configurado intencionalmente pelo homem, como a arquitetura e as engenharias. Mais especificamente, este trabalho trata de dois tipos de design, da forma como compreendidos internacionalmente na língua inglesa:

(i) o Engineering Design, denominado, de agora em diante, como engenharia de produto $^{19}$, ou, simplesmente, engenharia;

\footnotetext{
${ }^{18}$ Por este motivo o termo design não é grafado em itálico neste trabalho.

19 Tem-se ciência que Engineering Design tem uma abrangência mais ampla, não apenas o projeto de produtos. Neste trabalho, dada a sua natureza investigativa relacionada ao universo do desenvolvimento de produtos, será utilizada a noção de engenharia de produto, mesmo que o termo seja mais amplo.
} 
(ii) o Industrial Design, denominado, de agora em diante, design industrial, ou, simplesmente, design ${ }^{20}$.

O primeiro relacionado à área do conhecimento científico e tecnológico responsável por projetar os aspectos dos produtos que podem ser condensados sob a macro-dimensão de performance técnica; o segundo, à área do conhecimento e prática profissional responsável por projetar as características dos produtos que podem ser condensados na macro-dimensão performance de interface.

No Brasil, o termo design normalmente é utilizado sem o caracterizador "industrial", englobando outras áreas do design, como gráfico, moda, móveis, embalagens. O curso superior é denominado Desenho Industrial - numa tradução equivocada do termo da língua inglesa Industrial Design na década de $60^{21}$ - embora recentemente o MEC tenha permitido a utilização do anglicismo design. Normalmente, os cursos superiores são divididos em duas grandes habilitações: Projeto de Produto e Programação Visual. Para este trabalho, Design Industrial será utilizado como o compreendido no Brasil como habilitação em Projeto de Produto, partindo do pressuposto da existência de certa equivalência entre a noção de Industrial Design internacional e a habilitação Projeto de Produto nacional.

TOVEY (1997, p.6), coloca que:

"Design industrial é, claro, apenas um tipo de design. Tem muito em comum com a Arquitetura e com as várias versões de design da Engenharia. De fato, a relação entre Design Industrial e Engenharia Mecânica e de Produção é similar àquela desfrutada (se esta é a palavra certa) por arquitetos e engenheiros civis. Na tradição

\footnotetext{
${ }^{20} \mathrm{Na}$ Europa é utilizado Engineering Design, para o conjunto de disciplinas que embasam as engenharias (mecânica, elétrica, eletrônica, produção, etc) destinadas ao projeto, objetivando a performance técnica. Industrial Design é utilizada para a área do conhecimento e prática profissional do projeto objetivando a interface com os seres humanos. Ainda existe uma área dual, principalmente no ensino universitário, denominada Industrial Design Engineering, que prepara profissionais capacitados para atender a ambas as dimensões. Ainda existem áreas como Product Design e outras, mas não pretende-se aqui definir cada uma delas.

${ }^{21}$ Maiores informações sobre a história da instalação do curso de design no Brasil pode ser encontrado em NIEMEYER, L. Design no Brasil: origens e instalação, 1998.
} 
das Escola de Artes, o Design Industrial é atribuído como uma especialização do design tridimensional, como móveis e cerâmica, e separado, por exemplo, design gráfico, de moda ou têxtil. A despeito de suas raízes, tem uma relação estrutural muito mais forte com engenharia de produto, porque ambos se preocupam com produtos manufaturados."

O assunto é complexo e é tema de muita discussão acadêmica e na prática. Carrega as vantagens das semelhanças e a tensão das diferenças entre as duas áreas. Ambas são relativas ao projeto de porções de tecnologia e de promover mudanças nas coisas feitas pelo homem (TOVEY, 1989). Mas apresentam diferenças cruciais também.

A distinção entre design industrial e engenharia é evidente a partir da definição proclamada no Relatório Fielden (MOODY, 1980, p.329): "engenharia de produto 22 é o uso de princípios científicos, informação técnica e imaginação na definição de estruturas mecânicas, máquinas ou sistemas para desempenhar funções especificadas com o máximo de economia e eficiência."

KOTLER (1998) coloca que os engenheiros são os profissionais mais indicados para orientar sobre estratégias de manufatura a serem adotadas e são responsáveis pela orientação quanto às características físicas e técnicas produtivas do produto. No desenvolvimento de produtos, a engenharia está relacionada com a pesquisa técnica envolvendo materiais e métodos de produção, por exemplo, visando um equilíbrio técnico entre as características e desempenho técnico com a redução dos custos de produção.

O papel e as especificidades das diversas engenharias são melhores definidos, compreendidos e difundidos, razão pela qual se discutirá, ao longo do trabalho, mais o design industrial em relação à engenharia.

O design industrial é alvo de muita polêmica, discussão acadêmica e conflitos na prática. Como forma de evitar discussões desnecessárias à natureza deste trabalho, serão

\footnotetext{
${ }^{22}$ No original: Engineering Design.
} 
utilizadas visões contemporâneas do design industrial e sua relação com o processo de desenvolvimento de produtos, em detrimento de um debate sobre a formação e evolução histórica ${ }^{23}$ do design industrial.

Consciente das diversas definições dadas ao design industrial, com menor ou maior amplitude, menor ou maior rigor, este trabalho adota a seguinte definição: “o design industrial é o processo de configuração e adaptação dos produtos de uso, fabricados industrialmente, às necessidades físicas e psíquicas dos usuários, ou grupos de usuários” (LOBACH, 2001).

O design industrial é, em última análise, uma atividade que busca a configuração de interfaces, o espaço onde se estrutura a interação entre o usuário, a ação e o objeto - produto, mensagem visual (BONSIEPE, 1997), intermediando a relação entre indústria e sociedade, buscando o ponto de equilíbrio entre a viabilidade técnica e econômica de produção e o atendimento das necessidades dos usuários - considerando também sua realidade sóciocultural.

WALLACE e JAKIELA (1993, p.1), pesquisadores do Departamento de Engenharia Mecânica do Massachusetts Institute of Technology (MIT), utilizam o termo design industrial para

\footnotetext{
"descrever o projeto de produtos do dia-a-dia com a intenção de produção em massa e consumo. Neste tipo de design, funcionalidade é considerada da perspectiva do usuário. Fatores humanos (human factors) e ergonomia, manufatura, estética e o estilo de superfícies visíveis são de interesse primário."
}

\footnotetext{
${ }^{23} \mathrm{O}$ design industrial começa a se delinear em consequência da Primeira Revolução Industrial, se consolidando primeiro na prática e posteriormente no ensino formal acadêmico, com a experiência da famosa escola superior alemã Bauhaus (1919-1933), com sua visão funcionalista do design. Posteriormente, adquire status de implusionador de vendas nos EUA pós-guerra (Streamlining e Styling), onde também se firma nas universidades, em parte pela migração de professores da Bauhaus alemã que imigraram para o país devido à perseguição dos nazistas. $\mathrm{O}$ design industrial se espalha pelo mundo, tanto ligado aos negócios quanto ao ensino, se colocando como uma importante área do conhecimento mundial, produzindo fenômenos como a Escola Ulm Alemã, o design italiano, o design escandinavo, o fun design, etc. Entre contestações sobre sua vertente de apoio ao consumismo e discussões sobre sua vertente funcionalista, o design industrial foi alçado ao posto de design estratégico, sendo considerado por especialistas de diversas áreas como o elemento diferenciador no mercado globalizado. Maiores informações sobre a evolução histórica do design industrial podem ser encontradas em: ARGAN (1992); HESKETT (1998); PEVSNER (1974); PEVSNER (2001); PEVSNER (2002).
} 
O industrial Basil de Ferranti (MOODY, 1980), esclarece muito sucintamente os papéis das duas disciplinas no projeto de produtos e na inovação tecnológica. A inovação tecnológica é a função de transformar o progresso feito na ciência em novos avanços técnicos, permitidos pela engenharia de produtos. O objetivo do design industrial é relacionar estes avanços técnicos às necessidades dos seres humanos. Então, ambas as áreas tem um importante papel na inovação tecnológica: uma de transformar a ciência básica em tecnologia acessível através de dispositivos técnicos fabricáveis industrialmente (produtos); outra de oferecer uma interface eficiente e eficaz entre o usuário e o dispositivo técnico.

$\mathrm{Na}$ perspectiva deste trabalho, fica claro que a engenharia está relacionada primordialmente aos aspectos de performance técnica e o design industrial aos aspectos de performance de interface dos produtos.

Interessante notar que estes diferentes aspectos do produto não precisam necessariamente ser projetados por diferentes profissionais, desde que preparados para tal empreitada, o que, diga-se de passagem, parece estar longe da realidade do Brasil. Algumas universidades da Europa, principalmente as localizadas ao norte e na Escandinávia, oferecem o curso denominado Industrial Design Engineering. Este curso oferece uma formação dual, onde é oferecida ao aluno uma formação baseada tanto nas disciplinas relacionadas às ciências exatas e tecnológicas quanto nas disciplinas relacionadas às áreas humanas, comunicação social, ciências sociais aplicadas e até mesmo psicologia (como, por exemplo, a psicologia da percepção e semântica).

O trecho abaixo de SMETS E OVERBEEKE (1994, p.175), do Departamento de Industrial Design Engineering da Universidade de Delft, Holanda, ilustra de forma elucidativa a visão integradora deste curso: 
"Industrial design engineering é uma expressão agora comum na linguagem do diaa-dia. É o nome dado, por um lado à engenharia de produto, e, por outro, ao design estético. Profissionais com formação em Industrial Design Engineering têm, portanto, necessidade de um alto grau de conhecimento técnico e tecnológico, e seu currículo se baseia pesadamente em matemática, computação e aulas de engenharia. Mas eles também têm uma necessidade real de compreender o que os produtos técnicos causam, não apenas em termos do que as pessoas podem fazer com eles (o conceito tradicional de ergonomia), mas também em termos de como as pessoas sabem o que elas podem fazer - a expressividade dos produtos ${ }^{24}$. Um carro, por exemplo, tem que ser tecnicamente seguro e tem que ser seguro do ponto de vista da ergonomia, na prevenção dos erros que podem ser executados pelas manobras do motorista. Ainda, também tem que fazer o motorista saber como agir de forma segura".

Além demonstrar uma visão integradora e formação conciliadora de áreas distintas, demonstra uma resposta da academia à importância dada nos países desenvolvidos para integração da engenharia e do design industrial, fornecendo, no âmbito da educação, uma formação que gerará profissionais capacitados a projetar produtos com as características necessárias à concretização da inovação tecnológica nas características do mercado de competição atual.

A formação mais propícia à integração dos engenheiros europeus pode ser observada na prática, recentemente, no Núcleo de Design do Parqtec São Carlos. Fruto de um convênio entre uma empresa de biopolímeros de São Carlos e o Design Center da Universidade de Eindhoven - Holanda, um engenheiro de materiais veio ao Brasil para estágio na empresa, como parte das atividades relacionadas ao programa de mestrado no seu país de origem, em materiais inovadores aplicados ao design de embalagens. Acabou passando boa parte do tempo interagindo com a equipe de design industrial e engenharia do Parqtec, que desenvolve vários trabalhos em parceria com a empresa de biopolímeros. Sob a supervisão de professor da Universidade de São Paulo (USP), o engenheiro desenvolveu atividades de projeto multidisciplinar com a equipe. A integração foi imediata, muito diferente do que geralmente

\footnotetext{
${ }^{24}$ Os autores adotam conceito similar ao conhecido como affordance, relacionado ao valores transmitidos pelos objetos que indicam "o que e como" utilizá-los, o seu propósito; também relacionado com a área de semântica dos objetos - a atribuição de significados pelos humanos.
} 
acontece quando se relacionaram com engenheiros formados no Brasil; nunca foi necessário explicar qual o papel do design industrial e sua importância e, assuntos como semântica do objeto, relação entre forma e função, testes com usuários e outros aspectos, que normalmente são incompreendidos e fruto de conflitos, faziam parte da formação do engenheiro. Embora o próprio engenheiro visitante tenha afirmado que nem todos os engenheiros na Europa tenham esta base para a integração com o design industrial, explicou que uma formação mínima é fornecida por muitos cursos e a possibilidade de aprofundamento existe no próprio departamento de engenharia, fruto de interações com departamentos de design (informação

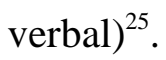

\subsubsection{Aspectos relacionados ao design industrial no projeto de produtos}

Segundo TOVEY (1989), o designer industrial tem trabalhado em equipes de projeto junto aos engenheiros de diversas áreas, especialistas em marketing, planejadores de produto, entre outros. O papel do designer industrial nas equipes de desenvolvimento de produto, tem principalmente duas áreas de responsabilidade:

- representar o mercado e os requisitos dos usuários, especificando a ergonomia e a aparência do produto;

- integrar requisitos do mercado, dos usuários e da engenharia em uma solução de projeto total.

Estas responsabilidades podem ser caracterizadas como uma preocupação com a interface produto-usuário tanto na área objetiva e mensurável denominada ergonomia quanto na área subjetiva da aparência. Para garantir que estas áreas sejam propriamente consideradas é essencial que o produto seja visto como um todo, e disto decorre sua responsabilidade pela

\footnotetext{
${ }^{25}$ Comentários retirados de entrevistas realizadas com engenheiros e designers para este estudo.
} 
integração geral da solução de projeto. Para lidar com estas áreas de responsabilidade, o designer industrial tem duas funções (não somente) principais:

- visualizar o conceito do produto;

- representar as alternativas para soluções de projeto.

O design industrial, visto por leigos e por profissionais de outras áreas, é frequentemente visto como uma atividade artística ou ligada simplesmente ao embelezamento do produto. Isto é evidente ao observar artigos acadêmicos, comentários dos empresários, dos gerentes de projeto e das equipes de desenvolvimento, inclusive em empresas de maior porte no Brasil (informação verbal) ${ }^{26}$.

Estas visões são equivocadas, embora seja compreensível que aqueles que não compreendem em profundidade tirem estas conclusões, até porque a parte mais perceptível do trabalho dos designers industriais seja a forma, invariavelmente mais "bela" aos olhos das pessoas do que as formas geradas pelos engenheiros, amadores e curiosos em geral.

Não é objetivo deste trabalho esclarecer em profundidade como o designer industrial desenvolve seus projetos. Acredita-se ser o suficiente, para os seus propósitos, afirmar que repousa em princípios provenientes de diversas áreas do conhecimento, mesmo quando na área subjetiva da criação de formas. Deve-se aceitar, por outro lado, que tais disciplinas careçam da mesma robustez matemática, física e quantitativa das disciplinas de ciência básica e aplicada que embasam as engenharias, mesmo porque alguns fenômenos relacionados se prestam a métodos mais qualitativos e menos susceptíveis a construção de modelos matemáticos que os descrevam, dada a sua natureza.

\footnotetext{
${ }^{26}$ Entrevistas realizadas para este trabalho com profissionais, engenheiros e designers, que trabalharam em grandes empresas indicam uma situação pouco integrada ou deficiente entre os departamentos de design e engenharia. A situação pareceu ser generalizada, a ponto de ser supreendente que poucos estudos sejam dedicados a investigação deste fenômeno no Brasil. Os pontos mais citados são: disputa interna interdepartamental, falta de compreensão do papel do design e o preconceito, velado ou explícito, entre as duas áreas.
} 
O design industrial tem por objetivo configurar a interface entre o produto e o ser humano, considerado na sua variedade de papéis (usuário, consumidor, membro da sociedade, por exemplo) e nos diversos níveis em que interage com os produtos. Para que esta configuração seja eficaz, busca dotar o produto de características que atendam aos diversos níveis em que esta interação ocorre, considerando os diversos papéis em que o ser humano se coloca. Não se trata somente de "fazer um produto bonito", até porque este conceito é extremamente relativo conforme variam as características dos usuários. Beleza, na forma como utilizado no senso comum, é considerado sinônimo de estética, embora este seja um equívoco reducionista. Como comumente aplicado, a beleza por si só não poderia ser utilizada isoladamente para definir um processo eficaz de desenvolvimento de interface produtousuário. Ainda assim, a estética é uma área cara ao design industrial, e, a despeito da noção leiga ou desinformada, existem estudos, teoria e regras para sua utilização mais científica, como na estética do objeto, teoria da informação, percepção estética, estética do valor, estética empírica, estética aplicada, semiótica ${ }^{27}$.

BERKOWITZ (1987), por exemplo, conclui que dicas (visuais) de design, como forma, são utilizadas por consumidores para inferir atributos mais importantes, mas menos acessíveis à leitura, como gosto, maciez, conforto e velocidade. O bom design não apenas adiciona apelo de vendas, mas encoraja a compra de produtos similares (não necessariamente mais baratos), oferece uma base para segmentação de mercado e construção de uma linha de produtos maior com o mesmo investimento em engenharia.

JANLERT e STOLTERMAN (1997) colocam que as pessoas têm o hábito de pensar e falar sobre artefatos como se tivessem caráter, como uma forma de entender e lembrar como

\footnotetext{
${ }^{27} \mathrm{O}$ conceito estético vem do grego aesthesis e significa algo próximo à "percepção sensorial". Uma definição aceita entre os estudiosos definine estética como: ciência das aparências perceptíveis pelos sentidos, de sua percepção pelos homens e sua importância para os homens como parte de um sistema sócio-cultural. Informações mais aprofundadas podem ser obtidas em LOBACH (2001).
} 
utilizá-los; elas tendem a assumir uma conexão entre a mera aparência do artefato e seu caráter, da mesma forma com que fazem, marcadamente, pressuposições sobre uma pessoa ser generosa ou egoísta, boa ou má, inteligente ou estúpida, etc, meramente com base nas suas características faciais. Um designer explora estas dependências entre aparência e caráter percebido. No campo de semântica do produto, diversas abordagens são embasadas em várias interpretações no pressuposto que certas formas, padrões e símbolos criam certas emoções e associações no usuário. Tal conhecimento é obviamente útil aos designers industriais. Este conhecimento não é limitado apenas ao campo visual, mas também nos outros sentidos.

BONSIEPE (1997) recorre ao termo interface para estabelecer o espectro de atuação do design industrial. A interface é o espaço onde se articulam e se estrutura a interação de três campos heterogêneos: (i) um corpo humano; (ii) um objeto, uma ferramenta ou uma informação (no caso de uma ação comunicativa); (iii) o objetivo da ação.

O produto é um dos componentes considerados pelo design industrial, considerando que seu objetivo é dotar o produto de características que permitam configurar uma interface adequada, isto é, que permita ao ser humano, considerado tanto física quanto psicologicamente, utilizar aquele objeto da forma mais eficiente e eficaz possível para realizar a ação desejada. Em última análise, todo design é design de interface.

\footnotetext{
"Artefatos são objetos para possibilitar ações efetivas. A interface [...] é o tema central do design. A interface permite explicar a diferença entre engenharia e design. No entanto, ambos são disciplinas projetuais. O design visa os fenômenos de uso e da funcionalidade de uso. No centro do seu interesse se encontra a eficiência sociocultural na vida cotidiana. As categorias da engenharia, porém, não captam os fenômenos de uso, ou seja, a integração dos artefatos à cultura cotidiana. Elas recorrem ao conceito de eficiência física, acessível aos métodos das ciências exatas que não captam os fenômenos de uso.” (BONSIEPE, 1997, p.17).
} 
LOBACH (2001) considera que o design industrial deve considerar três níveis de funções dos produtos (em relação à interação com os usuários) no processo de configuração da interface: (1) funções práticas; (2) funções estéticas; (3) funções simbólicas:

(1) A função prática relaciona-se à adaptação do produto às necessidades fisiológicas dos usuários. As áreas conhecidas como ergonomia, tanto física quanto cognitiva, e usabilidade, são preponderantes para o projeto desta função.

(2) A função estética é relacionada à adaptação do produto às características de percepção dos usuários, tanto em seu âmbito psico-fisiológico inato quanto às de experiência estética influenciadas por fatores do ambiente.

(3) A função simbólica é relacionada à configuração do produto de forma a atender às necessidades cognitivas, sociais e de atribuição de significados aos produtos pelos usuários.

Áreas do conhecimento como a psicologia da percepção, semântica do objeto, estética aplicada, empírica e do valor, entre outras, são utilizadas no projeto destas duas últimas.
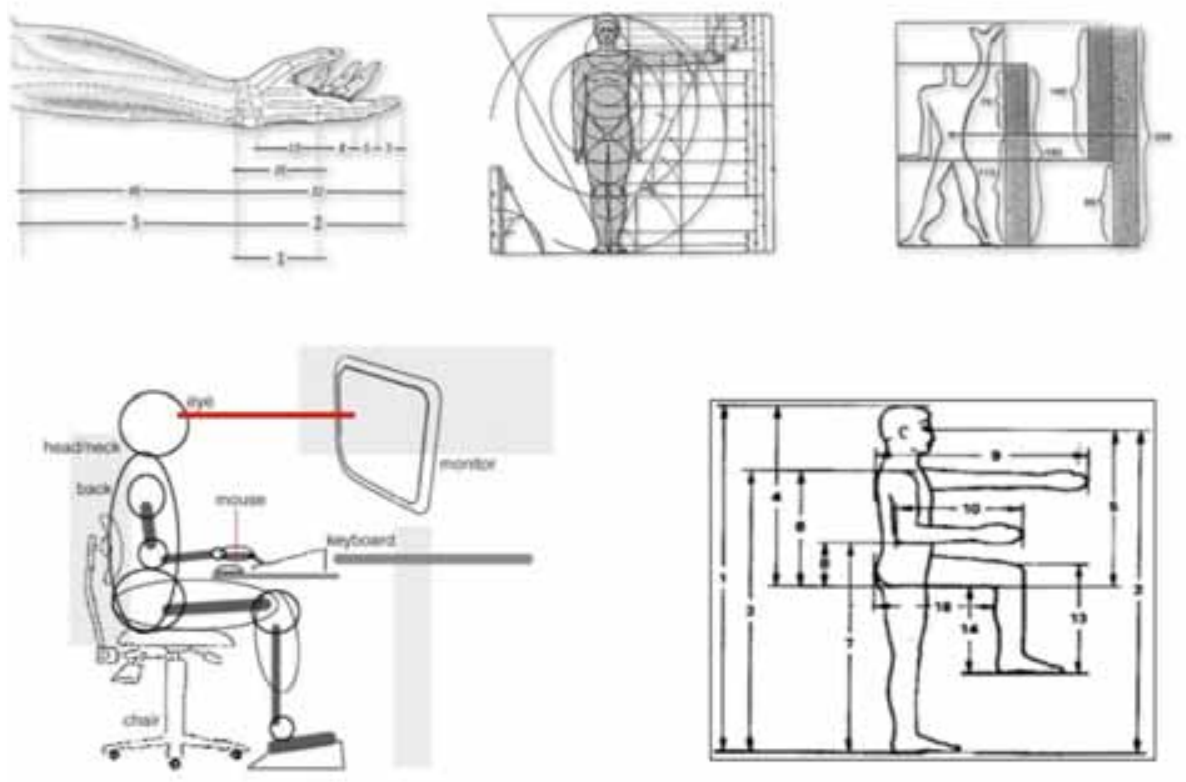

Figura 2.3 - Exemplos de diagramas para estudo e adaptação da ergonomia física 


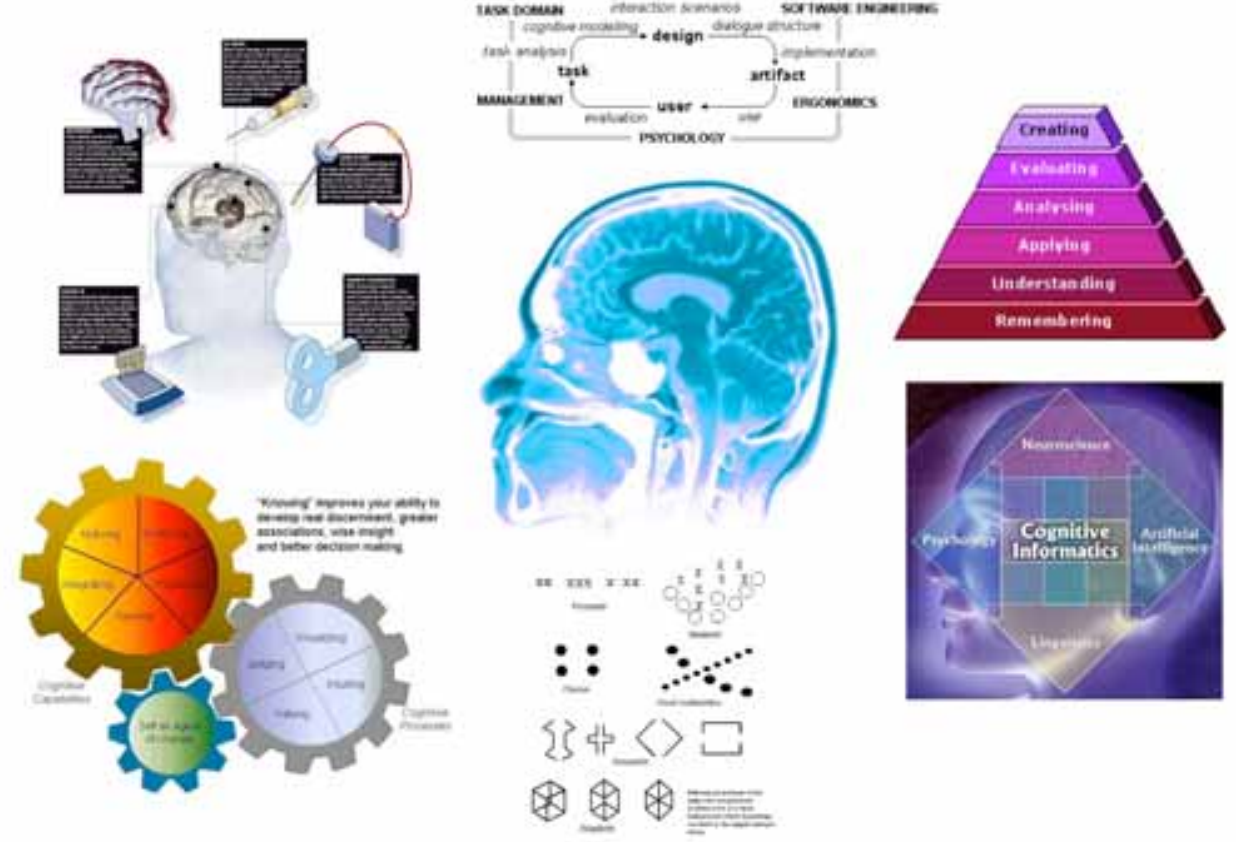

Figura 2.4 - Exemplos ilustrativos relacionados à ergonomia cognitiva

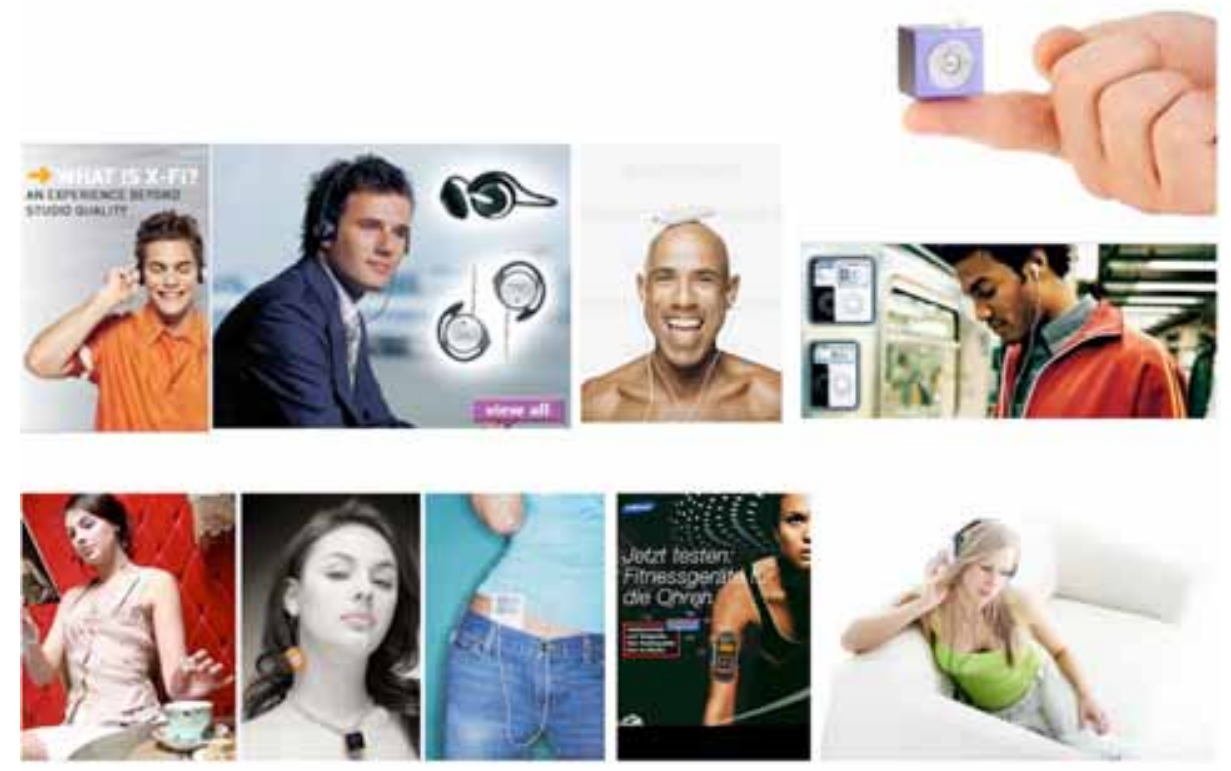

Figura 2.5 - Exemplo ilustrativo de um "quadro de estilo de vida" para análise de valores simbólicos

Estas funções não são estanques, dependendo e se influenciando mutuamente, variando de importância de acordo com o tipo de produto, sua aplicação e seu contexto de comercialização e uso, mas nunca se anulando completamente. 
A forma final propriamente do produto acaba por concentrar todas as três funções, tanto à primeira vista (visualmente, sonoramente, tactilmente) quanto no processo de uso, pois, em última análise, é a configuração morfológica do produto que permite que o artefato se conecte ao ser humano. Isso não significa que a forma foi determinada sem critérios e objetivando somente a estética, mas que é o resultado de exigências e diretrizes de projeto, ancorados nos diversos níveis de necessidades relacionadas às funções, condensadas numa configuração espacial. Recair neste equívoco - muito comum - é o mesmo que afirmar que um avião foi projetado baseado apenas em estética porque apresenta formas elegantes e agradáveis ao olhar, e não em diretrizes complexas de engenharia provindas das diversas disciplinas necessárias para se projetar as diversas funções que permitem que um artefato mais pesado que o ar levante vôo.

CREUSEN e SCHOORMANS (2005) realizaram amplo estudo quantitativo com objetivo de observar se a forma de um produto realmente influencia o processo de escolha do consumidor e quais seriam estas formas de influência. Segundo o artigo, a aparência do produto influencia o processo de escolha e desempenha seis papéis na avaliação que o consumidor faz do produto: (i) comunicação estética; (ii) simbólica; (iii) funcional; (iv) informação ergonômica; (v) enquadramento da atenção; (vi) categorização. A aparência do produto pode ter valor estético e simbólico para o consumidor, pode comunicar características funcionais e fornecer impressão de qualidade (valor funcional) e pode comunicar facilidade de uso (valor ergonômico). Ainda, pode focalizar a atenção e pode influenciar a facilidade de categorização do produto. Desta forma, recomendam que estes papéis e sua influência sejam utilizados por gerentes de desenvolvimento de produtos para aperfeiçoar o produto para melhor atender às necessidades de mercado. 
Na perspectiva deste trabalho, uma vez que é necessário que os produtos alcancem boa performance técnica e de interface para obterem maior chance de sucesso no mercado, é essencial que o design industrial e a engenharia, responsáveis por projetar estes aspectos nos produtos, respectivamente, se relacionem e se integrem adequadamente. A arena onde esta integração acontece é o processo de desenvolvimento de produtos (PDP).

\subsubsection{Processo de Desenvolvimento de Produtos (PDP)}

As mudanças impostas pela globalização tornaram o mercado mais competitivo. Neste contexto, a importância do Processo de Desenvolvimento de Produtos (PDP) aumentou consideravelmente, pois o sucesso no lançamento de novos produtos confirmou-se como uma clara vantagem competitiva. Atingir este sucesso significa lançar produtos com maior rapidez, qualidade e menores custos (VALERI et. al., 2000). Na perspectiva deste trabalho, também significa projetar produtos que contemplem os atributos relacionados à performance de interface.

O PDP é objeto de análise de uma ampla variedade de estudos, sob diversos pontos de vista, profundidades e abordagens, provavelmente como uma resposta da academia à demanda do setor produtivo, face ao acirramento da competição.

Para se manterem competitivas, as empresas buscam adotar filosofias como a Engenharia Simultânea (ES) no processo de desenvolvimento de produtos, focando somente seus aspectos organizacionais ou investindo na integração de sistemas do tipo CAD / CAE / CAPP (Computer Aided Design / Computer Aided Engineering / Computer Aided Process Planning) para compartilhar um único modelo de produto (ROZENFELD e SILVA, 1998). A ES tem sido preferida em relação à abordagem sequencial tradicional, onde cada fase deve terminar para que se inicie a próxima. 
ROZENFELD (1995) define Engenharia Simultânea como a filosofia utilizada no PDP, com base na sinergia entre seus agentes, suportados por recursos e métodos integrados, visando: um aumento da qualidade do produto com foco no cliente; uma diminuição no ciclo de desenvolvimento e uma consequente diminuição dos custos.

O conceito de desenvolvimento de produtos como um processo passou a ser utilizado de forma a permitir a implantação adequada da filosofia de ES. CARTER e BAKER (1992) e CLAUSING (1994), entre outros, também apresentam definições de Engenharia Simultânea através uma visão por processos.

CLARK \& FUJIMOTO (1991) definem desenvolvimento de produto como “ (...) o processo pelo qual uma organização converte dados sobre oportunidades de mercado e possibilidades técnicas em bens e informações para fabricar um produto comercial."

Este processo deve ser eficiente, considerando a importância do desenvolvimento de produtos na competição atual, garantindo tanto a qualidade do produto final quanto do próprio processo. Para isso, a implementação de Gate Systems tem sido adotada.

Os Gate Systems são modelos conceituais e operacionais com o objetivo de controlar o processo de desenvolvimento de novos produtos desde a idéia até o seu lançamento. Gates são revisões gerenciais estruturadas em pontos críticos do projeto de novos produtos, com o objetivo de rever as atividades do projeto, avaliá-lo a partir da perspectiva do negócio e decidir se o projeto continuará, se será redirecionado, se será adiado ou mesmo cancelado. $\mathrm{O}$ projeto só tem continuidade se obtiver aprovação nos Gates (VALERI et. al., 2000).

Cada vez mais o desenvolvimento de produtos tem sido visto além das fases onde acontecem as decisões sobre o projeto do produto em si, abarcando também atividades relacionadas à definição de qual produto deve ser desenvolvido, por exemplo, e como este se 
adequa à estratégia geral e/ou comercial da empresa. Desta forma, pode-se falar em gestão do processo de desenvolvimento de produtos como um processo de negócio que ocorre no contexto organizacional.

ROZENFELD et. al. (2006) divide o PDP em basicamente em 3 macro-fases (ver Figura 2.6): pré-desenvolvimento, desenvolvimento e pós-desenvolvimento, descritas brevemente em seguida.

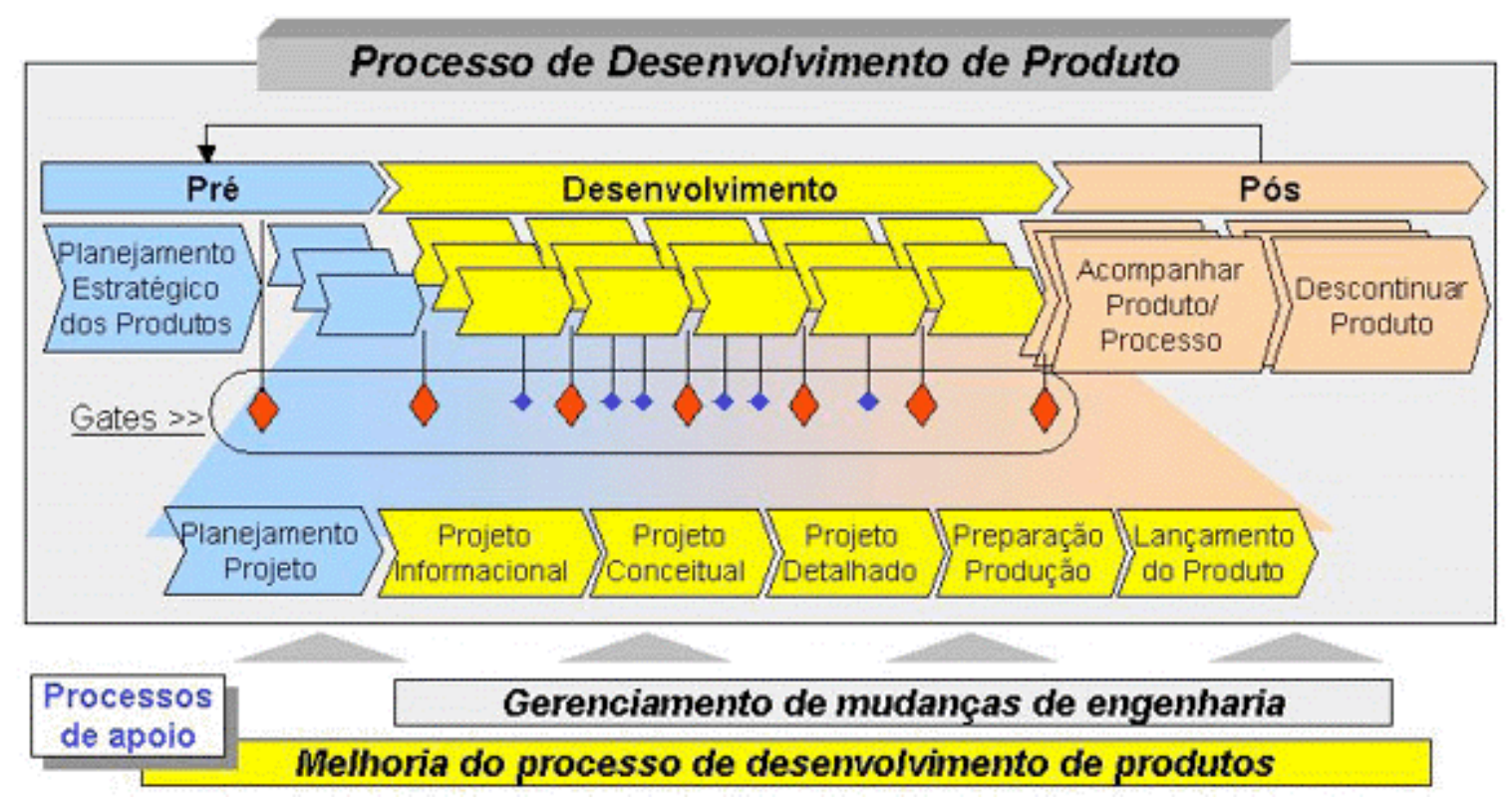

Figura 2.6 - Visão geral / Modelo de Referência do PDP

FONTE: ROZENFELD et. al., 2006

(I) Macro-fase "Pré-Desenvolvimento" - onde acontece a definição do produto a ser desenvolvido, isto é, a definição do escopo do projeto de desenvolvimento (equipe, resultados, restrições, etc), avaliação econômica do projeto, avaliações de capacidade e risco do projeto, definição de indicadores para monitoramento do projeto e definição de planos de negócio. É o que se denomina no modelo de fase de "Planejamento do Produto". Como se trata de um processo integrado com a missão e direcionamento estratégico da empresa, esta macro-fase considera a possibilidade da criação de uma família de produtos. Assim, há uma 
fase anterior ao "Planejamento do Produto" denominada "Planejamento Estratégico do Produto". Ela consiste na revisão do planejamento estratégico da empresa e seu desdobramento gerando um "Portfolio de Produtos" capaz de atingir as metas definidas neste plano. Neste portfolio constarão os produtos que precisarão ser desenvolvidos, incluindo uma descrição inicial de suas características e a definição acerca do tipo de projeto, por exemplo, se é um projeto totalmente novo, uma atualização ou parte de uma família de produtos. No portfolio consta também a data na qual se dará início a fase de planejamento de cada um dos produtos.

(II) Macro-fase "Desenvolvimento" - agrega as atividades técnicas do desenvolvimento de produtos em si, o projeto do produto propriamente dito, onde tomam parte as atividades mais técnicas, numa perspectiva de stage-gates:

1 - Projeto Informacional - é feita a aquisição de toda uma gama de informações sobre o tema do projeto em questão e sua posterior interpretação. Os procedimentos de projeto recaem, principalmente, no levantamento junto aos clientes, das necessidades e desejos a serem atendidos pelo projeto, além das características do processo produtivo e suas restrições Estas necessidades são analisadas e então transformadas em especificações técnicas a serem seguidas pelo projeto;

2 - Projeto Conceitual - com base nas informações obtidas na fase anterior de projeto é proposto o conceito a ser adotado pelo produto. É realizada, uma síntese da estrutura de funções a serem desempenhadas pelo produto, a busca de princípios de soluções para cada uma destas funções, a subseqüente proposição de alternativas de projeto e, finalizando, a seleção daquelas que possuam uma maior concordância com as necessidades do consumidor, levantadas na fase anterior; 
3 - Projeto Preliminar - conhecendo-se o conceito e a estrutura funcional do produto pode-se dimensioná-lo, selecionando-se materiais, formas, componentes, processos de fabricação e montagem, etc. Esta fase possui um caráter mais iterativo, uma vez que uma única alteração em um componente pode levar a diversas outras alterações em outras partes do produto. Ao final desta fase, os produtos estão totalmente estruturados.

4 - Projeto Detalhado - a disposição, a forma, as dimensões e as tolerâncias dos componentes são finalmente fixadas, juntamente com a definição e planejamento dos processos de produção. São confeccionados protótipos e cabeças de série, avaliados e, finalmente, validados. ${ }^{28}$

(III) Macro-fase "Pós-Desenvolvimento" - ocorre inicialmente um planejamento de como o produto será acompanhado e retirado do mercado. Deve-se definir as equipes e recursos necessários para as alterações de engenharia, visando correções de potenciais falhas e/ou adição de melhorias requisitadas pelos clientes. Definem-se também metas e índices que indicam quando o produto deverá ser retirado do mercado. Ao final deste planejamento, inicia-se a fase de acompanhamento e melhoria do produto, onde estas equipes realizam a manutenção e aprimoramento do produto, com especial atenção para a sistematização de conhecimentos e melhores práticas de projeto que deverão alimentar todos os profissionais envolvidos com o desenvolvimento. Esta fase dura até o momento que o produto atinge suas

${ }^{28}$ Estas fases não são estanques e, na prática, muitas atividades se sobrepõem, ainda mais devido à aplicação dos métodos de engenharia simultânea. As fases de projeto conceitual, projeto preliminar e projeto detalhado acontecem em grande parte em sistemas de projeto por computador (CAD/CAE, etc), no que é chamado por alguns autores de Virtual Product Development (VPD). Desta forma, definir onde terminam e começam as atividades de cada fase se deve mais para o estudo, no caso da academia, e para o controle e melhoria do processo, no caso das empresas, do que uma divisão que existe na prática. A própria bibliografia utilizada comenta que a fase Projeto Preliminar, entre a fase Projeto Conceitual e Projeto Detalhado "era realmente algo necessário quando o desenvolvimento de produto se fazia pouco uso de sistemas CAD. (...) Hoje em dia, com a existência de sistemas CAD mais sofisticados e baratos; o conceito de gates técnicos e gerenciais; a flexibilidade de escopo do Projeto Conceitual (...) não necessita mais de uma fase formal de Projeto Preliminar.” (ROZENFELD et. al, 2006, p.298). Mesmo assim, optou-se por manter aqui a descrição da fase, enquanto conceito. 
metas e a equipe que gerencia o portfolio de produtos decide descontinuá-lo. Inicia-se então a fase de Retirada do Produto do Mercado, onde será realizado o encerramento oficial do projeto e serão tomadas todas as providências relativas ao descarte ambientalmente correto, destinação dos estoques de peças e produtos, auditoria para balanço geral dos conhecimentos adquiridos com o produto e arquivamento correto das informações do produto.

ROZENFELD e SILVA (1998) colocam que o PDP deveria ser considerado através de uma visão holística, evitando distorções entre as visões especialistas daqueles que dele participam, baseando-se na visualização da empresa como uma coleção de Business Process (BP). Um BP é constituído por um grupo de atividades que é manipulada e conectada através de informações, utilizando-se dos recursos da organização. Forma uma unidade coesa e que deve ser focado em um negócio. Este negócio por sua vez é geralmente focado em um mercado ou cliente específico, com os respectivos fornecedores.

O Institute for Manufacturing (IfM) do Departamento de Engenharia da Universidade de Cambridge, Inglaterra, adota a nomenclatura New Product Development - NPD (Desenvolvimento de Novos Produtos). Este processo é dividido em dois níveis principais (IFM, 2007):

(i) Processo de Desenvolvimento de Produtos - foca nas atividades de seleção, avaliação e definição do portfolio de produtos e nas atividades de estruturação, gerenciamento, controle e organização do processo como um todo;

(ii) Processo de Projeto do Produto - a sequência de atividades de design e engenharia decisões de progresso da idéia à solução detalhada; refere-se ao projeto do produto em si; é essencialmente iterativo e envolve a definição do problema, obtenção e codificação de informação relevante, busca divergente por soluções, convergência na solução preferida e otimização e implantação detalhada. 
A figura 2.7 representa o modelo proposto pelo IfM. Consiste de seis fases, do projeto e definição de produto até a obsolência. Inclui uma geração contínua de projeto para representar atividades em andamento das empresas, como negócios, tecnologia e estratégia de marketing, que são essenciais para gerar novos projetos. O processo é desenhado com as fases deliberadamente se sobrepondo para indicar a natureza iterativa do desenvolvimento.

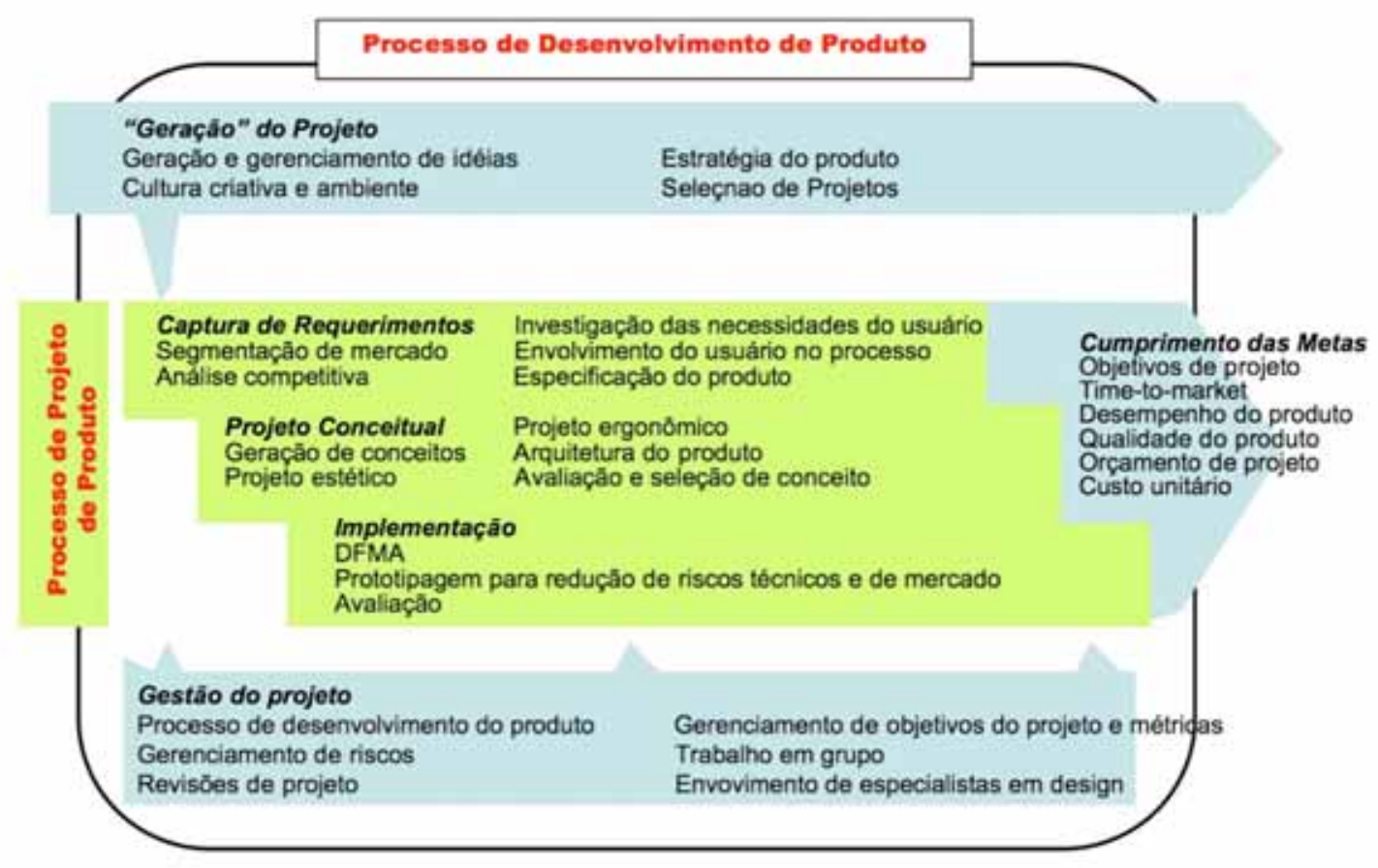

Figura 2.7 - Visão genérica do New Product Development - IfM

FONTE: adaptado de IFM, 2007

O Processo de Projeto de Produto tem escopo mais restrito do que o Processo de Desenvolvimento de Produto, e não se preocupa com as questões de gerenciamento e controle.

As áreas verdes, da forma como considerado pelo IfM se assemelham ao considerado por ROZENFELD et. al. (2006) como macro-fase "Desenvolvimento", onde as decisões relativas à oportunidade de mercado, o portfolio de produtos, viabilidade global, entre outras, 
já foram consideradas. Refere-se, desta forma, ao desenvolvimento do produto propriamente dito, onde as atividades e decisões de engenharia tomam lugar.

Ao longo deste trabalho, será utilizada a nomenclatura Processo de Desenvolvimento de Produtos (PDP), referindo-se essencialmente à macro-fase "Desenvolvimento" e/ou fase Processo de Projeto de Produto, uma vez que as atividades relativas à gestão, gerenciamento e controle são menos relevantes ao objeto de estudo deste trabalho e menos sujeitas à análise através do método utilizado.

Existem diversos pontos de vista e muitas metodologias referenciais para desenvolvimento de produtos, considerando, inclusive, as diferenças cruciais existentes entre os modelos de engenharia e design industrial. Dada a natureza deste trabalho, as fases são consideradas genericamente, considerando que, apesar das diferenças entre modelos, existe certo consenso em relação às fases genéricas.

Independentemente do modelo de PDP e definição de design industrial e engenharia de produtos adotados, designers industriais e engenheiros parecem trazer ao processo diferenças de tal ordem que sua integração pode necessitar de medidas específicas para sua adequada integração. As próximas páginas buscam realizar uma varredura da literatura com o objetivo de identificar e relacionar esta problemática.

\subsection{CONTORNOS DO FENÔMENO DA INTEGRAÇÃO ENTRE DESIGN E ENGENHARIA}

A despeito dos estudos acadêmicos e dos casos de sucesso fornecerem fortes evidências sobre a importância de integrar o design industrial à engenharia no PDP, os mesmos estudos e a realidade prática apontam para algumas dificuldades, incluindo um grau de negligência para com este tipo de abordagem. Também indicam, uma vez tendo a empresa 
resolvido optar pela integração, diversas dificuldades na integração prática entre designers industriais e engenheiros no PDP. Estas dificuldades parecem acontecer tanto nos países desenvolvidos quanto no Brasil.

Este trecho sintetiza preliminarmente esta situação:

\begin{abstract}
"Há incerteza no lançamento de um novo produto. As descobertas [...] indicam que o sucesso (ou fracasso) comercial é normalmente determinado por um conjunto de fatores. Se existe competição, a performance técnica sozinha não trará o sucesso. Mesmo assim, muitas empresas destinam uma grande parcela dos seus recursos no desenvolvimento daqueles fatores relacionados à tecnologia e lidam com as preferências não-técnicas dos usuários de uma forma muito superficial. [...] O design industrial pode aliviar a incerteza que acompanha a inovação tecnológica." (MOODY, 1980, p.331, grifo nosso).
\end{abstract}

A literatura internacional apresenta alguns estudos sobre o assunto, sendo que a maioria deles aponta dificuldades mais profundas nas empresas de pequeno porte. Obviamente, os estudos variam quanto ao país, setor e tipo de empresa, metodologia, amostragem, intensidade dos problemas encontrados e causas apontadas. Entretanto, é possível afirmar que a falta de conhecimento sobre o que é design industrial, a sua contribuição e o seu papel no desenvolvimento de produtos são relacionados como fatores críticos por vários estudos (CDI, 2007; DESIGN COUNCIL, 2004; MOODY, 1980; MOULTRIE; FRASER; CLARKSON, 2002; MOULTRIE e FRASER, 2004; NAEH \& DDC, 2003; IFM, 2007).

A literatura nacional é escassa em relação à uma abordagem direta e específica sobre o assunto da integração entre design e engenharia. Destaque deve ser dado: à Universidade Federal do Rio Grande do Sul - UFRGS, que possui ações para integração entre design e engenharia (de materiais), como o Laboratório de Design e Seleção de Materiais, além de artigos publicados especificamente sobre integração entre design e engenharia (KINDLEIN, 
2006); à FERREIRA et. al. (2003) que publicou artigo sobre o assunto, embora pareça ser uma iniciativa mais isolada.

De uma forma geral, os parcos estudos existentes são concentrados essencialmente nas engenharias de produção e versam sobre gestão do design, não avançando nas questões mais profundas em relação à integração das duas áreas no PDP, não se utilizando de casos reais de desenvolvimento de produtos em profundidade e não utilizando ferramentas mais robustas para uma análise menos qualitativa ${ }^{29}$.

Considerando a carência de estudos específicos sobre o tema e orientando-se pela problemática inferida a partir da prática, esta parte do trabalho articula literatura de diversas áreas, numa tentativa de delinear os contornos do fenômeno da integração entre design industrial e engenharia no processo de desenvolvimento de produtos, buscando identificar as dimensões que o influenciam.

\subsubsection{As especificidades das pequenas empresas}

As empresas são o palco principal onde ocorre a integração entre design e engenharia. Entre as diversas variáveis que as caracterizam, provavelmente o porte ("tamanho"), seja o mais preponderante. A literatura de diversas áreas - especialmente a relacionada à Administração - vem apontando com cada vez mais contundência a necessidade do desenvolvimento de abordagens específicas para o porte das organizações, especialmente diferenciando as empresas de pequeno e grande porte.

\footnotetext{
${ }^{29}$ Não se trata aqui, de uma crítica à pesquisa qualitativa em si - até porque o presente estudo se enquadra neste tipo - mas em buscar ferramentas metodológicas que possam avançar em uma direção mais robusta. Uma crítica comum aos artigos da área de design é que são demasiadamente qualitativos e, em alguns casos, chegando a uma região fronteiriça da ciência, baseando-se exclusivamente em evidências anedóticas, opiniões pessoais e carecendo de maior precisão terminológica e metodológica para fundamentar suas conclusões.
} 
As empresas de pequeno porte são a maioria das empresas em todos os países do mundo e são responsáveis pela maioria dos empregos. Constituem um domínio de estudo em si e devem ser analisadas assim (JULIEN, 1997).

ESCRIVÃO FILHO et. al. (2005) argumenta que se deve considerar como pressuposto que temas retirados da Teoria Administrativa para grandes empresas são indicativos de boa gestão nas pequenas empresas também, embora não se manifestem necessariamente da mesma forma e grau. Estas variações das manifestações dos temas organizacionais na pequena empresa podem ser consideradas como as "especificidades organizacionais" das pequenas empresas. Durante muito tempo pensou-se que as pequenas empresas deveriam utilizar os mesmos princípios de administração das grandes empresas. Isso se deve ao fato de utilizarem o que ficou conhecido como paradigma da "Pequena Grande Empresa", na qual a pequena empresa seria uma grande empresa que não havia crescido. Desta forma, as pequenas empresas possuem particularidades que as diferem das grandes empresas, resultantes principalmente de limitações relacionadas ao seu porte - como limitações financeiras e de recursos humanos - constituindo-se como uma área de estudo particular, necessitando de uma teoria específica.

Esta visão da pequena empresa como um objeto particular de estudo, onde se manifestam fenômenos específicos relacionados com o seu porte, é corroborada pelas observações de MOULTRIE, CLARKSON e PROBERT (2007) em relação ao desenvolvimento de produtos. Estes autores realizaram estudo para desenvolver uma ferramenta de auditoria do processo de design especificamente para pequenas e médias empresas, apontando que: 
(i)

a pesquisa de desenvolvimento de produtos tem geralmente focado em grandes empresas, existindo escassos estudos sobre como as pequenas e médias empresas podem incorporar estes princípios e práticas de inovação;

(ii) pequenas empresas devem adotar abordagens diferentes para gerenciar o desenvolvimento de produto em relação às grandes organizações;

(iii) pequenas empresas enfrentam limitações significantes de recursos humanos e financeiros;

(iv) a equipe de profissionais das pequenas empresas pode ter menos preparação em relação aos profissionais das grandes empresas;

(v) o trabalho em times multidisciplinares pode ser inibido por hostilidades tribais $^{30}$ profundamente enraizadas e ressentimento entre designers, engenheiros e profissionais de marketing;

(vi) o custo percebido de empregar um profissional de design é, na maioria dos casos, visto como proibitivo; a despeito da falta de profissionais internos, as empresas são relutantes em buscar ajuda externa.

A literatura sobre a integração entre design e engenharia em empresas de grande porte no Brasil é praticamente inexistente. Porém, existem evidências oriundas do contato prático com departamentos de design e engenharia em grandes empresas brasileiras, que indicam uma dinâmica problemática, permeada por rivalidades, discordâncias, incompreensão, preconceitos, enfim, falta de integração. Os trechos abaixo, retirados de entrevistas com dois

\footnotetext{
${ }^{30} \mathrm{O}$ autor parece se valer do conceito sociológico sobre a necessidade do ser humano de participar de um grupo, o que o conduz a compartilhar e defender, genuinamente ou por pressão social, seus valores grupais e se opor a participantes de outros grupos de forma mais ferrenha e irracional do que faria isoladamente.
} 
engenheiros mecânicos a respeito da relação entre design e engenharia em grandes empresas

que trabalharam, ilustram a situação:

"O departamento de design da empresa $\mathrm{X}$ é grande, com uns quinze designers. Eu trabalhava na engenharia, e não tinha problemas com os designers, mas a maioria dos engenheiros não aceitava de forma alguma o que vinha de lá. Comentavam que o pessoal do design queria mandar no que seria desenvolvido. Tínhamos muitos problemas, inclusive de preconceito de ambos os lados."

"Trabalhei na empresa Y por um ano. O departamento de design era um problema. Trabalhavam lá uns cinco designers, formados e tudo. Mas era um tal de passar o projeto para lá e para cá: os engenheiros reclamavam que o que os designers propunham era difícil de produzir, os designers reclamavam que os engenheiros eram quadrados." (informação verbal).

Nas empresas de pequeno porte, que não possuem a capacidade de incorporar grandes

equipes nem despender recursos da ordem das grandes empresas, existem evidências de uma

situação ainda menos propícia para integração entre estes profissionais. LUZA (2003, p.33-

34), em estudo sobre a indústria moveleira, analisa que:

"Na indústria moveleira, então, o design praticamente não está presente, pelos motivos já expostos e são as grandes empresas que utilizam os serviços de um designer. (...) A realidade apresentada por uma pesquisa realizada pela Confederação Nacional da Indústria, com associações setoriais nacionais, cujo objetivo era fornecer informações gerais sobre aspectos da gestão do design, é um pouco diferente, mas que não deixa de reforçar a idéia de que praticamente são as grandes indústrias que utilizam o design durante o desenvolvimento de seus produtos. (...) Já as micro e pequenas preocupam-se mais - ou acreditam ter somente esta solução - em copiar produtos que "deram certo", sendo este de custo menor. Portanto, ainda hoje, 2003, é possível ver indústrias moveleiras que estão buscando produtos já existentes, que são bons aos seus olhos e aos do consumidor, e, aí, adaptam alguns detalhes, não se preocupando em utilizar o design no desenvolvimento de produtos. Então, no que concerne ao design propriamente dito, não há quase inovações; o que existe é a preocupação com acabamentos, com ferragens, com a legislação fiscal e como produzir um produto mais barato, haja vista que a forma e a estética utilizada é aquela que o comércio internacional utilizou há dez anos atrás, pois isso agrada ao brasileiro. (...) Mas, pela prática que se tem no setor moveleiro, percebe-se que alguns empresários apresentam uma resistência em procurar profissionais de design para a indústria dele. Analisando-se o referencial teórico, constata-se que estes empresários ainda acreditam que o profissional designer é "modismo", que é coisa para a elite, que custa caro e que o designer é mais um adorno, um enfeite dentro da empresa dele."

TEIXEIRA (2005), ao comentar as iniciativas de promoção do design no Brasil, argumenta que, apesar da necessidade de incorporação do design nas empresas e dos 
programas de apoio, a coerência do discurso teórico encontra resistência na sua aplicação prática. No Brasil, salvo exceções, existe uma defasagem muito grande entre a teoria e a realidade dessa profissão nas empresas.

GOMEZ (2005), em estudo sobre a utilização de design industrial para exportações do setor moveleiro, conclui que as empresas, apesar de pequenas, valorizam o design, integrando em diversas fases do projeto.

Porém, como o próprio estudo indica na sua revisão bibliográfica, em relação aos recursos humanos que trabalham com o desenvolvimento de produtos dentro das empresas moveleiras:

“... a maioria das empresas selecionadas (67\%) não possui pessoal especializado em design. Quando possuem esse tipo de pessoal, em geral são empregados que apresentam apenas experiência prática, não tendo uma formação profissional na área. A exceção fica por conta das empresas líderes, que em geral possuem profissionais especializados, como arquitetos, engenheiros, desenhistas ou mesmo designers" (COUTINHO, 2001*, p. 41 apud GOMEZ, 2005).

Na mesma pesquisa, a autora mostra dados da pesquisa da CNI (1998* apud GOMEZ, 2005), que indicam que $46 \%$ dos designers que trabalham com o setor moveleiro possuem apenas o $2^{\circ}$ grau, $45 \%$ são graduados (em qualquer área) e apenas $9 \%$ possuem formação maior - especialista, mestre ou doutor (em qualquer área).

Desta forma, como em outros estudos, as empresas consultadas afirmam utilizar design, mas, quando realizada uma análise mais detalhada, observa-se, como o demonstrado acima, que não são utilizados designers profissionais. Em muitos casos, como o comentado por um profissional do Núcleo de Design/Parqtec, "as empresas, na maioria das vezes, afirmam que tem um designer na empresa. Quando se observa a realidade, é o próprio

\footnotetext{
* COUTINHO, L. Design na Indústria Brasileira de Móveis. Abimóvel, São Paulo, 2001.

* CNI (Confederação Nacional da Indústria). A Importância do Design para sua Empresa. Brasília: CNI, 1998
} 
empresário, um sócio da empresa, a esposa, o sobrinho ou um profissional de outra área, normalmente antigo, com habilidade prática" (informação verbal) ${ }^{31}$.

Da mesma forma, a empresa afirmar que o design é importante parece não significar que este é incorporado adequadamente no seu processo. "Na maioria dos casos a empresa tem vergonha de falar que não conhece design ou não acha importante. Quando vamos até a empresa e vemos com nossos próprios olhos, o que ela entende por design está longe daquilo esperado por quem é da área" (informação verbal) ${ }^{32}$.

Ao longo do processo de pesquisa e no contato prático no desenvolvimento de produtos para empresas de pequeno porte no Núcleo de Design / Parqtec, desde 1999, o pesquisador percebeu que estas apresentam características singulares, diferenciando-as das grandes empresas. Assim, após muitas tentativas mal-sucedidas em aplicar diretamente conhecimentos e técnicas de projeto aprendidas na academia, as mesmas foram sendo reformuladas para se adaptar à realidade encontrada neste porte de empreendimento. Desta forma, percebeu-se que o tamanho das empresas e sua influência na manifestação prática nos processos que ocorrem intra-organizacionalmente são um conjunto de fatores que influenciavam a integração entre design e engenharia, considerando que o PDP é um processo que acontece dentro de uma organização ${ }^{33}$.

O próprio Programa Brasileiro de Design (PBD), criado em 1995 pelo Ministério de Ciência e Tecnologia para promover a inserção do design nas empresas como fator de aumento da competitividade, aponta, no seu estudo preliminar, como pontos críticos:

\footnotetext{
${ }^{31}$ Trecho retirado de entrevista para este estudo.

${ }^{32}$ Trecho retirado de entrevista para este estudo.

${ }^{33}$ O Grupo de Estudo Organizacionais das Pequenas Empresas (GEOPE), da Engenharia de Produção / Escola de Engenharia / USP São Carlos, que fornece parte do referencial teórico deste trabalho, considera que as empresas de pequeno porte se aproximam, devido às suas características, mais de grupos sociais do que de organizações, da forma como conceituadas na Teoria Administrativa.
} 
(i) a insuficiente conscientização dos segmentos empresariais quanto à importância do design;

(ii) a falta de compreensão ou conceituação distorcida sobre o design, por parte das empresas e da sociedade em geral;

(iii) a baixa integração do ensino com o parque industrial e conseqüente formação do profissional dissociada de conhecimentos tecnológicos de produção e de viabilidade econômica.

Com base na literatura e nas evidências encontradas na prática, é possível afirmar que é essencial estudar as pequenas empresas com um arcabouço teórico próprio, que as considere como um objeto de estudo de natureza diferente das grandes empresas e onde os fenômenos se manifestam de acordo com suas especificidades.

\subsubsection{Utilização do design na perspectiva de um modelo de maturidade}

O bom design é uma fonte relevante de vantagem competitiva e desempenha um papel de destaque na inovação incorporado aos produtos. Entretanto, muitas empresas de pequeno porte carecem das habilidades de um especialista em design de produto, de forma que suas atividades são na maioria das vezes desempenhadas por não-especialistas ou simplesmente ignoradas. Em alguns casos, uma empresa de consultoria em design pode ser utilizada, mas encontrar a empresa certa e gerenciar o relacionamento pode ser, na maioria das vezes, difícil. Isto é particularmente o caso do design industrial, onde muitas empresas ou compram o serviço conforme necessário ou tentam fazer por elas mesmas - este último conhecido como “Design Silencioso" (IFM, 2007). 
O papel do design industrial no processo de desenvolvimento de produtos vem se modificando desde o término da II Guerra Mundial, passando de uma intervenção superficial para um serviço estratégico e catalisador da inovação.

O IFM (2007) apresenta uma evolução histórica do papel do design industrial:

(1) Design silencioso ${ }^{34}$ : no pós-guerra, era comum que todos os aspectos do produto fossem projetados pelo time interno de engenharia, com os aspectos estéticos e ergonômicos realizado pelo membro do time mais "artístico"; estas tarefas eram vistas por muitas empresas como tarefas que poderiam ser feitas por qualquer pessoa com "bom senso";

(2) Maquiagem de Produto $^{35}$ : quando muitas empresas passaram a empregar especialistas em design, próximo a 1980, era comum que o designer industrial fosse requisitado a focar apenas nos aspectos estéticos e ergonômicos dos produtos.

(3) Inovação Orientada pelo Design ${ }^{36}$ : ao longo da década de 1990, consultorias em design industrial perceberam que poderiam oferecer outros apoios relacionados ao desenvolvimento de produtos, pois eram, na maioria das vezes, mais familiarizadas com os métodos de produção emergentes do que muitos engenheiros das equipes da empresas; também começaram a empregar uma série de novas abordagens para compreender as necessidades e desejos dos consumidores, desafiando os métodos tradicionais de pesquisa de mercado, o que colocou os designers industriais firmemente entre as funções de marketing e engenharia, como o representante dos usuários/consumidores; além disso, as empresas de design industrial começaram a oferecer serviços com foco na melhoria do processo de desenvolvimento de produtos e inovação, com atenção especial ao usuário/consumidor, fruto

\footnotetext{
${ }^{34}$ No original: Silent Design.

${ }^{35}$ No original: Superficial Styling.

${ }^{36}$ No original: Design-led Innovation
} 
do conhecimento adquirido do processo de desenvolvimento de produtos através de muitos setores industriais;

(4) Design Estratégico ${ }^{37}$ : os designers industriais ofereceram, cada vez mais, uma ampla gama de serviços estratégicos baseados nas suas habilidade centrais em compreensão do usuário, visualização e abordagem para solução de problemas; por vários motivos, designers são capazes de entender mentes através dos negócios de forma que um projeto possa satisfazer tanto as necessidade dos consumidores quanto as metas estratégicas das empresas; os prestadores de serviço de design industrial puderam oferecer, cada vez mais, expertise em todos os aspectos da inovação.

Apesar desta evolução no papel do design ao longo do século $\mathrm{XX}$, nem todas as empresas conhecem ou adotam o design industrial da mesma forma ou intensidade, embora, como visto anteriormente, aquelas que o fazem tem maior potencial de sucesso. Parece que coexistem, simultaneamente, práticas semelhantes aos diversos papéis trilhados na evolução do design, com a empresa adotando uma ou outra, de acordo com a sua compreensão.

Baseando-se nesta evolução histórica e cientes que nem todas as empresas acompanharam esta evolução, MOULTRIE, FRASER e CLARKSON (2002) propõem que as formas como as empresas entendem a expertise de design industrial e a intensidade com que integram o design industrial ao PDP e às suas atividades podem ser vistas como sua “Maturidade de Design" (ver Quadro 2.1).

\footnotetext{
${ }^{37}$ No original: Strategic Design.
} 
Quadro 2.1 - Modelo de "Maturidade de Design"

\begin{tabular}{|c|c|c|c|}
\hline Nível I & Nível II & Nível III & Nível IV \\
\hline $\begin{array}{c}\text { Design } \\
\text { Silencioso }\end{array}$ & $\begin{array}{c}\text { Maquiagem } \\
\text { de Produto }\end{array}$ & $\begin{array}{c}\text { Inovação Orientada } \\
\text { pelo Design }\end{array}$ & $\begin{array}{c}\text { Design } \\
\text { Estratégico }\end{array}$ \\
\hline $\begin{array}{c}\text { Designers são vistos } \\
\text { como caros e não- } \\
\text { práticos. Estética não é } \\
\text { percebida como } \\
\text { importante e/ou a } \\
\text { aparência dos produtos é } \\
\text { tipicamente } \\
\text { desenvolvida por } \\
\text { engenheiros ou outros } \\
\text { profissionais não- } \\
\text { especializados. }\end{array}$ & $\begin{array}{c}\text { A expertise de designers } \\
\text { profissionais é útil em } \\
\text { alguns projetos, mas } \\
\text { primordialmente } \\
\text { utilizada para “maquiar" } \\
\text { o produto. }\end{array}$ & $\begin{array}{c}\text { Designers profissionais } \\
\text { são elementos-chave } \\
\text { para a inovação e } \\
\text { sempre participam desde } \\
\text { o estágio da idéia. }\end{array}$ & $\begin{array}{c}\text { propuls } \\
\text { da inovação e } \\
\text { participam desde o } \\
\text { estágio de pré-projeto. } \\
\text { Design é uma peça } \\
\text { fundamental da cultura } \\
\text { organizacional. }\end{array}$ \\
\hline
\end{tabular}

FONTE: adaptado de MOULTRIE; FRASER e CLARKSON, 2002

Esta visão é similar à "Escada do Design"38 (NAEH \& DDC, 2003), proposta pelo Danish Design Center, onde as empresas são classificadas em 4 estágios em relação a sua visão e utilização do design industrial (ver Figura 2.8):

(i) Não-design - design não é uma questão considerada nestas empresas; não é considerada uma tarefa. O desenvolvimento do produto é realizado por funcionários que não tem nenhum treinamento específico em design. A perspectiva dos usuários finais tem pouca ou nenhuma importância no processo;

(ii) Design como maquiagem - design é sinônimo de "dar forma" ou "maquiar"; é considerado como a melhoria estética final dos produtos. Em alguns casos esta tarefa é realizada por designers, mas, na maioria das vezes, a pessoa envolvida neste estágio não tem treinamento específico em design;

(iii) Design como processo - design é um processo que acompanha o desenvolvimento de produtos a partir dos estágios mais iniciais. As soluções de design são combinadas com as tarefas e são focadas nas necessidades dos usuários finais dos produtos.

\footnotetext{
${ }^{38}$ No original: Design Ladder.
} 
Nesta abordagem multidisciplinar, os designers cooperam com técnicos de processo, materiais, marketing e outros especialistas da organização;

(iv) Design como inovação - os designers cooperam com a administração para tomar uma abordagem inovadora para todos os maiores setores que formam a base do negócio. $\mathrm{O}$ processo de design não é limitado apenas aos produtos, mas combina a visão da empresa com o seu futuro papel na cadeia de criação de valor.

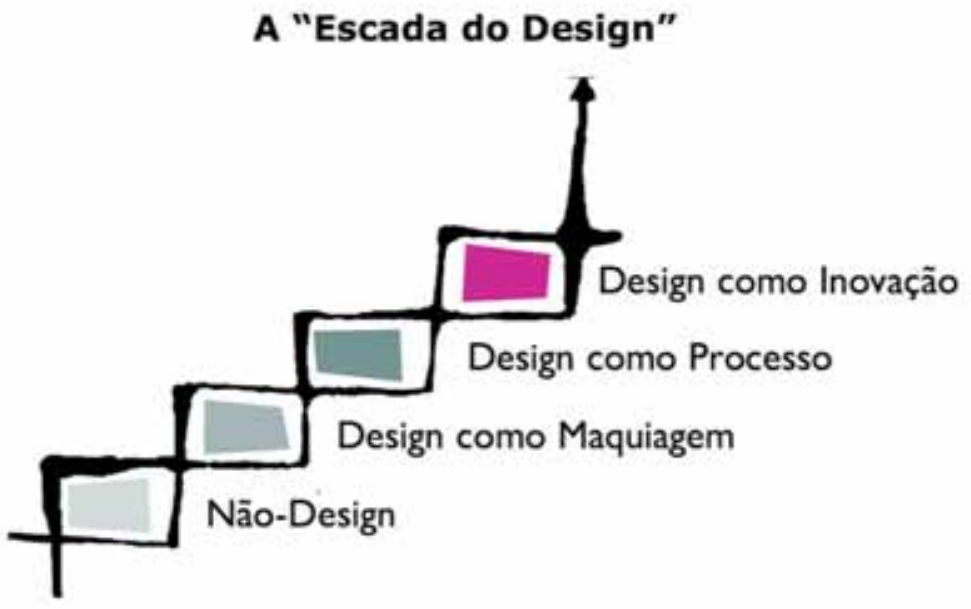

Figura 2.8 - A "Escada do Design"

FONTE: Adaptado de SWEDISH INDUSTRIAL DESIGN FOUNDATION, 2007

Este modelo de maturidade foi utilizado, em vários estudos, para desafiar a visão das empresas sobre importância percebida em relação ao design, para orientar mudança no comportamento e para embasar iniciativas governamentais de apoio, sendo amplamente utilizado na Europa.

Boa parte dos estudos apresentados na revisão bibliográfica se utilizam explicitamente de modelos de maturidade do tipo "Escada do Design" (DESIGN COUNCIL, 2004; NAEH \& DDC, 2003; CENTRE FOR DESIGN INNOVATION, 2007; GMBH, 2006) ou modelos de maturidade semelhantes, implícita ou explicitamente (HERTENSTEIN et al., 2005; GEMSER e LEENDERS, 2001; JOHANSSON, 2006; WHYTE, BESSANT, NEELY, 2005; 
KRISTENSEN et. al, 2007). Os mesmos estudos (ver exemplo nas Figuras 2.9, 2.10 e 2.11), ao mesmo tempo em que demonstram a correlação positiva entre a intensidade de utilização do design e o desempenho no mercado, também indicam que as empresas de pequeno porte apresentam maior dificuldade em inserir o design industrial em suas atividades. Embora existam variações, pode-se indicar como comum aos estudos:

(i) grande parte das empresas de pequeno porte pratica o "não-design" ou o design como "maquiagem de produto", o que indica que integrar o design ao PDP é uma dificuldade inerente às empresas de menor porte mundialmente, na atualidade;

(ii) a principal causa apontada para este fenômeno é a falta de compreensão sobre o que é design e qual a sua possível contribuição, o que leva as empresas a adotarem estas posturas (mal-informadas);

(iii) utilizar design resulta em maior competitividade;

(iv) quanto maior o degrau em que a empresa está na escada melhores são os seus resultados.

\begin{tabular}{|l|c|c|}
\hline & $\begin{array}{c}\text { Número de } \\
\text { Empresas }\end{array}$ & \% do Total \\
\hline $\begin{array}{l}\text { Degrau 4 } \\
\text { Design como Inovação }\end{array}$ & 150 & $\mathbf{1 5 \%}$ \\
\hline $\begin{array}{l}\text { Degrau 3 } \\
\text { Design como Processo }\end{array}$ & 352 & $\mathbf{3 5 \%}$ \\
\hline $\begin{array}{l}\text { Degrau 2 } \\
\text { Design como Maquiagem }\end{array}$ & 134 & $\mathbf{1 3 \%}$ \\
\hline $\begin{array}{l}\text { Degrau 1 } \\
\text { Não-design }\end{array}$ & 362 & $\mathbf{3 6 \%}$ \\
\hline Total & 998 & $100 \%$ \\
\hline
\end{tabular}

Figura 2.9 - Distribuição das empresas dinamarquesas na "Escada do Design" FONTE: Adaptado de NAEH, DDC, 2003, p.29 


\begin{tabular}{|l|c|c|c|c|c|c|c|c|c|c|}
\hline & \multicolumn{2}{|c|}{$\begin{array}{l}10-19 \\
\text { empregados }\end{array}$} & \multicolumn{2}{c|}{$\begin{array}{c}20-49 \\
\text { empregados }\end{array}$} & $\begin{array}{c}50-100 \\
\text { empregados }\end{array}$ & \multicolumn{2}{c|}{$\begin{array}{c}100+ \\
\text { empregados }\end{array}$} & \multicolumn{2}{c|}{ Total } \\
\hline & $\begin{array}{l}\text { Num. } \\
\text { Emp. }\end{array}$ & $\%$ & $\begin{array}{l}\text { Num. } \\
\text { Emp. }\end{array}$ & $\mathbf{\%}$ & $\begin{array}{l}\text { Num. } \\
\text { Emp. }\end{array}$ & $\%$ & $\begin{array}{c}\text { Num. } \\
\text { Emp. }\end{array}$ & $\%$ & $\begin{array}{c}\text { Num. } \\
\text { Emp. }\end{array}$ & $\%$ \\
\hline $\begin{array}{l}\text { Degrau 4 } \\
\text { Design } \\
\text { como } \\
\text { Inovação }\end{array}$ & 58 & $\mathbf{1 2 . 4}$ & 50 & $\mathbf{1 5 . 2}$ & 23 & $\mathbf{2 0 . 9}$ & 18 & $\mathbf{2 0 . 0}$ & 149 & $\mathbf{1 4 . 9}$ \\
\hline $\begin{array}{l}\text { Degrau 3 } \\
\text { Design } \\
\text { como } \\
\text { Processo }\end{array}$ & 156 & $\mathbf{3 3 . 4}$ & 116 & $\mathbf{3 5 . 2}$ & 38 & $\mathbf{3 4 . 5}$ & 42 & $\mathbf{4 6 . 7}$ & 352 & $\mathbf{3 5 . 3}$ \\
\hline $\begin{array}{l}\text { Degrau 2 } \\
\text { Design } \\
\text { como } \\
\text { Maquiagem }\end{array}$ & 49 & $\mathbf{1 0 . 5}$ & 54 & $\mathbf{1 6 . 4}$ & 19 & $\mathbf{1 7 . 3}$ & 12 & $\mathbf{1 3 . 3}$ & 134 & $\mathbf{1 3 . 4}$ \\
\hline $\begin{array}{l}\text { Degrau 1 } \\
\text { Não-design }\end{array}$ & 204 & $\mathbf{4 3 . 7}$ & 110 & $\mathbf{3 3 . 3}$ & 30 & $\mathbf{2 7 . 3}$ & 18 & $\mathbf{2 0 . 0}$ & 362 & $\mathbf{3 6 . 3}$ \\
\hline Total & 467 & $\mathbf{1 0 0}$ & 330 & $\mathbf{1 0 0}$ & 110 & $\mathbf{1 0 0}$ & 90 & $\mathbf{1 0 0}$ & 997 & $\mathbf{1 0 0}$ \\
\hline
\end{tabular}

Figura 2.10 - Distribuição das empresas dinamarquesas na "Escada do Design" de acordo com o porte

FONTE: Adaptado de NAEH, DDC, 2003, p.30

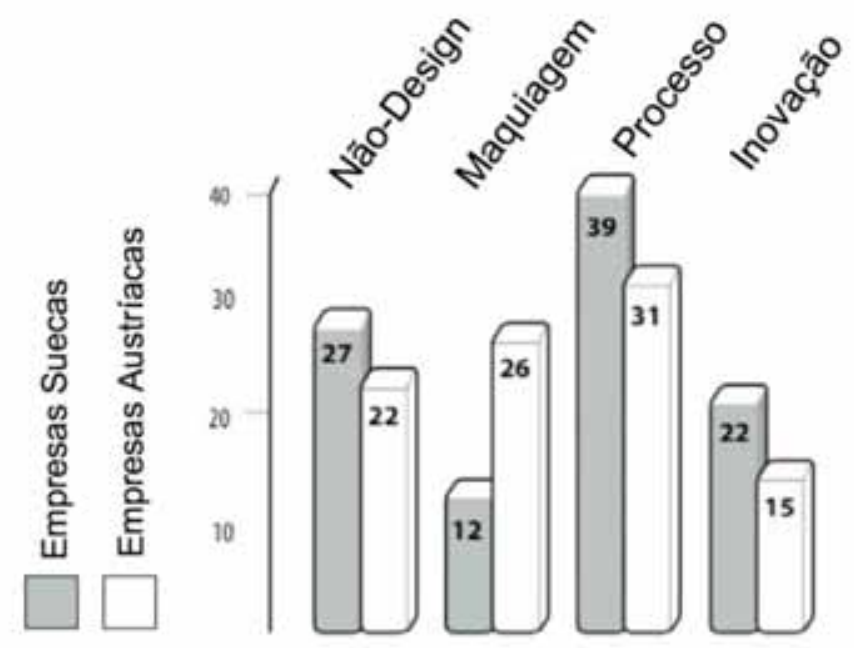

Figura 2.11 - Distribuição das empresas austríacas na "Escada do Design” em relação às empresas suecas

FONTE: Adaptado de GMBH, 2006 


\subsubsection{As empresas de pequeno porte no Brasil}

No Brasil, as EPPs representam 98\% dos estabelecimentos formalizados (mais de 5 milhões), 67\% das pessoas ocupadas no setor privado (incluindo sócios-proprietários, familiares e empregados com ou sem registro em carteira), 56\% dos empregos com carteira assinada, $62 \%$ das empresas exportadoras, $2.3 \%$ do valor das exportações e $20 \%$ do Produto Interno Bruto. Apresentam como principais características os produtos e serviços de baixo preço unitário, a predominância de vendas ao consumidor final, o atendimento de necessidades básicas da população (alimentos e bebidas; vestuário, calçados e móveis; moradia - construção e reforma), a escala de produção muito baixa (capital, insumos, materiais, mão-de-obra, etc.), a utilização de tecnologia de domínio público. Estão distribuídas, de acordo com o setor de atividade, em 56\% no comércio, 30\% em serviços e $14 \%$ na indústria. A região Sul representa $24 \%$ e a região Sudeste cerca de $51 \%$ do total das EPPs. O Estado de São Paulo concentra praticamente 31\% das EPPs do Brasil, sendo o estado com maior participação - Minas Gerais está em segundo lugar, com 11.6\% (SEBRAE, 2006a).

O Estado de São Paulo tem aproximadamente 1,5 milhão de estabelecimentos formalizados $^{39}$ (1.544.065). Deste total, 98\% são EPPs e apenas 2\% são MGEs, sendo que as primeiras geram quase $70 \%$ dos postos de trabalho. A distribuição das EPPs de acordo com o setor de atividade resulta em 53\% no comércio, $34 \%$ em serviços e $13 \%$ na indústria. Observa-se forte concentração de empresas em atividades tradicionais, com baixo grau de elaboração, com baixo volume de capital, com tecnologia de domínio público e produtos voltados para o atendimento das necessidades básicas da população, embora seja observável uma expansão para produtos relacionados à modernização da sociedade. O Estado de São

\footnotetext{
${ }^{39} \mathrm{O}$ estudo aponta que, se for considerado o setor informal e os aspirantes a empreendedor, pode-se chegar a 4.5 milhões de pessoas envolvidas na coordenação de alguma atividade empreendedora no Estado.
} 
Paulo apresenta uma base industrial com maior grau de sofisticação quando comparado à média nacional. (SEBRAE, 2006b).

Uma característica das EPPs formalmente constituídas é que o número médio de pessoas ocupadas situa-se em torno de 4 a 5 pessoas, incluindo os sócios-proprietários, familiares e empregados com ou sem registro em carteira. No setor industrial, tal qual nos outros setores, verifica-se uma grande quantidade de estabelecimentos com portes muito pequenos - média de 5 empregados com registro (RAIS, 2004* apud SEBRAE, 2006b) ou 7.26 pessoas ocupadas por empresa, sendo 1.82 sócios e familiares e 5.44 empregados próprios ou de terceiros (SEBRAE-SP, 2006* apud SEBRAE, 2006b).

É possível observar que, no Brasil, como nos outros países, as empresas de pequeno porte são a maioria e tem um papel fundamental na economia. Ainda assim, carecem de estudos modelados especificamente para seu porte. Na área de design, não foi encontrado nenhum estudo do tipo "Escada do Design", como os anteriormente apresentados.

\subsubsection{Problemas e limitações inerentes ao PDP}

Existe uma ampla gama de estudos sobre os problemas do processo de desenvolvimento de produtos. Acredita-se que é possível considerar que o próprio processo de desenvolvimento de produtos, enquanto objeto de estudo, é na realidade uma abstração da realidade para possibilitar a melhoria do próprio processo. Neste sentido, é um conjunto de "Boas Práticas" para evitar ou solucionar problemas que acontecem inerentemente nesta atividade altamente complexa em vários sentidos. Considera-se que não é necessário neste

\footnotetext{
* RAIS. Relação Annual de Informações Sociais (RAIS). Brasília (DF), Ministério do Trabalho e Emprego. CDROM.

* SEBRAE-SP. "Indicadores Sebrae-SP: pesquisa de conjuntura". Pesquisa realizada mensalmente com uma amostra planejada de 2.700 empresas de micro e pequeno porte, no Estado de São Paulo.
} 
trabalho fazer um grande levantamento sobre o assunto, limitando-se a citar os aspectos principais e mais relacionados com o tema em questão.

Os profissionais que participam do PDP são especialistas, influenciando a qualidade do processo. Sobre este aspecto, ROZENFELD e SILVA (1998) listam como problemas e limitações ao desenvolvimento de produtos: dificuldade de projetar com simplicidade, falta de atenção para a qualidade do produto, tempo excessivo de desenvolvimento, falta de integração entre as fases de projeto e de produção, falta de foco no cliente, pouco envolvimento dos fornecedores no desenvolvimento de produtos e erros detectados e corrigidos somente em fases finais do desenvolvimento. Uma das principais causas destas limitações é a contribuição das pessoas somente como especialistas, em uma determinada fase do desenvolvimento, em alguma tarefa pontual e isoladas.

\begin{abstract}
"Outra característica diferencial e importante do PDP é o emprego de pessoas com formação e visões muito distintas, que fazem uso de diferentes áreas do conhecimento e, portanto, geralmente mais afeitas a dar importância a um conjunto específico de fatores: aqueles mais próximos da sua área de formação. São engenheiros, físicos, designers, economistas, administradores e até mesmo pessoas com formação em recursos humanos (...) Assim, um grande desafio é obter e transmitir uma visão integrada e comum que considere os aspectos destas diferentes disciplinas." (AMARAL, 2002, p.08).
\end{abstract}

Os problemas do PDP em integrar eficientemente profissionais diferentes são relacionados não apenas à integração do design industrial no processo, mas a qualquer profissional. Desta forma, as mesmas constatações e técnicas para maximizar a integração dos profissionais no PDP, se aplicam ao design industrial.

$\mathrm{Na}$ realidade, este estudo poderá ser visto, ao final, como relacionado com a integração desta área de conhecimento específica, o design industrial, à engenharia no PDP, da mesma forma como existem estudos específicos sobre a integração de profissionais de marketing, psicologia e outros neste processo. 


\subsubsection{A lacuna cultural entre engenheiros e designers}

MOULTRIE, CLARKSON e PROBERT (2007) argumentam que há evidências teóricas e anedóticas ${ }^{40}$ sobre a contribuição crítica do design para o sucesso do negócio, mas também há evidências que as pequenas empresas falham em obter a vantagem destes benefícios. Indicam, enquanto realizam uma ampla revisão bibliográfica sobre o assunto, o analfabetismo $^{41}$ em design como uma característica das empresas orientadas para dentro ${ }^{42}$, com informação de mercado obtida apenas internamente e uma ênfase demasiada em engenharia em detrimento de facilidade de uso e apelo visual. Como resultado, o design é marginalizado. Uma consequência é a execução de atividades de design por pessoas que não tem treinamento ou aptidão em design. Uma possível explicação para esta marginalização é a resistência de administradores seniores para com o design industrial, baseado em preconceitos infundados e comportamentos sedimentados na tradição.

Estas observações parecem ser relacionadas a uma "lacuna cultural" existente entre designers e engenheiros, como apontam os estudos abaixo.

Segundo o IfM (IFM, 2007), para produzir design coerente, deve existir uma integração entre diferentes disciplinas de projeto, incluindo planejamento de produto, design industrial e engenharia. Entretanto, isto pode ser difícil, pois é normalmente percebido que existe uma lacuna cultural $^{43}$ entre engenheiros e designers industriais. Adicionalmente, pequenas empresas de engenharia podem nem mesmo incluir um especialista em design industrial. Nestes casos, é importante ter um processo robusto para design e desenvolvimento de produto, para garantir que importantes questões não sejam ignoradas.

\footnotetext{
${ }^{40}$ Oriundas de exemplos de sucesso, estudos de caso isolados, experiência e relatos etc.

${ }^{41}$ No original: illiteracy.

${ }^{42}$ No original: inward-looking.

${ }^{43}$ No original: cultural gap.
} 
DAVIES (1977* apud MOODY, 1980), também sugere a existência de uma lacuna cultural, para explicar as disfunções e até mesmo o preconceito existente entre engenheiros e designers industriais, sem entrar em maiores detalhes sobre o que constituiria esta lacuna.

Evidências encontradas na bibliografia e os exemplos na prática da profissão sugerem que a importância dos valores intangíveis e qual o papel do design industrial no PDP para projetar estes valores não é tão claro para profissionais envolvidos no PDP ligados às áreas mais próximas das ciências exatas e tecnológicas. Para estes, a noção parece ser que o aparato técnico desenvolvido será aceito prontamente apenas pelas suas características técnicas, uma vez que resolvem um problema técnico de forma inovadora e eficiente. Além disso, o design industrial é considerado apenas como intervenção estética, e, portanto, pouco profunda e descartável.

O resultado pode ser a negligência quanto ao projeto adequado dos atributos que o produto deve possuir em relação interface com os seres humanos no PDP. Sobre este aspecto, MOODY (1980, p.332, grifo nosso) comenta as implicações:

\footnotetext{
"Um produto que foi projetado apenas em relação às suas funções técnicas é deficiente de diversas maneiras. $O$ produto não foi projetado para ser uma contínua extensão do usuário e, portanto, é psicologicamente incompatível. Como resultado, o consumidor potencial pode não gostar do produto por razões que ele é incapaz de definir, mas que apesar disso causa relutância em comprar o produto. $\mathrm{O}$ produto pode não levar em conta todas as necessidades técnicas relacionadas ao usuário; estas terão que ser atendidas por muitos produtos separados. O usuário pode ter que se adaptar ergonomicamente ao produto. Isto pode causar desconforto, stress ou fadiga no usuário, levando a tarefa a ser menos prazerosa. Pode diminuir a eficiência com que o usuário realiza a tarefa. [...] A manutenção do produto pode ser complicada e, consequentemente, negligenciada pelo usuário. Todos estes fatores podem reduzir o sucesso comercial do produto e é neste ponto onde os objetivos da inovação tecnológica e do design industrial se fundem. Ambos têm por objetivo atingir sucesso no mercado; o primeiro através do oferecimento aos usuários potenciais uma nova facilidade técnica a um preço acessível, o último através da disponibilização desta facilidade técnica aos usuários numa forma que os atraia."
}

\footnotetext{
* DAVIES, D. Demolishing the caricature of the two design cultures. Design, n.o 347, November 1977, p.19
} 
Parte do problema pode se originar na constatação que a engenharia e o design industrial, apesar de se sobreporem em diversos aspectos, carregam diferenças em diversos níveis que produzem uma tensão que se traduz numa complexa rede de forças, que varia da ignorância total dos profissionais de uma área pela outra, até o preconceito velado ou explícito. A tensão que carrega esta relação é semelhante à observada entre arquitetura e engenharia civil.

Sobre este aspecto, MOODY (1980, p.329) coloca que o design industrial é:

\begin{abstract}
"É uma tentativa consciente para trazer ordem visual e formal para a engenharia de equipamentos onde a tecnologia por si só não oferece estas qualidades. É também uma tentativa consciente de relacionar a engenharia de equipamentos as dimensões, respostas instintivas e necessidades emocionais das pessoas, onde estes são requisitos relevantes. A arquitetura oferece uma analogia apropriada: o design industrial está para a engenharia assim como a arquitetura está para a construção civil. Máquinas e equipamentos podem ser construídos sem a ajuda de designers industriais assim como construções podem ser construídas sem a ajuda de arquitetos. Entretanto, pode ser argumentado que para ser totalmente satisfatórios como objetos feitos pelo homem, máquinas e construções necessitam de intervenção estética dos designers industriais e dos arquitetos, respectivamente."
\end{abstract}

Estes aspectos formam, provavelmente, a base para a investigação da citada lacuna cultural. Porém, os artigos avaliados não forneceram explicitamente maiores detalhes em profundidade, que possam lançar uma luz sobre esta lacuna cultural.

A literatura brasileira, embora não utilize o termo lacuna cultural, indica que a falta de compreensão sobre o que é design, qual a sua contribuição e qual o seu papel é disseminada. BAARS (2002, p.22), por exemplo, comenta que um dos motivos pelo qual os gestores não priorizam o design é a deficiência na compreensão do seu real significado. A despeito disso, normalmente os estudos não se aprofundam na investigação das bases em que este fenômeno ocorre.

FISHER e URY (1991), pesquisadores do Harvard Negociation Project, sugerem que as diferenças podem ser transpostas, em parte, através do reconhecimento das mesmas, isto é, 
uma técnica valiosa para chegar ao consenso é reconhecer as diferenças (ou posições) entre membros de um grupo e então focar em interesses compartilhados.

Assim sendo, busca-se articular uma revisão bibliográfica de forma a delimitar melhor os contornos desta lacuna, sua caracterização e possíveis influências no PDP, pois existem evidências teóricas e práticas que indicam que esta lacuna cultural tem papel preponderante nas disfunções da integração entre design e engenharia.

\title{
2.2.3.1.Delineando a lacuna cultural
}

\begin{abstract}
"[O engenheiro esqueceu o usuário?] Com apenas uma palavra para responder a esta questão, 'sim'; com mais palavras, 'na maioria das vezes'. Para qualificar esta afirmação, vou começar com um exemplo pessoal. Tendo obtido um grau de mestre em engenharia mecânica, meu primeiro trabalho foi simplesmente 'desenvolver uma escada de cozinha'. A primeira coisa que fiz foi avaliar produtos concorrentes para entender o que fazia eles funcionarem. Tendo avaliado diversas soluções técnicas, por palpite selecionei o conceito que pensei ser o melhor. Desenhos foram feitos e um protótipo foi construído, testado, modificado, testado e mais, até encontrar uma solução satisfatória. Durante todo o processo minha única preocupação foi com a tecnologia. Nunca me ocorreu contatar possíveis usuários como donas-de-casa - e perguntar sobre seus problemas de carregar pesos. Tendo terminado o projeto da escada de cozinha, minha próxima tarefa foi desenvolver um refrigerador comercial para uma empresa de laticínios que encomendou 150 unidades para suas lojas de leite. O trabalho consistiu em selecionar o mais econômico compressor e determinar as formas e dimensões do gabinete, portas, etc. O maior desafio foi ter pouco desperdício de materiais e projetar a unidade de forma que pudesse ser produzida ao menor custo possível. Novamente, a tecnologia foi o foco. Nenhuma atenção foi dada a visitar as lojas de leite e observar as vendedoras em ação ou questioná-las sobre seus problemas. Mais tarde, eu ganhei experiência no projeto de produtos industriais e produtos militares. Minha abordagem foi sempre a mesma, a do típico engenheiro. Tendo encontrado um princípio físico que ofereceria um conceito útil para a solução do problema assumido, minha energia era concentrada em selecionar os materiais adequados e encontrar formas e dimensões tanto da configuração total como quanto das várias peças. Durante todo o processo o usuário foi negligenciado, se lembrado de qualquer forma." (HOLT, 1989, p.163, grifo nosso).
\end{abstract}

O depoimento acima ilustra uma situação típica, mais comum do que seria desejada,

introduzindo o assunto sobre a lacuna cultural entre designers e engenheiros. Obviamente, somente expõe a superfície do fenômeno, sendo, na realidade, um dos efeitos mais evidentes 
desta lacuna. Encontrar as possíveis causas, isto é, os componentes que constituem esta lacuna cultural, é o esforço realizado nas próximas páginas.

A revisão bibliográfica não conduziu a um estudo especificamente sobre o tema, que descrevesse a lacuna cultural. Concentrou-se assim na observação e articulação de uma miríade de publicações, compilando aspectos que poderiam compor um delineamento preliminar. Acredita-se que boa parte da lacuna é oriunda das diversas diferenças existentes entre as duas áreas de conhecimento e prática profissional. Portanto, os esforços foram orientados para identificar quais são estas diferenças e coletar evidências que sustentassem sua atribuição como componente dos fatores que influenciam a integração entre design e engenharia, sendo este o fio condutor do processo investigativo.

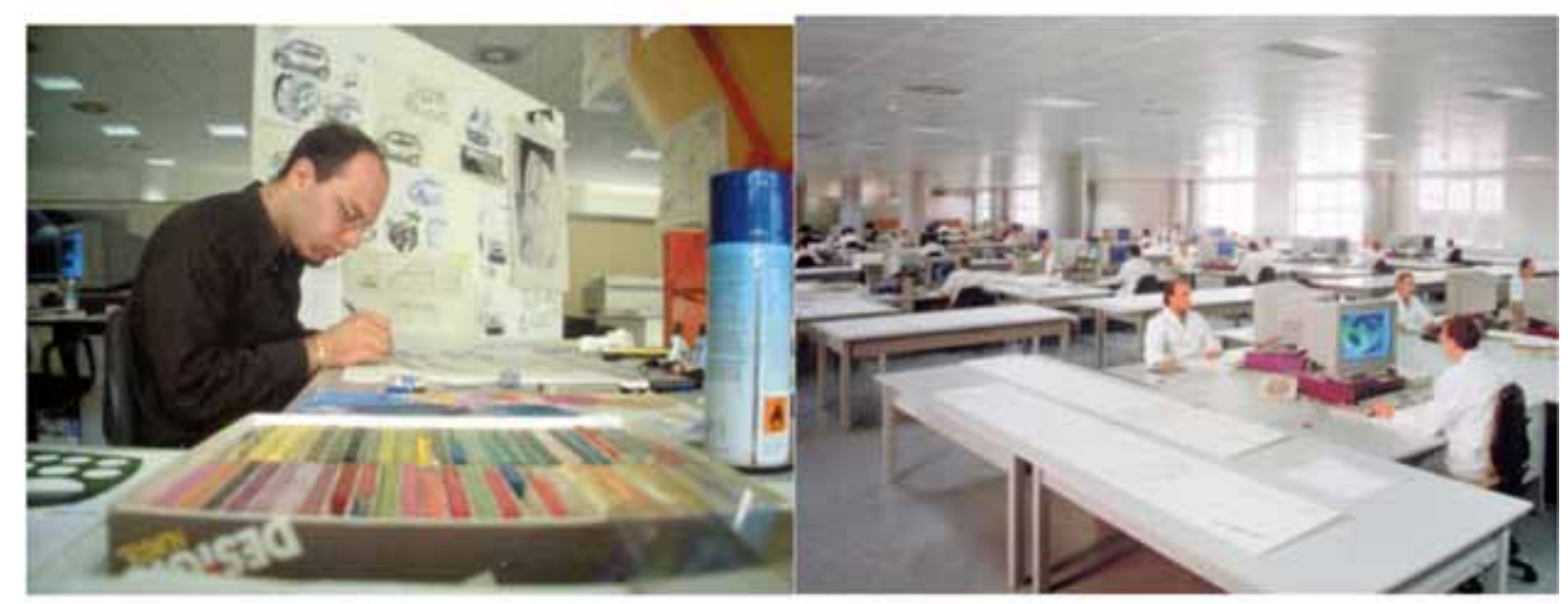

Figura 2.12 - Duas culturas: departamento de design (à direita) e departamento de engenharia de indústria automobilística

\subsubsection{Diferenças na natureza dos problemas e objetivos de projeto}

A engenharia se depara com problemas iniciais mais definidos e detalhados do que o design industrial, até porque é possível, dada a natureza dos problemas que tratam, estabelecer indicadores quantitativos e modelagens matemáticas precocemente. Os problemas de design tendem a ser mal-definidos, pouco conhecidos e com forte orientação subjetiva, conduzindo 
ao uso de técnicas mais abertas e especulativas no detalhamento da solução ao longo do projeto.

"Arquitetos e designers industriais também tendem a ver seus problemas de projeto como inerentemente mal-definidos, enquanto os problemas dos engenheiros são mais comumente bem-definidos ${ }^{44}$." (ROOZENBURG E CROSS, 1991, p. 218)

Os objetivos finais do projeto também são diferentes. A engenharia tem por objetivo último conceber um artefato que realize uma tarefa "técnica" de forma eficiente e eficaz, enquanto o design industrial tem por objetivo último adequar este artefato ao ser humano que irá utilizá-lo.

KINDLEIN (2006) coloca que o engenheiro concebe, sobretudo, um produto técnico; está mais próximo das características físicas e técnicas do produto, sem focar o lado perceptivo por parte do usuário. O objeto real do seu trabalho permanece no desempenho técnico do produto. Normalmente, este especialista fornece uma resposta na qual a visão funcional e técnica do produto é prioritária, sem necessariamente levar em conta as possibilidades de modificações ou de melhorias ligadas ao uso ou o ambiente. Por outro lado, o conhecimento do designer, se orienta, sobretudo, aos usos, às apropriações, os modos de consumo, inscrevendo-se plenamente na perspectiva do usuário. $\mathrm{O}$ designer pesquisa primeiro o modo de vida do consumidor, os seus hábitos, o seu comportamento, a sua história. O desafio deste profissional é apreender perfeitamente o funcionamento do consumidor a fim de fornecer-lhe o produto ideal. O designer estuda o funcionamento do consumidor através da percepção que este último pode ter do produto, igualmente um ponto de vista fisiológico (identificação dos órgãos humanos receptores ligados à percepção); psicológico (identificação das relações estreitas entre percepção, os sentimentos e comportamento do consumidor).

\footnotetext{
${ }^{44}$ No original: ill-defined e well-defined, respectivamente.
} 


\subsubsection{Diferenças nas metodologias e técnicas de projeto}

Com problemas de projeto e objetivos diversos, não é de se estranhar que as metodologias de projeto, embora ambas normalmente tenham uma abordagem de afunilamento na tomada de decisões, tenham uma dinâmica diferente.

ROZENBURG E CROSS (1991) analisam que, após começar a partir de origens comuns, apareceram diferenças significativas entre os tipos de modelos para projeto de engenharia e projeto de arquitetura e/ou design industrial. A maior diferença é a natureza aparentemente linear, seqüencial dos modelos de engenharia versus a natureza espiral, cíclica dos outros. Modelos de processo de projeto de engenharia tendem a enfatizar as seqüências de estágios através do qual o projeto é esperado progredir (ex. estágios conceitual encorpamento - detalhamento), enquanto os modelos de projeto da arquitetura/design industrial enfatizam o ciclo de processos cognitivos que o designer é requisitado a executar (ex. pensamento produtivo - dedutivo - indutivo). Desta forma, os modelos da engenharia são mais prescritivos, enfatizando a seqüência de estágios que são esperados a ocorrer durante o desenvolvimento do projeto, e os modelos do design industrial são mais descritivos, enfatizando os processos de pensamento que podem - ou devem - ser empregados pelo designer ao longo do desenvolvimento.

Para ROOZENBURG E CROSS (1991, p.218)

"há provavelmente algumas razões compreensíveis para estas diferenças entre os
modelos. Em particular, os domínios do conhecimento para as profissões são
diferentes. Arquitetos e designers industriais carecem, para seus problemas
essenciais, do equivalente às ciências da engenharia que são disponíveis aos
engenheiros projetistas; os primeiros então têm que se basear muito mais em
procedimentos de tentativa e erro."

Obviamente, existem disciplinas que embasam o processo de desenvolvimento de produtos a partir da ótica do design industrial, mas sua base e seus métodos principais são 
oriundos ou tendem a se aproximar das ciências humanas - como a sociologia, psicologia, estética aplicada, estética do valor, por exemplo - divergindo dos métodos comumente aplicados nas engenharias, mais quantitativos e matemáticos. Natural que seja assim, uma vez que, em última análise, o design industrial estuda o próprio homem em suas dimensões físicas, psicológicas, econômicas e sociais, na tentativa de melhor desenvolver a interface deste para com os produtos.

Designers e engenheiros carregam grandes diferenças na sua formação acadêmica e prática no processo de desenvolvimento de produtos, e, como na sua base são de natureza diversa, sua integração durante o processo pode ser delicada por uma questão simples de comunicação. Ambos os conhecimentos e vertentes de abordagens são importantes ao processo, se o objetivo for configurar produtos preparados para a concorrência no mercado atual. Dependendo do setor, do tipo de produto, das informações necessárias obter para o projeto, dos objetivos e até mesmo da fase de desenvolvimento, uma abordagem pode ser mais eficaz e eficiente que a outra.

Os tipos de pesquisa realizada diferem, bem como seus métodos, considerando que os dois profissionais privilegiam e buscam obter eficiência no projeto de diferentes aspectos do produto, como foi visto. De uma forma geral, os designers industriais se valem de métodos mais ligadas às ciências humanas e os engenheiros, obviamente, das ciências exatas. Nesta consideração já reside um grande abismo metodológico.

A pesquisa de necessidades psico-perceptivas, cognitivas e sociais, por exemplo, principalmente aquelas não explícitas, têm importância essencial para os produtos da atualidade, sendo que grande parte do processo de compra e satisfação do consumidor será determinado por estes fatores intangíveis. A investigação deste tipo de necessidades e a sua transformação em requisitos para produtos é tarefa para os designers industriais, considerando 
que os métodos de investigação das necessidades e transformação em requisitos de projetos sob a ótica da engenharia normalmente não captam este tipo de fenômeno, pois se preocupam com necessidades racionais.

HOLT (1989) comenta que a maioria dos métodos de pesquisa de necessidades, do ponto de vista da engenharia, se preocupa com necessidades racionais. Outros métodos, porém, podem também revelar necessidades não racionais e emocionais, relacionadas com status, novidade, forma, estilo, cor e outras características de natureza estética. Estas necessidades relacionam-se com a maneira como o usuários percebe o produto e apelar para elas, que em alto grau são um fenômeno subjetivo, é típico de artigos de moda e artigos de luxo. A mesma situação prevalece para produtos de consumo duráveis que apresentam pequenas diferenças nas características tecnológicas. Também para muitos produtos industriais as necessidades emocionais podem ser importantes.

Sobre este aspecto TOVEY (1989, p.35), analisando o processo de desenvolvimento de automóveis, comenta que

\footnotetext{
“planejadores de produtos trabalharão com especificações, e engenheiros de 'corpo' estarão trabalhando com modelos computacionais. Ambos estarão lidando principalmente com processos de avaliação analíticos. Estilistas [designers industriais] estarão trabalhando com sketches de projeto e lidando principalmente com processos holístico-sintéticos. [...] De uma forma geral, os modelos, procedimentos e operações de sistemas de CAD para engenharia não são adequados aos processos e técnicas aplicadas nos estágios iniciais do processo de projeto (onde os designers industriais têm maior peso) [...]."
}

Para TOVEY (1989, p.35), o processo de projeto completo envolve combinações de processos [cerebrais] analítico-avaliativos e holístico-sintéticos, e, durante estes processos o projeto é modificado numa variedade de formas: especificações em palavras e números, sketches, como desenhos em escala, modelos computacionais ou representações tridimensionais físicas. Designers industriais estarão trabalhando com design sketches e 
lidando, principalmente, com processos holístico-sintéticos (ver Figura 2.13). Seu pensamento

de projeto poderia ser caracterizado como tendo os seguintes aspectos:

- Envolve processos do hemisfério direito do cérebro;

- É não-verbal/manipuloespacial;

- É holístico e sintético;

- Começa com a proposta de uma solução global e depois trabalha nos detalhes. É chamado "percepção desfocada" (uma importante característica da criatividade visual): um modelo mental do design que contém ambiguidade suficiente para permitir o desenvolvimento de um novo conceito;

- Envolve geração de imagens - a criação mental de imagens como idéias vagas ou fotogramas mentais, que são externalizados em esboços informais;

- Necessita de "ideação gráfica”, embora, para facilitar o pensamento de projeto, os desenhos possam ser privados e incompreensíveis para outros;

- Conhecimento não-verbal, difícil de ser comunicado em palavras, empregando um tipo de conhecimento tácito que é difícil de transmitir, mas que os designers reconhecem entre si;

- Lida com julgamentos da aparência visual, empregando uma sofisticada e controlada linguagem visual;

- É visual e concreta; designers não gostam de representações abstratas, matemáticas ou simbólicas;

- $\quad$ Lida com a integração de relações visuais de forma holística.

(A)

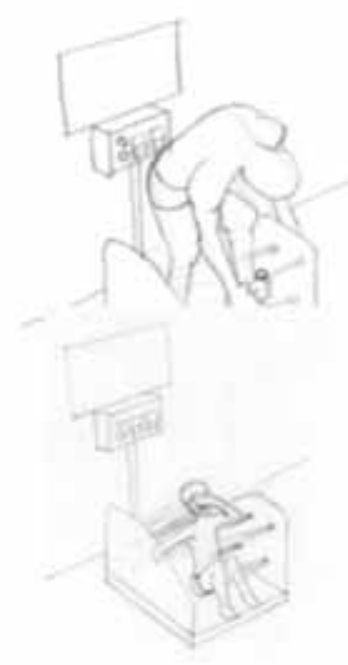

(B)

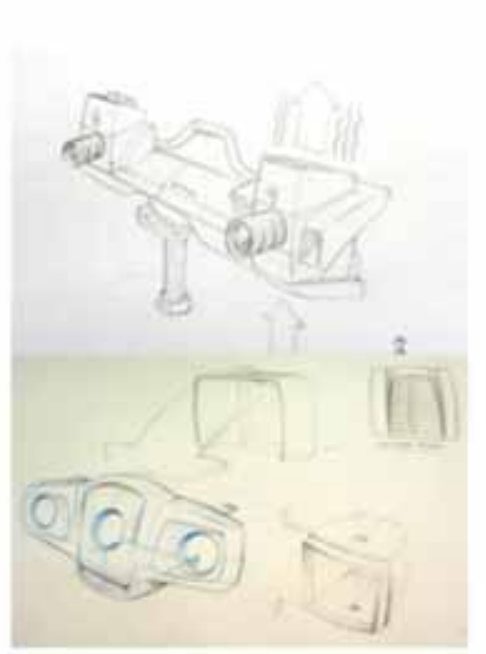

(C)

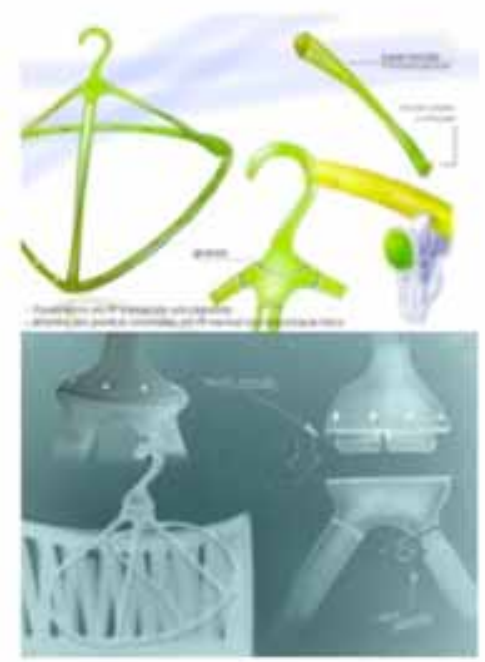

Figura 2.13 - Exemplos de sketches de projeto reais que expressam "pensamento visual" $\mathrm{e}$ processos cerebrais holístico-sintéticos

(A) Sketches para projeto de dispositivo para lavagem - designer industrial Davi Rosa, 2006; (B) Sketches para projeto de scanner 3D - designer industrial André Mozeto, 2007; (C) Sketches para projeto de varal para uso doméstico - designer industrial Jean Victor Colhado, 2007 
Estas características estão enraizadas em processos cerebrais de resolução de problemas diferentes entre designers e engenheiros, como será visto mais à frente. Na prática, parece ser uma fonte de conflitos de comunicação entre os dois tipos de profissionais. $\mathrm{O}$ designer tem dificuldades em lidar com modelos matemáticos e linguagem verbal (ver Figura 2.14) e o engenheiro tem dificuldade em compreender o tipo de visualização holística, mas não detalhada inicialmente dos designers (ver Figura 2.15).

Estes diferenças vão se manifestar de diversas formas durante o processo de desenvolvimento de produtos, como descreve KINDLEIN (2006, p.6):

(i) Engenharia

\begin{abstract}
"Durante as diferentes fases do processo de concepção, o engenheiro planeja o futuro produto utilizando convenções e instrumentos adquiridos em sua formação inicial e contínua (desenhos técnicos, desenhos globais, planos detalhados, etc.). Neste aspecto, o produto primeiro é representado a partir das capacidades oferecidas pelas modelagens científicas que permitem dar configuração e dimensionamento aos seus principais elementos, em relação à sua capacidade física de ser materializado. Inspirando-se junto a metodologias procedentes da análise do valor, nas fases da concepção, o engenheiro trabalha a partir de um processo técnico e econômico que caracteriza o futuro produto. Efetua então numerosos cálculos a fim de dimensionálo. Este dimensionamento está ligado às características pedidas pelo cliente. Os cálculos são realizados através de diferentes "softwares" de simulação e estes são fundados sobre diferentes abordagens ou teorias científicas e recorridos a uma representação do produto através de parâmetros numéricos. A competência dos engenheiros é aqui fortemente ligada ao seu conhecimento em cálculos e a "destreza" de saber utilizá-los." - ver Figura 2.14.
\end{abstract}

(ii) Design industrial

"[...] Possui conhecimentos ligados à "medida" da percepção (instrumentos psicométricos, perfis sensoriais) e a relação consumidor/produto (tendências, histórico dos produtos, famílias de produtos, etc.). A formação deve conduzir e igualmente familiarizar o Designer com os materiais e, em especial, com o campo amplo de materiais disponíveis (cerâmicos, polímeros, metais, etc.). Finalmente o Designer, focaliza seu interesse no consumidor em termos de modos de vida ou mesmo de hábitos. De certa maneira sua proximidade com o consumidor o afasta das características estruturais e cálculos relativos ao produto.” - ver Figura 2.15 


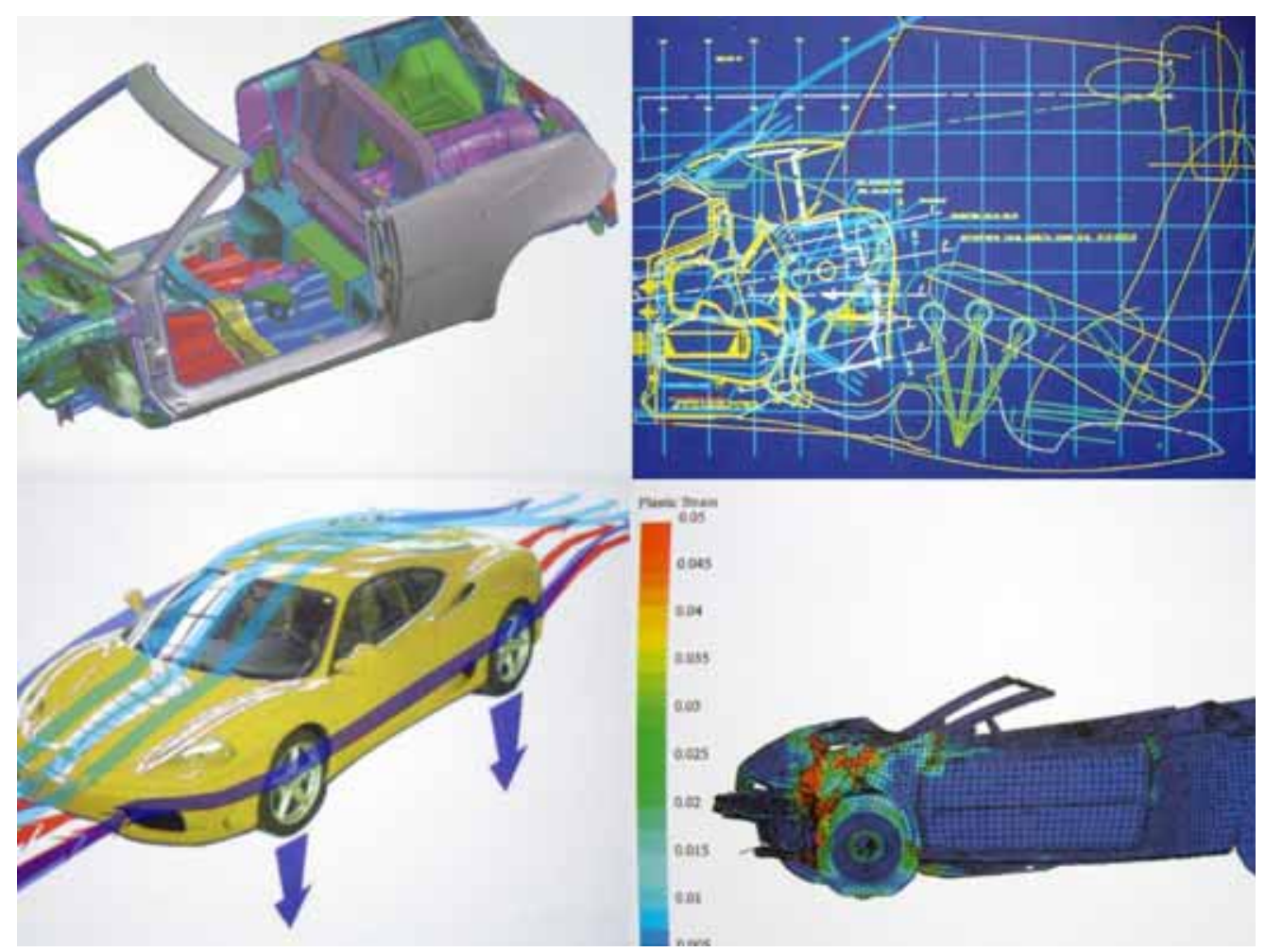

Figura 2.14 - Exemplos técnicas de projeto típicas da engenharia - modelagem matemática

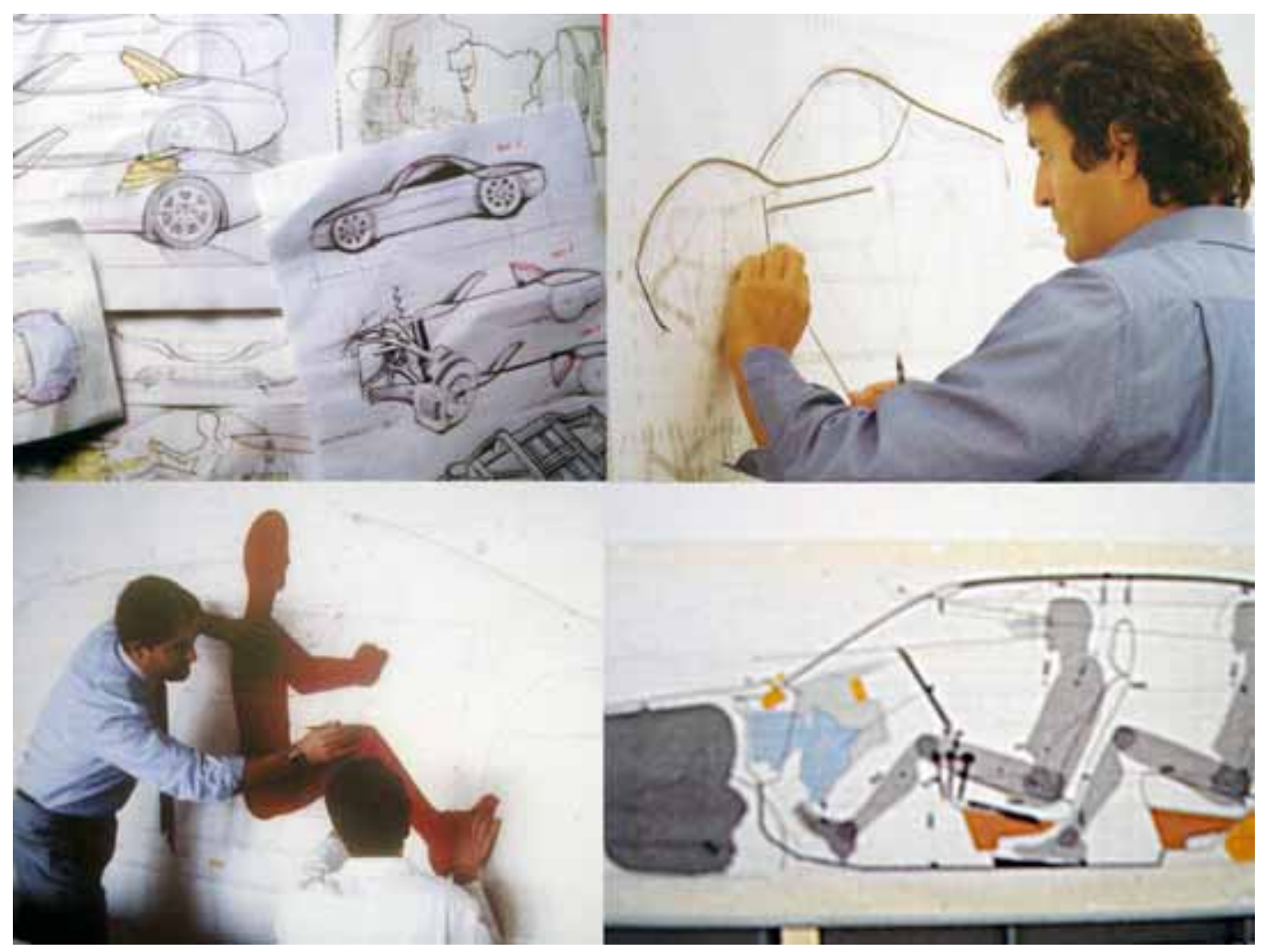

Figura 2.15 - Exemplos de técnicas de projeto típicas do design industrial - linguagem holísticosintética 
TOVEY (1997) ressalta a forma de projetar dos designers industriais na indústria automobilística, onde é mais clara a divisão de responsabilidades e os limites de cada área do conhecimento.

\begin{abstract}
"Nos processos de projeto de estilo [design industrial] houve muito menos uso de computação do que na engenharia. Há características importantes do processo de estilo que torna difícil analisá-lo e dar uma forma externa aos seus processos detalhados. Isto porque é intuitivo e holístico, com uma forte cultura não-verbal. É também individual e existem, às vezes, diferenças bem definidas de abordagem e técnica de um estilista [design industrial] para outro." (p.10) [...] "De forma a entender e examinar objetivamente o design industrial foi necessário colocá-lo em seu contexto histórico e educacional. Foi definido de forma a se distinguir de outros tipos de design, tanto de forma geral, quanto em seu processo particular de criar produtos manufaturados. Designers industriais empregam técnicas visuais, criativas e intuitivas no fazer de sua contribuição especial para o processo de projeto. Isto pode ser visto mais claramente no caso particular da indústria automobilística. É também possível identificar a partir do design automotivo o modelo operacional e as saídas requeridas que o gerenciamento [em relação à integração entre as áreas] exige." (p.29)
\end{abstract}

\subsubsection{Diferenças nos critérios de aprovação e indicadores de sucesso}

Em consequência das diferenças na natureza, nos objetivos, nas metodologias e técnicas de projeto, os critérios para se definir se o sucesso foi obtido também divergem.

\begin{abstract}
"O objetivo da atividade projetual [do design industrial] não é a produção [...] de know-how, mas a articulação da interface entre usuário e artefato. A linguagem do design não é a linguagem das asserções, nem a linguagem das instruções, mas sim a linguagem dos juízos (assessments). Estes juízos referem-se às características prático-funcionais e estético-formais. A prática standard do design é a criação de variedade e a posterior redução de variedade para criar coerência nos campos de uso, aparência, ambiente e estilo de vida. O critério de sucesso do design pode ser estabelecido com uma simples frase, vale dizer, a declaração do cliente quando ele diz: eu estou contente." (BONSIEPE, 1997, p.37)
\end{abstract}

Este aspecto provavelmente ocasiona vários dos problemas na integração dos profissionais, pois, se para um engenheiro o sucesso foi atingido quando um produto foi produzido de maneira econômica, eficiente, com qualidade adequada e cumpre bem sua função técnica, para o design industrial o produto só pode ser considerado de sucesso se foi aceito pelos consumidores - física, psicológica e socialmente (ver Quadro 2.2). 
"A condition of satisfaction no design não é a verificação de uma verdade nem tampouco a verificação empírica de uma viabilidade técnico-física, mas a correspondência entre expectativas (necessidades) de um cliente/usuário e a oferta em forma de um produto ou serviço. Ele [o cliente] é a instância máxima que pode expressar o juízo sobre a qualidade do produto ou serviço." (BONSIEPE, 1997, p.37)

Quadro 2.2 - Diferenças entre ciência, tecnologia e design

\begin{tabular}{|l|c|c|c|}
\cline { 2 - 4 } \multicolumn{1}{c|}{} & Ciência & Tecnologia & Design \\
\hline $\begin{array}{l}\text { Objetivos da } \\
\text { inovação }\end{array}$ & Inovação cognitiva & Inovação operativa & $\begin{array}{c}\text { Inovação } \\
\text { sociocultural }\end{array}$ \\
\hline Discurso dominante & Afirmações & Instruções & Juízos \\
\hline Práticas padrão & $\begin{array}{c}\text { Produção de } \\
\text { evidências }\end{array}$ & Tentativa e Erro & $\begin{array}{c}\text { Produção de } \\
\text { coerência }\end{array}$ \\
\hline Contexto social & Instituto & Empresa & Mercado \\
\hline Critérios de sucesso & OK das autoridades & Factibilidade técnica & Satisfação do cliente \\
\hline
\end{tabular}

FONTE: Adaptado de BONSIEPE, 1997, p.35

\subsubsection{Diferenças psico-fisiológicas e cognitivas}

É interessante notar que vários estudos apontam para diferenças mais profundas, enraizadas nos processos de pensamento "preferidos" pelo cérebro de cada indivíduo, em relação, por exemplo, ao lado do cérebro mais utilizado para a solução dos problemas.

KINDLEIN (2006) afirma que por hipótese, a lógica do pensamento do engenheiro e do designer é notoriamente diferente (até mesmo invertida); a comunicação entre estes dois atores na concepção do produto é frequentemente difícil (ver Figura 2.16).

TOVEY (1984, p.220) informa que uma ampla gama de experimentos indicou que modos de processamento de informação diferentes embasam estas especializações do cérebro. De uma forma geral, eles são: hemisfério esquerdo - verbal, analítico, simbólico, abstrato, lógico, linear, digital e temporal; hemisfério direito - não-verbal, sintético, concreto, analógico, intuitivo, holístico, especial, atemporal e difuso.

“[...] Design de apresentação [uma subárea do design industrial] depende de pensamento visual e esta é uma das áreas onde o hemisfério direito é mais dominante. Ao contrário de outros aspectos do projeto, a avaliação da qualidade da aparência de um produto também pareceria estar fora do escopo dos procedimentos lógico-analíticos [do hemisfério esquerdo]. Nesta instância, o lado direito do cérebro 
deve não apenas produzir as propostas de projeto, mas também avaliá-las." (TOVEY, 1984, p.225).

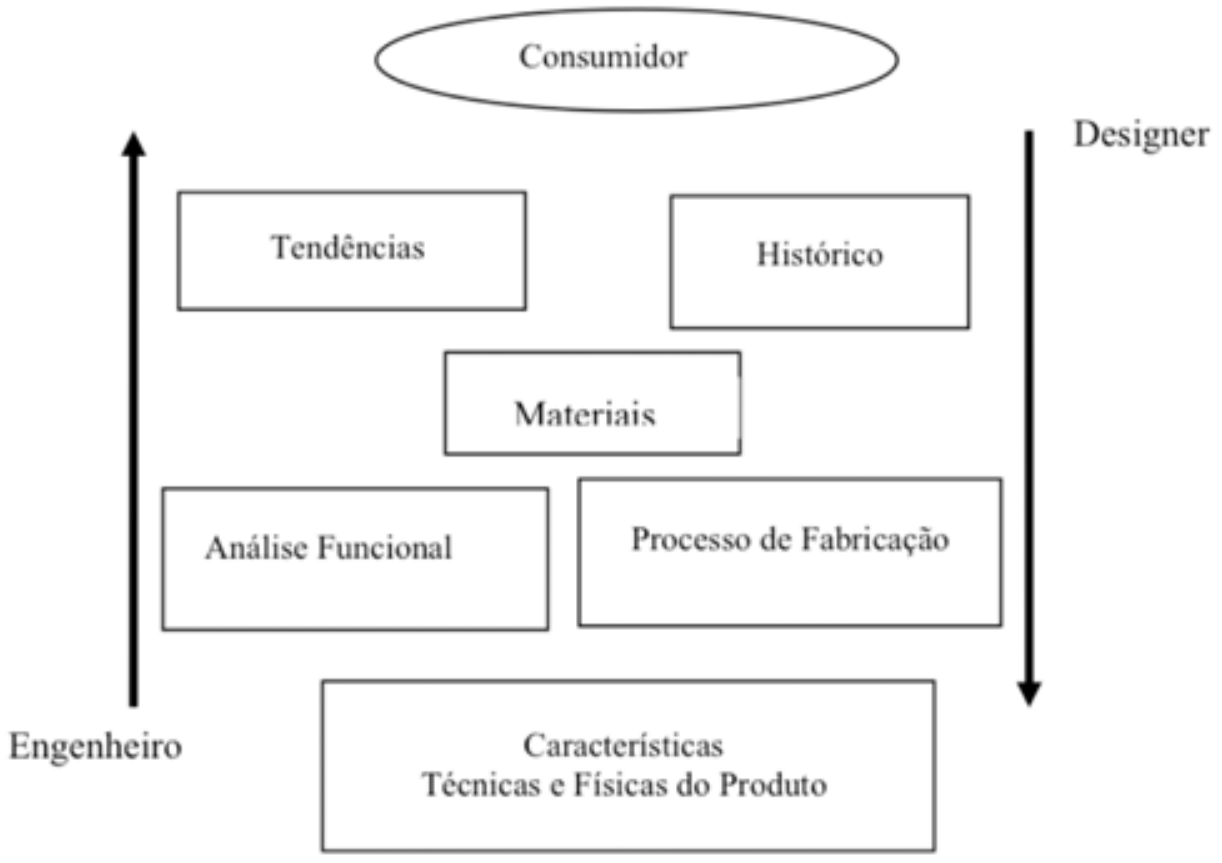

Figura 2.16 - "Lógica invertida" dos designers e engenheiros FONTE: KINDLEIN, 2006

TOVEY (1997) comenta que os designers industriais na indústria automotiva tendem a enfatizar os processos do hemisfério direito - processamento simultâneo, sintético, concreto e holístico; o hemisfério esquerdo, mais utilizado pelos engenheiros - processamento linear, verbal, analítico e linear (ver Figura 2.17).
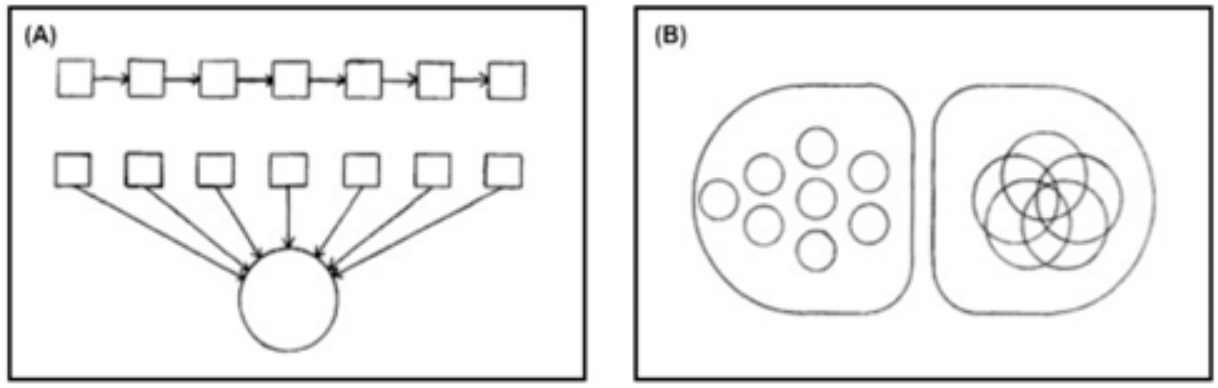

Figura 2.17 - Representação gráfica dos processos de pensamento relacionada aos lados do cérebro

FONTE: adaptado de TOVEY, 1984, p.220. (A) Superior: processamento linear (hemisfério esquerdo); Inferior: processamento simultâneo (hemisfério direito); (B) Esquerda: funções no hemisfério esquerdo são mais focalizadas; Direita: funções no hemisfério direito são localizadas de forma mais difusa. 
SMETS e OVERBEEK (1994, p.176) indicam que existem questionamentos por parte dos engenheiros sobre como tornar mais objetiva a subjetividade inerente a esta área do conhecimento utilizada pelo design industrial. "Os engenheiros querer saber como eles podem utilizar teorias da percepção e os resultados para chegar a novas tecnologias e projeto de produtos ótimos. Eles querem saber como projetar produtos para expressar visualmente propósito e significados."

As diferenças nos processos de pensamento parecem ser relevantes a ponto de influenciar a escolha pelos cursos de engenharia ou design industrial e também sua atitude e desempenho em relação ao projeto no início dos cursos.

LEE e RADCLIFFE (1990), ambos professores de departamentos de engenharia mecânica, conduziram estudo para entender a escolha dos alunos entre os cursos de design industrial e engenharia mecânica e o seu desempenho inicial no projeto de produtos, onde o resultado demonstrou que os estudantes do curso de design industrial foram sensivelmente melhores em todas as habilidades de projeto em relação aos alunos do curso de engenharia mecânica.

\footnotetext{
"Há uma clara diferença na atitude de projeto entre os estudantes de engenharia [projeto] e design industrial. [...] Sua habilidade [dos estudantes de design de primeiro ano] para lidar com os problemas de projeto, sua consciência técnica, sua percepção da necessidade de informação apropriada e suas habilidades de sketching foram todas compatíveis com seu desejo de se tornarem designers industriais. Isto oferece evidência para a segunda hipótese - que a habilidade inata dos estudantes reflete sua escolha de curso. Deve ser apontado que enquanto a carreira de um estudante de design industrial será demonstravelmente focada em projeto, enquanto o estudante de engenharia mecânica pode ter muitos focos, apenas um é projeto. Isto pode explicar em parte a diferença significante nas habilidades de projeto destes dois grupos de iniciantes" (LEE e RADCLIFFE, 1990, p.106)
}

\subsubsection{Consequências gerais}

As consequências de todas estas diferenças, as mais enraizadas, do individuo, e aquelas que se manifestam durante o projeto de forma técnica e prática, são provavelmente 
responsáveis por parte dos problemas normalmente observados na integração destas duas áreas de conhecimento no processo de desenvolvimento de produtos.

“Normalmente na equipe de concepção de produto, o designer fornece ao engenheiro um processo de desenvolvimento no qual as características estruturais e funcionais são deficitárias. O engenheiro elabora produtos muito funcionais e com características técnicas claramente dominadas, mas que não leva em conta o afeto do consumidor (percepção, cor, forma, textura)". (KINDLEIN, 2006, p.7)

Esta observação é provavelmente muito familiar a designers e engenheiros de qualquer porte de empresa, pois é muito comum que respondam de forma similar quando questionados sobre a participação do outro profissional no processo.

KINDLEIN (2006) continua, afirmando que a resolução dos problemas de comunicação não é simples. Para o designer será difícil passar diretamente de um produto físico à equação matemática que caracteriza o seu comportamento; para o engenheiro será difícil pensar diretamente em valor de estima.

São diversas as disfunções causadas no processo de desenvolvimento de produtos devido a estas diferenças. A mais evidente delas é provavelmente a falta de respeito ao conhecimento e a importância do outro profissional - até mesmo preconceito - o que ocasiona prejuízos difíceis de serem mensurados ao processo.

MOODY (1980) comenta este aspecto com termos utilizados pelos engenheiros para definir a contribuição do design industrial ao processo:

"A terminologia usada por engenheiros para descrever este estágio do desenvolvimento de produto [em relação ao design industrial] é esclarecedora sobre sua atitude a respeito. Descrito de várias formas como "decorar o produto", dar ao 
produto um "facelift"45 ou "estilizar" o produto, há conotações de sexismo e desprezo; o homem chauvinista por analogia revelando suas preferências ou escárnio pelos apelos femininos ou beleza, de forma geral." (MOODY, 1980, p.331).

“[...] Outra visão do design [industrial] é tida pelos engenheiros. Eles admitem que a aparência de um produto tenha alguma influência na sua aceitação comercial, embora eles tenham dificuldade em formular a natureza exata desta influência. Eles a consideram como uma inexplicabilidade do mercado, para a qual se deve fazer algumas concessões; eles tacitamente admitem que preferências irracionais do mercado existam, as quais devem ser conciliadas com a função técnica do produto se vendas precisam ser conquistadas. Eles consideram o problema como uma irritação de menor importância. É visto como um problema para ser negociado quando todo o resto foi feito; um problema que não deve ser levado tão a sério, que deveria ser resolvido com o mínimo de trabalho ou gasto de recursos. Uma solução comum é o tratamento cosmético da montagem funcional que surge durante o desenvolvimento técnico." (MOODY, 1980, p.330, grifo nosso).

"Algumas empresas aparentam considerar o design [industrial] simplesmente como o meio de produzir os desenhos em escala que são utilizados para fazer equipamentos. Esta visão é normalmente acompanhada por um conceito muito simplista de um produto: é considerado como a montagem física de componentes mecânicos, elétricos e eletrônicos que fazem o todo, a disposição destes componentes, sendo determinados pelos imperativos do funcionamento técnico." (MOODY, 1980, p.330).

BONSIEPE (1997) sintetiza a situação ao afirmar que na América Latina, e particularmente nas empresas orientadas à tecnologia (engineering-driven), o design tornou-se um fenômeno marginal, pois transcende os critérios tradicionais da engenharia. A tentativa de compreender o design através desta perspectiva encontra dificuldades. Geralmente acaba no juízo - ou preconceito - de que o design seria nada mais do que cosmética, limitando-se a agregar alguns traços decorativos aos projetos provenientes dos departamentos de engenharia.

Com a transformação do design industrial em algo marginal, secundário, menos importante, perde-se grande parte da sua verdadeira contribuição ao processo de desenvolvimento de produtos.

MOODY (1980) coloca que o design preenche a lacuna entre tecnologia e os usuários, mas como seus componentes são essencialmente não-científicos, a apresentação do produto é

\footnotetext{
${ }^{45}$ Trad. do autor: Cirurgia cosmética para remover rugas indesejadas através do esticamento da pele do rosto. Figurativo: Procedimento tomado para melhorar a aparência de alguma coisa.
} 
vista por muitas empresas e seus engenheiros como uma tarefa que pode ser feita por qualquer um com um módico bom senso. Inevitavelmente, o resultado é amadoresco.

HOLT (1989, p.164), ao comentar sua própria experiência como engenheiro em início de carreira - conforme o trecho completo citado anteriormente na abertura deste sub-tópico descreve uma situação crítica e indesejável, mas que considera típica do engenheiro:

\begin{abstract}
"Minha abordagem foi sempre a mesma, a do típico engenheiro. Tendo encontrado um princípio físico que ofereceria um conceito útil para a solução do problema assumido, minha energia foi concentrada na seleção de materiais adequados e encontrar formas e dimensões tanto da configuração total como das várias partes. Durante todo o processo o usuário foi negligenciado, se lembrado de qualquer forma."
\end{abstract}

WICKSTROM (1981* apud HOLT, 1989), observa que parece que a maioria dos produtos foi desenvolvida para homens com 30 anos de idade com força total em suas mãos e excelente visão; obviamente, a maioria dos usuários não se encaixa nesta descrição - eles não são usuários ideais nem do ponto de vista fisiológico nem psicológico. Termina por afirmar que os engenheiros deveriam começar seu trabalho pela consideração de como as pessoas funcionam, o que elas são capazes de fazer.

O IfM (IFM, 2007) relacionou os estágios do PDP com os respectivos problemas comumente encontrados - e que impedem as empresas de obterem produtos com "bom design”. O Quadro 2.3 organiza e relaciona as fases e os problemas. Em negrito, na coluna “problemas comuns", foram destacados os problemas, de acordo com o esforço realizado neste capítulo, mais relacionados com a lacuna cultural.

\footnotetext{
* WICKSTROM, S. Statement in a radio programme: The engineer does what he likes; the user has a problem. Norwegian Broadcasting System, 8 August 1981
} 
Quadro 2.3 - Fases do PDP e respectivos problemas comuns

\begin{tabular}{|c|c|c|c|}
\hline & & Descrição & roblemas comuns \\
\hline 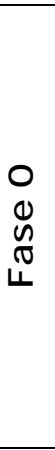 & 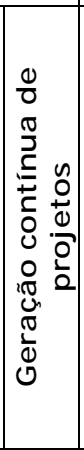 & $\begin{array}{l}\text { Existe uma gama de atividades de } \\
\text { pré-projeto que são críticas para } \\
\text { garantir que um bom fluxo de idéias } \\
\text { para que novos produtos sejam } \\
\text { gerados. Igualmente importante é a } \\
\text { avaliação e filtragem de idéias } \\
\text { potenciais, para garantir que apenas } \\
\text { as idéias potencialmente vencedoras } \\
\text { sejam levadas à próxima fase. }\end{array}$ & $\begin{array}{l}>\text { "Boas idéias" insuficientes, resultado da falta de } \\
\text { atividades adequadas de marketing e pesquisa } \\
\text { > Tendência aos conceitos "orientados à tecnologia", em } \\
\text { empresas dominadas pela engenharia } \\
\text { > Gerenciamento de portfolio de projetos pobre, resultando } \\
\text { em projetos demasiados e recursos insuficientes } \\
\text { > Nenhum envolvimento de designers industriais para } \\
\text { ajudar a construir conjuntamente as perspectivas de } \\
\text { mercado e tecnologia } \\
>\text { Oportunidades de plataforma e modularidade não- } \\
\text { exploradas }\end{array}$ \\
\hline 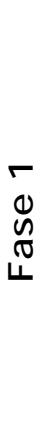 & 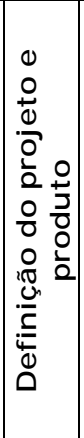 & $\begin{array}{l}\text { Estabelece-se a viabilidade técnica, } \\
\text { comercial e critérios do sucesso de } \\
\text { um projeto. Requer profunda } \\
\text { compreensão das necessidades dos } \\
\text { usuários potenciais, do ambiente, das } \\
\text { condições de uso e dos benefícios que } \\
\text { serão entregues na forma de um novo } \\
\text { produto. O resultado primário é } \\
\text { normalmente uma especificação de } \\
\text { produto detalhada e um "business } \\
\text { case" claro, para justificar o } \\
\text { investimento necessário. }\end{array}$ & $\begin{array}{l}\text { > Pobre compreensão do mercado, com pouca atenção à } \\
\text { segmentação do mercado global e posicionar claramente o } \\
\text { novo produto proposto } \\
\text { > Compreensão inadequada dos requisitos relativos aos } \\
\text { usuários e "visão" de produto pobre, baseada em } \\
\text { características em detrimento de benefícios } \\
>\text { "Business case" fraco, baseado em "guesstimates" [algo } \\
\text { como o brasileiro "achômetro" ou "chutômetro"] sem } \\
\text { fundamentação da potencial oportunidade } \\
>\text { Pouca consideração dos riscos técnicos, comerciais e de } \\
\text { mercado. }\end{array}$ \\
\hline $\begin{array}{l}\mathbf{N} \\
\mathbb{1} \\
\text { प } \\
\mathbb{L}\end{array}$ & 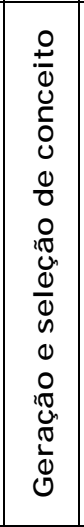 & $\begin{array}{l}\text { Definida a oportunidade potencial e } \\
\text { especificadas as características de } \\
\text { uma solução promissora, a fase de } \\
\text { geração de conceitos visa garantir a } \\
\text { busca divergente para possíveis } \\
\text { soluções. São estabelecidas } \\
\text { arquitetura do produto e questões } \\
\text { como usabilidade. Há decisões críticas } \\
\text { que exigem uma integração fina entre } \\
\text { designers industriais e engenheiros } \\
\text { projetistas especialistas. }\end{array}$ & $\begin{array}{l}\text { > Falta de criatividade durante a geração de conceitos e } \\
\text { tendência para escolher a primeira solução } \\
\text { > Integração pobre entre design industrial e engenharia } \\
\text { de produto, resultando em conceitos "estilosos mas } \\
\text { improdutíveis" ou "práticos mas feios". } \\
\text { > Falta de planejamento formal da arquitetura de produto, } \\
\text { conduzindo à proliferação de componentes e ineficiência } \\
\text { posterior da produção } \\
\text { > Pouca prototipagem ou testes de idéias, resultando em } \\
\text { mudanças tardias no design, conforme os problemas são } \\
\text { encontrados } \\
>\text { Ausência de análise das implicações nos custos pra } \\
\text { implementação das soluções de design }\end{array}$ \\
\hline 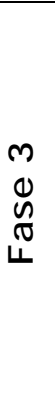 & 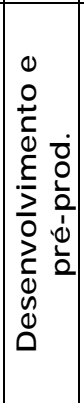 & $\begin{array}{l}\text { Com um conceito geral aceito, este } \\
\text { deve ser traduzido numa realidade } \\
\text { reprodutível e vendável. Na maioria } \\
\text { das vezes, esta é a fase mais longa } \\
\text { (em tempo transcorrido), onde } \\
\text { protótipos e ferramental são } \\
\text { confeccionados. É vital que o produto } \\
\text { não se distancie do conceito original, } \\
\text { enquanto o detalhamento da } \\
\text { engenharia e decisões de design são } \\
\text { realizados. }\end{array}$ & $\begin{array}{l}\text { > Envolvimento tardio do design industrial para } \\
\text { "maquiar" um produto desenvolvido pela engenharia } \\
\text { > Dificuldades técnicas devido ao gerenciamento de risco } \\
\text { pobre e insuficiente prototipagem precoce } \\
>\text { Coordenação e comunicação pobre entre grupos } \\
\text { funcionais } \\
>\text { Falta de envolvimento posterior [após definido o } \\
\text { conceito] do design industrial, resultando em um } \\
\text { "produto engenheirístico", que perdeu as características } \\
\text { do conceito original }\end{array}$ \\
\hline
\end{tabular}

FONTE: adaptado de IFM, 2007

O esforço deste capítulo em delinear preliminarmente a citada lacuna cultural baseouse em ampla revisão da literatura, num processo investigativo e indiciário. As diferenças 
encontradas entre design industrial e engenharia - e, consequentemente, entre designers e engenheiros, podem ser classificadas em quatro grupos:

a) diferenças na natureza e objetivos de projeto;

b) diferenças nas metodologias e técnicas de projeto;

c) diferenças nos critérios de aprovação e indicadores de sucesso;

d) diferenças psico-fisiológicas e cognitivas.

Acredita-se que nestas diferenças reside o cerne do que alguns autores citaram como lacuna cultural e boa parte dos problemas para a adequada integração entre as duas disciplinas no processo de desenvolvimento de produtos, como foi demonstrado nas consequências que puderam ser identificadas. Parece adequado supor que estas diferenças possam influenciar na decisão de adotar ou não o design industrial no PDP, na forma (intensidade, fase, responsabilidades, expectativas) como será adotado, na forma como a integração ocorre nas atividades de projeto e no relacionamento entre os profissionais. 


\section{PROPOSTAS PARA O ESTUdO E A PRÁTICA: FRAMEWORK E "BOAS PRÁTICAS"}

O caminho trilhado até agora permite estabelecer um conjunto de pressupostos que se articulam, indicando que a eficácia do PDP está vinculada à integração do design industrial e da engenharia, de forma a projetar produtos que obtenham boa performance de interface, além da performance técnica.

A revisão bibliográfica indica que, apesar de existirem evidências sobre os benefícios da integração do design industrial ao PDP para o aumento do sucesso das empresas no mercado, muitas empresas, especialmente as de menor porte, relegam para um segundo plano ou negligenciam a integração do design à engenharia no processo, bem como enfrentam problemas uma vez que tenham decidido pela integração.

Naturalmente, se trata de um fenômeno complexo, com múltiplas variáveis se relacionando e influenciando mutuamente em diversos níveis. Assim sendo, sentiu-se a necessidade de referenciais para a abordagem do problema de forma mais sistemática e ampla, pois a literatura mostrou-se fragmentada e os estudos tendem a abordar o problema de forma parcial, dependendo dos objetivos e da área do conhecimento com que enxergam o problema.

Resolveu-se assim, de forma ambiciosa, propor ferramentas conceituais e práticas para abordar o problema, de acordo com os objetivos deste trabalho: um ramework $^{46}$, que possa ser utilizado como orientação para o estudo deste tipo de fenômeno, construído com base nas evidências fornecidas pela literatura e pela prática; uma "Boa Prática" primária,

\footnotetext{
46 Uma estrutura básica, subjacente a um sistema e/ou conceito, que pode ser utilizada para a orientação e construção de correlações mais elaboradas.
} 
desejável para a integração entre design e engenharia; "Boas Práticas" secundárias, que possam ser aplicadas na prática para maximizar a implantação da prática primária; acredita-se que as duas últimas podem ser utilizadas tanto para verificar a situação atual quanto para modificá-la. Este capítulo busca apresentar estas propostas.

\subsection{FRAMEWORK PARA ESTUDO DO FENÔMENO DA INTEGRAÇÃO ENTRE DESIGN E ENGENHARIA}

Com a ciência da impossibilidade de isolar neste trabalho exploratório as diversas variáveis que influenciam o fenômeno da integração do design à engenharia, buscou-se esboçar um panorama de fundo que permita delinear os contornos preliminares dos fatores que influenciam, ou podem influenciar, no fenômeno da integração do design industrial e da engenharia no PDP, especialmente nas empresas de menor porte. Foram identificados e articulados alguns fatores, a partir da literatura investigada e apresentada no capítulo anterior, que podem ser classificados em quatro classes ou dimensões: (i) os relacionados ao porte das empresas e suas especificidades; (ii) os inerentes ao próprio processo de desenvolvimento de produtos; (iii) os relacionados a uma pressuposta lacuna cultural entre designers e engenheiros; (iv) o ambiente, ou contexto, onde a articulação destes fatores se manifesta para desenvolver um produto tem, obviamente, influência em cada fator individualmente e na forma como se articulam (ver Figura 3.1).

Acredita-se que este delineamento de contorno preliminar, enquanto ferramenta conceitual, possa ser utilizado como um "mapa" para a leitura da realidade, estabelecendo uma relação de diálogo entre a teoria e as evidências empíricas relacionadas à integração entre design e engenharia no PDP, enquanto fenômeno. Trata-se de uma abstração, exercício caro à 
investigação científica, que pode servir como base para a construção de correlações mais precisas e sólidas.

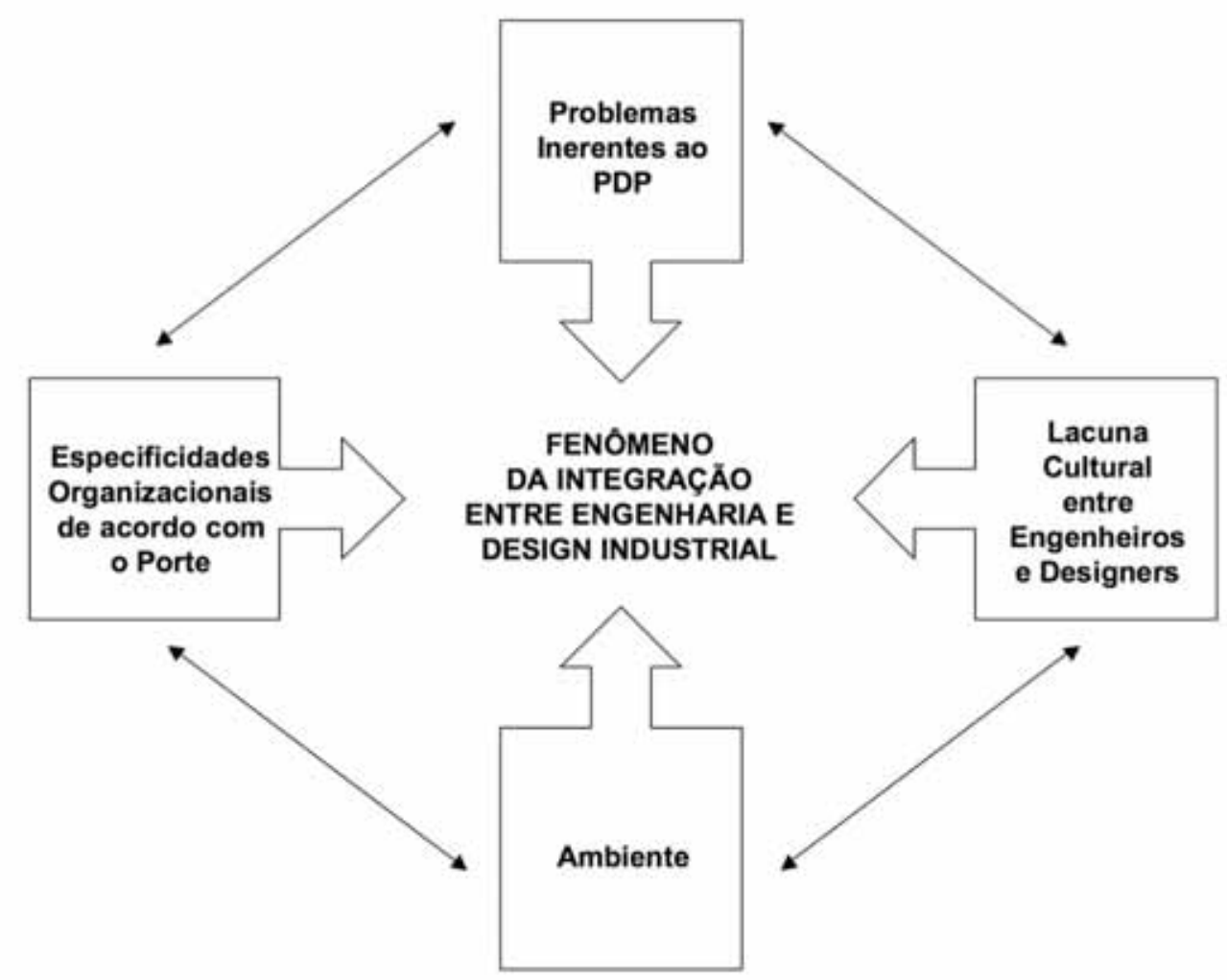

Figura 3.1 - Framework proposto para o estudo do fenômeno da integração entre engenharia e design industrial

Ao longo deste trabalho, será dada certa ênfase aos aspectos relacionados à terceira classe de fatores - lacuna cultural entre designers e engenheiros, pois se acredita que tem influência preponderante e são pouco estudados e compreendidos sistematicamente - o que não minimiza a influência real das outras classes.

\section{2. "BOA PRÁTICA" PRIMÁRIA - INTEGRAÇÃO PRECOCE}

Numa tentativa de compreender a essência, aquilo que é mais básico para a promoção da integração do design industrial à engenharia no PDP, buscou-se na literatura e em casos de empresas considerados exemplares neste aspecto, o que poderia ser uma "Boa Prática" 
Primária para tal. Acredita-se que esta "Boa Prática", por ser primária, e, portanto essencial, possa tanto servir como parâmetro para a investigação da realidade nas empresas brasileiras quanto para a modificação da mesma, caso não seja praticada.

GEMSER e LEENDERS (2001) colocam que empresas que focam no design industrial atualmente podem ser encontradas em uma ampla gama de setores, desde setores que tradicionalmente apresentam alta intensidade no uso de design industrial, como móveis ou iluminação, quanto setores modernos como computadores pessoais e produtos eletrônico de consumo.

O IFM (2007) coloca que, em diferentes mercados, o papel e a importância percebida do design industrial podem depender do modo e do tipo de competição. Em muitos mercados de produtos de consumo, design industrial é "característica de entrada" e diferenciação tem que ser obtida através de originalidade e custo. Em contraste, muitos produtos industriais competem através de vantagens técnicas, e o design industrial pode ser uma influência-chave na diferenciação. Em ambos os casos, é vital compreender como o design industrial pode entregar vantagem competitiva e em qual nível do modelo de maturidade a empresa e a concorrência se encontram.

$\mathrm{O}$ espectro do modelo de maturidade pode ser compreendido como a forma que o design industrial é entendido e, a partir deste entendimento, é envolvido no processo de desenvolvimento de produtos da empresa: do envolvimento tardio como "maquiagem de produto" ao envolvimento precoce no desenvolvimento da estratégia. Em última análise, o modelo de maturidade indica que, quanto mais precocemente a empresa envolver o design, maior o potencial de aproveitamento de sua expertise e consequentemente, maior a chance de resultar em um produto de sucesso. 
Na realidade, no nível mais alto do modelo, o design é envolvido antes da fase do projeto do produto propriamente dito, participando ativamente das fases de planejamento do produto e definição de portfolio de produtos, oferecendo insight, por exemplo, sobre o entrelaçamento entre tendências tecnológicas e comportamentos humanos, que podem se constituir em novos mercados frutíferos. Este fenômeno, muito atual, pode ser observado nas empresas de bens de consumo de maior sucesso, como a Philips e a Apple, entre muitas outras, que, inclusive, criaram há algum tempo a vice-presidência de design. Na perspectiva deste trabalho, esta situação não se constituirá em objeto de análise, limitando-se à integração do design nas fases do projeto de produto em si ("Processo de Projeto de Produto", do IfM, ou "Macro-Fase Desenvolvimento", de ROZENFELD et. al.). Através de uma sobreposição do modelo de maturidade do tipo "Escada do Design" com modelos de referência para desenvolvimentos de produtos, pode ser argumentado que a relação entre a "maturidade" e o processo de desenvolvimento tem base temporal ou cronológica, no sentido da fase em que é incorporado ao processo - embora modelos de referência sejam por definição, abstrações de uma realidade que não necessariamente ocorre de forma tão seqüencial. A Figura 3.2 é uma tentantiva de representar visualmente esta argumentação.

Tipicamente, as empresas que demonstram maiores níveis de ambição em relação à incorporação do design do que à competição podem adquirir significante vantagem comercial. Pode não ser necessário para todas as empresas operar no nível mais alto do espectro de integração do design, mas demonstrar suficientemente maior ambição de design do que sua competição. Entretanto, tanto utilizando o design industrial para orientar a inovação quanto utilizando para maquiar produtos, é vital que o designer seja envolvido precocemente e através do processo de desenvolvimento de produtos. (IFM, 2007) 


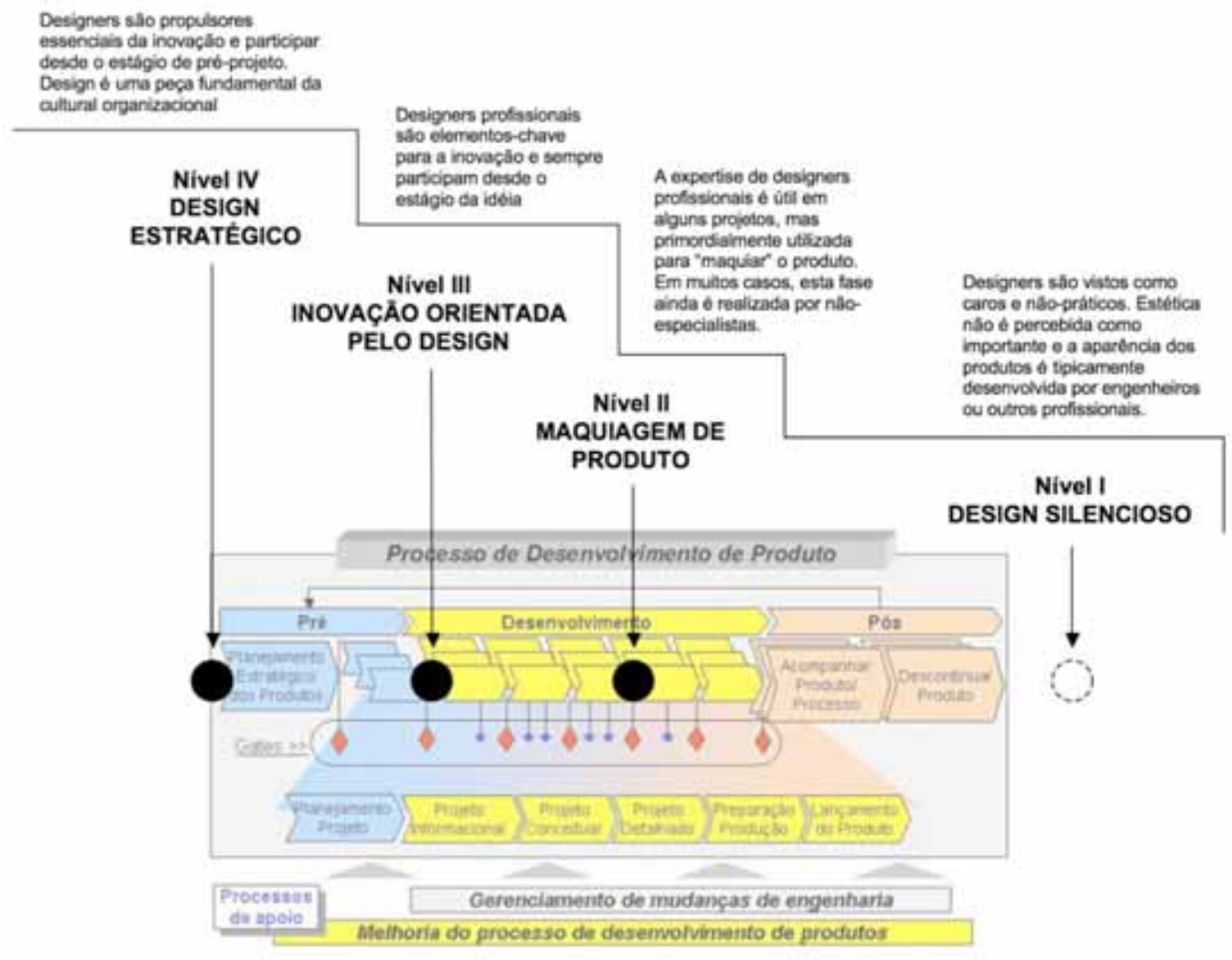

Figura 3.2 - Representação do nível de maturidade de design em relação à fase de integração no PDP

Vários outros estudos citam ou indicam a necessidade de envolver o design desde o

início do processo, por uma miríade de motivos, dos quais se citam abaixo apenas alguns:

"O custo de modificação aumenta ao longo do ciclo de desenvolvimento, pois quanto mais tarde for realizada uma mudança, um maior número de decisões já tomadas pode ser invalidado.” (ROZENFELD; VEGA, 1995, p.212).

“[...] O gerenciamento efetivo do processo de design necessita de uma abordagem integrada. [...] Desta forma, se design é questão de um processo que transcorre no tempo exigindo diferentes perspectivas, faz sentido organizá-lo de uma forma muito mais integrada. Ao invés de envolver pessoas sequencialmente, é caso para trazer o todo das diversas perspectivas conjuntamente logo no início e construir um conceito claro e compartilhado sobre quem deveria contribuir. Trabalho simultâneo envolve o trabalho compartilhado de todos estes diferentes grupos de pessoas conjuntamente, ao mesmo tempo, podendo ter um importante papel na organização e gerenciamento do processo de design. Envolvimento precoce deste tipo pode demonstravelmente reduzir a incidência de problemas nos estágios posteriores e também pode ajudar a lidar com o que de outra forma podem ser problemas complicados que ocorrem nas interfaces e passagens entre as fases [de projeto].” (WHYTE; BESSANT; NEELY, 2005, pg. 18, grifo nosso).

“A intervenção estética é novamente vista, cada vez mais, como um elemento-chave na competição, embora claramente distinta da 'maquiagem de produtos' [...]; é estrategicamente motivada, envolvendo designers industriais cedo e através do 
processo de desenvolvimento para criar relações emocionais entre produtos e consumidores." (LORENZ, 1994, p.75).

Pelo que foi discutido até o momento - incluindo os estudos relacionados aos modelos de maturidade - ficou claro que, a despeito das variáveis que influenciam o desenvolvimento de produto, quanto mais cedo o design industrial for integrado ao PDP, tanto melhor. Acredita-se, assim, que esta pode ser considerada uma "Boa Prática" central e primária:

\section{“É desejável a integração precoce do design industrial à engenharia no processo de desenvolvimento de produtos".}

\section{3. "BOAS PRÁTICAS” SECUNDÁRIAS}

A "Boa Prática" primária ou central exposta acima é a base para todo o processo de integração. Por outro lado, é de se esperar que sejam necessárias outras práticas que visem maximizar a chance de sucesso deste tipo de prática, uma vez adotada, considerando os tipos de problemas evidenciados pela literatura e pela prática.

Em consonância com os objetivos exploratórios deste trabalho, buscou-se observar, inferir, relacionar e, finalmente, propor um conjunto de "Boas Práticas" que pudesse ser aplicado ao PDP de empresas de pequeno porte. Estas "Boas Práticas" foram inferidas a partir da análise das características do processo de desenvolvimento, da filosofia e da estratégia explicítos ou implícitos - de empresas que poderiam ser classificadas no Nível IV do modelo de "Maturidade de Design", e confrontadas com orientações teóricas e iniciativas sobre estes aspectos encontradas nos escassas grupos que pesquisam o assunto. Com o conjunto de "Boas Práticas" definido, é possível avaliar o nível de adoção das mesmas por empresas brasileiras de pequeno porte, de forma a fornecer evidências sobre a situação atual em relação à adoção e 
integração do design industrial no PDP. Também é possível a comparação de produtos originalmente desenvolvidos pelas empresas com os mesmos produtos desenvolvidos adotando as "Boas Práticas", de forma a mensurar sua eficácia e eficiência e permitir definir melhor os contornos da integração entre design e engenharia no PDP de empresas brasileiras.

A seguir é apresentada a análise das empresas e grupos de pesquisa que resultou no conjunto de "Boas Práticas" proposto neste trabalho. Embora algumas das práticas possam ser identificadas em modelos de referência para desenvolvimento de produtos, os casos de empresas analisados se destacam por integrar o design industrial nos processos com sucesso, notoriamente colocando-o em um papel central no processo.

\subsubsection{IDEO}

A IDEO, estabelecida na Califórnia/EUA, é uma empresa de consultoria em desenvolvimento de produtos. É relevante para este trabalho a dimensão que esta empresa, que baseia seu processo de desenvolvimento no design industrial - tendo o user-centred design como orientador do processo, tomou.

É reconhecida internacionalmente, tendo desenvolvido produtos para a maioria das empresas da lista da revista Fortune, que elenca as 500 maiores empresas do mundo ${ }^{47}$. Nos últimos anos, mais do que desenvolver produtos para estas empresas, tem sido chamada para ensinar as empresas a implantar um processo de aumento da inovação, baseado nas metodologias do design industrial - denominado design thinking. A IDEO (IDEO, 2007) ajuda organizações a inovar através do design. Independentemente classificada por líderes de negócios globais como uma das 20 empresas mais inovadoras do mundo, utiliza sua

\footnotetext{
47 Alguns clientes da IDEO: Airbus, Altec, Lansing, BBC, BMW, Bank of America, Cargill, Electronicarts, Eli, Lilly, Forest, City, Hasbro, Hewlett-Packard, Intel, Kaiser, Permanente, Kraft Foods, MayoClinic, McDonald's, Medtronic, Microsoft, Motorola, NASA, Nestle, Nokia, Olivetti, PepsiCo, Pfizer, Consumer, Health, Procter, \&, Gamble, Samsung, SAP, Shimano, Stanford University, Thomson, Visa, Vodafone, Zyliss.
} 
abordagem baseada no design para ajudar clientes a navegar na velocidade, complexidade e áreas de oportunidade do mundo atual. Contribuiu para o design e desenvolvimento de muitas inovações que se tornaram padrões, incluindo o primeiro mouse (para o primeiro computador Apple) e o primeiro notebook (Grid Computer). Diversos outros produtos de sucesso fazem parte do seu rol de realizações: Palm V, Handspring Treo, Polaroid i-Zone, Oral-B Kids. Sua equipe tem aproximadamente 500 "pensadores do design" ${ }^{48}$, como gostam de chamar os membros da equipe, independentemente da sua formação, experts nas disciplinas de design, engenharia, ciência social e estratégias de negócios. Possui escritórios em São Francisco, Palo Alto, Chicago, Boston, Londres, Munique e Xangai. Seus diretores são constantemente convidados para palestrar sobre design, inovação e criatividade como valores estratégicos e são professores de Stanford e do MIT, tendo publicado vários livros.

Segundo o próprio site da empresa (IDEO, 2007), os times multidisciplinares são o coração do método da IDEO, denominados hot teams. Utilizam-se profissionais de ergonomia (human factors), negócios, design de interação, engenharia mecânica, engenharia elétrica, manufatura, engenharia de software, saúde, design centrado na criança ${ }^{49}$, meio-ambiente, entre outros. Para a empresa, “o design industrial se preocupa com a experiência tangível de ver, desejar, obter e utilizar o produto, em última instância definindo a conexão emocional do usuário com o objeto".

Os designers industriais da IDEO são envolvidos no projeto desde a estratégia inicial e conceitual até a implementação detalhada da produção, integrando os aspectos essenciais do negócio, ergonomia (human factors) e aspectos técnicos, identificados pelo cliente e pelo time de design. A empresa alega que

\footnotetext{
${ }^{48}$ No original: design thinkers

${ }^{49}$ No original: kid-centric design
} 
"ajuda organizações de negócios, do governo, da educação e de setores sociais a inovar e crescer de três formas: (i) identificando oportunidades para crescimento através da revelação de necessidades latentes, comportamentos e desejos das pessoas, percebendo novas formas de servir e atendê-los; (ii) visualizando novos caminhos para empresas e marcas, projetando sua oferta - produtos, serviços, espaços, mídia e interações de software, que os trazem à vida; (iii) habilitando as organizações para mudar sua cultura e construir as capacidades exigidas para a inovação sustentável.” (IDEO, 2007)

Tim Brown, $C E O$ da IDEO, foi convidado para participar de vários fóruns no encontro de Davos, em 2006, o que pode ser uma evidência sobre a importância do design na estratégia das nações. Segundo sua visão, o design pode ser utilizado para muitas coisas, mais do que deixá-las bonitas. Existem empresas que utilizam o design thinking como uma forma de criar seu futuro, sendo este tipo de processo de pensamento uma abordagem para a inovação (IDEO, 2006). Sobre a participação da empresa de design no fórum, Bruce Nussbaum, que escreve semanalmente sobre design na revista americana de negócios Business Week, comentou:

"[...] duas coisas, ao menos, são claras. Primeiro, executivos de corporações globais estão convencidos que inovação e criatividade são críticos para o sucesso futuro das suas empresas. Segundo, para fazer isso acontecer, uma caça massiva por talentos criativos ao redor do mundo está acontecendo.” (IDEO, 2006).

KELLEY e LITTMAN (2001) descrevem alguns dos "segredos" da IDEO, desvelando os pilares do seu método de inovação baseado no design - design thinking:

- Hot Teams: times multidisciplinares trabalham do início ao fim do projeto, com todos participando de todas as fases;

- Brainstorming: as reuniões para brainstorm, o pensamento divergente e a “polinização-cruzada" são estimulados; todos participam sem restrições e tudo é permitido para se investigar problemas e soluções;

- Técnicas de investigação centradas no usuário: todos do time de projeto são estimulados a coletar informações sobre o usuário, indo fazer compras, utilizando os produtos, entendo no papel do ser humano nos seus momentos consumidor/usuário; 
- Prototipagem frequente: todos os conceitos mais promissores são prototipados, utilizando-se desde fita adesiva, papelão e isopor até prototipagem rápida; são confeccionados e testados quantos protótipos forem necessários ao longo do processo.

\subsubsection{Apple}

A Apple Computer, com sede em Cupertino, Califórnia, é reconhecidamente uma empresa altamente inovadora, não somente no Vale do Silício, mas no mundo. Há algum tempo vem sendo considerada como um modelo para o mundo dos negócios, devido à sua capacidade de inovar em seus produtos e, mais do que vender eletrônicos, vender bens de consumo desejados e venerados por todos.

Inovadora desde a sua criação, por volta de 1978, lançou o primeiro computador pessoal, o sistema operacional baseado em GUI - Graphic User Interface (MacOS), o mouse, o Macintosh, o iMac e uma série de inovações de ponta, que culminou nos recentes sucessos estrondosos do iPod e do iPhone. Mais do que desenvolver tecnologia, hoje é consenso que o segredo da Apple é atender adequadamente às necessidades humanas, especialmente as psicológicas, cognitivas e sociais, oferecendo produtos bonitos, fáceis de utilizar e que se transformem em símbolos de status e desejo. A Apple é uma empresa baseada no design.

Sobre a importância do design na Apple, a introdução do iMac não apenas ampliou sua fatia de mercado e lucros, mas também iniciou uma tendência orientada ao estilo e moda em computadores pessoais (GEMSER e LEENDERS, 2001). O mesmo pode ser dito sobre o iPod, um fenômeno de vendas mundial que chegou ao ponto de se tornar um ícone ubíquo e o recente iPhone, numa quebra de paradigma que reinventou a forma como se utiliza um celular multifuncional, muito pela tecnologia aplicada, mas mais ainda pela forma inovadora como a interface desta tecnologia é feita com o ser humano. 
ELGAN (2007) argumenta que é possível dividir os fabricantes de eletrônicos de consumo em dois grupos: Apple e o resto. Sua influência no mercado global é de diversas ordens de magnitude superior a de qualquer competidor próximo. Ela engendra lealdade nos consumidores de forma significantemente maior do que é ganho por qualquer outra empresa de eletrônicos; sua marca e seu reconhecimento na cultura geral excedem grandemente o que seria esperado, dado as vendas atuais da empresa. Alguns dos seus segredos - poder-se-ia denominar "Boas Práticas" são:

- A engenharia ajuda o design - sem exceções: a maioria das empresas traz os designers tardiamente no processo de desenvolvimento de produtos para criar uma embalagem $^{50}$ ao redor de todas as funcionalidade e tecnologias que os engenheiros e o pessoal de marketing criaram. Na Apple, os designers ditam as regras, desenvolvendo como o produto irá parecer, ser sentido e funcionar, e os engenheiros são chamados a fazer isto acontecer;

- Menos é melhor: muitas empresas dão muito poder para analistas de marketing e substituem uma visão de produto, resultando em supersegmentação. A Apple tenta desenvolver o menor número possível de produtos, com apelo para o maior número possível de pessoas. A sobreposição de características é perto de zero, permitindo aos usuários pouca ansiedade em descobrir qual o produto que melhor se encaixa em suas necessidades;

- A experiência é o produto: o produto vai além do aparato técnico, mas envolve todos os pontos de contato com o usuário/consumidor: da embalagem, ao manual; da loja ao estacionamento;

- Não se pode agradar a todos. Então, agrade pessoas com bom gosto: pesquisas de marketing levadas a cabo por empresas para descobrir o que elas querem são um problema,

\footnotetext{
${ }^{50}$ No original: experience wrapper
} 
pois as pessoas são pouco precisas ou não sabem o que querem - ou não sabem expressar em palavras.

- A filiação de grupo é a tônica: "a mãe de todos os segredos", que explica porque as pessoas compram os produtos Apple. A identidade é uma motivação primária humana e um dos maiores componentes da identidade pessoal é a filiação a um grupo - observável através da defesa ferrenha que os "macmaníacos" fazem dos produtos da Apple. As pessoas querem pertencer a um grupo que imediatamente os identifique como sendo superior às outras pessoas em outros grupos. Comprar um laptop, um tocador de mídia ou celular é como comprar roupas ou um carro (...); é menos sobre funcionalidade e mais sobre o que o objeto comprado diz para as outras pessoas sobre quem você é a qual grupo pertence.

É perceptível a relação destas práticas com o design industrial: o projeto centrado no usuário, não apenas na ergonomia e estética, mas no atendimento de necessidades intangíveis como os simbólicos e psico-sociais; o projeto de uma "experiência" ampla, ao invés de projetar um aparato tecnológico; a simplicidade no uso e o foco no benefício do produto, ao invés das características técnicas.

É claro, também, a partir da primeira prática/segredo, que o design industrial desempenha um papel importante, não apenas participando desde o início, mas sendo central, não sendo limitada pelas engenharias como normalmente acontece. Esta noção é reforçada nas palavras de Steve Jobs, $C E O$ da Apple, ao comentar os erros cometidos pela maioria das organizações e afirmar que na Apple, o design é o ponto de partida e a base de tudo:

\footnotetext{
"O que acontece nas outras empresas é que os designers vêm com uma grande idéia, mas os engenheiros dizem que não podem fazer aquilo. E então o produto fica pior. Aí o projeto é levado ao pessoal da manufatura, que também diz que não pode construir aquilo. E então o produto fica muito pior. $\mathrm{Na}$ Apple, esse ciclo simplesmente não existe." (EXAME, 1997, p.27).
} 
Desta forma, podemos inferir como "Boas Práticas" principais aplicadas no PDP da Apple:

- O design industrial é envolvido desde o início;

- As diretrizes de design industrial são mantidas ao longo do projeto;

- O produto é desenvolvido de forma a atender a performance de interface, além da performance técnica.

\subsubsection{Philips}

A Philips é uma corporação holandesa que fabrica desde lâmpadas, até eletroeletrônicos de consumo e equipamentos da área médica. Sua sede é em Eindhoven, Holanda, cidade onde também se encontra o Design Center da TU Eindhoven, reconhecido centro de design industrial mundial. Não por acaso, a Philips mantém uma relação simbiótica com esta universidade.

Reconhecida como uma empresa altamente inovadora, evidências sugerem que a estratégia orientada pelo design da Philips ajudou a impulsionar as vendas de seus produtos de consumo para índices em torno do dobro da média da indústria (GEMSER e LEENDERS, 2001).

Para muitos é uma surpresa quando descobrem que a Philips não é uma empresa de tecnologia, apesar dos seus grandes centros de pesquisa e engenharia, mas uma empresa de design. Esta constatação fica clara nas palavras da própria empresa:

"Na Philips, 'design' é muito mais do que apenas criar produtos com um aspecto agradável. Na Philips, o 'design' é um elemento fundamental no processo de inovação e é utilizado em todo o Grupo Philips como um método de negócio. Todos os pormenores que compõem um produto são cuidadosamente analisados, desde a 
compra até à utilização real. Até mesmo a nostalgia - a recordação carinhosa que o consumidor tem do produto, depois de deixar de utilizá-lo - é tomada em consideração durante o processo de concepção. Na Philips, as disciplinas tradicionais de 'design' são integradas com os conhecimentos das ciências humanas e da tecnologia, através de uma abordagem multidisciplinar, baseada na pesquisa, que possibilita a criação de novas soluções que satisfaçam e antecipem as necessidades e aspirações das pessoas. A este novo e enriquecido tipo de 'design' damos o nome de 'High Design'. 'High Design' é uma filosofia e um processo concreto, integrado de forma flexível no negócio e nos processos de criação de produtos. A missão dos profissionais de 'design' da Philips é criar soluções que humanizem a tecnologia. A experiência em 'design' da Philips, em todas as áreas da concepção, é permanentemente atualizada através de programas de pesquisa que investigam os mais recentes desenvolvimentos e os aperfeiçoam ainda mais." (PHILIPS, 2007).

PHILIPS (2007) descreve o processo chamado pela empresa de "High Design" como uma filosofia de projeto, uma abordagem enriquecida que integra habilidades de projeto estabelecidas com outras disciplinas das áreas de ciências humanas, tecnologia e negócios. O processo de "High-Design" é:

- Focado nas pessoas: entregar soluções que não são apenas tecnologicamente possíveis, mas preferíveis do ponto de vista social, antropológico e pessoal;

- Multidisciplinar: garantir que todos os pontos de vista (pessoas, tecnologia e negócios) sejam considerados;

- Baseado em pesquisas: garantir que os resultados obtidos sejam baseados em fatos reais e continuamente expanda o conhecimento

O processo é estruturado em 5 fases:

- Fase de iniciação: entrega - compreensão compartilhada entre o time de projeto e o cliente sobre os objetivos e escopo de projeto;

- Fase de análise: pesquisa e otimização dos objetivos do projeto em relação às restrições de marketing, tecnologia e planejamento; 
- Fase de conceito: desenvolvimento de idéias e proposta de design;

- Fase de finalização: entrega de especificações de projeto;

- Fase de avaliação: avaliação do projeto entregue, do processo e da comunicação, para ser utilizado como input no futuro.

É possível inferir as seguintes “Boas Práticas” a partir da análise do apresentado acima:

- Atendimento da performance de interface é o objetivo último, além da performance técnica; foco nas necessidades psicológicas, cognitivas e sociais dos seres humanos para a aplicação tecnológica;

- Time-multidisciplinar, com áreas normalmente não ligadas ao projeto de produtos;

- Foco no design industrial, com suas diretrizes sendo mantidas ao longo do projeto;

- Envolvimento do design industrial desde o início do processo;

- Projetar produtos que "fazem sentido" para as pessoas e são simples (sense and simplicity).

Estas "Boas Práticas” são evidenciadas nas palavras de Stefano Marzano (ROUSOE, 2006), CEO \& Chief Creative Director da Philips, que acredita que as soluções deveriam ser criadas se elas melhoram a qualidade de vida, não apenas porque elas são tecnologicamente possíveis. Os produtos devem seguir a diretriz da simplicidade através da transformação da complexidade inevitável da vida em acessível, compreensível e clara. Embora exista discussão entre em diversos níveis financeiros e estratégicos da empresa, na Philips o compromisso com o design focado no ser humano se mantém constante. 
BLAICH (1989 apud MAGALHÃES, 1995, p.23), afirma que o design é algo importante demais para ser deixado nas mãos dos designers, pois tem que ser uma estratégia corporativa. Sobre sua experiência como diretor do Programa de Design Corporativo na Philips, conta que os projetos realizados com o designer sendo chamado no último instante fracassaram no mercado; por outro lado, qualquer projeto que o designer tenha feito independente das outras áreas nunca chegou ao mercado.

\subsection{4. $M I T$}

O Departamento de Engenharia Mecânica do MIT, conhecido como Mech-E, desenvolve pesquisas sobre a integração entre designers industriais e engenheiros.

Uma das atividades é a promoção de encontros regulares dos seus engenheiros com os designers industriais da IDEO, visando apresentar aos profissionais da área de exatas o tipo de pensamento e as metodologias do design industrial, criatividade e inovação. Além disso, espera-se que os engenheiros consigam adquirir habilidades além das analíticas, para que possam manter certa vantagem em relação aos engenheiros de outros países.

É possível destacar as seguintes "Boas Práticas" a partir da análise do apresentado na Figura 3.3:

- Brainstorming multidisciplinar;

- Prototipagem precoce e frequente;

- Conciliar processos do lado direito do cérebro (criatividade) com os do lado esquerdo (capacidade analítica);

- Conciliar bom design centrado no usuário com princípios de engenharia. 


\title{
department of mechanical engineering
}

\section{The Idea Factory}

\section{Industrial Design Firm IDEO Collaborates with MIT MechE to Teach Creativity to Engineering Students (Yes, it Can be Done)}

\author{
Jay Chrepta, Department of Mechanical Engineering \\ March 13, 2006
}

Two time Nobel prize winning chemist Linus Pauling once said, "The best way to get a good idea is to get a lot of ideas." This is one of many quotes used by Associate Professor of Mechanical Engineering David Wallace to inspire the beginning of each day of 2.670 - Mechanical Engineering Tools.

Over two two-week sessions during IAP, 160 sophomore mechanical engineering students take part in a crash course to design, build, and race a Stirling engine, leaming skills from sketching and CAD to machining and Matlab. This year, however, another focus not necessarily found in many standard engineering classes was added to the curriculum -namely how to be creative.

Although some might consider creativity an innate ability, Professor Wallace believes that "you can teach creativity. With a little practice, technique and encouragement, we can all leam to be more creative."

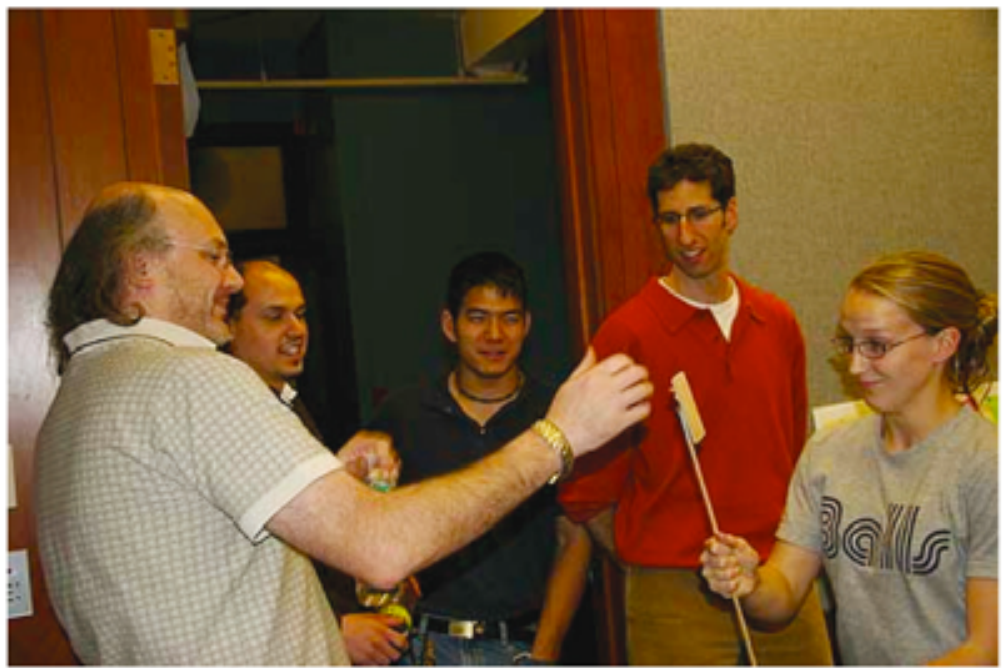
This year's 2.670 students had the opportunity to do just that under the tutelage of a team led by an MIT alumnus, who also happens to be a mechanical engineer at, arguably, the largest and most innovative design firm in the world.

Late in 2005, Linus Park (SB MechE 2002) of the global design firm, IDEO, approached Professor and Department Head of Mechanical Engineering Rohan Abeyaratne to investigate the possibility of an academic partnership. IDEO already had an established history working with major universities, most notably with Stanford University - from teaching classes to collaborating on Stanford's new Institute of Design, nicknamed the "d.school." Moreover, representatives from IDEO's Boston office were already involved with the MIT Sloan School of Business and had served as team design mentors and judges in mechanical engineering's 2.009 , the senior product design class, for the past six years.

Wth growing interest in 'educating the right brain', the time was right for MIT's Mechanical Engineering department to develop a more formal relationship with the company that, among the some 4,000 products designed in its history, developed the first production Apple mouse. Abeyaratne visited IDEO in December of 2005 and that's when, as Park said, "All of the pieces began to fall into place."

Park and a team from IDEO were invited to come teach two one-day seminars during 2.670 on brainstorming and

Figura 3.3 - Programa do Mech-E/MIT para integração do design (continua) 


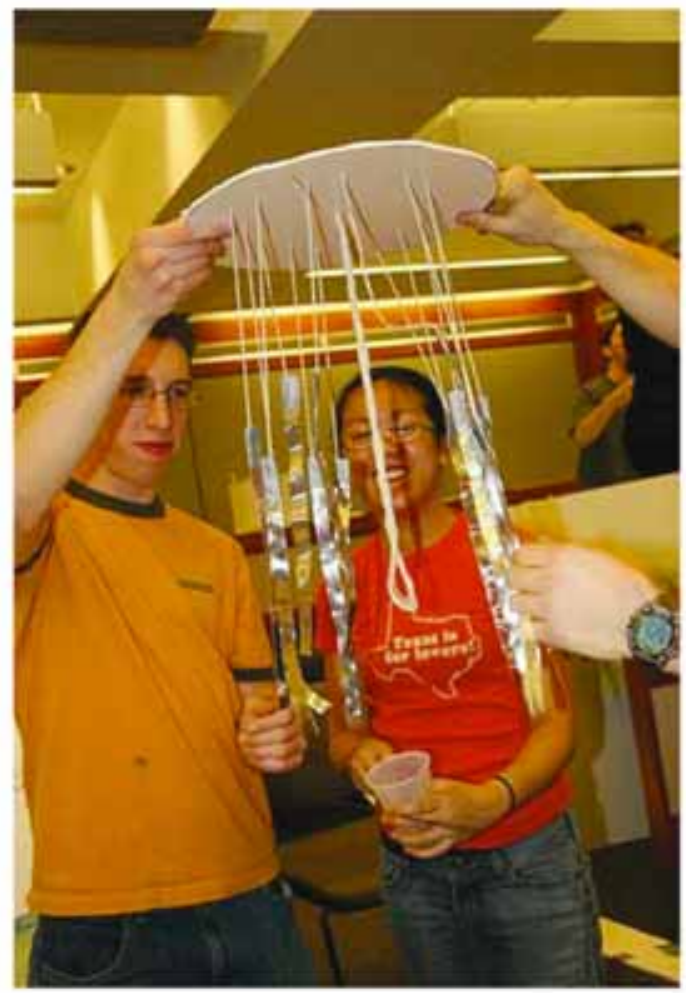

prototyping. two tools that both require and encourage creativity. A challenge developed by IDEO was posed to the students: quickly design and prototype a self-powered musical instrument using only a kit of random parts that. among an assortment of materials, included mouse traps, aluminum foil, and golf balls. Teams of 6-7 students with boatloads of left-brain analytical skills were forced to perform mental calisthenics on their collective right hemispheres. The emphasis was on creative problem solving, to develop the ability to rapidly switch between creative and analytical tasks

Park introduced several of IDEO's techniques to enhance creativity, idea generation, and prototyping -a structure. process, and even rules for how to come up with many innovative solutions to a problem. Under the helpful eye of several IDEO designers and engineers working with Park. the 2.670 students were immersed in the fast-paced methods of design innovation, coming up with a fun blend of clever disasters and uniquely successful solutions.

Reflecting on the outcome of the class, Park said, There is no guaranteed recipe for success when trying to teach creativify. Everyone has to find what works best for their own creative skills. We were fortunate enough that the students were willing to let themselves become fully engaged in the process we've developed at IDEO, and hopefully we were able to make them more aware of and teach them about their creative abilities.

IDEO's goal of partnering with MIT goes beyond the occasional classroom visit and guest speaking opportunity Park suggests the potential for U.S.-trained engineers to lose their competitive edge to engineers elsewhere around the world, an issue being highlighted in recent education news. As engineering education becomes less stratified globally and traditional engineering skilis become more established, it will be the ability of engineers to innovate and be creative that will distinguish them in the future. It is a mantra practiced and preached at IDEO, where creativity and innovation in combination with good user-centric design and engineering principles have been the foundations for IDEO's successful history

We hope to take advantage of any opportunity to bring more creativity and innovation into the classroom and to extend that collaboration to the amazing cutting edge research and development that occurs at MIT," states Park. Plans and improvements for the next 2.670 are underway, as well as several activities in the coming spring bringing IDEO to help teach the department's graduate product design class, 2.744

Int4

URL : http: KWwW-the mit eduStories 031006 ideo htmi

\begin{tabular}{|c|c|c|}
\hline$|1| \mid$ & $\begin{array}{l}\text { Department of Mechanical } \\
\text { Engmeenng }\end{array}$ & 77 Massachusetts Avenue \\
\hline
\end{tabular}

Figura 3.3 (cont.) - Programa do Mech-E/MIT para integração do design

A pesquisa de WALLACE e JAKIELA (1993), "A Computer Model of Aesthetic

Product Design: an approach to unify engineering and industrial design", do Departamento

de Engenharia Mecânica - Mech-E, buscou desenvolver um sistema CAD que possa integrar

o projeto conceitual de engenharia com o projeto de design industrial. Para desenvolver esta

ferramenta, os autores consideraram o design de produto a partir da perspectiva do 
consumidor, representada no processo pelo design industrial. O software deve poder gerar alternativas e conceitos de design baseados em manufatura, ergonomia, estética e considerações de estilo; ao invés das ferramentas analíticas da engenharia, concentraram-se nos aspectos menos quantitativos do projeto de produto. Espera-se que sistemas deste tipo integrem a fase conceitual da engenharia de produto (no original, conceptual engineering design) e design industrial num processo unificado. Os autores sentem que

\begin{abstract}
"o design moderno sofre de uma dualidade de abordagens, dependendo de como o design será julgado, útil ou belo. Falando amplamente, o designer industrial é embasado na visualização enquanto o engenheiro foca na performance. Os esforços dos designers industriais e engenheiros de produto são muitas vezes fracassos, mas claramente os produtos de consumo de sucesso requerem as habilidades tanto do designer industrial quanto dos engenheiros." (WALLACE e JAKIELA, 1993, p.2, grifo nosso)
\end{abstract}

SMYTH e WALLACE (2000, p.1, grifo nosso), em outra pesquisa com ênfase na integração, colocam que

\begin{abstract}
"A importância das considerações estéticas no projeto de produtos de consumo é clara. Enquanto produtos maduros como automóveis convergem em funcionalidade, esforços estão sendo feitos para diferenciar os produtos apelando para a reposta emocional dos consumidores. (...) Tradicionalmente, design industrial e engenharia de produto são vistos como atividades polarizadas no desenvolvimento de produtos de consumo. Esta tensão é evidente, na maioria das vezes, nos produtos resultantes. Onde a harmonia entre forma e função foi obtida, o fabricante muitas vezes investiu em muitas interações de projeto entre os pontos de vista do design e da engenharia. Numa era em que a tecnologia da informação está permitindo profissionais com diferentes backgrounds representar e comunicar idéias complexas, parece que esta lacuna entre engenheiros e designers industriais poderia ser preenchida para criar eficientemente projetos conceituais que conjuguem forma e função."
\end{abstract}

Pode-se inferir como "Boas Práticas":

- Integração da engenharia e do design industrial num processo unificado;

- Produtos de consumo de sucesso requerem as habilidades tanto do designer industrial quanto dos engenheiros. 
John Maeda ${ }^{51}$ é professor do Media Lab do MIT e membro do conselho consultivo da Philips, sendo responsável pela implantação do conceito de simplicidade em todos os produtos do grupo, como pode ser visto na campanha publicitária mundial que tem o mote Sense and Simplicity.

Em seu livro "As Leis da Simplicidade” (MAEDA, 2007), propõe dez leis e três "soluções" para balancear simplicidade e complexidade nos negócios, na tecnologia e no design, organizadas em conjuntos sucessivos de três leis, embora possam ser aplicadas independentemente. Segundo o autor:

\begin{abstract}
"Há três tipos de simplicidade discutidos aqui, em que o conjunto sucessivo de três Leis ( 1 a 3; 4 a 6; 7 a 9) corresponde a condições cada vez mais complicadas da simplicidade: básica, intermediária e avançada. Desses três agrupamentos, a simplicidade básica ( 1 a 3 ) é imediatamente aplicável à concepção do design um produto (...). Por outro lado, a simplicidade intermediária (4 a 6) é mais sutil em termos de sentido, e a simplicidade profunda (7 a 9) aventura-se em pensamentos que ainda estão amadurecendo. Se você quiser economizar tempo (...), sugiro que comece com a simplicidade básica e em seguida pule para a décima lei - A Única, que sintetiza todo o conjunto." (MAEDA, 2007, p.vi).
\end{abstract}

Entre as Leis, a primeira é Reduzir - não é necessariamente benéfico adicionar funções tecnológicas só porque podemos fazer isso; a segunda, as funções devem estar organizadas em uma hierarquia sensata para que os usuários não se distraiam com características e funções de que não necessitam; a décima, conhecida como "A Única", diz que a simplicidade consiste em subtrair o óbvio e acrescentar o significativo.

A teoria de Maeda é quase uma filosofia, que pode ser aplicada a diversos âmbitos da existência. No caso dos produtos, deve ser aplicada no projeto, com o objetivo de reduzir a complexidade. Reduzir a complexidade, no caso, está estreitamente relacionado com user-

\footnotetext{
${ }^{51}$ John Maeda foi considerado pela revista Times uma das dez pessoas mais influentes do mundo na atualidade. É designer gráfico e cientista da computação. É professor do famoso Media Lab do MIT, o mesmo de Nicholas Negroponte e fundador do MIT Simplicity Consortium. Já recebeu o Prêmio Nacional de Design do Smithsonian (EUA); o maior prêmio europeu de design da Raymond Loewy Foundation (Alemanha); o Prêmio Mainichi Design (Japão).
} 
centred design, isto é, disponibilizar a tecnologia, embarcada no produto, de forma adequada aos seres humanos.

Desta forma, pode-se inferir como "Boa Prática":

- O projeto de produtos deve ser orientado ao usuário

Acredita-se que não é possível, dado o nível de interação que as leis propostas exigem, envolver o design industrial numa fase avançada, quando muitas decisões que poderiam reduzir a complexidade já foram tomadas, inclusive porque algumas delas são relacionadas com atributos intangíveis e subjetivos. Ainda, desconsiderar os atributos intangíveis em favor dos tecnológicos, como é comum no PDP orientado apenas pelas engenharias, é fazer justamente o contrário do proposto. Desta forma, é possível inferir mais duas "Boas Práticas":

- Envolvimento do design industrial desde o início do processo;

- Consideração igualitária das diretrizes de design industrial e engenharia.

\subsubsection{Institute for Manufacturing (IfM)}

O Institute for Manufacturing (IfM) é parte do Departamento de Engenharia da Universidade de Cambridge, Reino Unido. Suas atividades alinham serviços industriais, pesquisa, educação e cursos que objetivam oferecer uma clara compreensão dos desafios, face à realidade de produção.

O IfM (IFM, 2007) é intimamente envolvido com empresas nos níveis regional, nacional e internacional e através de setores. Isto garante seu foco em encontrar soluções práticas para problemas industriais e educar pessoas com a expertise que as empresas necessitam para se manterem competitivas num mercado cada vez mais global. Entre seus 
diversos programas de pesquisa estão vários sobre importância da integração entre design industrial e engenharia no processo de desenvolvimento de produtos. Entre eles, o Programa "Boas Práticas" de Design - Integração entre Engenharia e Design Industrial, com os objetivos de especificar os elementos atuais para uma boa prática de design; criar e validar um processo genérico para a criação de novos produtos integrando planejamento de produto, engenharia e design industrial; identificar as barreiras para a adoção das "Boas Práticas" de design em pequenas e médias empresas.

\subsubsection{Princípios orientadores do bom (processo de) design}

Segundo o IfM (2007), seja qual for a definição do "bom design”, é reconhecido que os produtos bem projetados são essenciais ao sucesso dos negócios. As empresas mais bem sucedidas reconhecem a importância de uma abordagem de design holística, balanceando funcionalidade, performance, produção, estética e ergonomia. É possível projetar um produto de sucesso uma vez contando com a boa sorte, bom timing ou até mesmo trabalho duro. Entretanto, projetar produtos inovadores e vencedores uma vez após outra requer uma abordagem mais confiável e estruturada. Em muitas empresas, o "bom processo de design" é normalmente subaproveitado ou marginalizado, com atenção insuficiente dada à estética, ergonomia ou projeto para manufatura. O projeto estético [aesthetic design; appearance design] é realizado por engenheiros não treinados; designers industriais são empregados muito tarde para fazer a diferença ou os produtos são projetados de forma muito custosa para produzir.

Para tirar vantagem do "bom processo de design", o IfM construiu a seguinte coleção de princípios orientadores: 
- Um processo efetivo para Desenvolvimento de Novos Produtos (DNP): deve prover balanço entre oferecer estrutura de gerenciamento e, ao mesmo tempo, não limitar a criatividade. Desta forma, deve existir um apropriado grau de estruturação e controle para assegurar a repetibilidade do sucesso. Um bom processo facilita e maximiza o trabalho em grupo, encoraja fortemente a comunicação e oferece controle gerencial sem burocracia desnecessária. Boas empresas nunca se acomodam nas suas vitórias e buscam melhorar o processo em cada projeto.

- Escolher os projetos adequados para o investimento de recursos valiosos: uma estratégia de produto efetiva, relacionada com a estratégia geral dos negócios, é crucial para a seleção dos projetos certos.

- Integração precoce de designers especialistas no time principal: não é realista ter todas as habilidades necessárias disponíveis numa empresa. Um projeto pode demandar um expert com habilidades em fatores humanos, análise estilística ou design de interfaces para software. Um time pode precisar de informações de uma disciplina científica específica como ótica ou robótica. Times sólidos reconhecem suas fraquezas e compreendem quanto apoio externo é necessário.

- Sólidas parcerias em design para preencher lacunas de competências e habilidades: especialistas externos deveriam ser vistos como uma parte central do time de design, muitas vezes um ingrediente crítico para o sucesso.

- Uma “visão” de design compartilhada baseada numa clara compreensão do mercado: possuir uma visão compartilhada do produto a ser projetado, aproximando as perspectivas do marketing, design industrial, produção e engenharia é essencial. Esta visão deveria ser baseada numa compreensão clara do mercado, como este é segmentado e como a 
oportunidade será abordada. Onde possível, esta visão deveria ser comunicada simplesmente por uma única e compartilhada especificação de produto.

- Mantendo a integridade da visão de design, da idéia até a produção: compartilhar a visão no âmbito exterior do produto não é o suficiente. O time deveria se esforçar para manter esta visão através do projeto, da idéia até a produção.

- Envolvimento do usuário e consumidor através do processo de design: um dos mais importantes ingredientes do sucesso é o envolvimento de usuários e consumidores através do processo de design. Usuários podem ajudar a gerar insight valiosos em necessidades e desejos futuros e são a fonte única mais valiosa de informação durante a definição do produto. $\mathrm{O}$ envolvimento do usuário durante a seleção de conceitos pode ajudar a reduzir a subjetividade na tomada de decisão. Finalmente, usuários deveriam ser envolvidos em testes de marketing e análises pós-lançamento.

- Encorajamento de uma cultura criativa e busca divergente por idéias: muitas empresas esperam desenvolver novos produtos criativos e inovadores sem prover um ambiente de apoio apropriado. Um elemento-chave de equipes de design é a habilidade de ser divergente na busca de soluções para problemas e uma cultura que apóie a brincadeira e criatividade.

- Prototipagem precoce e frequente: o design de produto é [um processo] reconhecido como tendo riscos inerentes, com uma combinação de riscos de mercado, negócios e técnicos. Prototipagem, construção de modelos, simulação, teste de conceitos e avaliações são geralmente um meio rápido, barato e efetivo de explorar e reduzir estes riscos. Em muitas empresas, o desenvolvimento de protótipos rápidos e relativamente baratos são altamente subutilizados. 
- Consideração igualitária de atributos tangíveis e intangíveis de produtos: em empresas orientadas tecnicamente, as equipes de design tendem a focar na performance [técnica] e funcionalidade [ex.: funções técnico-mecânicas] - os atributos de produto tangíveis - aqueles que podem ser quantificados e mensurados. Equipes deste tipo geralmente prestam pouca atenção para atributos "intangíveis", como, por exemplo, como e onde o produto será utilizado, quem será o usuário, como se parecerá e como será sentido. Estas qualidades intangíveis tendem a ser subjetivas, difíceis de especificar e mensurar, mas são críticas para o projeto de produtos que sejam úteis, utilizáveis, desejáveis, produzíveis e lucrativos. Na verdade, são geralmente estas qualidades intangíveis que conduzem a diferenciação do produto.

- Considerações up front de implicações downstream das decisões de design: garantir que as diretrizes do projeto para produção sejam consideradas tão cedo quanto possível no processo de design. Ainda, outras questões downstream deveriam ser consideradas cedo, incluindo distribuição, ponto de venda, transporte, utilização e descarte final.

- Minimizar a complexidade da empresa e maximizar a variedade de consumidores: produtos são geralmente projetados um de cada vez. Cada produto é diferente e tem diferentes conjuntos de peças, montagens e processos, em comparação aos similares. Equipes de design sólidas consideram questões de modularidade cedo no processo de design e, onde possível, desenvolvem plataformas base de tecnologia que podem ser utilizadas em muitos produtos, atingindo diferentes mercados.

\subsection{CONJUNTO DE "BOAS PRÁTICAS"}

É possível, a partir dos exemplos analisados, propor um conjunto de "Boas Práticas" para aplicação no PDP, que teoricamente otimiza a integração entre design e engenharia. 
Foram privilegiadas, desde a busca inicial bem como no processo de análise, aquelas mais relacionadas com as atividades que acontecem na fase de desenvolvimento do projeto propriamente dito, desconsiderando as mais relacionadas com as atividades que ocorrem em fases anteriores ou posteriores ao desenvolvimento em si, bem como as atividades mais relacionadas com a gestão do processo. Esta decisão foi tomada para melhor atender aos objetivos deste trabalho e buscar a essência destas "Boas Práticas" que podem ser aplicadas em pequenas empresas, considerando que originalmente são oriundas de grandes empresas (com exceção das provindas do grupo IFM), e deverão ser adaptadas para aplicação nas empresas de menor porte.

O Quadro 3.1 articula o conjunto, que foi agrupado de acordo com a similaridade, resultando em um conjunto de "Boas Práticas", sendo uma primária e 3 secundárias, mas não menos importantes, que visam maximizar a implementação da primeira. 
Quadro 3.1 - Proposta de Conjunto de "Boas Práticas"

\begin{tabular}{|c|c|c|c|c|c|c|}
\hline IFM & IDEO & APPLE & PHILIPS & MIT & \multicolumn{2}{|c|}{$\begin{array}{l}\text { “BOAS PRÁTICAS" } \\
\text { PROPOSTAS }\end{array}$} \\
\hline $\begin{array}{l}\text { - Integração } \\
\text { precoce de } \\
\text { designers } \\
\text { especialistas no } \\
\text { time principal } \\
\text { - Sólidas } \\
\text { parcerias em } \\
\text { design para } \\
\text { preencher lacunas } \\
\text { de competências e } \\
\text { habilidades } \\
\end{array}$ & - Hot Teams & $\begin{array}{l}\text { - O design é } \\
\text { envolvido desde o } \\
\text { início }\end{array}$ & $\begin{array}{l}\text { - Envolvimento do } \\
\text { design industrial } \\
\text { desde o início do } \\
\text { processo }\end{array}$ & $\begin{array}{l}\text { - Integração do } \\
\text { design e da } \\
\text { engenharia num } \\
\text { processo unificado } \\
\text { (Wallace e Jakiela; } \\
\text { Smyth e Wallace) } \\
\text { - Envolvimento do } \\
\text { designer industrial } \\
\text { desde o início do } \\
\text { processo (Maeda) }\end{array}$ & $\begin{array}{l}\text { Integração precoce } \\
\text { do design industrial } \\
\text { ao PDP }\end{array}$ & $\frac{\sqrt{2}}{2}$ \\
\hline $\begin{array}{l}\text { - Mantendo a } \\
\text { integridade da } \\
\text { visão de design, } \\
\text { da idéia até a } \\
\text { produção } \\
\text { - Consideração } \\
\text { igualitária de } \\
\text { atributos } \\
\text { tangíveis e } \\
\text { intangíveis de } \\
\text { produtos } \\
\text { - Envolvimento } \\
\text { do usuário e } \\
\text { consumidor } \\
\text { através do } \\
\text { processo de } \\
\text { design }\end{array}$ & $\begin{array}{l}\text { - User-centred } \\
\text { design é a } \\
\text { tônica }\end{array}$ & $\begin{array}{l}\text { - O produto é } \\
\text { desenvolvido de } \\
\text { forma a tender a } \\
\text { performance } \\
\text { técnica e de } \\
\text { interface (A } \\
\text { experiência é o } \\
\text { produto; a filiação } \\
\text { de grupo é a } \\
\text { tônica) } \\
\text { - As diretrizes de } \\
\text { design industrial } \\
\text { são mantidas ao } \\
\text { longo do projeto } \\
\text { (A engenharia } \\
\text { ajuda o design, e } \\
\text { não o contrário) }\end{array}$ & $\begin{array}{l}\text { - Atendimento da } \\
\text { performance de } \\
\text { interface é } \\
\text { prioritário } \\
\text { - Foco no design } \\
\text { industrial, com suas } \\
\text { diretrizes sendo } \\
\text { mantidas ao longo } \\
\text { do projeto } \\
\text { - Projetar produtos } \\
\text { que "fazem sentido" } \\
\text { para as pessoas e } \\
\text { são simples }\end{array}$ & $\begin{array}{l}\text { - Conciliar bom } \\
\text { design centrado no } \\
\text { usuário com } \\
\text { princípios de } \\
\text { engenharia (Mech-E) } \\
\text { - Produtos de } \\
\text { consumo de sucesso } \\
\text { requerem as } \\
\text { habilidades tanto do } \\
\text { designer quanto do } \\
\text { engenheiro (Wallace } \\
\text { e Jakiela; Smyth e } \\
\text { Wallace) } \\
\text { - O projeto de } \\
\text { produtos deve ser } \\
\text { orientado ao usuário } \\
\text { (Maeda) } \\
\text { - Consideração } \\
\text { igualitária das } \\
\text { diretrizes de design } \\
\text { industrial (Maeda) }\end{array}$ & $\begin{array}{l}\text { As diretrizes de } \\
\text { design industrial } \\
\text { (performance de } \\
\text { interface; user- } \\
\text { centred design) são } \\
\text { consideradas no } \\
\text { mesmo nível das } \\
\text { diretrizes de } \\
\text { engenharia } \\
\text { (performance } \\
\text { técnica) }\end{array}$ & \multirow{3}{*}{$\sum_{\substack{\pi \\
2}}^{\infty}$} \\
\hline $\begin{array}{l}\text { - Prototipagem } \\
\text { precoce e } \\
\text { freqüente }\end{array}$ & $\begin{array}{l}\text { - Prototipagem } \\
\text { em todas as } \\
\text { fases do } \\
\text { processo }\end{array}$ & & & $\begin{array}{l}\text { - Prototipagem } \\
\text { precoce e frequente } \\
\text { (Mech-E) }\end{array}$ & $\begin{array}{l}\text { Prototipagem } \\
\text { precoce e freqüente }\end{array}$ & \\
\hline $\begin{array}{l}\text { - Encorajamento } \\
\text { de uma cultura } \\
\text { criativa e busca } \\
\text { divergente por } \\
\text { idéias } \\
\text { - Uma "visão" de } \\
\text { design } \\
\text { compartilhada } \\
\text { baseada numa } \\
\text { clara } \\
\text { compreensão do } \\
\text { Mercado }\end{array}$ & $\begin{array}{l}\text { - Hot Teams } \\
- \\
\text { Brainstorming } \\
\text { - Investigação } \\
\text { coletiva no } \\
\text { front }\end{array}$ & $\begin{array}{l}\text { - Não se pode } \\
\text { agradar a todos } \\
(\ldots) \text { pesquisas de } \\
\text { marketing são um } \\
\text { problema, pois as } \\
\text { pessoas não sabem } \\
\text { o que querem }\end{array}$ & $\begin{array}{l}\text { - Time } \\
\text { multidisciplinar, } \\
\text { inclusive com áreas } \\
\text { normalmente não } \\
\text { ligadas diretamente } \\
\text { ao projeto de } \\
\text { produtos }\end{array}$ & $\begin{array}{l}\text { - Brainstorming } \\
\text { multidisciplinar } \\
\text { (Mech-E) } \\
\text { - Conciliar lados } \\
\text { direito (criatividade) } \\
\text { e lado esquerdo } \\
\text { (analítico) do } \\
\text { cérebro (Mech-E) }\end{array}$ & $\begin{array}{l}\text { Participação de toda } \\
\text { a equipe em } \\
\text { brainstormings e na } \\
\text { aplicação de técnicas } \\
\text { investigativas no } \\
\text { front }\end{array}$ & \\
\hline
\end{tabular}




\section{APRESENTAÇÃO E ANÁLISE DOS RESULTADOS}

$\mathrm{O}$ conjunto de atividades realizadas foi amplo, acontecendo paralelamente às atividades dos Núcleos de Design e Engenharia do Parqtec que, ao longo de 18 meses, conduziu atividades relacionadas a convênios com agências de fomento com o objetivo de aumentar a competitividade de empresas de pequeno porte através do design industrial.

Estas empresas participaram de um processo que consistiu de: (i) palestra de conscientização sobre a importância do design industrial na atualidade e esclarecimentos de aspectos técnicos, econômicos e práticos relacionados; (ii) entrevista com duração de aproximadamente uma hora, com suporte de questionário com questões abertas e fechadas; (iii) avaliação da entrevista e formatação de relatório de diagnóstico, consistindo da situação da empresa e dos seus produtos, a visão do empresário a respeito dos produtos, forma e intensidade do conhecimento, utilização do design no PDP, etc; (iv) recomendações de ações de curto e médio prazo; (v) realização de oficinas, palestras e eventos; (vi) desenvolvimento de projetos de produto, design gráfico, design de embalagens, design de interfaces, projetos mecânicos, simulações, prototipagem etc.

Destas atividades, foram analisados para este trabalho: documentação das entrevistas e visitas a aproximadamente 180 empresas; entrevistas com designers industriais e engenheiros que participaram do processo e desenvolveram produtos diversos para estas empresas; entrevistas com empresários, engenheiros e outros profissionais das equipes das empresas; acompanhamento e participação das interações entre empresas, designers, engenheiros, fornecedores, técnicos de agências de fomento, gerentes de incubadoras e outros participantes do processo; acompanhamento e participação no processo de desenvolvimento de vinte e oito produtos de diversas naturezas (entre outros trabalhos de outras áreas do design e engenharia), dez dos quais aqui apresentados como estudos de caso. 


\subsection{EMPRESAS DE PEQUENO PORTE EM RELAÇÃO AO MODELO DE "MATURIDADE DE DESIGN"}

A amostra de empresas utilizada para a classificação no modelo de "Maturidade de Design" consistiu de 180 empresas, pertencentes majoritariamente ao setor industrial em diversos segmentos $^{52}$ (máquinas e equipamentos, eletro-eletrônicos, aeronáutica, cerâmica de revestimento, cerâmica "artística", produtos têxteis, jóias folheadas, produtos agrícolas, software, entre outros) e espalhadas geograficamente em cerca de 33 cidades do Estado de São Paulo. Aproximadamente $86 \%$ do total das empresas pesquisadas é de pequeno porte e $14 \%$ é de médio porte ${ }^{53}$. Cerca de $50 \%$ se encontrava em de incubadoras de empresas, possuindo porte pequeno e com tempo de vida de um a cinco anos.

A tabela 4.1 demonstra a distribuição destas empresas no modelo de "Maturidade de Design”, conforme classificadas pelo pesquisador a partir das informações coletadas. Buscouse observar aspectos como a visão de design da empresa, freqüência e utilização anterior de design, papel do design no processo, composição da equipe de desenvolvimento de produtos da empresa, estágio em que a empresa busca o design, entre outros, de forma a classificar as empresas a partir das características específicas de cada nível do modelo - ver Quadro 1.1. na Seção 1.2.3.2. Especial atenção foi dada à comparação das informações fornecidas pelo entrevistado com a realidade da empresa, uma vez que houve a oportunidade de visitar as suas instalações e houve acesso aos seus produtos, material de comunicação e equipe de desenvolvimento.

\footnotetext{
52 A grande maioria das empresas da amostra estava desenvolvendo produtos para fabricação própria e/ou terceirização da fabricação de componentes e posterior montagem final.

${ }^{53}$ De acordo com a metodologia de classificação adotada pelo Sebrae, através do número de funcionários, apresentada na Seção 1.2.3.2.
} 
Tabela 4.1 - Distribuição da amostra de empresas no modelo de "Maturidade de Design"

\begin{tabular}{|c|c|c|c|c|c|c|}
\hline & Nível I & Nível II & Nível III & Nível IV & & \\
\hline & $\begin{array}{c}\text { Design } \\
\text { Silencioso }\end{array}$ & $\begin{array}{l}\text { Maquiagem de } \\
\text { Produto }\end{array}$ & $\begin{array}{c}\text { Inovação } \\
\text { Orientada pelo } \\
\text { Design }\end{array}$ & $\begin{array}{c}\text { Design } \\
\text { Estratégico }\end{array}$ & & \\
\hline \multirow{2}{*}{$\begin{array}{c}\text { AMOSTRA } \\
\text { GERAL }\end{array}$} & $54.44 \%$ & $32.78 \%$ & $11.67 \%$ & $1.11 \%$ & $100.00 \%$ & $\%$ \\
\hline & 98 & 59 & 21 & 2 & 180 & $\mathrm{n}^{\circ}$ emp. \\
\hline \multirow[t]{2}{*}{ Pequeno Porte } & $56.13 \%$ & $32.26 \%$ & $10.97 \%$ & $0.65 \%$ & $86.11 \%$ & $\begin{array}{c}\% \mathrm{da} \\
\text { Amostra }\end{array}$ \\
\hline & 87 & 50 & 17 & 1 & 155 & $\mathrm{n}^{\circ}$ emp. \\
\hline \multirow[t]{2}{*}{ Médio Porte } & $44.00 \%$ & $36.00 \%$ & $16.00 \%$ & $4.00 \%$ & $13.89 \%$ & $\begin{array}{c}\% \text { da } \\
\text { Amostra }\end{array}$ \\
\hline & 11 & 9 & 4 & 1 & 25 & $\mathrm{n}^{\circ}$ emp. \\
\hline \multirow[t]{2}{*}{ Incubadoras } & $61.36 \%$ & $30.68 \%$ & $6.82 \%$ & $1.14 \%$ & $48.89 \%$ & $\begin{array}{c}\% \text { da } \\
\text { Amostra }\end{array}$ \\
\hline & 54 & 27 & 6 & 1 & 88 & $\mathrm{n}^{\circ}$ emp. \\
\hline \multirow{2}{*}{ Base Tecnológica } & $45.00 \%$ & $35.00 \%$ & $17.50 \%$ & $2.50 \%$ & $22.22 \%$ & $\begin{array}{c}\% \text { da } \\
\text { Amostra }\end{array}$ \\
\hline & 18 & 14 & 7 & 1 & 40 & $\mathrm{n}^{\circ}$ emp. \\
\hline
\end{tabular}

Do ponto de vista do modelo de "Maturidade de Design", a situação encontrada demonstra que a maioria das empresas da amostra possui características do Nível I do modelo, denominado "Design Silencioso", onde o projeto de produtos é feito por pessoas não especialistas em design industrial, normalmente o sócio-proprietário da empresa, a esposa, um funcionário mais antigo com domínio da "arte produtiva", alguém considerado "criativo" ou com "talento". Uma outra parte significativa, quando busca o design, o faz normalmente por pressão da concorrência ou por "modismo", entendendo o design como algo a ser adicionado no final do processo, para intervir esteticamente - a visão conhecida como "Maquiagem de Produto" (Nível II). É relevante, e preocupante, que aproximadamente $87 \%$ das empresas da amostra estão concentradas nos dois primeiros níveis, onde o design é negligenciado, realizado por não-profissionais ou aplicado superficialmente. Uma parte bem menos significativa traz o design para o início do projeto, desde a compreensão da idéia, envolvendoo em todas as fases (Nível III). O "Design Estratégico" (Nível IV) foi praticamente desprezível na amostra. 
De uma forma geral, percebeu-se certa correlação entre o tempo de vida/“tamanho" das empresas e uma tendência a utilizar o design de forma mais precoce, como pode ser observado nas diferenças de distribuição entre empresas de pequeno porte, médio porte e empresas residentes em incubadoras, normalmente start-ups com pouco tempo de vida. As empresas com mais tempo de existência e um pouco maiores parecem valorizar e utilizar o design de forma ligeiramente mais adequada do que empresas em início de atividades ou muito pequenas.

As empresas de base tecnológica apresentaram uma proporção maior de empresas nos níveis mais altos do modelo, em relação à distribuição das empresas em geral. Pelo que pode ser percebido, o fato talvez possa ser atribuído à melhor formação dos sócios-proprietários, maior acesso à informação, concorrência internacional e produtos de maior complexidade.

Devido aos limites inerentes à forma como os dados foram coletados e tratados e os objetivos desta pesquisa, esta análise pode apenas indicar tendências e apontar correlações iniciais, que possam servir de indicadores para pesquisas futuras desenhadas especificamente para captar estas correlações.

A Tabela 4.2 mostra a distribuição da amostra em comparação com estudos similares baseados em modelos do tipo "Escada do Design" (NAEH \& DDC, 2003; GMBH, 2006; SWEDISH INDUSTRIAL DESIGN FOUNDATION, SWEDISH ENGINEERING INDUSTRIES, 2004). Os estudos utilizaram amostragem de diferentes tamanhos e composição, de acordo com a realidade do país e os objetivos específicos, bem como em outros aspectos metodológicos. A comparação visa contextualizar preliminarmente a amostra deste estudo. 
Tabela 4.2 - Comparativo da distribuição da amostra com estudos similiares ${ }^{54}$

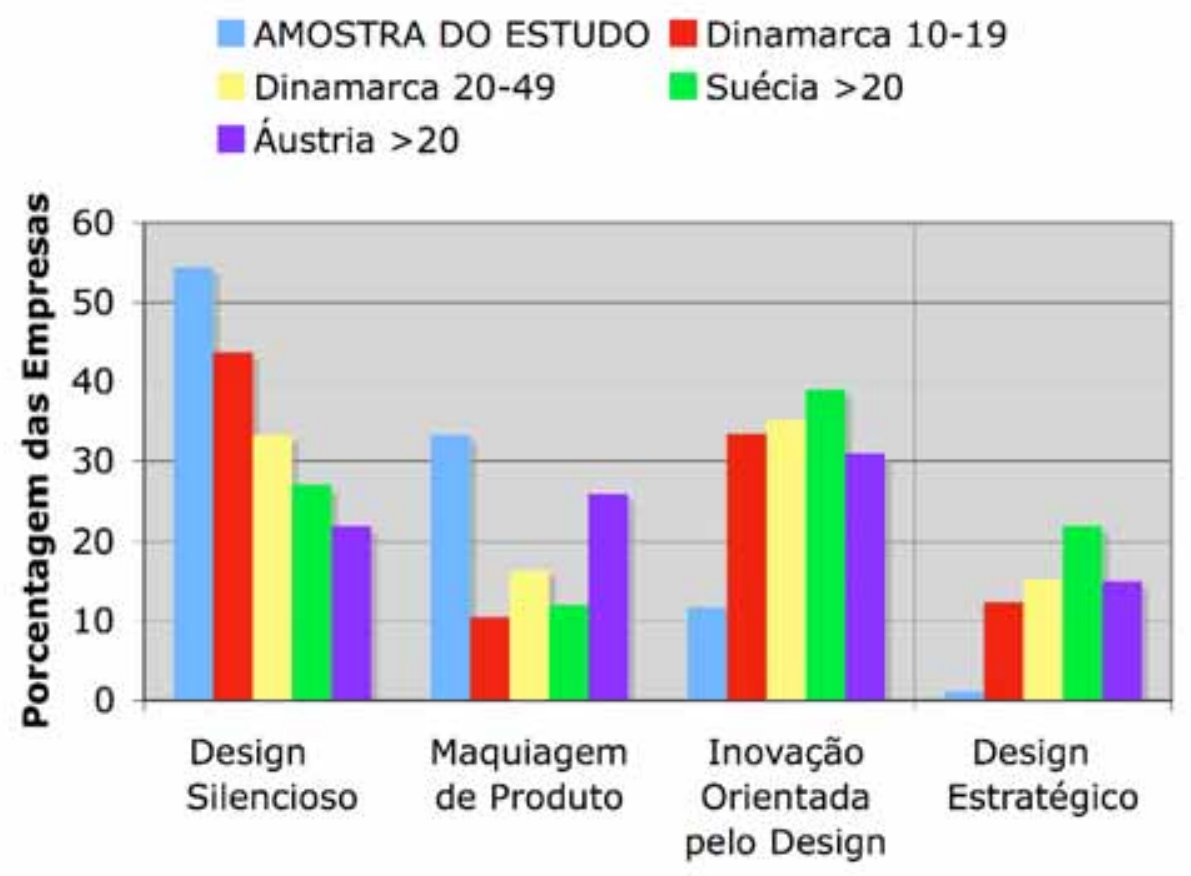

Níveis do Modelo de Maturidade

É evidente a discrepância da distribuição da amostra em relação aos outros estudos, especialmente a grande concentração de empresas nos dois primeiros níveis do modelo Design Silencioso e Maquiagem de Produto - o baixíssimo número de empresas no terceiro nível - Inovação Orientada pelo Design - e o número de empresas praticamente nulo no último nível - Design Estratégico.

A tendência geral nos três estudos utilizados para comparação é que aproximadamente metade das empresas estão distribuídas nos dois primeiros níveis e o restante nos dois últimos. Interessante notar que a concentração é maior, nos três estudos (menos, mas ainda assim, maior no estudo austríaco), no terceiro nível do que no segundo. Isto parece indicar que, uma vez conscientizadas adequadamente sobre a importância do design, as empresas

\footnotetext{
${ }^{54}$ Os números à frente do nome do país indicam o número de funcionários das empresas pesquisadas, sendo: (i) empresas da Dinamarca que possuem de 10 a 19 funcionários; (ii) empresas da Dinamarca que possuem de 29 a 49 funcionários; (iii) empresas da Suécia que possuem mais de 20 funcionários; (iv) empresas da Áustris que possuem mais de 20 funcionários.
} 
tendem a utilizá-lo mais profundamente, ao invés de superficialmente, como acontece no nível II. Considerando que estes países tem agências bem financiadas e relativamente antigas dedicadas à promoção do design, talvez isto possa indicar que o trabalho tenha surtido efeito.

$\mathrm{Na}$ amostra deste estudo, por sua vez, mais de $80 \%$ das empresas estão nos dois primeiros níveis e o nível II é maior do que o nível III, o que parece indicar que existe um problema de falta de compreensão do papel do design, apontando, inclusive nos três estudos utilizados para comparação, como o principal para a utilização do design problema entre as empresas de menor porte.

Alguns fatores podem ter contribuído para a discrepância encontrada:

- na amostra deste estudo foi utilizado um número relevante de empresas com menos de cinco anos e muito pequenas, com poucos funcionários (como é o caso das instaladas em incubadoras), e nos estudos utilizados para comparação, dois incluíram empresas de grande porte na amostra (as pesquisas sueca e austríaca consideraram empresas acima de 20 funcionários) e um estudo (dinamarquês) considerou empresas acima de 10 funcionários somado;

- os três estudos de comparação foram realizados em países europeus, com tradição em design, visão integradora do design, centros de pesquisa de ponta, agências de fomento ativas e bem financiadas, interesse governamental, empresas inovadoras e empresariado com perfil mais propício ao design, concorrência baseada no design, entre outras características. A amostra foi realizada em um país em desenvolvimento, com fraca tradição em design, baixa inovação, competição baseada na cópia, agências promotoras do design mal financiadas e recentes, governo que tem prioridades mais primárias do que o design, empresas muito pequenas e com empresariado pouco permeável ao design, além de outras características. 
Este fatores talvez possam explicar a discrepância observada e possíveis distorções nos resultados. Por outro lado, era esperado, pela revisão da literatura e pela prática, que as empresas de pequeno porte apresentassem baixa intensidade de utilização de design, catalisadas pela condições brasileiras. Ainda, conforme a revisão biliográfica, as empresas de pequeno porte no Brasil tendem a ter poucos funcionários - menos de 10 (SEBRAE, 2006b), e o fato da amostra ser predominantemente de empresas muito pequenas e com pouco funcionários pode ser um ponto forte, e não fraco, da pesquisa realizada.

Assim sendo, mesmo com as distorções oriundas do método adotado, é possível afirmar que as empresas da amostra tendem, predominantemente, a não integrar o design precocemente nas suas atividades, e, quando o fazem, é de forma superficial, como maquiagem de produto.

\subsubsection{Observações qualitativas em relação à "Maturidade de Design" da amostra}

A análise feita a seguir, embora generalista e qualitativa, é baseada em tendências e similaridades observadas de forma muito clara na amostragem de empresas e acredita-se que possa ser útil, pelos indícios que oferece, ao menos como base para orientação de estudos futuros, mais específicos e quantitativos. Certamente existem muitos pontos para tal.

A análise permite observar que os empresários de empresas de pequeno porte se encaixam no perfil indicado correntemente em publicações, congressos e seminários relacionados aos estudos dos empreendimentos brasileiros: suas atividades baseiam-se essencialmente na prática, carecendo de reflexão e da utilização de referenciais teóricos que possam coletar dados, realizar análises e modificar a própria prática. Em muitos casos, observou-se posição confusa no fornecimento de informações relacionadas à empresa, tais como faturamento anual, número de peças produzida/mês, estrutura de componentes do 
produto, custo do produto, estratégia de precificação e, principalmente, informações relacionadas ao seu posicionamento e estratégia de abordagem do mercado - na verdade, em muitos momentos ficou claro que este posicionamento e estratégia inexistem de forma clara e organizada.

Os responsáveis pelo desenvolvimento dos produtos são, na maioria dos casos, os próprios proprietários, parentes, amigos, modelistas, desenhistas técnicos, engenheiros e outros. Muito raramente um profissional com formação em design industrial. Na maioria das vezes, os aspectos de performance de interface são simplesmente ignorados ou realizados sem o arcabouço técnico adequado (é comum a crença que apenas o bom senso é suficiente). Quando questionados sobre a formação acadêmica dos responsáveis pelo desenvolvimento de produtos, muitos ignoravam esta informação e, aqueles que informaram, alegavam "formação prática".

As referências para os projetos de produtos, pelo que se pode perceber através das respostas, são retiradas de websites de concorrentes, novelas, revistas, feiras, clientes. Não aparentam apresentar uma metodologia organizada para coletar, tratar estas informações e transformá-las em inputs para os projetos, mas realizar uma "cópia com alterações" - nas palavras de alguns empresários. Uma parte expressiva das empresas escolheu a palavra "tendência" como orientadora do desenvolvimento de produto, e, pelo que se pode inferir, tendência significa essencialmente "observar o que os outros fazem e tentar fazer algo parecido", para citar a resposta de um empresário. A atitude reativa é generalizada e praticamente todas as empresas citaram a cópia como um problema, sendo esta uma prática visivelmente comum e praticada de forma indiscriminada.

As empresas carecem de posicionamento claro quanto questionadas sobre sua estratégia de abordagem do mercado. Aparentam desconhecer ou não utilizar técnicas de 
segmentação de mercado para desenvolver produtos que atendam as necessidades e aspirações específicas de grupos - aqui se fala do cliente final, aquele que utilizará o produto.

A visão sobre o que é design industrial, sua prática e aplicações, seus resultados e importância estratégica, é distorcida, pouco profunda, equivocada e até contraditória. Fala-se em design e alega-se considerar importante, mas mais à frente, ao responder outras questões, pode-se perceber que é uma visão distorcida e que mesmo sendo considerado importante, é relegado para segundo plano ou carece de ações que realmente sejam adequadas. Nota-se em uma parcela das empresas, certa consciência da importância do design, entendido essencialmente como styling, ou seja, criação de novas formas para os produtos - leia-se "Maquiagem de Produtos" - visão esta demasiadamente ligada à criatividade pessoal, uma atividade artística, plástica. Observou-se que, em um grande número de casos, o discurso do entrevistado, normalmente o sócio-proprietário de uma pequena empresa, não correspondia com o observado. Os entrevistados tendiam a valorizar o design no discurso mas a realidade apresentava negligência e superficialidade. Este aspecto talvez tenha contribuído para aumentar ainda mais a discrepância da amostra brasileira dos estudos similares, uma vez que nestes estudos a classificação levou em conta, além das informações fornecidas pelas empresas, uma auto-classificação das mesmas nos níveis do modelo. Acredita-se que, se fosse solicitado às empresas da amostra para se auto-classificarem, a distribuição se deslocaria aos níveis mais altos.

\subsection{ESTUDOS DE CASO}

Um importante resultado deste trabalho, pois ofereceu uma visão mais detalhada e aprofundada, foi a observação dos produtos e do processo de desenvolvimento dos mesmos em pequenas empresas, utilizando-se como evidência casos reais de empresas de base 
tecnológica (ver Quadro 4.1). De acordo com o método proposto (ver seções 1.2.3 a 1.2.4), foram selecionadas da amostra empresas de base tecnológica (10) classificadas nos Níveis II e III do modelo de "Maturidade de Design" (ver Quadro 4.2), para que se levasse a cabo desenvolvimento de produto balizado pelas "Boas Práticas" propostas (algumas imagens ilustrativas do desenvolvimento dos produtos podem ser observadas no Apêndice A).

Os produtos foram desenvolvidos por equipes multidisciplinares, com diferentes composições e tamanhos, sempre constituídas por designers industriais do Núcleo de Design do Parqtec (em alguns casos, também engenheiros desta instituição) e engenheiros (de diversas áreas) das empresas. Os desenvolvimentos tiveram períodos diferentes, com grande variação (de dois a dezoito meses), e também chegaram a estágios diferentes ao tempo da apresentação destes resultados (alguns estavam entrando no mercado, outros em fase de validação do protótipo). Acredita-se que estas características não se constituíram em prejuízo para a análise, pois se trata de observar potencialmente a chance de sucesso no mercado, com o objetivo de analisar a adoção e manifestação de "Boas Práticas" que reconhecidamente aumentam a chance de sucesso, de acordo com o levantado no referencial teórico.

O processo de desenvolvimento de produtos foi orientado pela equipe do Parqtec, coordenada pelo presente pesquisador, com a tônica de integração do design industrial a engenharia. Para isso, foram utilizadas as "Boas Práticas" propostas, aplicadas e adaptadas para se adequar da forma mais eficiente à realidade encontrada, com objetivo duplo: ao mesmo tempo em que permite observar se as pequenas empresas brasileiras aplicam estas "Boas Práticas" - especialmente a primária - que podem conduzir a uma melhor integração e produtos mais competitivos, permite também observar quais os benefícios e barreiras para a sua aplicação. 
Quadro 4.1 - Características de entorno dos projetos de produto selecionados

\begin{tabular}{|c|c|c|c|c|c|c|c|c|}
\hline$\underset{\stackrel{O}{E}}{\stackrel{0}{0}}$ & 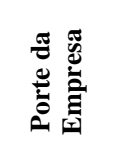 & 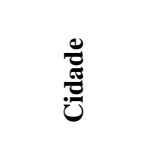 & 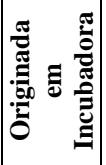 & 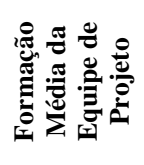 & 紊: & ڤே̆ & 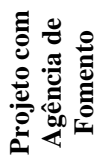 & 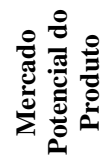 \\
\hline 1 & Pequena & São Carlos & Sim & $\begin{array}{c}\text { Pós- } \\
\text { graduação }\end{array}$ & $\begin{array}{c}\text { Engenharia } \\
\text { Mecatrônica e } \\
\text { de Computação }\end{array}$ & Robótica & Sim & $\begin{array}{c}\text { América } \\
\text { Latina }\end{array}$ \\
\hline 2 & Pequena & São Carlos & Sim & $\begin{array}{c}\text { Pós- } \\
\text { Graduação }\end{array}$ & $\begin{array}{c}\text { Engenharia } \\
\text { Mecatrônica e } \\
\text { de Computação }\end{array}$ & Robótica & Sim & $\begin{array}{c}\text { América } \\
\text { Latina }\end{array}$ \\
\hline 3 & Pequena & São Carlos & Sim & Graduação & $\begin{array}{l}\text { Física/Engenhar } \\
\text { ia de Materiais }\end{array}$ & $\begin{array}{c}\text { Cerâmicas } \\
\text { Piezo-Elétricas }\end{array}$ & - & Nacional \\
\hline 4 & Pequena & $\begin{array}{l}\text { S. J. dos } \\
\text { Campos }\end{array}$ & Sim & Graduação & $\begin{array}{c}\text { Engenharia/Me } \\
\text { dicina }\end{array}$ & $\begin{array}{c}\text { Equipamentos } \\
\text { Médico- } \\
\text { Hospitalares }\end{array}$ & Sim & Nacional \\
\hline 5 & Pequena & São Carlos & Sim & $\begin{array}{c}\text { Pós- } \\
\text { graduação }\end{array}$ & $\begin{array}{c}\text { Física Nuclear, } \\
\text { Agronomia, } \\
\text { Engenharia } \\
\text { Mecatrônica } \\
\end{array}$ & $\begin{array}{l}\text { Instrumentação } \\
\text { Agropecuária }\end{array}$ & Sim & Mundial \\
\hline 6 & Pequena & $\begin{array}{c}\text { Araraquara/ } \\
\text { São Carlos }\end{array}$ & Sim & $\begin{array}{c}\text { Pós- } \\
\text { graduação }\end{array}$ & $\begin{array}{l}\text { Química } \\
\text { Molecular }\end{array}$ & Nanotecnologia & Sim & Mundial \\
\hline 7 & Pequena & São Carlos & Sim & $\begin{array}{c}\text { Pós- } \\
\text { graduação }\end{array}$ & $\begin{array}{l}\text { Química } \\
\text { Molecular }\end{array}$ & Biotecnologia & Sim & $\begin{array}{c}\text { América } \\
\text { Latina }\end{array}$ \\
\hline 8 & Pequena & $\begin{array}{c}\text { São José } \\
\text { dos } \\
\text { Campos }\end{array}$ & Sim & Graduação & $\begin{array}{c}\text { Engenharia } \\
\text { Mecânica/Meca } \\
\text { trônica }\end{array}$ & $\begin{array}{c}\text { Som } \\
\text { Automotivo }\end{array}$ & Sim & Mundial \\
\hline 9 & Pequena & Campinas & Sim & Graduação & $\begin{array}{c}\text { Engenharia } \\
\text { Mecânica/Elétri } \\
\text { ca; Ciência da } \\
\text { Computação }\end{array}$ & $\begin{array}{l}\text { Análise de } \\
\text { Imagem }\end{array}$ & Não & $\begin{array}{c}\text { América } \\
\text { Latina }\end{array}$ \\
\hline 10 & Pequena & São Carlos & Sim & $\begin{array}{l}\text { Pós- } \\
\text { graduação }\end{array}$ & $\begin{array}{l}\text { Engenharia } \\
\text { Mecatrônica; } \\
\text { Ciência e } \\
\text { Engenharia da } \\
\text { Computação }\end{array}$ & Robótica & Sim & $\begin{array}{c}\text { América } \\
\text { Latina }\end{array}$ \\
\hline
\end{tabular}

\section{Quadro 4.2 - Seleção de empresas/produtos de base tecnológica na amostra classificada}

\begin{tabular}{|c|c|c|c|}
\hline \multicolumn{2}{|c|}{ Nível II - Maquiagem de Produto } & \multicolumn{2}{|c|}{ Nível III - Inovação Orientada pelo Design } \\
\hline \multicolumn{2}{|c|}{$\begin{array}{l}\text { A empresa procurou os serviços de design industrial para } \\
\text { uma intervenção superficial, normalmente de natureza } \\
\text { estética. }\end{array}$} & \multicolumn{2}{|c|}{$\begin{array}{l}\text { A empresa procurou os serviços de design industrial para } \\
\text { intervenção mais profunda, envolvendo a evolução de } \\
\text { uma idéia ou conceito de produto. }\end{array}$} \\
\hline Empresa/Produto 1 & $\begin{array}{l}\text { Robô para ensino, pesquisa } \\
\text { e entretenimento }\end{array}$ & Empresa/Produto 8* & $\begin{array}{l}\text { Dispositivo automotivo } \\
\text { para transmissão de música } \\
\text { digital sem fio }\end{array}$ \\
\hline Empresa/Produto 2 & Jogo de futebol com robôs & Empresa/Produto 9 & Scanner tridimensional \\
\hline Empresa/Produto 3 & $\begin{array}{l}\text { Equipamento para análise } \\
\text { de transdutores }\end{array}$ & Empresa/Produto 10 & Robô para ensino superior \\
\hline Empresa/Produto 4 & $\begin{array}{l}\text { Equipamento para } \\
\text { contagem e dosagem de } \\
\text { soro }\end{array}$ & & \\
\hline Empresa/Produto 5 & $\begin{array}{l}\text { Equipamento para análise } \\
\text { do solo com fonte atômica }\end{array}$ & & \\
\hline Empresa/Produto 6 & $\begin{array}{l}\text { Equipamento para síntese } \\
\text { de materiais } \\
\text { nanotecnológicos }\end{array}$ & & \\
\hline Empresa/Produto 7 & $\begin{array}{l}\text { Equipamento para Análise } \\
\text { de DNA }\end{array}$ & & \\
\hline
\end{tabular}

* A empresa 8 foi classificada no Nível IV - "Design Estratégico". Na prática, não apresentará diferenças significativas, uma vez que o que está sendo avaliado é a integração precoce do design ao PDP. 


\subsubsection{Aplicação da "Ferramenta de Auditoria do Produto"}

Os produtos foram analisados através da "Ferramenta de Auditoria do Produto" (descrita na seção 1.2.4), conforme resumido abaixo e descrito em detalhes na seção. 1.2.3:

(1) Aplicação nos produtos originais das empresas do Nível II;

(2) Aplicação nos produtos do Nível II após novo desenvolvimento, com a adoção das "Boas Práticas” propostas, com ênfase na integração precoce;

(3) Aplicação nos produtos do Nível III, desenvolvidos com ênfase na integração precoce.

Para a análise da situação de cada dimensão do produto, foi utilizado um fator, obtido a partir da razão entre o valor atribuído pela equipe na avaliação do produto (situação atual) e o valor que representa a importância dada à dimensão pelo usuário (situação desejável). Valores menores que 1 indicam necessidade de melhoria; valores maiores que 1 indicam performance acima da esperada.

\subsubsection{Novo desenvolvimento de produtos para as empresas do Nível II}

Os resultados obtidos com os produtos das empresas classificadas no Nível II do modelo de "Maturidade de Design" demonstram que:

(i) As empresas que compreendem o design industrial como maquiagem de produto, ou seja, apenas como uma intervenção superficial de ordem normalmente estética visual, podem ser deficientes para a competição atual, uma vez aceito que é necessário privilegiar tanto a performance técnica como a performance de interface. Isto é evidenciado pelo baixo desempenho encontrado nos seus produtos originais nas dimensões "Usabilidade" e 
"Desejabilidade", diretamente relacionadas com a participação do design industrial no PDP (ver Tabela 4.3);

(ii) As empresas, originalmente, desenvolveram seus produtos sem a participação de um designer profissional no processo, o que indica que se comportaram como o previsto no Nível I - Design Silencioso - do modelo de "Maturidade de Design". A busca por design ocorreu, provavelmente, porque passaram por um processo de conscientização promovido pelo Parqtec. Desta forma, pode-se inferir que boa parte destas empresas iria ao mercado com os produtos da forma como se encontram, argumento reforçado pelo fato destas empresas possuírem protótipos avançados ou o produto pronto. Tendo em vista que considerar a performance de interface é essencial para competir atualmente, as empresas podem estar desenvolvendo produtos com maior dificuldade em obter sucesso, com problemas de recompra, manutenção, uso, baixo valor agregado e diferenciação etc;

(iii) Os produtos submetidos a um novo processo de desenvolvimento que privilegia a integração do design industrial desde o início estão potencialmente mais preparados para a competição no mercado, o que pode ser observado pela equalização dos resultados para os níveis desejados em cada dimensão, especialmente nas dimensões "Usabilidade" e “Desejabilidade" (ver Tabela 4.4);

(iv) A integração do design industrial no início do processo pode, inclusive, melhorar o desempenho na dimensão "Qualidade de Engenharia", pela utilização de critérios que privilegiam aspectos intangíveis na escolha de materiais, configuração formal e outros aspectos construtivos que conduzem à melhor qualidade percebida, além das qualidades intrínsecas construtivas de performance técnica (ver Tabela 4.4). 
Tabela 4.3 - "Auditoria do Produto" nos produtos das empresas do Nível II - projetos originais; sem integração

\section{Produtos Nivel II - ANTES}

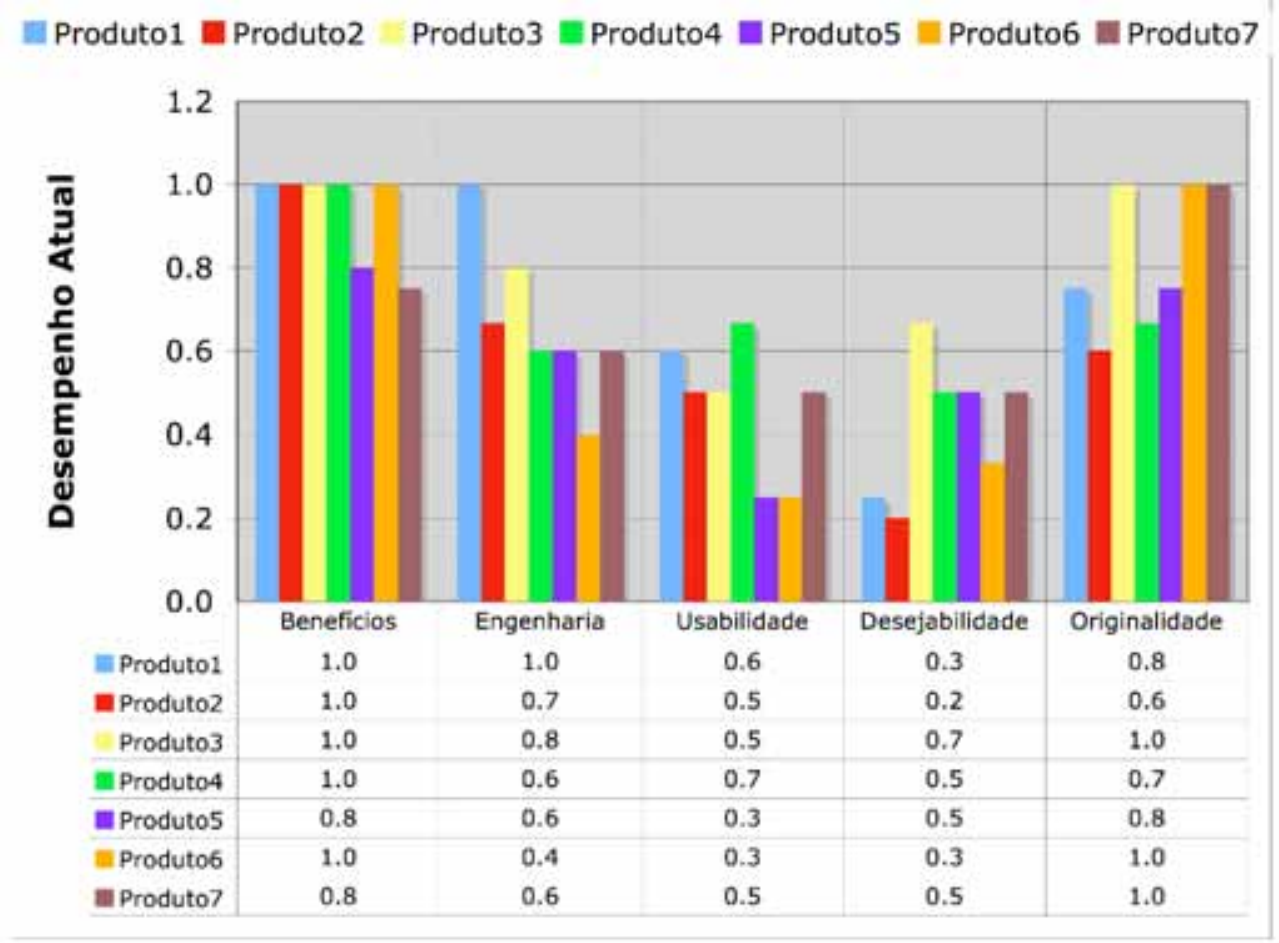

Tabela 4.4 - "Auditoria do Produto" nos produtos das empresas do Nível II após novo PDP com integração precoce do design industrial

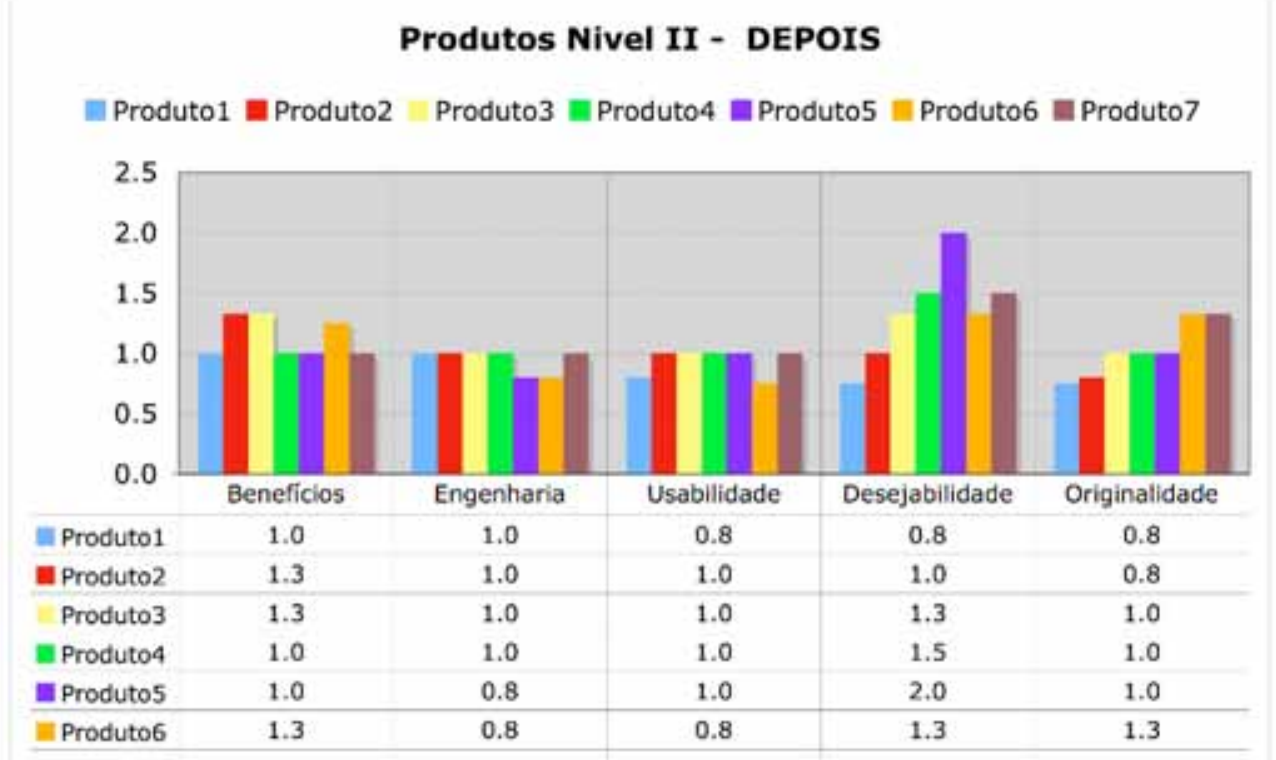




\subsubsection{Desenvolvimento de produtos para as empresas do Nível III}

Os resultados obtidos com os produtos das empresas classificadas no Nível III do modelo de "Maturidade de Design" demonstram que: as empresas que compreendem o design industrial como parte integrante do PDP desde as fases iniciais desenvolvem produtos potencialmente mais preparados à competição no mercado atual, da primeira vez (ver Tabela $4.5)$.

Tabela 4.5 - “Auditoria do Produto” nos produtos das empresas do Nível III - projeto desenvolvidos com integração precoce do design originalmente

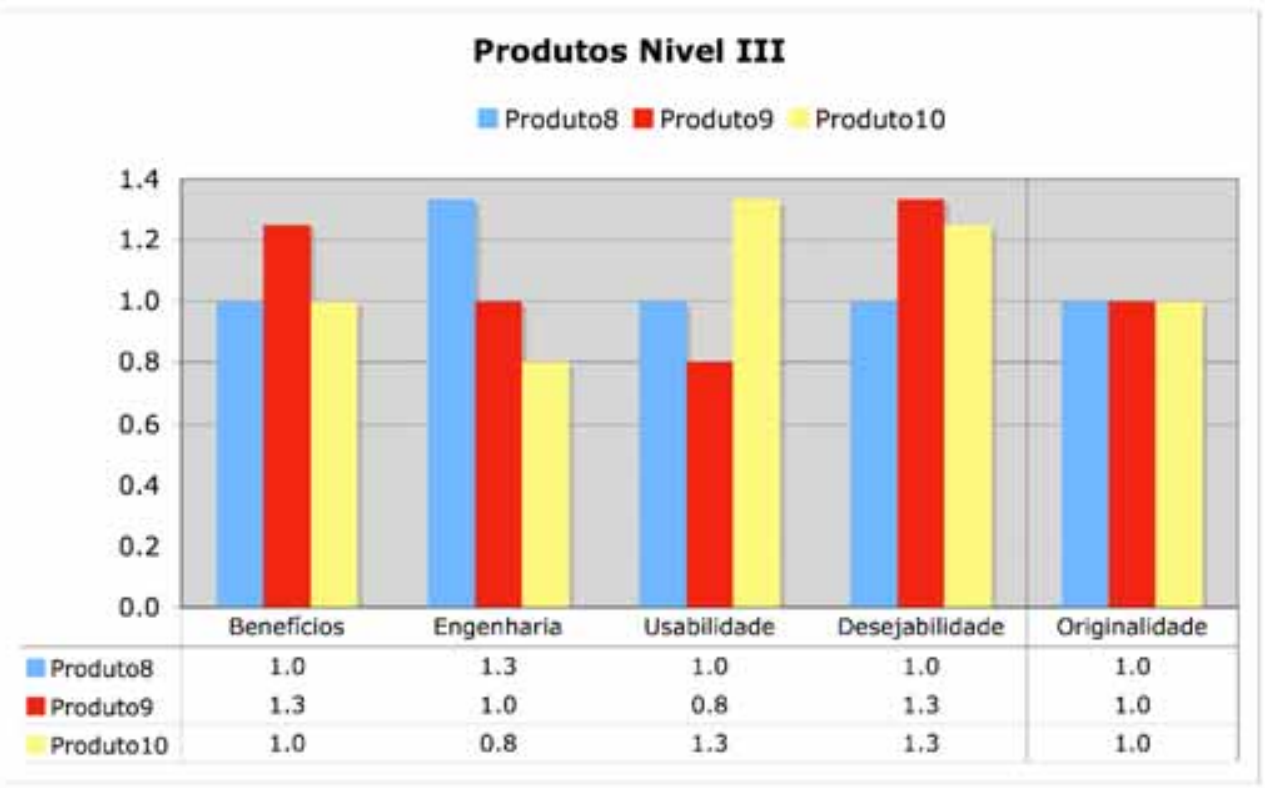

\subsubsection{Considerações qualitativas sobre os estudos de caso}

O acompanhamento do PDP - através da participação efetiva, observação direta e indireta, entrevistas com os participantes, análise documental - permite fazer as seguintes considerações: 
I - Para as Empresas/Produtos do Nível II:

(a) os participantes do PDP nas empresas do Nível II são essencialmente profissionais ligadas às áreas de exatas, especialmente engenheiros (mecânicos, mecatrônicos, computação) ou fazendo papel de engenheiros, com grande dificuldade e até resistência ou preconceito com aquelas dimensões do produto mais intangíveis (ligadas à performance de interface), especialmente aquelas com maior dificuldade de se demonstrar quantitativamente;

(b) o produto é resultado direto das decisões de engenharia e sua inserção no mercado é vista como influenciada exclusivamente pelas características técnicas, isto é, o atendimento eficiente e eficaz de uma necessidade de realizar alguma tarefa técnica;

(c) a utilização do design industrial é algo superficial, buscado após: a comparação do seu produto/protótipo final com similares (principalmente importados); uma tentativa fracassada de colocação preliminar do produto no mercado; o contato com possíveis compradores que indicaram um problema na performance de interface - em todos os casos, é entendida pela empresa como a necessidade de uma modificação apenas cosmética, o que é até natural, pois a empresa não possui nenhum profissional com a formação necessária para uma compreensão mais aprofundada;

(d) como é entendida apenas como cosmética, a alteração se torna algo incômodo, onde se deseja investir pouco tempo e recursos;

(e) pelo mesmo motivo, associado à formação dos profissionais da empresa, existe grande resistência em efetuar as alterações no projeto original para que se atinja adequadamente uma boa performance de interface, tanto pela percepção equivocada que o design industrial é apenas cosmético (mudança de cores, acabamentos superficiais, alterações de posição simples, etc) e, portanto, superficial, rápido e barato, quanto pela posição 
defensiva da equipe original, que enxerga os designers como intrusos e desqualificados para solicitar alterações num projeto robusto que, afinal, nem deveria ser alterado, se não fosse o pedido dos donos da empresa;

(f) as alterações no projeto original dos produtos foram de tal ordem que praticamente se pode considerar como um novo projeto, com todas as implicações que acarretam; em todos os casos, para atingir uma boa performance de interface - o que engloba ergonomia física/cognitiva, usabilidade, aspectos estéticos visuais, sonoros, tácteis, etc - foram necessárias mudanças no projeto mecânico/eletrônico/estrutural original;

(g) mesmo com mudanças significativas, aspectos de DfX ${ }^{55}$, etc não puderam ser aplicados em profundidade, pois muitos recursos haviam sido investidos e a empresa, sendo de pequeno porte, não poderia arcar com os custos de uma reformulação total do conceito; assim sendo, mesmo com uma grande reformulação, foram mantidos aspectos mais críticos e com maior impacto no custo de ferramentaria, moldes, etc;

(h) o novo PDP foi permeado por conflitos entre a equipe interna e a equipe externa de design industrial e engenharia, a despeito da conscientização inicial sobre qual o papel do design industrial no PDP, seus benefícios e seu métodos;

(i) a tendência foi, ao longo do processo, a equipe da empresa desconsiderar as diretrizes de design industrial para a performance de interface para atender o que a engenharia de produto entendia como adequado; muito tempo e saliva tiveram que ser gasto para manter parcial ou totalmente as novas diretrizes e especificações.

\footnotetext{
${ }^{55}$ DfX é a sigla para Design for X, sendo X a característica, ou conjunto de características, de um produto que se deseja otimizar durante o projeto. Exemplos são: DfMA, design for manufacturing and assembly; DfE, design for environment; DfR, design for reciclability; DfD, design for disassembly, entre vários outros. Maiores informações pode ser encontradas, por exemplo, em: ANNES, J. Desenvolvimento de uma metodologia de manufatura consciente para micro, pequenas e médias empresas industriais. Trabalho de Conclusão (Mestrado Profissional). Escola de Engenharia Ambiental, Universidade Federal do Rio Grande do Sul. Porto Alegre, 2003
} 
II - Para as Empresas/Produtos do Nível III:

(a) o PDP foi mais eficiente e produtivo, embora não isento de conflitos, permitindo interações mais profundas entre a engenharia de produto e o design industrial;

(b) a utilização de filosofias de engenharia simultânea do tipo DfX foi mais profunda, permitida pelo estágio inicial em que o produto se encontrava e pelo grau de aceitação da equipe da necessidade da intervenção;

(c) pode-se estudar mais profundamente as necessidade que o produto pretendia atender (técnicas e humanas), deslocando o PDP para reconsiderações sobre qual produto desenvolver, de que forma, em que condições;

(d) a realização de brainstormings multidisciplinares foi eficiente e eficaz, aumentando a capacidade de inovação; foram buscadas à exaustão soluções conjuntas (engenharia e design) para equalizar as diretrizes e especificações de ambas as áreas; em alguns casos, optou-se por soluções totalmente diferentes, mais baratas ou simples, das imaginadas no início do processo;

(e) os resultados desejados foram atingidos, comparativamente, com menos recursos do que as empresas de Nível II, uma vez que o PDP já considerou em seu cerne as diretrizes tanto de performance técnica quanto de interface;

(f) o próprio PDP foi passível de melhorias, uma vez que foi planejado e controlado de forma mais completa. 


\subsection{OBSERVAÇÕES ATRAVÉS DA PERSPECTIVA DO FRAMEWORK PROPOSTO}

O framework proposto orienta que o fenômeno da integração entre design e engenharia no PDP é influenciado por quatro classes de fatores, ou dimensões: especificidades relacionadas ao porte das empresas - no caso, empresas de pequeno porte; dificuldades inerentes ao PDP; aspectos relacionados à lacuna cultural entre designers industriais e engenheiros; ambiente.

Algumas das especificidades das pequenas empresas, conforme o referencial teórico, foram identificadas: participação de familiares na tomada de decisões gerais e no desenvolvimento de produtos; pouca formalização dos processos; funcionários mais antigos e de confiança dos sócios-proprietários controlando o desenvolvimento de produtos; falta de profissionalização do quadro de funcionários geral, bem como dos ligados ao desenvolvimento de produtos; estratégia reativa (inclusive cópia) no desenvolvimento de produtos; recursos financeiros escassos e percepção do design industrial uma despesa desnecessária ou inviável.

O processo de desenvolvimento de produtos apresentou as seguintes características, isoladas ou combinadas em diferentes graus de intensidade: (i) caoticidade; (ii) baseado em conhecimento tácito; (iii) baseado no gosto pessoal de quem desenvolve; (iv) cópia literal ou com pequenas alterações; (v) falta de critérios objetivos; (vi) condicionada essencialmente pelo processo produtivo em detrimento do mercado; (vii) ausência de metodologia organizada e embasada em referenciais teóricos; (vii) baixíssima utilização de fluxo de trabalho digital (modelagem virtual, prototipagem, etc); (viii) ausência de pesquisas de mercado para inputs de projeto e para mensurar os produtos antes do lançamento; (viii) portfolio de produtos desvinculado de planejamento estratégico da empresa; (ix) filosofias e técnicas de engenharia 
simultânea pouco ou totalmente desconhecidas; (x) poucos profissionais com formação em áreas relacionadas ao desenvolvimento de produtos; (xi) inexistência praticamente absoluta de profissionais com formação superior em design industrial ou áreas ligadas ao desenvolvimento de produtos.

Além das dificuldades inerentes ao processo de desenvolvimento de produtos, é possível perceber que as especificidades das MPEs amplificam os problemas, caracterizando o processo de uma forma singular. A escassez de recursos financeiros e humanos parece dificultar, e até mesmo, inviabilizar a adoção de algumas práticas de gestão de projetos e da engenharia simultânea, por exemplo, da forma como teorizadas e praticadas pelas grandes empresas. A influência dos sócios-proprietários e familiares é determinante: sua compreensão sobre design industrial determina tanto a decisão de adotá-lo inicialmente, bem como a forma e intensidade com que será implementado.

Além disso, parece que a lacuna cultural delineada no referencial teórico entremeia o quadro apresentado acima, sendo relevante a sua influência. A lacuna cultural é percebida tanto na incompreensão da importância e do papel do design na competitividade das empresas, quanto nas atividades práticas de projeto, uma vez que a empresa decidiu utilizar o design. Conflitos sobre o papel do designer, realocação do designer para realizar tarefas que os engenheiros não desejam fazer e para tarefas relacionadas à comunicação da empresa e pessoal (como festas, eventos, promoções), desconsideração das decisões tomadas pelo design em relação aos comentários da engenharia e da área de vendas, comentários equivocados e até mesmo preconceituosos, entre outros, puderam ser observados com frequência e de forma muito clara.

Interessante notar que, nas empresas de base tecnológica, onde os quadros de funcionários são bem mais qualificados do que nas empresas tradicionais, a ignorância sobre a 
importância do design e seu papel no PDP é tão disseminado quanto nas empresas "tradicionais". Foi percebida maior resistência inicial nas empresas de base tecnológica para a adoção do design, onde os sócios-proprietários, normalmente mestres ou doutores em áreas de ciências exatas, se mostravam resistentes às abordagens mais relacionadas com os aspectos intangíveis dos produtos. Para estes, conforme o referencial teórico, o produto é o aparato técnico em si. Por outro lado, nos casos em que foi vencida a barreira inicial, grande esforço teve que ser realizado para conciliar as equipes de projeto, os métodos e manter as especificações oriundas do design industrial ao longo do projeto. A tendência era a equipe da empresa demonstrar resistência e até mesmo desconfiança. Por outro lado, observou-se que a posição era de ceticismo, pois uma vez demonstrados os métodos, seus fundamentos e os resultados para a empresa, a receptividade das empresas de base tecnológica parece ter maior intensidade do que as tradicionais. Prova disso é que todas as empresas que tiveram produtos desenvolvidos citados neste trabalho já buscaram novamente integrar o design ao desenvolvimento de outros produtos. Mais que isso, estão buscando faze-lo cada vez mais cedo, o que mostra que perceberam a importância de integrar o design precocemente.

Estas e outras observações permitem inferir que existe uma influência do ambiente, isto é, do contexto (tecnologia, características da concorrência, nível da mão-de-obra envolvida, estratégia adotada, setor, etc) onde ocorre a integração, parecem ter influência no fenômeno, embora este trabalho não tenha focado em detalhar mais profundamente este aspecto.

As classes de fatores (ou dimensões) de influência estabelecidas no framework articulado inicialmente neste trabalho, inferido a partir da literatura, foram úteis para o processo investigativo. As evidências empíricas confirmam preliminarmente a influência das classes de fatores do modelo, embora ainda grande esforço tenha que ser realizado se o 
objetivo for discretizar e/ou correlacionar a influência os fatores - na Figura 4.1 é realizada a tentativa de representar graficamente como as dimensões se articulam. De uma forma geral, pode ser observado que:

(i) o porte da organização tem influência determinante em diversos aspectos, por exemplo, nos recursos disponíveis para contratar interna ou externamente serviços de design industrial, na qualificação da mão-de-obra, no nível de formalização do PDP; as pequenas empresas consideram o design algo desimportante ou um gasto desnecessário, que pode ser feito pelo próprio proprietário, por um familiar ou por um funcionário mais antigo, que “conhece o mercado", quando resolvem contratar serviços de design industrial, não dispõem de recursos suficientes para contratar um profissional formado ou uma empresa qualificada, recorrendo à mão-de-obra desqualificada ou de outras áreas;

(ii) o processo de desenvolvimento de produtos tende a ser mais organizado nas empresas maiores e/ou com mais tempo de existência, embora seja evidente que na maioria das pequenas empresas o processo tem pouca ou mesmo nenhuma formalização; as pequenas empresas aparentam não ter mão-de-obra qualificada nem em número suficiente para controlar o processo adequadamente, em muitos casos, não existe sequer a consciência da necessidade de sistematizar minimamente o processo e, com o tempo, melhorá-lo;

(iii) a lacuna cultural é evidente, resultando na não adoção ou adoção mal-informada do design industrial; os sócios-proprietários das pequenas empresas têm papel determinante nas decisões e nas atividades, com o previsto na literatura, e, na maioria dos casos, é evidente o seu desconhecimento do assunto; o time de projeto, principalmente em empresas de base tecnológica, tende a ser altamente qualificado em áreas das ciências exatas (especialmente nas engenharias), mas apresenta enormes dificuldades em compreender a importância dos atributos intangíveis dos produtos, o papel e os métodos do design industrial, o que complica 
muito o processo; os designers industriais, por outro lado, tem sérias dificuldades em demonstrar seus métodos e seus resultados de forma que os engenheiros aceitem, ficando evidente inclusive que falta aos designers um arcabouço teórico mais robusto e ciência das técnicas e linguajar da engenharia, que permeiam o PDP (muitos designers, por exemplo, nunca tinham ouvido falar de "engenharia simultânea");

(iv) o ambiente parece ter influência na adoção do design. Por exemplo, empresas que sofrem concorrência internacional, que naturalmente utilizam design, se sentem pressionadas a buscar este tipo de serviço quando comparadas à concorrência, embora o façam tardiamente. Este é o caso de muitas empresas de base tecnológica, que, na grande maioria dos casos, desenvolveu os produtos sem a participação de um designer e acreditando que os atributos intangíveis eram irrelevantes ("Design Silencioso"); na última hora, buscam o design na última hora, apenas como maquiagem de produtos. Empresas de confecção, por exemplo, tendem a ser mais permeáveis ao design naturalmente, embora os profissionais envolvidos não tenham formação acadêmica na área e o design seja visto como maquiagem de produto, na maioria dos casos.

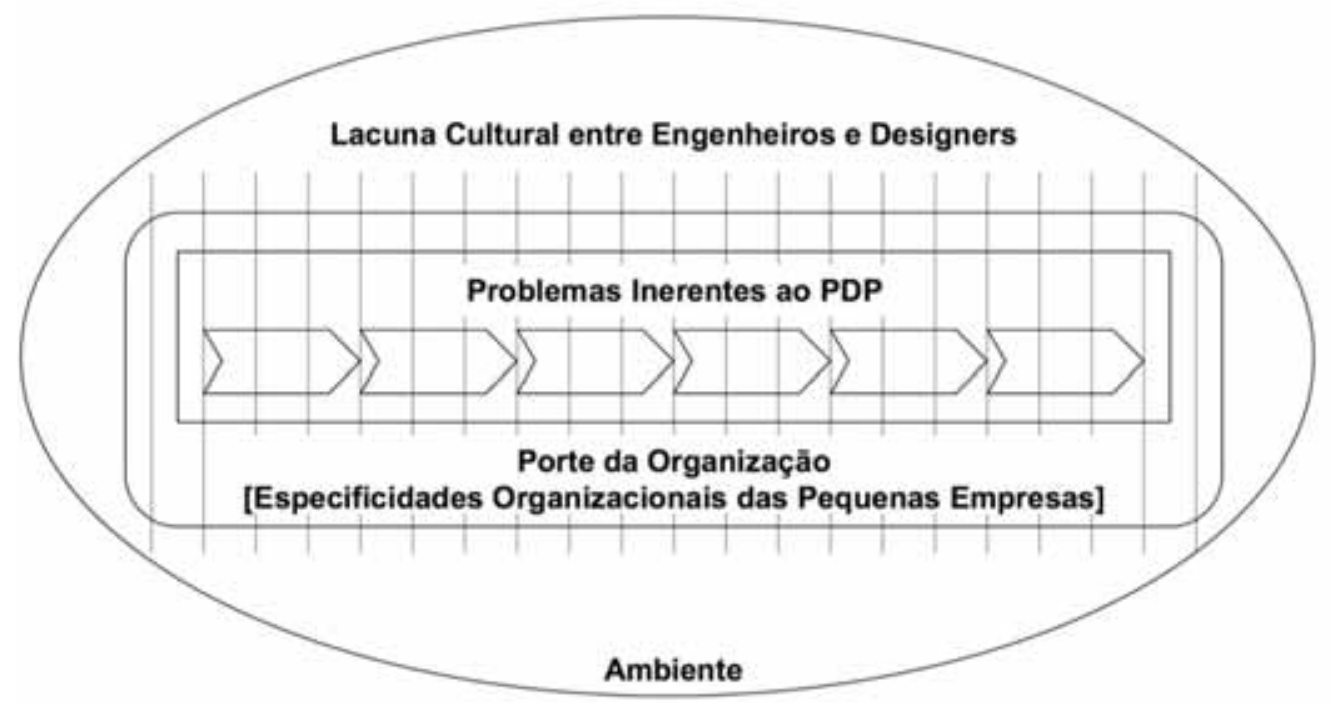

Figura 4.1 - Tentativa de representação gráfica da dinâmica do framework observada na prática 


\subsection{ANÁliSe dOS RESULTAdOS NA PERSPECTIVA DAS PERGUNTAS DE PESQUISA}

$\mathrm{Na}$ perspectiva das perguntas de pesquisa formuladas na seção 1.2.2, os resultados permitem tecer a seguinte análise.

\subsubsection{Sobre a integração precoce do design à engenharia no PDP}

A integração precoce entre design industrial e engenharia no processo de desenvolvimento de produtos é uma "Boa Prática" não praticada pela grande maioria das empresas de pequeno porte consideradas no estudo. Na perspectiva do modelo de "Maturidade de Design" apresentado, são predominantes características do nível "Design Silencioso", praticamente uma posição "não-design” (54\%). Quando existe, o design apresenta características do nível "Maquiagem de Produto" (33\%), tomando a forma de uma intervenção superficial que acontece no final do processo, quando praticamente todas as decisões importantes foram tomadas.

\subsubsection{Sobre os benefícios potenciais da integração precoce para a competitividade}

A partir dos estudos de caso realizados (ver Tabelas 4.3, 4.4 e 4.5); a integração precoce entre design industrial e engenharia de produto pode trazer benefícios para a competitividade dos produtos desenvolvidos:

(i) o mais óbvio e de interesse primário, permite desenvolver produtos que tenham bom desempenho tanto na performance técnica quanto na performance de interface, característica essencial para competir saudavelmente nas condições de competição do mercado atual 
(ii) uma vez que acontece nas fases iniciais, permite a economia de recursos humanos, financeiros; melhor time-to-market;

(iii) permite a utilização adequada de filosofias de DfX;

(iv) potencializa a capacidade de inovação, através da busca de soluções mais adequadas aos usuários, mais simples, mais baratas;

(v) quanto mais precoce a integração, maior parecem ser os benefícios acima.

\subsubsection{Sobre as barreiras para a integração precoce do design ao PDP}

As barreiras para a adequada integração do design industrial à engenharia no PDP parecem ter naturezas diversas, se relacionando mutuamente. Com base neste estudo, é difícil isolar cada variável e mensurar a intensidade de sua influência e seus efeitos. Por outro lado, é possível indicar preliminarmente alguns aspectos destas barreiras.

É certo que as especificidades das micro e pequenas empresas, devido ao seu porte, influenciam na manifestação prática dos conceitos administrativos e de gestão oriundos das grandes empresas, apresentando alto grau de heterogeneidade, pouca formalização dos processos, participação de familiares nas decisões, carência de recursos.

Estas especificidades não apenas se somam aquelas inerentes ao processo de desenvolvimento de produtos, mas o influenciam relevantemente, uma vez que o PDP é um processo que acontece dentro de uma organização. É evidente que a manifestação do PDP nas pequenas empresas, de forma pouco sistemática, é uma barreira para a adequada inserção do design industrial. 
Por outro lado, as entrevistas com profissionais que já trabalharam em médias e grandes empresas no Brasil, indicam que, a despeito de algumas empresas possuírem grandes departamentos de design e engenharia, muitos problemas de integração ocorrem, interferindo relevantemente no processo de desenvolvimento. Desta forma, embora deva ser considerado que o porte da empresa irá melhorar alguns aspectos desta integração, é possível inferir que o tamanho por si só não é suficiente para explicar a problemática da integração entre design e engenharia. Acredita-se que, a despeito do tamanho, a lacuna cultural existente entre designers industriais e engenheiros desempenha um papel fundamental nas difculdades observadas na prática, influenciando tanto no nível decisório, isto é, na decisão de adotar ou não o design e de que forma e intensidade, quanto no nível prático, no cerne do desenvolvimento, onde é definida a eficiência com que esta integração acontecerá na prática e, consequentemente, os resultados do processo (produtos).

As "Boas Práticas" propostas (ver Quadro 3.1) foram sendo adaptadas, ao longo do processo, à realidade encontrada na inserção do design no PDP das pequenas empresas e suas barreiras, resultando na seguinte dinâmica (ver Figura 4.2):

(i) a integração precoce no PDP é a boa prática principal e dependeu da conscientização (convencimento) do sócio-proprietário da empresa da importância do design, o que foi feito através de palestra e reuniões com dados teóricos e casos de sucesso, demonstrando a importância do design para a competitividade da empresa e que a adoção no início do projeto é a mais indicada;

(ii) de nada adianta ter uma integração precoce se as diretrizes de design forem sobrepujadas ou desconsideradas pela engenharia ao longo do processo (o que é um dos principais problemas). Isso significou conscientizar a equipe 
da empresa sobre a importância, os métodos e os critérios de avaliação do design, através de palestras e reuniões. Ao longo do processo, foi essencial tem um champion ou sponsor na equipe de engenharia, que compreendeu este aspecto e influenciou os outros (tanto melhor se este for o próprio proprietário, dada a influência determinante que o mesmo tem nas empresas de pequeno porte, ou um membro do time da empresa respeitado, pelo grau acadêmico, tradição e/ou competência prática). O treino dos designers industriais também é determinante, preparando-os para conversar e discutir com os engenheiros em nível técnico similar, sendo o treino e utilização de técnicas e jargões da engenharia um fator de atenuação dos conflitos. Particularmente importante foi a adoção - após a fase de conceituação - pela equipe de design, de software para modelagem CAD 3D de engenharia, ao invés dos comumente utilizados pelos designers. Esta medida parece ter facilitado a comunicação entre os times, tanto por motivos técnicos (como a conversão adequada de arquivos de projeto ao longo das fases, trabalho virtual integrado, modificações e manutenção da integridade do projeto, etc) como por motivos mais simbólicos, parecendo emprestar aos designers uma aura mais "engenheirística", o que permitiu se "misturar" mais facilmente aos times de engenharia;

(iii) a participação de todo o time nas atividades principais pareceu atacar diversas causas de problemas e se prestar a melhor integração do time. $\mathrm{Na}$ prática, significou convidar os engenheiros para participar de sessões de observação de usuários, visitar pontos de venda de produtos, participar de sessões de role-playing e brainstormings de pensamento divergente, bem 
como os designers participarem de simulações com método de elementos finitos, visitar fornecedores, discutir aspectos técnicos de materiais, etc. A despeito da contribuição de cada profissional na área do outro (que por motivos óbvios, pode ser pequena ou nula), este tipo de abordagem pareceu esclarecer à equipe como e por que alguns aspectos são investigados, quais os motivos da decisão tomada, quais os critérios de avaliação e porque algumas diretrizes e especificações não poderiam ser mudadas, sem prejuízo ao projeto, o que antes seria motivos de conflito. Esta abordagem do tipo Hot Team, como observado na literatura, foi muito proveitosa em atenuar diferenças, criar um clima de camaradagem, manter a visão do conceito e a sua integridade ao longo do projeto, além dos benefícios mais objetivos que trouxe na compreensão do problema e das soluções geradas, que se refletirão na qualidade do produto final;

(iv) A prototipagem precoce e frequente é uma boa prática que objetivou tanto observar as soluções adotadas e prevenir problemas antecipadamente, quanto facilitar a comunicação da equipe. Na prática, as pequenas empresas nem sempre dispunham de recursos suficientes para confeccionar vários protótipos físicos mais elaborados, utilizando métodos de prototipagem rápida como FDM ou SLS. Foram adotados protótipos alternativos, em papel, papelão, espuma, isopor, restos de materiais, madeira, ficando os protótipos mais elaborados para o final. Todos eram incentivados a prototipar, interagir com equipe e com os protótipos. Os benefícios novamente foram, além daqueles técnicos e financeiros relacionados às vantagens da prototipagem, a melhora da comunicação da equipe, maior camaradagem e redução de conflitos. 


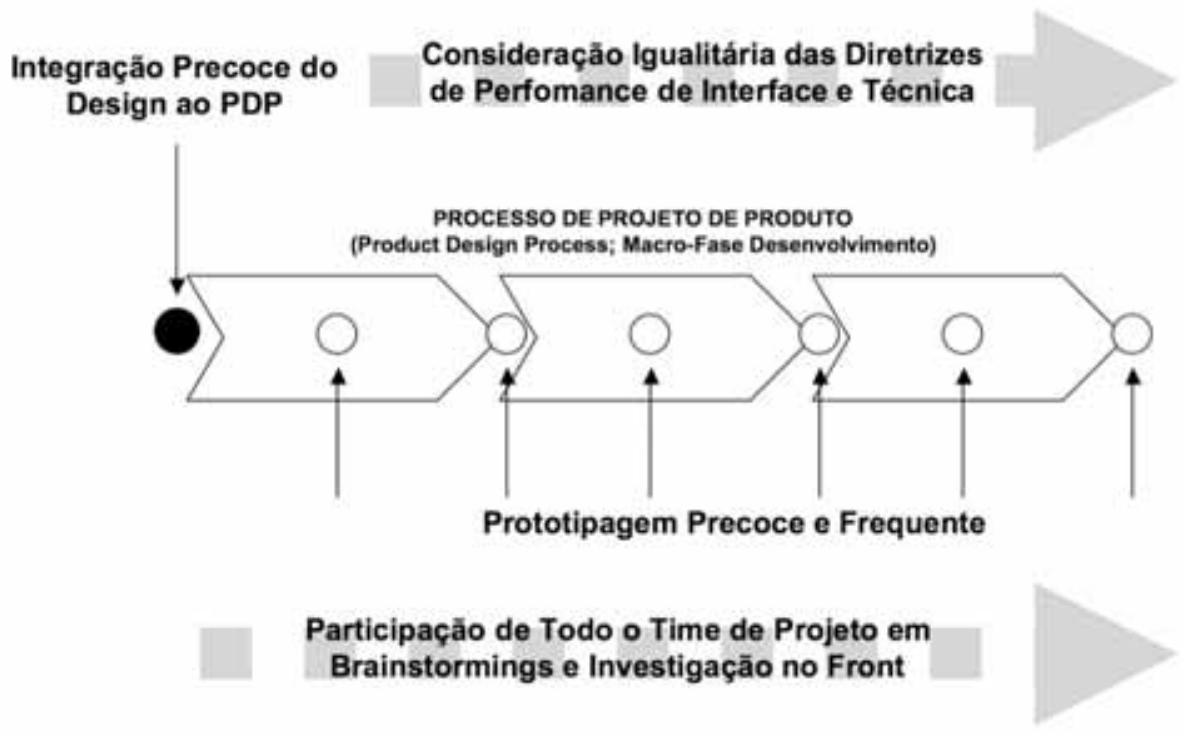

Figura 4.2 - Representação gráfica da aplicação das "Boas Práticas” ao PDP

\subsubsection{Sobre a implicações das barreiras ao PDP das empresas e a competitividade}

As implicações que se pode inferir destas barreiras são:

(i) desenvolvimento de produtos com uma visão orientada apenas pelos aspectos técnicos, isto é, privilegiando a performance técnica em detrimento da performance de interface, o que pode prejudicar sua chance de sucesso no mercado atual, principalmente em segmentos onde a competição é árdua;

(ii) falta de eficiência no PDP, considerando que os produtos necessitam de um novo de desenvolvimento para equalizar a performance a um nível desejado, pois é possível supor que despendam recursos desnecessários - recursos humanos, material de consumo, energia elétrica, combustível, materiais, contato com fornecedores, telefones, internet, viagens, etc para atingirem um resultado satisfatório para competirem saudavelmente;

(iii) perda de eficácia na transformação de ciência básica em tecnologia e desta em produtos efetivamente comercializados no mercado (ciclo de inovação tecnológica); 
(iv) diminuição da capacidade de inovação, considerando o design thinking é reconhecidamente um catalisador da inovação. 


\section{CONSIDERAÇÕES FINAIS}

Este trabalho investigou o fenômeno da integração entre design industrial e engenharia no processo de desenvolvimento de produtos, com ênfase nas empresas brasileiras de pequeno porte.

A investigação foi delimitada e orientada por uma revisão bibliográfica ampla, uma fundamentação teórica articulada criticamente e por perguntas de pesquisa. Foram propostos, como ferramentas conceituais para o processo investigativo, um framework, que buscou estabelecer as classes de fatores ou dimensões que influenciam o fenômeno, e um conjunto de "Boas Práticas", que pudesse ser utilizado como parâmetro comparativo para a realidade, bem como para a aplicação prática em estudos de caso. Também foram levantados e utilizados o "Modelo de Maturidade de Design" - do tipo "Escada do Design", para classificação das empresas em relação à inserção do design nos seus processos, e a "Ferramenta de Auditoria do Produto", para a avaliação do resultado do processo de projeto, o produto, através de dimensões-chave, bem como oferecer indícios sobre características do processo em si. A pesquisa de campo, do tipo pesquisa-ação, envolveu visitas às empresas, entrevistas com empresários e participantes dos processos de desenvolvimento, análise documental e participação ativa em casos reais de desenvolvimento de produtos.

Os pressupostos do trabalho, estabelecidos através da literatura, indicam que o desenvolvimento de produtos é reconhecidamente uma atividade estratégica para a transformação de conhecimento em riqueza na atualidade, sendo altamente desejável integrar o design industrial à engenharia, de forma a projetar produtos que tenham tanto boa performance técnica quanto boa performance de interface. A despeito das sólidas evidências da correlação positiva entre a integração do design industrial à engenharia neste processo e o desempenho comercial das empresas, as empresas de pequeno porte tendem a apresentar 
deficiências neste aspecto. Assim sendo, com o objetivo de avaliar a utilização do design, são utilizados, internacionalmente, "Modelos de Maturidade de Design", classificando as empresas de acordo com a sua compreensão, intensidade e forma como inserem o design nas atividades da empresa. As pequenas empresas tendem, mundialmente, a ser concentrar nos níveis mais baixos do modelo, onde o design é negligenciado, realizado por pessoas sem formação específica ou utilizado superficialmente, como uma espécie de maquiagem do produto.

O "Modelo de Maturidade de Design" em relação ao modelo de fases do PDP e a "Boa Prática" primária proposta indicam que, de forma geral, a condição básica para se beneficiar da utilização do design é integrá-lo precocemente ao processo de desenvolvimento de produtos. Além disso, verificou-se a necessidade de adotar "Boas Práticas" secundárias, como forma de maximizar a manutenção das diretrizes do design industrial ao longo do processo e assegurar a boa comunicação entre designers e engenheiros, especialmente nas empresas de pequeno porte.

A classificação da amostra de empresas na perspectiva do modelo de maturidade permite afirmar que a grande maioria das empresas de pequeno porte brasileiras situa-se nos dois níveis mais baixos, entre os quatro possíveis. É relevante, e preocupante, que aproximadamente $87 \%$ das empresas se situem nos dois níveis mais baixos do modelo, sendo que mais de $50 \%$ das empresas estejam no nível mais baixo, denominado "Design Silencioso" ou "Não-Design", onde o design industrial é desconhecido, ignorado ou executado por pessoas sem formação na área. A distribuição das empresas de base tecnológica é muito semelhante, o que torna ainda mais preocupante o quadro, pois este tipo de empresa é considerado um instrumento para transformação de conhecimento em riqueza. Mais 
preocupante ainda é o baixíssimo número de empresas no terceiro e quarto níveis, onde é desejável que se situem empresas de inovação e valor agregado.

Os estudos de caso de desenvolvimento de produtos para empresas de base tecnológica, com a aplicação do conjunto de "Boas Práticas", permitem afirmar, como o esperado, que os produtos desenvolvidos com a integração precoce do design industrial ao processo tendem a obter melhor performance de interface (com melhoria também na performance técnica), o que potencialmente melhora suas chances de competição no mercado atual. Além disso, os estudos de caso utilizados sugerem que as empresas que adotam inicialmente este tipo de abordagem economizam recursos humanos e financeiros, tem melhor time-to-market, tem maior capacidade de utilização adequada de métodos de engenharia simultânea do tipo DfX, potencializam a sua capacidade de inovação. A tendência parece tanto maior quanto mais precoce a integração.

Os estudos de caso também demonstraram que é necessário adaptar as "Boas Práticas" para sua aplicação em empresas de pequeno porte, o que era previsto pelo referencial teórico. Empresas de pequeno porte apresentam especificidades organizacionais que as distinguem das grandes empresas e, portanto, não se pode aplicar diretamente conceitos e práticas oriundas deste porte de empresa nas empresas de pequeno porte. A conscientização (convencimento) do sócio-proprietário da empresa sobre a importância de integrar o design ao processo; a conscientização da equipe da empresa sobre a importância, os métodos e os critérios de avaliação do design; a existência de um champion ou sponsor da integração na equipe de engenharia; o treino dos designers industriais para conversar e discutir com os engenheiros em nível técnico similar; a adoção, pela equipe de design, de software de engenharia, tanto por motivos técnicos quanto simbólicos; a participação de todo o time nas atividades principais; a prototipagem precoce e frequente, mesmo que em papel, papelão, espuma, 
isopor, restos de materiais, madeira; foram manifestações das "Boas Práticas", adotadas de formas simples, mas que se mostraram adequadas à dinâmica das empresas de pequeno porte.

As principais barreiras que puderam ser observadas parecem se influenciar mutuamente: limitação de recursos humanos e financeiros; baixa formalização dos processos; falta de clareza do posicionamento estratégico; baixa qualidade das informações necessárias ao desenvolvimento de projetos de produto; baixíssima formalização ou sistematização do processo de desenvolvimento de produtos; dificuldade de comunicação e relacionamento entre designers e engenheiros, podendo chegar ao preconceito, velado ou explícito; ênfase demasiada no desempenho técnico em detrimento do desempenho nos atributos intangíveis dos produtos; estratégia de competição baseada na cópia de importados ou "engenharia reversa", em detrimento de inovação. Estas observações empíricas sustentam a validade das dimensões, ao menos preliminarmente, do framework proposto. As "Boas Práticas" adaptadas às empresas de pequeno porte permitiram contornar ou amenizar estas barreiras, embora seja evidente que integração precoce do design industrial ao PDP é uma prática negligenciada pelas empresas de pequeno porte brasileiras.

De uma forma geral, a situação observada é pouco propícia para a integração do design industrial à engenharia no processo de desenvolvimento de produtos, principalmente devido à falta de compreensão, em níveis mínimos, sobre a contribuição que esta área pode trazer para a competitividade dos produtos. Sem esta base, as empresas parecem nem mesmo saber que está faltando um importante ingrediente para a competição na atualidade. Não pode ser esquecido que, ainda que despertem o interesse em trazer o design ao processo, tal empreitada provavelmente será feita de forma tardia e de forma superficial, prejudicando o seu impacto no resultado do processo. As "Boas Práticas" propostas podem minimizar as barreiras observadas, mas isso apenas nos casos em que se optou pela integração. 
Embora fosse esperado, através da literatura existente, certo grau de incompreensão e/ou negligência das empresas de pequeno porte em relação ao design, a situação no Brasil parece ser ainda distante dos países desenvolvidos, como pode ser observado pela distribuição das suas empresas de acordo com a maturidade. Esta observação com certeza tem impacto direto na competividade nos produtos brasileiros em relação aos produtos oriundos de países desenvolvidos, especialmente nos produtos de consumo.

Neste momento, o desafio para o Brasil parece ser criar condições para que as empresas subam para o segundo degrau da "escada do design", onde as características são mais propícias para elevá-las ao terceiro e quarto degraus e, assim, atingir um patamar em que possam alcançar o design comprovadamente catalisa a inovação e torna as empresas mais competitivas.

\subsection{IMPLICAÇÕES PARA A TEORIA, PRÁTICA E LIMITAÇÕES}

Este trabalho emanou da experiência prática do pesquisador como coordenador de um grupo que tem por objetivo promover o design industrial como fator de aumento da competitividade para empresas de pequeno porte de diversos setores. A experiência deste grupo é muito rica, sendo adquirida em um dos pouquíssimos grupos que existem para promover o design no país, o que, naturalmente, conduziu ao enfrentamento diário das grandes dificuldades deste tipo de iniciativa. A suspeita é que seja uma experiência praticamente única no país, pois no mesmo espaço, se encontram designers industriais e engenheiros de diversas áreas, buscando integrar as duas atividades. O fato desta iniciativa tomar lugar numa instituição que implantou a incubadora de empresas pioneira no país - a primeira da América Latina - e mantém nove outras incubadoras na região e possui diversos outros programas, como um parque tecnológico, permitiu também o contato íntimo com o 
empreendedorismo, e isto não é menos relevante. Acrescenta-se ainda, o contato diário com incubadoras de empresas, Arranjos Produtivos Locais, agência de fomento e grupos de pesquisa de diversas áreas espalhados por São Paulo, outros estados e até mesmo países.

Ao longo desta experiência, cheia de vitórias e fracassos, surgiram naturalmente muitas dúvidas e dificuldades. Parte das repostas foi encontrada na prática. Mas, como é natural ao espírito científico, elevou-se a necessidade de desenvolver estudos que possam compreender, explicar, sistematizar e melhorar a prática. Assim surgiu este trabalho.

A literatura brasileira não forneceu um arcabouço específico e robusto para o estudo do fenômeno, limitando-se a identificar e reconhecer que existem algumas deficiências. A literatura internacional é mais profícua e fundamentada, razão pela qual foi utilizada como base para o delineamento do fenômeno, a construção de um framework e um conjunto de "Boas Práticas", que orientaram este análise exploratória. Exploratória, pois se enfrenta um problema pouco compreendido, onde não se conhecem exatamente seus contornos, suas variáveis, suas interações e correlações, faltam orientações teóricas e ferramentas para a sua abordagem. Alguns até mesmo tem dificuldade em identificar e aceitar que existe um problema - o que, na realidade, faz parte do problema. Por este motivo, parte deste trabalho buscou demonstrar que a falta de integração entre design e engenharia, é, na realidade, um problema a ser considerado, estudado e superado. Por ser exploratório, este estudo não é conclusivo, nem pretende ser. Consonante à sua natureza, pretende ser exatamente o contrário, um ponto de partida. Seu objetivo é demonstrar que existe um fenômeno e quais são os seus contornos, quais os caminhos frutíferos para se seguir, quais questões estão sem resposta, quais perguntas podem ser feitas.

Assim sendo, ambiciosamente, arriscou-se propor um framework, que se mostrou adequado para a análise e acredita-se que as suas dimensões fornecem uma boa base inicial 
para investigações futuras e construção de um modelo mais robusto. A construção do framework baseou-se na classificação dos fatores identificados como tendo influência no complexo fenômeno da integração, resultando em dimensões-chave para análise: (i) porte da empresa; (ii) problemas inerentes ao PDP; (iii) lacuna cultural entre designers e engenheiros; (iv) ambiente/contexto. Espera-se que trabalhos futuros possam confirmar ou refutar estas dimensões, estabelecer correlações mais robustas entre elas, complementar e detalhar melhor o modelo, ou, até mesmo, descartá-lo.

As "Boas Práticas" propostas permitem afirmar que: (i) a integração precoce do design industrial ao processo de desenvolvimento é essencial; (ii) deve ser acompanhada da consideração da performance de interface além da performance técnica dos produtos e de medidas para a consideração igualitária das diretrizes e especificações da primeira ao longo do processo; (iii) a investigação dos usuários no front, a participação conjunta da equipe nas investigações diversas e brainstormings e a prototipagem precoce e frequente podem contribuir para manter a visão do produto, a consideração igualitária das diretrizes de ambos os tipos de performance e melhoria da comunicação entre designers industriais e engenheiros da equipe. Espera-se que o setor produtivo possa aplicar, aprimorar, propor, descartar estas "Boas Práticas", porque, se assim for, este trabalho terá tido algum impacto onde realmente deve acontecer a integração entre o design e a engenharia: nos milhares de empresas espalhadas pelo Brasil, especialmente as de pequeno porte.

O modelo de "Maturidade de Design" - que fornece uma ferramenta para classificar e estudar as empresas de acordo com a sua compreensão, intensidade e forma como insere o design nas suas atividades - e a "Ferramenta de Auditoria do Produto" - que fornece uma ferramenta robusta para avaliar a situação do produto atual em relação à importância dada pelo usuário a dimensões-chave do produto e permite tanto a avaliação e melhoria do produto 
quanto indícios da necessidade de melhoria do processo de desenvolvimento - completam o levantamento e articulação de ferramentas que foram aplicadas neste trabalho e fornecem também um ponto de partida para trabalhos futuros e para a avaliação da própria prática nas empresas.

O fato da amostra de empresas não ter sido dimensionada para adequar-se à proporção de porte, setores e outros características do Brasil, mas baseada nas empresas que a os Núcleos de Design Industrial e Engenharia da Fundação Parqtec teve relacionamento ao longo de um período; a utilização predominante, mas não exclusiva de pequenas empresas; a utilização exclusiva de empresas do Estado de São Paulo; a variedade de setores; a existência de muitas empresas em fase inicial (micro empresas e start-up); a análise documental de instrumentos não projetados especificamente para este estudo, embora completos, e uma série de outros aspectos podem ter distorcido os resultados.

Entretanto, dada a consonância dos achados com a literatura prévia, a característica peculiar das empresas brasileiras de possuir pouquíssimos funcionários - assim como na amostra, o fato do Estado de São Paulo (responsável por 100\% das empresas da amostra) possuir mais de $30 \%$ das empresas de pequeno porte do Brasil e ter perfil próximo do encontrado nacionalmente, pode-se argumentar que os desvios são aceitáveis para um trabalho exploratório, cuja função primordial pode ser encarada como situar preliminarmente um fenômeno e permitir o levantamento de hipóteses futuras mais específicas e profundas. Através dos mesmos argumentos, acredita-se que é possível, até que sejam realizados estudos específicos e com amostra estratificadas adequadamente, generalizar a situação para as empresas de pequeno porte do Brasil.

Apesar da dificuldade em se generalizar estudos de caso, acredita-se que, somados à classificação das empresas no modelo de maturidade e aos outros resultados, este estudo 
possa servir ao menos como indício para a aceitação de uma realidade pouco desejável em relação à integração entre design e engenharia. A aceitação desta realidade pode conduzir a estudos acadêmicos mais profundos e modificações na prática do setor produtivo.

É digno de nota que, mesmo antes de ser publicado, alguns reflexos já podem ser observados, como os diversos contatos de diversos departamentos de engenharia, antes pouco permeáveis ao tema, com interesse em promover certa integração com o design no nível acadêmico, bem como por parte do setor produtivo, onde muitas empresas tem se interessado em promover a integração do design à engenharia no desenvolvimento dos seus produtos. Dos casos utilizados neste trabalho, $90 \%$ das empresas já retornaram para o segundo ou terceiro projeto, buscando o design de forma cada vez mais precoce.

Tudo indica que a lacuna cultural entre designers industriais e engenheiros, mais do que todas as dimensões do framework, é talvez a maior barreira a se transpor, mas também é a que, uma vez transposta, trará os melhores resultados. E esta barreira só será transposta realmente quando for tratada preventivamente no nível da educação, a exemplo das experiências de alguns países. Isto significa levar o design industrial para os Departamentos de Engenharia, na graduação e na pós-graduação, mais do que levar a engenharia aos Departamentos de Design, embora também importante. Este parece ser um excelente objeto de pesquisa e de iniciativas práticas.

Outro aspecto visível é a necessidade de se buscar modelos de referência e prática em desenvolvimento de produtos para empresas de pequeno porte, adequadas à sua realidade. Integrar o design à engenharia será muito difícil sem um processo de desenvolvimento de produtos, que o palco onde interagem estas duas áreas, sistematizado, robusto e realmente adaptado às especificidades organizacionais. Este parece ser um desafio a ser enfrentado nos próximos anos pela academia e pelo setor produtivo, se o objetivo for competir num mercado 
global cada vez mais baseado na transformação de conhecimento em riquezas, através de produtos.

As implicações da situação observada neste trabalho, especialmente para as empresas de base tecnológica, que parece ser pouco propícia ao desenvolvimento de produtos que possam competir saudavelmente num mercado que cada vez mais valoriza os atributos intangíveis dos produtos, podem ser resumidas para o Brasil de forma similar à preocupação que MOODY expressa na conclusão de seu artigo em relação à situação britânica em 1980: “a oposição dos engenheiros para empregar designers industriais é amplamente difundida. Como os engenheiros têm um papel central na inovação tecnológica, sua atitude perante o design industrial é crucial. Há motivo para preocupação se o progresso da inovação tecnológica é atrasado pelo preconceito dos engenheiros". 


\section{REFERÊNCIAS BIBLIOGRÁFICAS}

AMARAL, D. C. Arquitetura de conhecimentos explícitos sobre o processo de desenvolvimento de produto. 2002. 231 f. Tese (Doutorado) - Curso de Engenharia Mecânica, Universidade de São Paulo, São Carlos.

ARGAN, G. C. Arte Moderna. São Paulo: Companhia Das Letras, 1992. 709 p.

BAARS, E. M. A Gestão do Design no Contexto das Empresas e Orgãos de Fomento à Indústria de Santa Catarina. 2002. 147 f. Dissertação (Mestrado) - Departamento de Programa de Pósgraduação em Engenharia de Produção, Universidade Federal de Santa Catarina, Florianópolis.

BAXTER, M. Projeto de produto: guia prático para o design de novos produtos. São Paulo: Edgard Blucher, 1998.

BERKOWITZ, M. Product shape as a design innovation strategy. Journal Of Product Innovation Management, v. 4, n. 4, p.274-283, dez. 1987.

BONSIEPE, G. Design: do material ao digital. Florianópolis: FIESC/IEL, 1997.

CARTER, D.e; BAKER, B.s. Concurrent engineering: the product development enviroment for the 1990s. Massachusetts: Wesley Publishing Company, 1992.

CENTRE FOR DESIGN INNOVATION (Ireland). ITSBIC. The design difference: a survey of design and innovation. Ballinode: Centre For Design Innovation, 2007. 20 p.

CLARK, K.B.; FUJIMOTO, T. Product development performance: strategy, organization and management in the world of auto industry. Boston-Mass: Harvard Business School Press, 1991.

CLAUSING, D. Total quality development: a step-by-step guide to world class concurrent engineering. 2. ed. Nova Iorque: ASME Press, 1994. 172 p.

CREUSEN, M. E. H.; SCHOORMANS, J. P. L. The Different Roles of Product Appearance in Consumer Choice. Journal of Product Innovation Management, v. 22, n. 1, p. 63-81, jan. 2005

Design Council (Reino Unido). The Impact of Design on Stock Market Performance: An Analysis of UK Quoted Companies 1994-2003, Design Council, 2004.

DIAS, Maria Regina Álvares Correia. O ensino do design: a interdisciplinaridade na disciplina de projeto em design. 2004. 176 f. Dissertação (Mestrado) - Departamento de Programa de Pósgraduação em Engenharia de Produção, Universidade Federal de Santa Catarina, Florianópolis, 2004.

ELGAN, M. The eight secrets that make Apple number 1. Computerworld, 14 setembro 2007. Disponível em:<http://www.computerworld.com.au/index.php/id;715190944>. Acesso em: 01 janeiro 2007.

ESCRIVÃO FILHO, E. et al. Compreendendo a dinâmica das pequenas empresas: mapa organizacional como ferramenta da ação administrativa. Matiz, v. 1, n. 1, p.20-40, $2^{\circ}$ semestre de 1995.

CÉSAR, R. Sete lições da Apple (que podem turbinar qualquer empresa). Exame, São Paulo, v. 41, n.12, p.23-30, 04 julho 2007.

GOMEZ, P. A. O design como diferencial competitivo para alavancar as exportações das pequenas e médias empresas do setor moveleiro. Curitiba, 2005, 176f. Dissertação (Mestrado) Programa de Pós-Graduação em Engenharia de Produção, Pontifícia Universidade Católica do Paraná.

FASCIONI, L. C. Indicadores para avaliação da imagem corporativa das empresas de base tecnológica instaladas na grande Florianópolis baseados nas análises das percepções gráfica e verbal utilizando lógica difusa. Florianópolis, 2003, Tese (Doutorado) - Programa de Pós-graduação em Engenharia de Produção, Universidade Federal de Santa Catarina. 
FERREIRA, C. V.; SANTOS, N. L.; PAES, A.; GODOY, M. Design industrial no processo de desenvolvimento integrado de produto como ferramenta estratégica para otimização, diferenciação e inovação. In: Congresso Brasileiro de Gestão de Desenvolvimento de Produtos, 4, 2003. 4 CBGDP. Porto Alegre, RS : FEENG, 2003. v. CDROM. p. 10p.

FISHER, R.; URY, W. Getting to yes: negotiating agreement without giving in. Penguin Books, New York: 1991.

GEMSER, G; LEENDERS, M. A. A. M.. How integrating industrial design in the product development process impacts on company performance. The Journal Of Product Innovation Management, Malden, v. 18, n. 1, p.28-38, 2001.

MICROGIANTS INDUSTRIAL DESIGN GMBH (Austria). The Austrian Design Ladder: executive summary. Vienna: [s.n.], 2006. 3 p. Disponível em: <http://www.microgiants.com/proj/designleiter/EXE_engl_20060728.pdf>. Acesso em: 19 jan. 2008.

GOMEZ, P. A. O design como diferencial competitivo para alavancar as exportações nas pequenas e médias empresas do setor moveleiro. Curitiba, 2005. 178f. Dissertação (Mestrado) Pontifícia Universidade Católica do Paraná.

HERTENSTEIN, J. H.; PLATT, M.; VERYZER, R. W. (2005) The Impact of Industrial Design Effectiveness on Corporate Financial Performance. Journal of Product Innovation Management, v. 22 , n. 1, p. $3-21$

HESKETT, J. Desenho industrial. 2. ed. Rio de Janeiro: José Olympio/UNB, 1998. 228 p.

HOLT, K; GESCHKA, H; PETERLONGO, G. Need assessment: a key to user-oriented product innovation. Chichester: John Wiley \& Sons, 1984. 187 p.

HOLT, K. Does the engineer forget the user? Design Studies Journal, [s.1.], v. 10, n. 3, p.163-168, 1989.

IDEO (Califórnia). Design thinking at Davos: Tim Brown and IDEO Visit Davos. Disponível em: <http://www.ideo.com/media/events/info.asp?x=3>. Acesso em: 31 mar. 2007.

IDEO (Califórnia). Website da empresa IDEO. Disponível em: <http://www.ideo.com>. Acesso em: 31 mar. 2007.

INSTITUTE FOR MANUFACTURING (Reino Unido). Departamento de Engenharia Mecânica Cambridge. A guide to effective product design. Disponível em: 〈http://www.ifm.eng.cam.ac.uk>. Acesso em: 10 jul. 2007.

JOHANSSON, U. Summary of Design as a force for development: an evaluation of government's investiment in design 2003-2005. Växjö: School Of Management And Economics, 2006.

JOURNAL OF PRODUCT INNOVATION MANAGEMENT. Malden: Blackwell Publishing, v. 18, n. 1, jan. 2001.

JUHLER, H. Markedsorientert produktutvikling: metoder for behovsstudiet. 1986. $173 \mathrm{f}$. Dissertação (Mestrado) - Departamento de Norwegian Institute Of Technology, University Of Trondheim, Trondheim.

JULIEN, P.A. Lês PME bilan et perspectives. Quebec: Economica, 1997.

KELLEY, T; LITTMAN, J. The art of innovation: lessons in creativity from IDEO, America's leading design firm. New York: Double Day/random House, 2001.

KINDLEIN JUNIOR, W; GUANABARA, A. S. A Importância do Binômio Design e Engenharia como Catalisador de Inovação. In: CONGRESSO DE PESQUISA E DESENVOLVIMENTO EM DESIGN - P\&D2006, 7, 2006, Curitiba. $7^{\circ}$ Congresso de Pesquisa e Desenvolvimento em Design P\&D2006. Curitiba: P\&d2006, 2006.

KOTLER, P. Administração de marketing. São Paulo: Editora Atlas, 1998 
KRISTENSEN, T. et al. Is good design good for business? In? NORDIC ACADEMY OF MANAGEMENT (NFF) CONFERENCE, 19, 2007, Berger. 19th Nordic Academy of Management (NFF) Conference. Berger: NFF.

LEE, T.Y.; RADCLIFFE, D.F. Innate design abilities of first year engineering and industral design students. Design Studies Journal, v. 11, n. 2, p. 96-106, abr. 1990.

LOBACH, B. Design industrial: bases para a configuração de produtos industriais. São Paulo: Ed. Edgard Blucher, 2001.

LORENZ, C. Harnessing design as strategic source. Long Range Planning: International Journal of Strategic Management, Londres, v. 27, n. 5, p.73-84, 1994.

LUZA, R. P. A visão empresarial sobre o designer na indústria moveleira: um elemento agregador de valor. 2003. 120 f. Dissertação (Mestrado) - Curso de Pós- Graduação em Engenharia de Produção, Universidade Federal de Santa Catarina, Florianópolis, 2003.

MAEDA, J. As leis da simplicidade: design, tecnologia, negócios, vida. São Paulo: Novo Conceito, 2007.

MAGALHÃES, C. Design estratégico: integração e ação do design industrial. Estudos em design. v. 3, n. 1, p.1-12, 1995.

MARTINS, R. F. F. A gestão de design como uma estratégia organizacional: um modelo de integração do design em organizações. 2004. Tese (Doutorado). Programa de Pós-graduação em Engenharia de Produção, Universidade Federal de Santa Catarina , Florianópolis, 2004

MCBURNIE, T; CLUTTERBUCK, D. The marketing edge. Londres: Penguin Books, 1987. p.191.

MOODY, S. The role of industrial design in tecnnological innovation. Design Studies Journal, v. 1, n. 6, p.329-339, out. 1980.

MOULTRIE, J. , CLARKSON, P.J. , PROBERT, D. Development of a design audit tool for SMEs. Journal of Product Innovation Management, Malden, v. 24, n. 4, p.335-368, jul. 2007.

MOULTRIE, J.; FRASER, P.; CLARKSON, P.J. The innovation-styling spectrum:factors constraining the design ambition of UK SMEs. In: INTERNATIONAL DESIGN CONFERENCE, 7 , 2002, Dubrovnik. Proceedings do $7^{\text {th }}$ International Design Conference. Glasgow : Faculty of Mechanical Engineering and Naval Architecture, University of Zagreb and The Design Society, 2002.

MOULTRIE, J.; FRASER, P. Better product design: assessing and improving product design capability. Cambridge: IFM, 2004.

NATIONAL AGENCY FOR ENTERPRISE AND HOUSING OF DENMARK; DANISH DESIGN CENTRE (Dinamarca). The economics effects of design. Copenhagen: NAEH/DDC, 2003.

NIEMEYER, L. Design no Brasil: origens e instalação. 2. ed. Rio de Janeiro: 2ab Editora, 1998. 126 p.

PROGRAMA BRASILEIRO DE DESIGN. Apresentação de lançamento do Programa Brasileiro de Design. Brasília: Ministério da Indústria, do Comércio e do Desporto, 1995.

Peters, $\mathrm{T} \mathbf{J}$ and Waterman, R H. In search of excellence: lessons from America's best run companies. Nova Iorque: Harper \& Row, 1982. p. 360.

PEVSNER, N. Origens da arquitetura moderna e do design. 3. ed. São Paulo: Martins Fontes, 2001.

PEVSNER, N. Pioneers of modern design: from William Morris to Walter Groupius. Harmondsworth: Penguin Books, 1974.

PEVSNER, N. Pioneiros do desenho moderno: de William Morris a Walter Gropius. 3. ed. São Paulo: Martins Fontes, 2002. Tradução de João Paulo Monteiro. 
PHILIPS (Brasil). Design: Royal Philips. Disponível em: <http://www.design.philips.com/ >. Acesso em: 21 jan. 2007.

PINE II, B. J. Customização maciça: demanda e produção flexíveis: personalizando produtos e serviços. São Paulo: Makron Books, 1994.

ROOZENBURG, N.F.M.; CROSS, N. G. Models of the design process: integrating across the disciplines. Design Studies Journal, v. 12, n. 4, p. 215-220, out 1991.

ROUSOE, M. Making sense for people: interviewving Stefano Marzano. Danish Design Center. Disponível em: <http: //www.ddc.dk/ DESIGNVIDEN/artikler/DN_01_06_StefanoMarzano>. Acesso em: 12 ago. 2007.

ROZENFELD, H.; VEGA, H.A. Ambiente distribuído de soluções para suportar a engenharia simultânea. Máquinas e metais, v. 32, n. 350, p.211-223, mar. 1995.

ROZENFELD, H.; SILVA, S. L. Uma proposta de gestão do conhecimento no desenvolvimento de novos produtos. 1998. Disponível em <http://www.ifm.org.br>. Acesso em: 30 mai 2007.

ROZENFELD, H.; FORCELINNI, F. A.; AMARAL, D. C.; TOLEDO J. C.; SILVA, S. L.; ALLIPRANDINI, D. H.; SCALIVE, R. K. Gestão dE desenvolvimento de produtos: uma referência para melhoria do processo. São Paulo: Saraiva, 2006.

SANTOS, M. R. Design, arte e tecnologia. 2000. Disponível em: <http://www.geocities.com/a_fonte_2000/design.htm>. Acesso em: 20 mai 2006.

SEBRAE. As empresas de menor porte na economia nacional - Alguns indicadores selecionados. Brasília (DF), SEBRAE, 1991.

SEBRAE. Sobrevivência e mortalidade de empresas paulista de 1 a 5 anos. São Paulo, SEBRAESP, 2005. Disponível em: 〈www.sebraesp.com.br>

SEBRAE. Onde estão as micro e pequenas empresas no Brasil. [Marco Aurélio Bedê, coord.] São Paulo, SEBRAE, 2006a.

SEBRAE. Onde estão as micro e pequenas empresas em São Paulo. [Marco Aurélio Bedê, coord.] São Paulo, SEBRAE, 2006b.

SELLTIZ, C. JAHODA, M. DEUTSCH, M. COOK, S.W. Métodos de pesquisa nas relações sociais. Trad. De Dante de Moreira Leite. São Paulo, Editora Pedagógica e Universitária, 1974.

SMETS, G.; OVERBEEK, K. Industrial design engineering and the theory of direct perception. Design Studies Jounal, v. 15, n. 2, p. 175-184, abr. 1994.

SMITH, R. P.; MORROW, J. A. Product development process modeling. Design Studies, v. 20, n. 3, p.237-261, mai. 1999.

SMYTH, S. N.; WALLACE, D.R. Towards the synthesis of aesthetic product form. In: DETC'00 ASME 2000 DESIGN ENGINEERING TECHNICAL CONFERENCES AND COMPUTERS AND INFORMATION IN ENGINEERING CONFERENCE, Baltimore. Proceedings of DETC'00 ASME 2000 Design Engineering Technical Conferences and Computers and Information in Engineering Conference. Baltimore: American Society of Mechanical Engineers, 2000.

SOUZA, P. L. P. Notas para uma história do design. 2. ed. Rio de Janeiro: 2ab Editora, 2000. 89 p.

STAKE, R. Handbook of Qualitative Research. Thousand Oaks: Sage, 1994

STRAUSS, A., CORBIN, J. Basics of qualitative research: grounded thoery procedures and techniques. Newbury Park, Sage, 1990.

SWEDISH INDUSTRIAL DESIGN FOUNDATION (Suécia). About design: the design ladder. Disponível em: <http://www.svid.se/wlt/7FFF9336-1086-4965-8C4F-0CD72E90700B.wlt>. Acesso em: 07 maio 2007. 
SWEDISH INDUSTRIAL DESIGN FOUNDATION; SWEDISH ENGINEERING INDUSTRIES (Suécia). Swedish companies on design - attitudes, profitability and design maturity. 2004. Disponível em: http://www.svid.seand e www.teknikforetagen.se. Acesso em: 30 jun 2007.

TEIXEIRA, J. A. O design estratégico na melhoria da competitividade das empresas. 2005. $270 \mathrm{f}$. Tese (Doutorado) - Programa de Pós-graduação em Engenharia de Produção, Universidade Federal de Santa Catarina, Florianópolis, 2005.

TOVEY, M. Designing with both sides of the brain. Design Studies Journal, v. 5, n. 4, p.219-228, out. 1984.

TOVEY, M. Drawing and CAD in industrial design. Design Studies Journal, v. 10, n. 1, p. 24-39, jan. 1989.

TOVEY, M. Styling and design: intuition and analysis in industrial design. Design Studies Journal, v. 18, n. 1, p.5-31, jan. 1997.

VALERI, S.G. et al. Análise da implementação de um "Gate system" em uma indústria fornecedora do setor automotivo. In: CONGRESSO BRASILEIRO DE GESTÃO DE DESENVOLVIMENTO DE PRODUTO, 2, 2000, São Carlos. Anais do $\mathbf{2}^{\mathbf{0}}$ Congresso Brasileiro de Gestão de Desenvolvimento de Produto. São Carlos: UFSCar, 2000. Disponível em:<http:/ /www.numa.org.br/grupos_numa/grupo_ei /Projetos\% 20EI /Txtei0065.pdf>. Acesso em: 12 set. 2007.

VOSS. C. A. Significant issues for the future of product innovation. Journal of Product Innovation Management, v. 11, n. 5, p.460-463, 1994.

WALLACE, D. R.; JAKIELA, M. J. Automated Product Concept Design: Unifying Aesthetics and Engineering. IEEE Computer Graphics \& Applications, v. 13, n. 4, p.66-75, 1993.

WHYTE, J.; BESSANT, J.; NEELY, A. Management of creativity within the firm. Londres: AIM, 2005

YAMAMOTO, M.; LAMBERT, D. R. The Impact of Product Aesthetics on the Evaluation of Industrial Products. Journal of Product Innovation Management, v. 11, n. 4, p.309-324, 1994.

YIN, R.K. Case study research: design and methods. Applied Social Research Methods Series 5, Sage Publications, 1994

YIN, R. K. The case study crisis: some answers. Administrative Science Quartely, Cornell University, 1981 
ANEXO A

IMAGENS DOS ESTUDOS DE CASO 


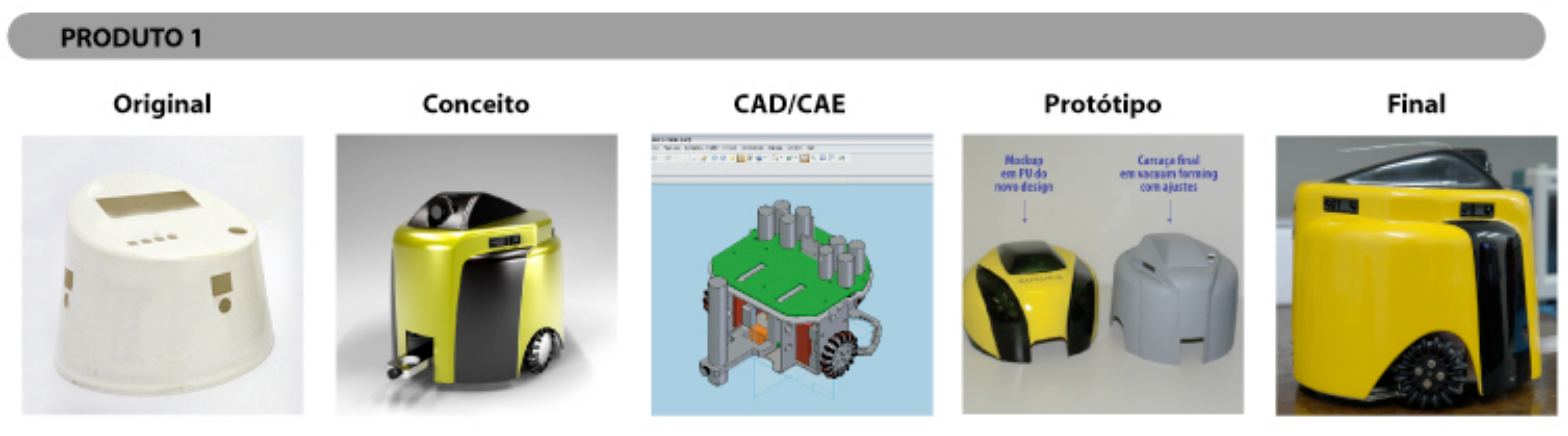

\section{PRODUTO 2}
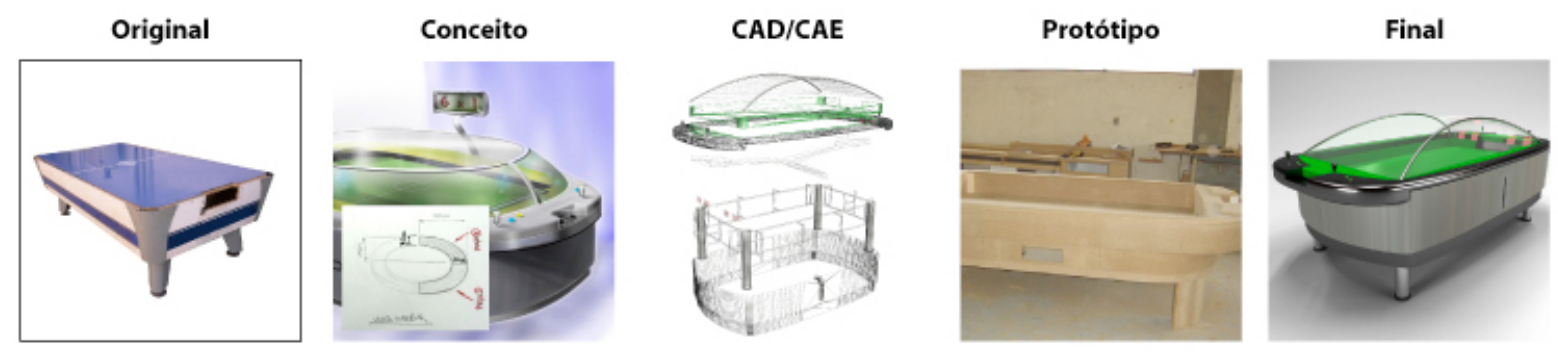

PRODUTO 3
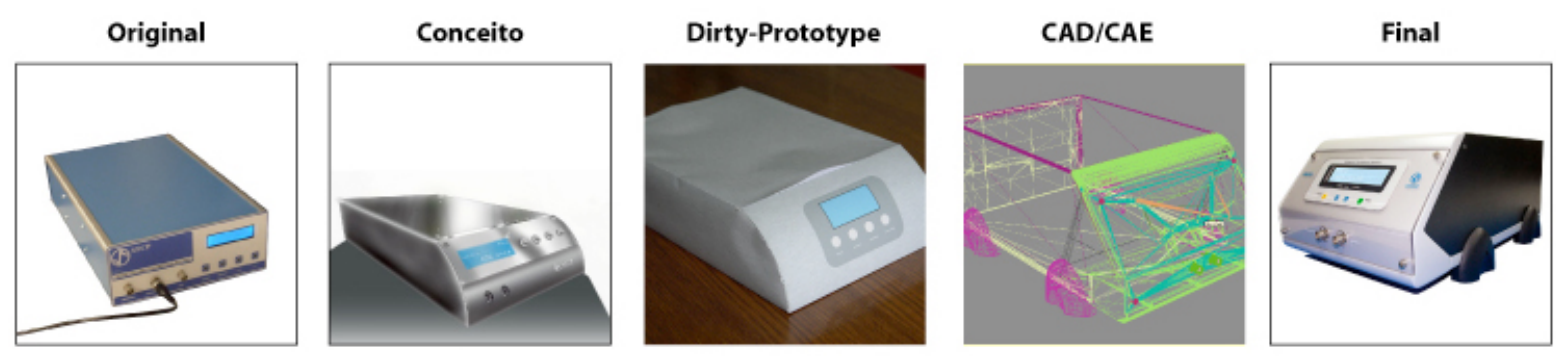

\section{PRODUTO 4}
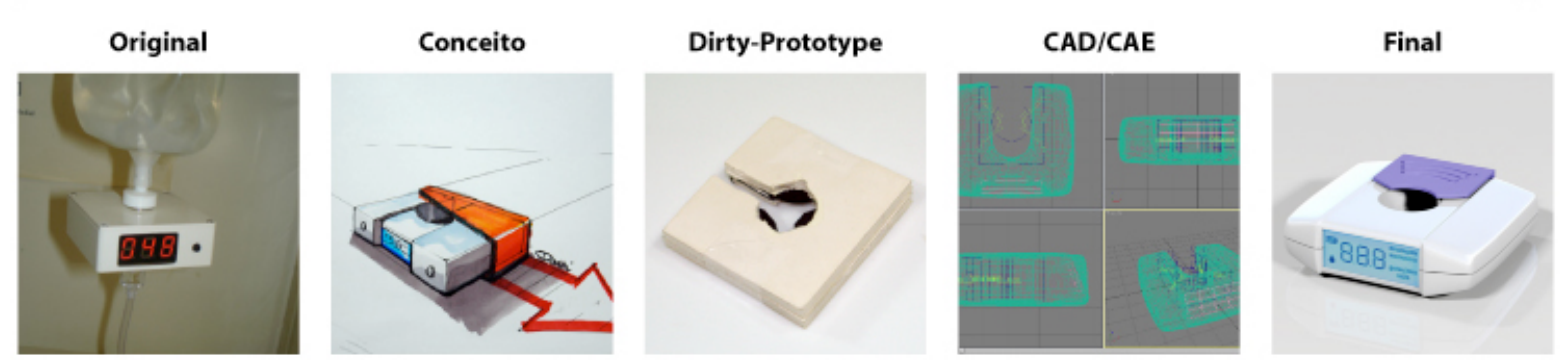

\section{PRODUTO 5}
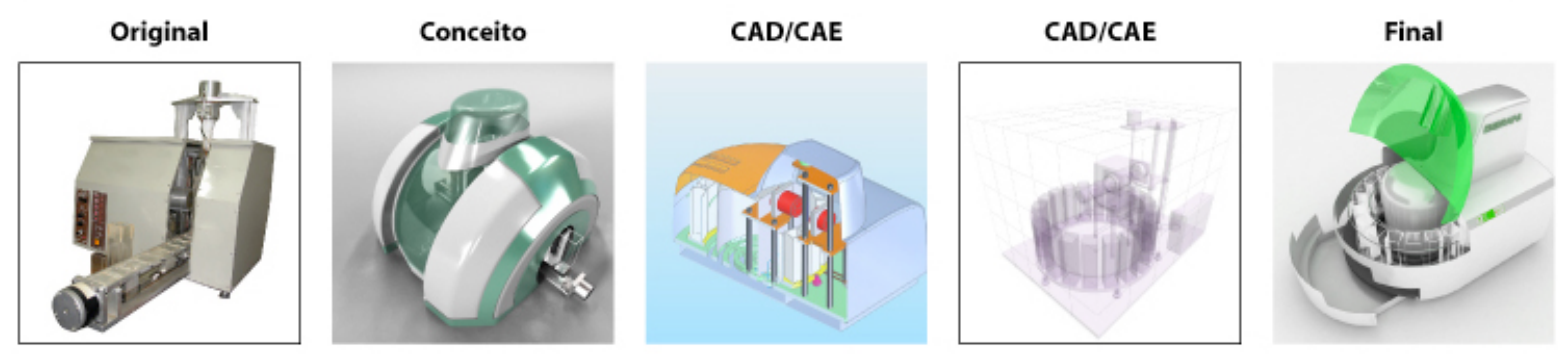


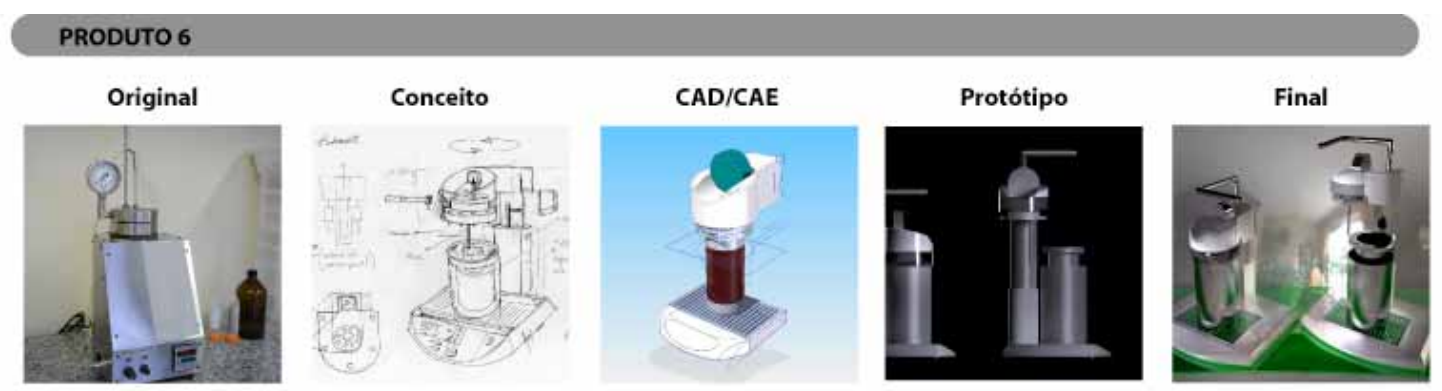

PRODUTO 7
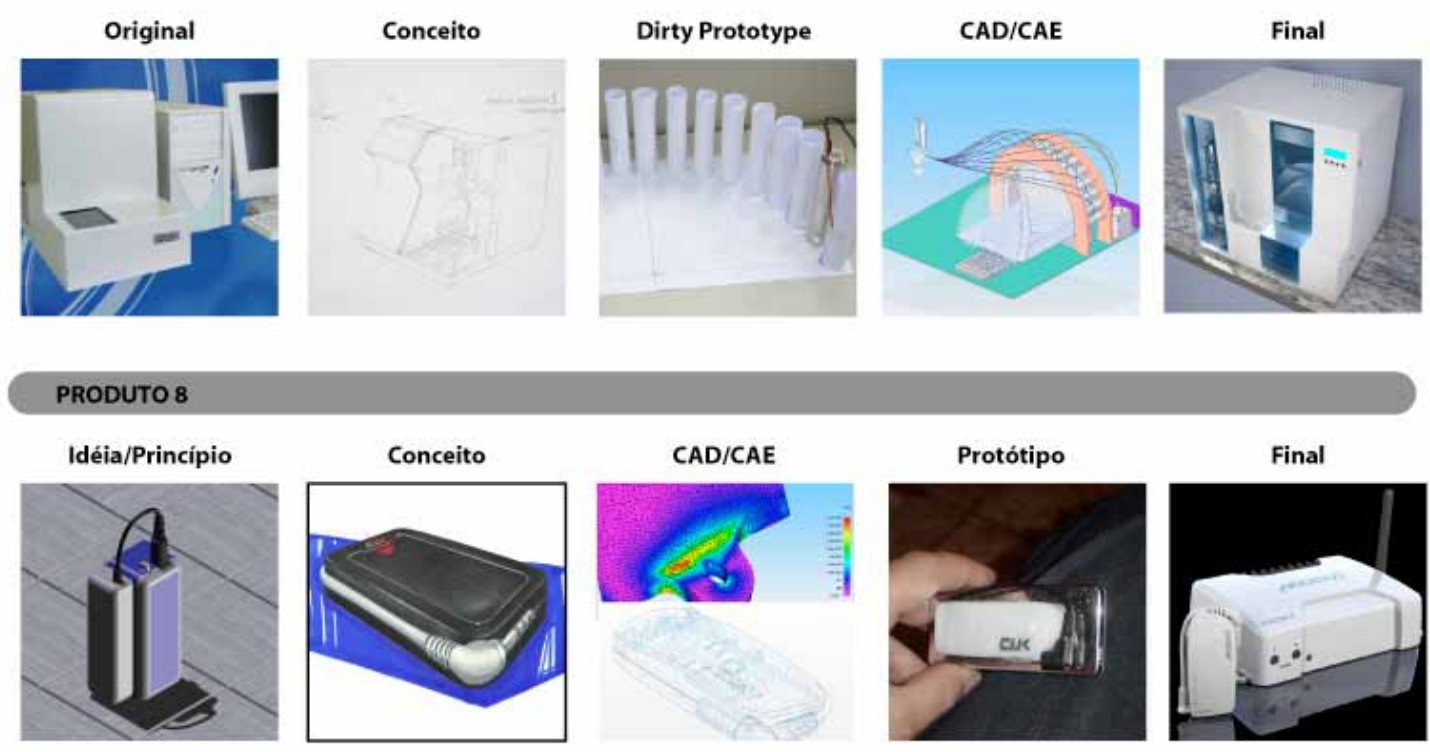

\section{PRODUTO 9}
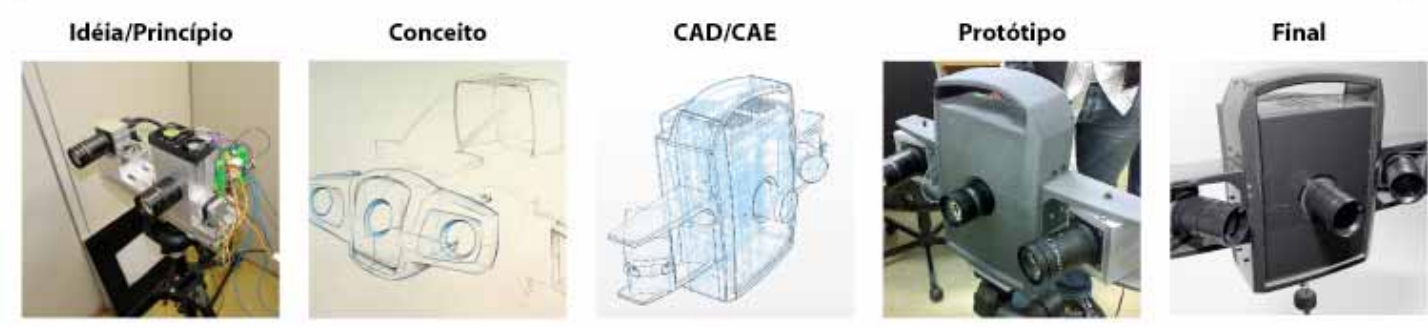

\section{PRODUTO 10}
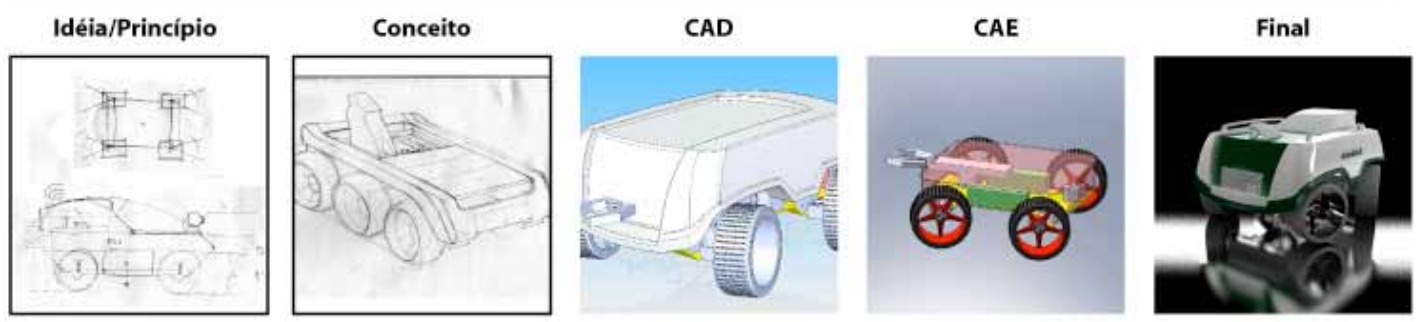
APÊNDICE A

PLANILHAS DA "FERRAMENTA DE AUDITORIA DO PRODUTO” 
As planilhas abaixo apresentadas constituíram a "Ferramenta de Auditoria de Produto", utilizada neste trabalho. Foram traduzidas e adaptadas pelo autor a partir da ferramenta original "Design Audit Tool", apresentada no workbook Assessing and improving product design capability (MOULTRIE e FRASER, 2004, p.03-28), como um resultado do programa Good Design Pratice do Institute for Manufaturing (IfM) e Engineering Design Centre - ambos do Departamento de Engenharia da Universidade de Cambridge - e Industrial Design Engineering Group do Royal College of Art - ambas universidades do Reino Unido.

\begin{tabular}{|c|c|c|c|c|c|c|}
\hline \multicolumn{6}{|c|}{ Benefícios centrais... } & \multirow{2}{*}{$\begin{array}{l}\text { Produto } \\
\text { Excelente Performance }\end{array}$} \\
\hline Questão & Baixa Performance & \multicolumn{4}{|c|}{ Pontuação } & \\
\hline Necessidade & $\begin{array}{r}\text { Porque eu precisaria disto ? - } \\
\text { Não é óbvio quais benefícios o } \\
\text { público-alvo ganharia com a } \\
\text { utilização }\end{array}$ & 1 & 2 & 3 & 4 & $\begin{array}{l}\text { Benefícios óbvios - Salvará } \\
\text { tempo, dinheiro ou esforço do } \\
\text { público-alvo e é } \\
\text { absolutamente essencial }\end{array}$ \\
\hline Funcionalidade & $\begin{array}{l}\text { Funcionalidade demais ou de } \\
\text { menos para ser realmente útil }\end{array}$ & 1 & 2 & 3 & 4 & $\begin{array}{l}\text { Nível apropriado de } \\
\text { funcionalidade - e nada mais }\end{array}$ \\
\hline Alternativas & $\begin{array}{r}\text { Muitas alternativas por aí fazem } \\
\text { a mesma função - muitas vezes } \\
\text { melhor }\end{array}$ & 1 & 2 & 3 & 4 & $\begin{array}{l}\text { Não há uma alternativas } \\
\text { viáveis para este produto - } \\
\text { com a mesma capacidade }\end{array}$ \\
\hline \multirow[t]{2}{*}{ Valor } & $\begin{array}{r}\text { Compraria se fosse realmente } \\
\text { preciso - mas pagaria } \\
\text { absolutamente o mínimo }\end{array}$ & 1 & 2 & 3 & 4 & $\begin{array}{l}\text { Pagaria um preço Premium - } \\
\text { mesmo que não precisasse } \\
\text { realmente }\end{array}$ \\
\hline & Poucos benefícios reais & 1 & 2 & 3 & 4 & Benefícios relevantes \\
\hline
\end{tabular}

\begin{tabular}{|c|r|c|c|c|c|c|c|}
\hline Qualidade de Engenharia... \\
\hline Questão & Baixa Performance & \multicolumn{3}{|c|}{ Pontuação } & Excelente Performance \\
\hline Performance & $\begin{array}{r}\text { Promessas demais e } \\
\text { performance de menos }\end{array}$ & 1 & 2 & 3 & 4 & $\begin{array}{l}\text { Performance excede } \\
\text { expectativas }\end{array}$ \\
\hline Confiabilidade & $\begin{array}{r}\text { Não-confiável - falha } \\
\text { regularmente em trabalhar } \\
\text { corretamente }\end{array}$ & 1 & 2 & 3 & 4 & $\begin{array}{l}\text { Um cavalo de trabalho - 100\% } \\
\text { confiável }\end{array}$ \\
\hline $\begin{array}{r}\text { Qualidade de } \\
\text { Construção }\end{array}$ & $\begin{array}{r}\text { Construção pobre - parece-se e } \\
\text { percebe-se como barato }\end{array}$ & 1 & 2 & 3 & 4 & $\begin{array}{l}\text { Construído solidamente e } \\
\text { com boa engenharia }\end{array}$ \\
\hline Durabilidade & $\begin{array}{r}\text { Durabilidade pobre - tendência a } \\
\text { quebrar ou parar de trabalhar }\end{array}$ & 1 & 2 & 3 & 4 & $\begin{array}{l}110 \% \text { durável - irá superar a } \\
\text { concorrência }\end{array}$ \\
\hline & $\begin{array}{r}\text { Qualidade de engenharia } \\
\text { pobre - geral }\end{array}$ & $\mathbf{1}$ & $\mathbf{2}$ & $\mathbf{3}$ & $\mathbf{4}$ & $\begin{array}{l}\text { Qualidade de engenharia } \\
\text { excelente - geral }\end{array}$ \\
\hline
\end{tabular}




\begin{tabular}{|c|c|c|c|c|c|c|}
\hline \multicolumn{6}{|c|}{ Usabilidade... } & \multirow{2}{*}{$\begin{array}{l}\text { Produto } \\
\text { Excelente Performance }\end{array}$} \\
\hline Questão & Baixa Performance & & ont & uaçã & & \\
\hline \multirow{3}{*}{ Iniciando o uso } & $\begin{array}{r}\text { Embalagem pobre - difícil de } \\
\text { acessar, desperdício de } \\
\text { materiais e gráficos/instruções } \\
\text { confusas }\end{array}$ & 1 & 2 & 3 & 4 & $\begin{array}{l}\text { Embalagem excelente - acesso } \\
\text { fácil, excelência no projeto, } \\
\text { acesso óbvio }\end{array}$ \\
\hline & $\begin{array}{r}\text { Necessita diversas semanas de } \\
\text { treinamento apenas para } \\
\text { começar }\end{array}$ & 1 & 2 & 3 & 4 & $\begin{array}{l}\text { Treinamento não é necessário } \\
\text { ou é bem oferecido }\end{array}$ \\
\hline & $\begin{array}{r}\text { Manual de instruções e/ou } \\
\text { documentação próximos do } \\
\text { inútil }\end{array}$ & 1 & 2 & 3 & 4 & $\begin{array}{l}\text { Documentação de suporte é } \\
\text { clara, concisa e útil }\end{array}$ \\
\hline \multirow{7}{*}{$\begin{array}{l}\text { Inteligibilidade } \\
\text { de Interface }\end{array}$} & $\begin{array}{l}\text { Interface com o usuário ignora } \\
\text { regras aceitas e convenções }\end{array}$ & 1 & 2 & 3 & 4 & $\begin{array}{l}\text { Interface segue (ou melhora) } \\
\text { regras aceitas e convenções - } \\
\text { é compatível com } \\
\text { equipamentos similares }\end{array}$ \\
\hline & $\begin{array}{r}\text { Baixa hierarquização da } \\
\text { informação ou priorização de } \\
\text { funções }\end{array}$ & 1 & 2 & 3 & 4 & $\begin{array}{l}\text { As funções/informações mais } \\
\text { importantes são as mais } \\
\text { acessíveis e as mais } \\
\text { claramente priorizadas }\end{array}$ \\
\hline & $\begin{array}{l}\text { Erros frequentes e } \\
\text { irrecuperáveis }\end{array}$ & 1 & 2 & 3 & 4 & $\begin{array}{l}\text { Pouca possibilidade de erros - } \\
\text { quando acontecem, a } \\
\text { recuperação é fácil }\end{array}$ \\
\hline & $\begin{array}{r}\text { Pouco ou nenhum feedback } \\
\text { entre ação e efeito }\end{array}$ & 1 & 2 & 3 & 4 & $\begin{array}{l}\text { Feedback claro e óbvio informa } \\
\text { quando ações são executadas }\end{array}$ \\
\hline & $\begin{array}{r}\text { Pouco ou nenhum mapeamento } \\
\text { natural entre controles e ações } \\
\text { resultantes }\end{array}$ & 1 & 2 & 3 & 4 & $\begin{array}{l}\text { Mapeamento natural claro e } \\
\text { óbvio entre controles e ações } \\
\text { resultantes }\end{array}$ \\
\hline & $\begin{array}{r}\text { Poucas restrições projetadas } \\
\text { para prevenir erros ou orientar } \\
\text { ações }\end{array}$ & 1 & 2 & 3 & 4 & $\begin{array}{l}\text { Restrições apropriadamente } \\
\text { projetadas para prevenir erros } \\
\text { e orientar ações }\end{array}$ \\
\hline & $\begin{array}{r}\text { Impossibilidade da interface ser } \\
\text { compreendida pela maioria da } \\
\text { população-alvo }\end{array}$ & 1 & 2 & 3 & 4 & $\begin{array}{l}\text { Interface será entendida tanto } \\
\text { pelo alvo quando pela } \\
\text { população em geral }\end{array}$ \\
\hline \multirow{2}{*}{$\begin{array}{l}\text { Usabilidade } \\
\text { Física }\end{array}$} & $\begin{array}{r}\text { Elementos físicos tem o } \\
\text { tamanho, a forma e a disposição } \\
\text { errados para serem utilizados } \\
\text { confortavelmente }\end{array}$ & 1 & 2 & 3 & 4 & $\begin{array}{l}\text { Todos os elementos tem o } \\
\text { tamanho, a forma e a } \\
\text { disposição para os usuários da } \\
\text { população-alvo }\end{array}$ \\
\hline & $\begin{array}{r}\text { Tamanho, forma e posição dos } \\
\text { elementos não podem ser } \\
\text { ajustados para as necessidades } \\
\text { de usuários diferentes }\end{array}$ & 1 & 2 & 3 & 4 & $\begin{array}{l}\text { Todos os ajustes necessários } \\
\text { estão disponíveis para tal }\end{array}$ \\
\hline \multirow{3}{*}{$\begin{array}{l}\text { Manutenção e } \\
\text { Limpeza }\end{array}$} & $\begin{array}{r}\text { Dificuldade de abastecer, } \\
\text { manter e consertar }\end{array}$ & 1 & 2 & 3 & 4 & $\begin{array}{l}\text { Abastecimentos, manutenção e } \\
\text { conserto são ou simples ou } \\
\text { não necessários }\end{array}$ \\
\hline & $\begin{array}{r}\text { Difícil de limpar - entradas, } \\
\text { ranhuras e áreas de difícil } \\
\text { acesso ou materiais facilmente } \\
\text { danificáveis }\end{array}$ & 1 & 2 & 3 & 4 & $\begin{array}{l}\text { Fácil de limpar - materiais } \\
\text { apropriados, acesso fácil, } \\
\text { superfícies suaves, boa } \\
\text { visibilidade }\end{array}$ \\
\hline & Baixa performance geral & 1 & 2 & 3 & 4 & Excelente usabilidade geral \\
\hline
\end{tabular}




\begin{tabular}{|c|c|c|c|c|c|c|}
\hline \multicolumn{6}{|c|}{ Desejabilidade... } & \multirow{2}{*}{$\begin{array}{l}\text { Produto } \\
\text { Excelente Performance }\end{array}$} \\
\hline Questão & Baixa Performance & & ontc & Iaçá & & \\
\hline \multirow{4}{*}{ Estética } & $\begin{array}{r}\text { Sem novidade visual - parece } \\
\text { com todo o resto }\end{array}$ & 1 & 2 & 3 & 4 & $\begin{array}{l}\text { Estética nova dá uma } \\
\text { identidade forte - visualmente } \\
\text { diferenciada da concorrência }\end{array}$ \\
\hline & $\begin{array}{r}\text { Nenhum ou muito contraste } \\
\text { entre elementos - tom, forma, } \\
\text { cor, linhas }\end{array}$ & 1 & 2 & 3 & 4 & $\begin{array}{l}\text { Exatamente a quantidade } \\
\text { certa de contraste entre os } \\
\text { elementos - tom, forma, cor, } \\
\text { linhas }\end{array}$ \\
\hline & $\begin{array}{l}\text { Nenhum senso de ordem no } \\
\text { design - uma coleção incoerente } \\
\text { e não-harmoniosa de elementos }\end{array}$ & 1 & 2 & 3 & 4 & $\begin{array}{l}\text { Um alto senso de ordem - } \\
\text { uma harmonia prazerosa de } \\
\text { formas, materiais, } \\
\text { acabamentos, cores e } \\
\text { estruturas }\end{array}$ \\
\hline & $\begin{array}{r}\text { Sua aparência é inapropriada e } \\
\text { não faz sentido - Apenas parece } \\
\text { errado ! }\end{array}$ & 1 & 2 & 3 & 4 & $\begin{array}{l}\text { Sua aparência faz completo } \\
\text { sentido - Apenas parece certo } \\
!\end{array}$ \\
\hline \multirow{3}{*}{$\begin{array}{c}\text { Simbolismo e } \\
\text { Status }\end{array}$} & $\begin{array}{l}\text { A propriedade tem nenhum (ou } \\
\text { negativo) impacto no status } \\
\text { perante os pares do público-alvo }\end{array}$ & 1 & 2 & 3 & 4 & $\begin{array}{l}\text { A propriedade melhora o } \\
\text { status entre os pares do } \\
\text { público-alvo }\end{array}$ \\
\hline & $\begin{array}{r}\text { Não representa ou expressa os } \\
\text { gostos ou valores do seu } \\
\text { público-alvo }\end{array}$ & 1 & 2 & 3 & 4 & $\begin{array}{l}\text { Simboliza ou expressa } \\
\text { precisamente os valores, } \\
\text { crenças e gostos do seu } \\
\text { público-alvo }\end{array}$ \\
\hline & $\begin{array}{r}\text { Aparência é inapropriada para o } \\
\text { contexto ou ambiente de uso }\end{array}$ & 1 & 2 & 3 & 4 & $\begin{array}{l}\text { Aparência é apropriada para o } \\
\text { contexto pretendido ou } \\
\text { ambiente de uso }\end{array}$ \\
\hline \multirow{3}{*}{$\begin{array}{c}\text { Inteligibilidade } \\
\text { Visual }\end{array}$} & $\begin{array}{r}\text { Nenhuma identidade de marca } \\
\text { clara ou coerente através da } \\
\text { gama de produtos }\end{array}$ & 1 & 2 & 3 & 4 & $\begin{array}{l}\text { Design reforça e reflete os } \\
\text { valores e identidade da marca } \\
\text { da empresa }\end{array}$ \\
\hline & $\begin{array}{r}\text { Aparência é inconsistente com } \\
\text { valores esperados - ex. Forte, } \\
\text { precioso, divertido, etc. }\end{array}$ & 1 & 2 & 3 & 4 & $\begin{array}{l}\text { Design expressa e reforça } \\
\text { valores e qualidade } \\
\text { específicas - ex. rápido, } \\
\text { preciso, forte, etc. }\end{array}$ \\
\hline & $\begin{array}{r}\text { Aparência confusa que fornece } \\
\text { poucas pistas para descrever o } \\
\text { propósito e uso do produto }\end{array}$ & 1 & 2 & 3 & 4 & $\begin{array}{l}\text { Aparência ajuda a descrever } \\
\text { claramente o propósito, } \\
\text { função e operação do produto }\end{array}$ \\
\hline $\begin{array}{l}\text { Todos os } \\
\text { Sentidos }\end{array}$ & $\begin{array}{r}\text { É "sentido", cheira e tem som } \\
\text { horríveis - pouco prazer } \\
\text { sensorial (toque, feel, etc) }\end{array}$ & 1 & 2 & 3 & 4 & $\begin{array}{l}\text { É "sentido" tão bem quanto } \\
\text { aparenta: prazer sensual } \\
\text { através do conforto, material } \\
\text { ou textura }\end{array}$ \\
\hline Orgulho & $\begin{array}{r}\text { Pouco orgulha na propriedade; } \\
\text { design é utilitário e funcional - } \\
\text { para ser escondido }\end{array}$ & 1 & 2 & 3 & 4 & $\begin{array}{l}\text { Design inspira um sentimento } \\
\text { de orgulho em comprar e } \\
\text { possuir - para ser exibido }\end{array}$ \\
\hline \multirow[t]{2}{*}{$\begin{array}{l}\text { Resposta } \\
\text { Emocional }\end{array}$} & $\begin{array}{r}\text { O produto produz uma resposta } \\
\text { emocional negativa - faz sentir } \\
\text { confuso, frustrado, raivoso, } \\
\text { preocupado, etc. }\end{array}$ & 1 & 2 & 3 & 4 & $\begin{array}{l}\text { O produto produz uma } \\
\text { resposta emocional positiva - } \\
\text { faz sentir feliz, satisfeito, } \\
\text { restaurado, etc. }\end{array}$ \\
\hline & Baixa desejabilidade geral & 1 & 2 & 3 & 4 & Alta desejabilidade geral \\
\hline
\end{tabular}




\begin{tabular}{|c|c|c|c|c|c|c|}
\hline \multicolumn{6}{|c|}{ Produtibilidade... } & \multirow{2}{*}{$\begin{array}{l}\text { Produto } \\
\text { Excelente Performance }\end{array}$} \\
\hline Questão & Baixa Performance & \multicolumn{4}{|c|}{ Pontuação } & \\
\hline \multirow{3}{*}{$\begin{array}{l}\text { Manufatura de } \\
\text { Componentes }\end{array}$} & $\begin{array}{r}\text { Peças demais - "over } \\
\text { engineered" }\end{array}$ & 1 & 2 & 3 & 4 & $\begin{array}{l}\text { Nível ótimo de peças - cada } \\
\text { uma explica sua razão para } \\
\text { estar lá }\end{array}$ \\
\hline & $\begin{array}{r}\text { Muitos componentes } \\
\text { "problemáticos" são difíceis de } \\
\text { produzir - muito resíduo e re- } \\
\text { trabalho }\end{array}$ & 1 & 2 & 3 & 4 & $\begin{array}{l}\text { Nenhum componente } \\
\text { "problemático" e também pouco } \\
\text { resíduo e re-trabalho - todos } \\
\text { componentes são simples de } \\
\text { produzir }\end{array}$ \\
\hline & $\begin{array}{r}\text { Nenhum senso de ordem no } \\
\text { design - uma coleção } \\
\text { incoerente e não-harmoniosa de } \\
\text { elementos }\end{array}$ & 1 & 2 & 3 & 4 & $\begin{array}{l}\text { Um alto senso de ordem - uma } \\
\text { harmonia prazerosa de formas, } \\
\text { materiais, acabamentos, cores } \\
\text { e estruturas }\end{array}$ \\
\hline \multirow{8}{*}{$\begin{array}{l}\text { Montagem e } \\
\text { Teste }\end{array}$} & $\begin{array}{r}\text { Montagem necessita de pessoal } \\
\text { altamente qualificada - uma } \\
\text { "arte negra" }\end{array}$ & 1 & 2 & 3 & 4 & $\begin{array}{l}\text { Montagem simples com treino } \\
\text { mínimo }\end{array}$ \\
\hline & Exigência de testes extensos & 1 & 2 & 3 & 4 & $\begin{array}{l}\text { Projetados para minimizar a } \\
\text { necessidade de testes em } \\
\text { produção }\end{array}$ \\
\hline & $\begin{array}{r}\text { Prendedores demais - tipos e } \\
\text { tamanhos diferentes }\end{array}$ & 1 & 2 & 3 & 4 & $\begin{array}{l}\text { Poucos prendedores - todos } \\
\text { justificados }\end{array}$ \\
\hline & $\begin{array}{l}\text { Necessidade de montagem e } \\
\text { equipamento de teste especiais }\end{array}$ & 1 & 2 & 3 & 4 & $\begin{array}{l}\text { Ferramental mínimo com } \\
\text { poucas (se alguma...) } \\
\text { ferramentas especiais }\end{array}$ \\
\hline & $\begin{array}{r}\text { Montagem a partir de muitas } \\
\text { direções, com acesso pobre } \\
\text { para inserir e fixar }\end{array}$ & 1 & 2 & 3 & 4 & $\begin{array}{l}\text { Montagem simples a partir de } \\
\text { uma única direção } \\
\text { (preferencialmente) com } \\
\text { acesso aberto }\end{array}$ \\
\hline & $\begin{array}{r}\text { Diversos componentes "difíceis } \\
\text { para lidar" }\end{array}$ & 1 & 2 & 3 & 4 & $\begin{array}{l}\text { Sem dificuldades de } \\
\text { manipulação de componentes }\end{array}$ \\
\hline & $\begin{array}{r}\text { Uma bagunça confusa de fios e } \\
\text { cabos }\end{array}$ & 1 & 2 & 3 & 4 & $\begin{array}{l}\text { Cabos e fios minimizados - e } \\
\text { organizados simplesmente } \\
\text { quando necessários }\end{array}$ \\
\hline & $\begin{array}{r}\text { Necessidade de muitos ajustes } \\
\text { e configuração }\end{array}$ & 1 & 2 & 3 & 4 & $\begin{array}{l}\text { Projetado para minimizar a } \\
\text { necessidade de ajustes e } \\
\text { configuração }\end{array}$ \\
\hline \multirow[t]{2}{*}{$\begin{array}{l}\text { Estratégia de } \\
\text { Plataforma }\end{array}$} & $\begin{array}{r}\text { Sem estratégia de plataforma } \\
\text { de produto, com cada produto } \\
\text { utilizando módulos, } \\
\text { componentes e produção } \\
\text { diferentes }\end{array}$ & 1 & 2 & 3 & 4 & $\begin{array}{l}\text { Plataforma de produtos } \\
\text { definidas com um alto nível de } \\
\text { reuso de módulos, } \\
\text { componentes e processos entre } \\
\text { os produtos }\end{array}$ \\
\hline & Baixa produtibilidade geral & 1 & 2 & 3 & 4 & Boa produtibilidade geral \\
\hline
\end{tabular}




\begin{tabular}{|c|c|c|c|c|c|c|}
\hline \multicolumn{6}{|c|}{ Lucratividade... } & \multirow{3}{*}{\begin{tabular}{|l} 
Produto \\
Excelente Performance \\
Entrada excede expectativas
\end{tabular}} \\
\hline \multirow{2}{*}{$\begin{array}{l}\text { Questão } \\
\text { Entrada }\end{array}$} & \multirow{2}{*}{$\begin{array}{c}\text { Baixa Performance } \\
\text { Menor entrada do que planejado }\end{array}$} & \multicolumn{4}{|c|}{ Pontuação } & \\
\hline & & 1 & 2 & 3 & 4 & \\
\hline $\begin{array}{l}\text { Custos de } \\
\text { Produção }\end{array}$ & Custo da unidade muito alto & 1 & 2 & 3 & 4 & $\begin{array}{l}\text { Custo da unidade mais baixo } \\
\text { do que o esperado }\end{array}$ \\
\hline $\begin{array}{l}\text { Vendas e } \\
\text { Custos de } \\
\text { Assistência }\end{array}$ & $\begin{array}{r}\text { Custa demais para vender e dar } \\
\text { assistência }\end{array}$ & 1 & 2 & 3 & 4 & $\begin{array}{l}\text { Vender e dar assistência custa } \\
\text { menos do que o esperado }\end{array}$ \\
\hline $\begin{array}{l}\text { Lucro (por } \\
\text { unidade) }\end{array}$ & Margens estão muito baixas & 1 & 2 & 3 & 4 & $\begin{array}{l}\text { Margens excedem } \\
\text { expectativas }\end{array}$ \\
\hline \multirow[t]{2}{*}{$\begin{array}{l}\text { Fatia de } \\
\text { Mercado }\end{array}$} & $\begin{array}{r}\text { Pequena fatia de mercado em } \\
\text { encolhimento }\end{array}$ & 1 & 2 & 3 & 4 & $\begin{array}{l}\text { Boa fatia de mercado em } \\
\text { expansão }\end{array}$ \\
\hline & Pobre lucratividade geral & 1 & 2 & 3 & 4 & Boa lucratividade geral \\
\hline
\end{tabular}




\begin{tabular}{|c|c|c|c|c|c|c|}
\hline \multicolumn{6}{|c|}{ Novidade e Diferenciação... } & \multirow{2}{*}{\begin{tabular}{|l|} 
Produto \\
Excelente Performance
\end{tabular}} \\
\hline Questão & Baixa Performance & \multicolumn{4}{|c|}{ Pontuação } & \\
\hline $\begin{array}{l}\text { Benefícios } \\
\text { centrais }\end{array}$ & $\begin{array}{r}\text { Sem diferenciação clara - } \\
\text { produto genérico com atributos } \\
\text { padrão }\end{array}$ & 1 & 2 & 3 & 4 & $\begin{array}{l}\text { Oferta claramente } \\
\text { diferenciada - benefícios } \\
\text { únicos }\end{array}$ \\
\hline $\begin{array}{l}\text { Funções e } \\
\text { atributos }\end{array}$ & $\begin{array}{l}\text { Produto "eu-também" - atributos } \\
\text { padrão pelo preço padrão }\end{array}$ & 1 & 2 & 3 & 4 & $\begin{array}{l}\text { Solução radical que aborda o } \\
\text { problema de forma nova e } \\
\text { interessante }\end{array}$ \\
\hline Tecnologia & $\begin{array}{r}\text { Tecnologia de ontem - não é um } \\
\text { diferenciador }\end{array}$ & 1 & 2 & 3 & 4 & $\begin{array}{l}\text { Original / tecnologia de } \\
\text { ruptura - inovará e mudará o } \\
\text { mercado - um diferenciador }\end{array}$ \\
\hline $\begin{array}{l}\text { Qualidade } \\
\text { Técnica }\end{array}$ & $\begin{array}{r}\text { A qualidade de engenharia não } \\
\text { oferece diferenciação - robustez, } \\
\text { confiabilidade ou acesso aos } \\
\text { serviços, etc }\end{array}$ & 1 & 2 & 3 & 4 & $\begin{array}{l}\text { A qualidade de engenharia é } \\
\text { um diferenciador principal - } \\
\text { robustez, confiabilidade ou } \\
\text { acesso aos serviços, etc }\end{array}$ \\
\hline Estética & $\begin{array}{r}\text { Visualmente mediano - não é um } \\
\text { diferenciador }\end{array}$ & 1 & 2 & 3 & 4 & $\begin{array}{l}\text { Estética original - um } \\
\text { diferenciador principal }\end{array}$ \\
\hline Usabilidade & $\begin{array}{r}\text { Controles e interface com o } \\
\text { usuário padrões - não é um } \\
\text { diferenciador }\end{array}$ & 1 & 2 & 3 & 4 & $\begin{array}{l}\text { Altamente "utilizável" e } \\
\text { inclusivo - um diferenciador } \\
\text { principal }\end{array}$ \\
\hline Marca & $\begin{array}{r}\text { Baixo valor de marca - não é um } \\
\text { diferenciador }\end{array}$ & 1 & 2 & 3 & 4 & $\begin{array}{l}\text { Presença forte e original da } \\
\text { marca - um diferenciador } \\
\text { principal }\end{array}$ \\
\hline Pós-Venda & $\begin{array}{r}\text { Treinamento, serviço, assistência } \\
\text { e manutenção não são } \\
\text { diferenciadores }\end{array}$ & 1 & 2 & 3 & 4 & $\begin{array}{l}\text { Pós-venda oferece } \\
\text { diferenciação única }\end{array}$ \\
\hline $\begin{array}{c}\text { Financiamento e } \\
\text { Garantia }\end{array}$ & $\begin{array}{r}\text { Nenhuma diferenciação pela } \\
\text { garantia e financiamento }\end{array}$ & 1 & 2 & 3 & 4 & $\begin{array}{l}\text { Condições de financiamento } \\
\text { ou garantia oferece } \\
\text { diferenciação }\end{array}$ \\
\hline Entrega & $\begin{array}{r}\text { Nenhuma diferenciação através } \\
\text { da entrega }\end{array}$ & 1 & 2 & 3 & 4 & $\begin{array}{l}\text { Capacidade de entrega } \\
\text { oferece diferenciação real }\end{array}$ \\
\hline $\begin{array}{l}\text { Outras } \\
\text { qualidades }\end{array}$ & Sem diferenciação ou novidade & 1 & 2 & 3 & 4 & Abordagem original \\
\hline $\begin{array}{l}\text { Benefícios } \\
\text { centrais }\end{array}$ & Sem diferenciação ou novidade & 1 & 2 & 3 & 4 & Abordagem original \\
\hline \multirow[t]{2}{*}{$\begin{array}{l}\text { Benefícios } \\
\text { centrais }\end{array}$} & Sem diferenciação ou novidade & 1 & 2 & 3 & 4 & Abordagem original \\
\hline & $\begin{array}{r}\text { Novidade e diferenciação geral } \\
\text { pobre }\end{array}$ & 1 & 2 & 3 & 4 & $\begin{array}{l}\text { Novidade e diferenciação } \\
\text { geral boa }\end{array}$ \\
\hline
\end{tabular}




\begin{tabular}{|c|c|c|c|c|c|c|}
\hline \multicolumn{6}{|c|}{ Resumo da Auditoria do Produto } & \multirow[t]{2}{*}{ Produto } \\
\hline \multicolumn{6}{|c|}{ Performance do Produto } & \\
\hline Questão & Baixa Performance & \multicolumn{4}{|c|}{ Pontuação } & Excelente Performance \\
\hline Produtibilidade & Produtibilidade geral pobre & 1 & 2 & 3 & 4 & Produtibilidade geral boa \\
\hline Lucratividade & Lucratividade geral pobre & 1 & 2 & 3 & 4 & Lucratividade geral boa \\
\hline $\begin{array}{l}\text { Benefícios } \\
\text { Centrais }\end{array}$ & Poucos benefícios reais & 1 & 2 & 3 & 4 & Benefícios gerais relevantes \\
\hline $\begin{array}{l}\text { Qualidade de } \\
\text { Engenharia }\end{array}$ & $\begin{array}{r}\text { Qualidade de engenharia geral } \\
\text { pobre }\end{array}$ & 1 & 2 & 3 & 4 & $\begin{array}{l}\text { Qualidade de engenharia } \\
\text { geral excelente }\end{array}$ \\
\hline Usabilidade & Usabilidade geral pobre & 1 & 2 & 3 & 4 & Usabilidade geral boa \\
\hline Desejabilidade & Desejabilidade geral baixa & 1 & 2 & 3 & 4 & Desejabilidade geral alta \\
\hline Novidade & Pouca novidade geral & 1 & 2 & 3 & 4 & Boa novidade geral \\
\hline \multicolumn{7}{|l|}{$\begin{array}{l}\text { Diferenciadores } \\
\text { principais } \\
\text { oferecidos... }\end{array}$} \\
\hline \multicolumn{7}{|c|}{ I mportância para os Usuários/ Consumidores } \\
\hline $\begin{array}{l}\text { Benefícios } \\
\text { Centrais }\end{array}$ & Poucos benefícios reais gerais & 1 & 2 & 3 & 4 & Benefícios gerais relevantes \\
\hline $\begin{array}{l}\text { Qualidade de } \\
\text { Engenharia }\end{array}$ & $\begin{array}{l}\text { Qualidade de engenharia geral } \\
\text { não é importante }\end{array}$ & 1 & 2 & 3 & 4 & $\begin{array}{l}\text { Qualidade de engenharia } \\
\text { geral importante }\end{array}$ \\
\hline Usabilidade & Usabilidade não é importante & 1 & 2 & 3 & 4 & Usabilidade muito importante \\
\hline Desejabilidade & Desejabilidade não é importante & 1 & 2 & 3 & 4 & $\begin{array}{l}\text { Desejabilidade é muito } \\
\text { importante }\end{array}$ \\
\hline Novidade & Novidade não é importante & 1 & 2 & 3 & 4 & Novidade é muito importante \\
\hline $\begin{array}{l}\text { Diferenciadores } \\
\text { principais } \\
\text { requisitados... }\end{array}$ & & & & & & \\
\hline
\end{tabular}

